\title{
Lewis Base-Catalyzed Amino-Acylation of Arylallenes via C-N Bond Cleavage: Reaction Development and Mechanistic Studies
}

Zheng-Bing Zhang, ${ }^{\text {acc }}$ Yusheng Yang, ${ }^{\text {b }}$ Zhi-Xiang Yu ${ }^{*, b}$ and Ji-Bao Xia*,a,c

\begin{abstract}
a State Key Laboratory for Oxo Synthesis and Selective Oxidation, Center for Excellence in Molecular Synthesis, Suzhou Research Institute of LICP, Lanzhou Institute of Chemical Physics (LICP), University of Chinese Academy of Sciences, Chinese Academy of Sciences, Lanzhou 730000, China

b Beijing National Laboratory for Molecular Sciences (BNLMS), Key Laboratory of Bioorganic Chemistry and Molecular Engineering of Ministry of Education, College of Chemistry, Peking University, Beijing 100871, China

${ }^{\mathrm{c}}$ University of Chinese Academy of Sciences, Beijing 100049, China

*Corresponding Author: yuzx@pku.edu.cn, jibaoxia@licp.cas.cn
\end{abstract}

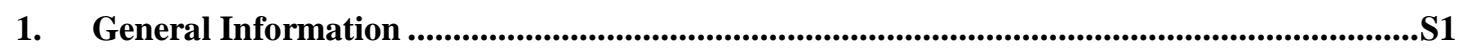

2. Optimization of the Reaction Conditions ...............................................................................

3. General Procedure and Characterization Data ...................................................................S4

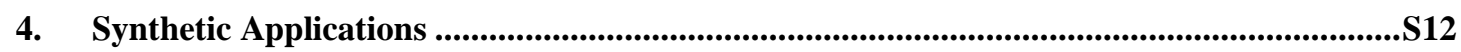

5. Control Experiments and Mechanistic Studies..............................................................S14

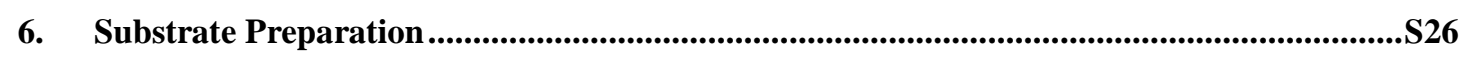

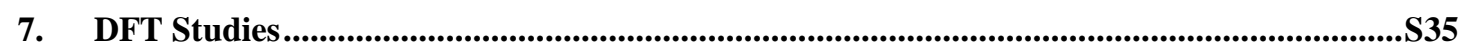

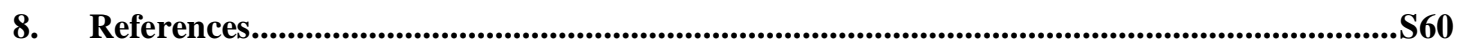

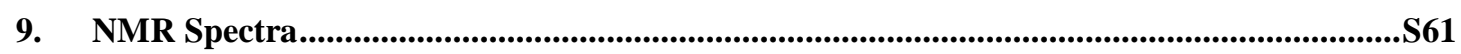




\section{General Information}

All of the Lewis base-catalyzed amino-acylation of allenes were carried out in oven-dried Schlenk tube in dried solvent. Thin layer chromatography (TLC) employed glass $0.25 \mathrm{~mm}$ silica gel plates. Flash chromatography columns were packed with 200-300 mesh silica gel in petroleum (bp. 60-90 ${ }^{\circ} \mathrm{C}$ or $30-60{ }^{\circ} \mathrm{C}$ ). The High Resolution MS analyses were performed on Thermo Fisher Scientific LTQ FT Ultra with DART Positive Mode or Agilent 6530 Accurate-Mass Q-TOF LC/MS with ESI

mode. NMR spectra were recorded on a $400 \mathrm{MHz}$ for ${ }^{1} \mathrm{H}$ NMR and $100 \mathrm{MHz}$ for ${ }^{13} \mathrm{C}$ NMR, using tetramethylsilane as an internal reference and $\mathrm{CDCl}_{3}$ as solvent. Chemical shift values for protons are reported in parts per million (ppm, $\delta$ scale) downfield from tetramethylsilane and are referenced to tetramethylsilane $\left(\begin{array}{ll}\delta & 0\end{array}\right)$. Multiplicity is indicated by one or more of the following: $s$ (singlet); $d$ (doublet); $t$ (triplet); $\mathrm{m}$ (multiplet); br (broad). Carbon nuclear magnetic resonance spectra $\left({ }^{13} \mathrm{C}\right.$ NMR) were recorded at $100 \mathrm{MHz}$. Chemical shifts for carbons are reported in parts per million (ppm, $\delta$ scale) downfield from tetramethylsilane and are referenced to the carbon resonance of $\mathrm{CDCl}_{3}(\delta 77.0)$. Materials were purchased from Tokyo Chemical Industry Co., Aldrich Inc., Alfa Aesar, Adamas, or other commercial suppliers and used as received unless otherwise noted. 


\section{Optimization of the Reaction Conditions}

Table S1. Condition screening for intramolecular amino-acylation of allenes ${ }^{a}$

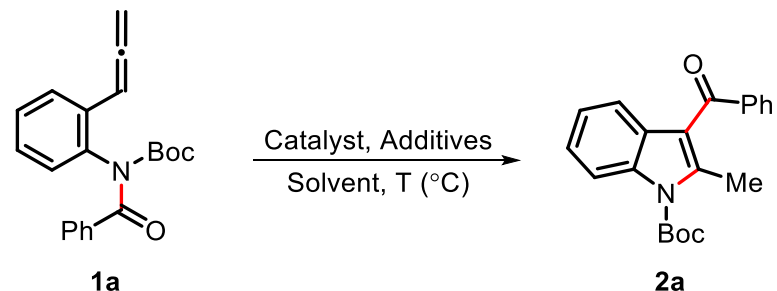

\begin{tabular}{|c|c|c|c|c|}
\hline Entry & Catalyst (x mol \%) & Solvent $(\mathrm{mmol} / \mathrm{mL})$ & $T\left({ }^{\circ} \mathrm{C}\right)$ & Yield $(\%)^{b}$ \\
\hline 1 & (IMes)Ni(allyl)Cl (10) & THF (0.2) & 80 & trace \\
\hline 2 & (IPr)Ni(allyl)Cl (10) & THF (0.2) & 80 & 0 \\
\hline 3 & $\mathrm{IPrCuCl}(10)$ & THF (0.2) & 80 & 0 \\
\hline 4 & $\mathrm{Pd}_{2}(\mathrm{dba})_{3}(10) / \mathrm{I}^{t} \mathrm{Bu}(20)$ & THF (0.2) & 80 & 0 \\
\hline 5 & $\mathrm{Rh}(\operatorname{cod})_{2} \mathrm{SO}_{3} \mathrm{CF}_{3}(10) / \mathrm{I}^{t} \mathrm{Bu}(20)$ & THF (0.2) & 80 & 12 \\
\hline 6 & $\mathrm{Rh}(\operatorname{cod})_{2} \mathrm{SO}_{3} \mathrm{CF}_{3}(10) / \mathrm{IAd}(20)$ & THF (0.2) & 80 & trace \\
\hline 7 & $\mathrm{Rh}(\mathrm{cod})_{2} \mathrm{SO}_{3} \mathrm{CF}_{3}(10) / \mathrm{IMes}(20)$ & THF (0.2) & 80 & 4 \\
\hline 8 & $\mathrm{I}^{t} \mathrm{Bu}(20)$ & THF (0.2) & 80 & 31 \\
\hline 9 & $\mathrm{I}^{t} \mathrm{Bu}(20)$ & 1,4-dioxane $(0.2)$ & 80 & 33 \\
\hline 10 & $\mathrm{I}^{t} \mathrm{Bu}(20)$ & 1,4-dioxane $(0.2)$ & 100 & 35 \\
\hline $11^{c}$ & NHC-Cat. (20) & 1,4-dioxane (0.2) & 100 & 10 \\
\hline 12 & $\mathrm{PPh}_{3}(20)$ & 1,4-dioxane (0.2) & 100 & trace \\
\hline 13 & $\mathrm{PCy}_{3}(20)$ & 1,4-dioxane $(0.2)$ & 100 & 38 \\
\hline 14 & $\mathrm{PBu}_{3}(20)$ & 1,4-dioxane $(0.2)$ & 100 & trace \\
\hline 15 & $\mathrm{P}\left(4-\mathrm{MeOC}_{6} \mathrm{H}_{4}\right)_{3}(20)$ & 1,4-dioxane $(0.2)$ & 100 & 46 \\
\hline 16 & $\mathrm{P}\left(3-\mathrm{MeOC}_{6} \mathrm{H}_{4}\right)_{3}(20)$ & 1,4-dioxane (0.2) & 100 & 7 \\
\hline 17 & $\mathrm{P}\left[2,4,6-(\mathrm{MeO})_{3} \mathrm{C}_{6} \mathrm{H}_{2}\right]_{3}(20)$ & 1,4-dioxane $(0.2)$ & 100 & 3 \\
\hline 18 & $\mathrm{P}\left(\mathrm{NMe}_{2}\right)_{3}(20)$ & 1,4-dioxane (0.2) & 100 & trace \\
\hline 19 & DMAP (20) & 1,4-dioxane (0.2) & 100 & 51 \\
\hline 20 & PPy (20) & 1,4-dioxane (0.2) & 100 & 48 \\
\hline 21 & 4-MeOPy (20) & 1,4-dioxane (0.2) & 100 & 20 \\
\hline 22 & $\mathrm{Et}_{3} \mathrm{~N}(20)$ & 1,4-dioxane $(0.2)$ & 100 & trace \\
\hline 23 & DMAP (20) & $\operatorname{MeCN}(0.2)$ & 100 & 45 \\
\hline
\end{tabular}


Continuing the Table $\mathrm{S} 1$

\begin{tabular}{llccc}
\hline 24 & DMAP (20) & THF (0.2) & 100 & 46 \\
25 & DMAP (20) & toluene (0.2) & 100 & 45 \\
26 & DMAP (20) & MeOH (0.2) & 100 & 0 \\
27 & DMAP (20) & DMF (0.2) & 100 & 0 \\
$28^{d}$ & DMAP (20) & $1,4-\operatorname{dioxane}(0.1)$ & 100 & 37 \\
$29^{d}$ & DMAP (20) & $\operatorname{MeCN}(0.1)$ & 100 & 41 \\
$30^{d}$ & DMAP (20) & THF (0.1) & 100 & 61 \\
$31^{d}$ & DMAP (20) & THF (0.05) & 100 & $66(63)^{e}$ \\
$32^{d}$ & DMAP (10) & THF (0.05) & 100 & 50 \\
$33^{d, f}$ & - & $\operatorname{THF}(0.05)$ & 100 & 0 \\
\hline
\end{tabular}

${ }^{a}$ All reactions were conducted with $1 \mathrm{a}(0.1 \mathrm{mmol})$ for $20 \mathrm{~h}$. ${ }^{b}$ The yield was determined by GC with $n$-dodecane as an internal standard. ${ }^{c}$ With $\mathrm{Na}(\mathrm{OAc})_{2}$ (30 mol \%). ${ }^{d} 48 \mathrm{~h} .{ }^{e}$ Isolated yield in the parenthesis. ${ }^{f}$ Without catalyst.<smiles></smiles>

IMes<smiles></smiles>

IAd<smiles>[2H]P([2H])[2H]</smiles>

$\mathrm{P}\left[2,4,6-(\mathrm{MeO})_{3} \mathrm{C}_{6} \mathrm{H}_{2}\right]_{3}$<smiles></smiles>

$\mathrm{IPr}$<smiles>COc1ccc(P(c2ccc(OC)cc2)c2ccc(OC)cc2)cc1</smiles>

$\mathrm{P}\left(4-\mathrm{MeO}-\mathrm{C}_{6} \mathrm{H}_{4}\right)_{3}$<smiles>CN(C)c1ccncc1</smiles>

DMAP

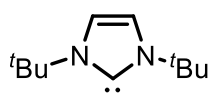

${ }^{t} \mathrm{Bu}$

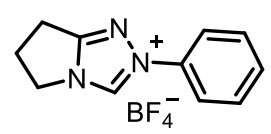

NHC-Cat.<smiles>COc1cccc(P(c2cccc(OC)c2)c2cccc(OC)c2)c1</smiles>

$\mathrm{P}\left(3-\mathrm{MeO}-\mathrm{C}_{6} \mathrm{H}_{4}\right)_{3}$ 


\section{General Procedure and Characterization Data}

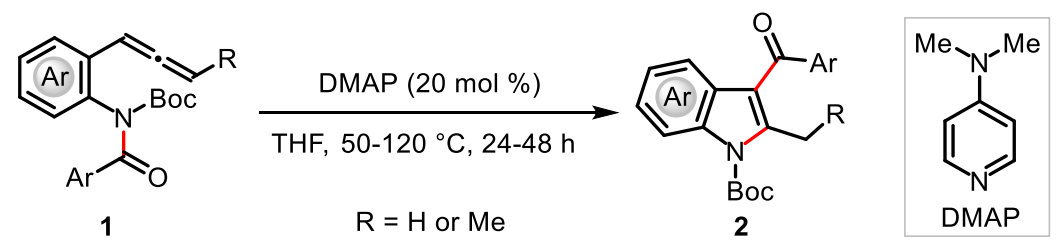

General Procedure: To a $25 \mathrm{~mL}$ oven-dried Schlenk tube was added substrate $\mathbf{1}$ (0.10 mmol), DMAP (0.02 mmol, $2.4 \mathrm{mg})$ and a stir bar. The Schlenk tube was transferred into a $\mathrm{N}_{2}$-filled glovebox and freshly distilled anhydrous THF was added ( $2 \mathrm{~mL}$ ). The tube was then removed out from the glovebox and stirred at $50 \sim 120{ }^{\circ} \mathrm{C}$ for $24 \sim 48$ hours. The resulting mixture was concentrated under vacuum and purified by flash column chromatography on silica gel to give the desired product 2 .

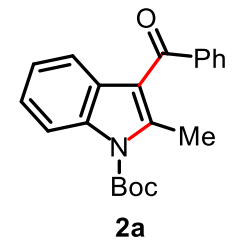

$N$-Boc-3-benzoyl-2-methylindole (2a). Synthesized according to the general procedure with substrate $1 \mathrm{a}(0.10 \mathrm{mmol}, 33.5 \mathrm{mg})$ at $100{ }^{\circ} \mathrm{C}$ for $48 \mathrm{~h}$. Purified by flash column chromatography on silica gel (PE : EA $=30: 1)$ to give $\mathbf{2 a}$ as a colorless oil (21.0 mg, 63\% yield). With 1a $(1.0 \mathrm{mmol}, 335.4 \mathrm{mg})$ as substrate, according to the general procedure (20 mol \% DMAP, $\left.20 \mathrm{~mL} \mathrm{THF}, 100{ }^{\circ} \mathrm{C}, 48 \mathrm{~h}\right)$, 2a was obtained in $52 \%$ yield $(174.2 \mathrm{mg}) .{ }^{1} \mathrm{H}$ NMR $\left(400 \mathrm{MHz}, \mathrm{CDCl}_{3}\right) \delta 8.13(\mathrm{~d}, J=8.4 \mathrm{~Hz}, 1 \mathrm{H}), 7.84$ $(\mathrm{d}, J=7.6 \mathrm{~Hz}, 2 \mathrm{H}), 7.59(\mathrm{t}, J=7.2 \mathrm{~Hz}, 1 \mathrm{H}), 7.46(\mathrm{dd}, J=7.6,7.6 \mathrm{~Hz}, 2 \mathrm{H}), 7.31(\mathrm{~d}, J$ $=7.6 \mathrm{~Hz}, 1 \mathrm{H}), 7.27(\mathrm{~d}, J=7.6 \mathrm{~Hz}, 1 \mathrm{H}), 7.16(\mathrm{dd}, J=7.6,7.6 \mathrm{~Hz}, 1 \mathrm{H}), 2.63(\mathrm{~s}, 3 \mathrm{H})$, $1.72(\mathrm{~s}, 9 \mathrm{H}) .{ }^{13} \mathrm{C} \mathrm{NMR}\left(100 \mathrm{MHz}, \mathrm{CDCl}_{3}\right) \delta 193.4,150.2,142.3,139.5,135.4,132.7$, 129.5, 128.5, 127.9, 124.1, 123.3, 120.4, 119.4, 115.2, 85.0, 28.2, 16.0. HRMS (ESI) Calcd for $\left[\mathrm{C}_{21} \mathrm{H}_{22} \mathrm{NO}_{3}\right]^{+}[\mathrm{M}+\mathrm{H}]^{+} 336.1594$, Found 336.1602.

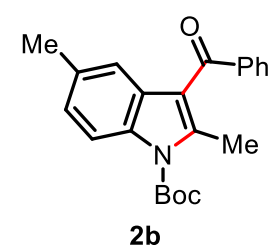

$\boldsymbol{N}$-Boc-3-benzoyl-2,5-dimethylindole (2b). Synthesized according to the general procedure with substrate $\mathbf{1 b}(0.10 \mathrm{mmol}, 34.9 \mathrm{mg})$ at $100{ }^{\circ} \mathrm{C}$ for $48 \mathrm{~h}$. Purified by flash column chromatography on silica gel ( $\mathrm{PE}: \mathrm{EA}=40: 1)$ to give $\mathbf{2 b}$ as a colorless oil (20.5 mg, 59\% yield). ${ }^{1} \mathrm{H}$ NMR (400 MHz, $\left.\mathrm{CDCl}_{3}\right) \delta 7.98(\mathrm{~d}, J=8.4 \mathrm{~Hz}, 1 \mathrm{H}), 7.84$ $(\mathrm{d}, J=7.2 \mathrm{~Hz}, 2 \mathrm{H}), 7.59(\mathrm{t}, J=7.6 \mathrm{~Hz}, 1 \mathrm{H}), 7.46(\mathrm{dd}, J=7.6,7.6 \mathrm{~Hz}, 2 \mathrm{H}), 7.18$ (s, $1 \mathrm{H}), 7.10(\mathrm{~d}, J=8.4 \mathrm{~Hz}, 1 \mathrm{H}), 2.58(\mathrm{~s}, 3 \mathrm{H}), 2.34(\mathrm{~s}, 3 \mathrm{H}), 1.70(\mathrm{~s}, 9 \mathrm{H}) .{ }^{13} \mathrm{C}$ NMR $(100$ $\left.\mathrm{MHz}, \mathrm{CDCl}_{3}\right) \delta 193.6,150.3,142.0,139.7,133.8,132.9,132.7,129.6,128.5,128.2$, 125.5, 120.3, 119.3, 114.9, 84.8, 28.2, 21.3, 16.1. HRMS (ESI) Calcd for 


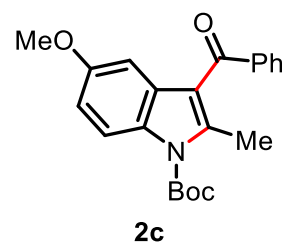

$\mathrm{N}$-Boc-3-benzoyl-5-methoxyl-2-methylindole (2c). Synthesized according to the general procedure with substrate $1 \mathrm{c}(0.10 \mathrm{mmol}, 36.5 \mathrm{mg})$ at $100{ }^{\circ} \mathrm{C}$ for $48 \mathrm{~h}$. Purified by flash column chromatography on silica gel $(\mathrm{PE}: \mathrm{EA}=30: 1)$ to give $\mathbf{2 c}$ as a colorless oil (21.2 mg, 58\% yield). ${ }^{1} \mathrm{H}$ NMR (400 MHz, $\left.\mathrm{CDCl}_{3}\right) \delta 8.00(\mathrm{~d}, J=9.2 \mathrm{~Hz}$, $1 \mathrm{H}), 7.83(\mathrm{~d}, J=7.6 \mathrm{~Hz}, 2 \mathrm{H}), 7.59(\mathrm{t}, J=6.8 \mathrm{~Hz}, 1 \mathrm{H}), 7.47(\mathrm{dd}, J=7.6,7.6 \mathrm{~Hz}, 2 \mathrm{H})$, $6.90-6.87(\mathrm{~m}, 2 \mathrm{H}), 3.70(\mathrm{~s}, 3 \mathrm{H}), 2.58(\mathrm{~s}, 3 \mathrm{H}), 1.70(\mathrm{~s}, 9 \mathrm{H}) .{ }^{13} \mathrm{C}$ NMR $(100 \mathrm{MHz}$, $\left.\mathrm{CDCl}_{3}\right) \delta 193.6,156.2,150.1,142.9,139.6,132.7,130.1,129.5,128.8,128.5,119.2$, 116.0, 113.1, 102.7, 84.9, 55.4, 28.2, 16.3. HRMS (ESI) Calcd for $\left[\mathrm{C}_{22} \mathrm{H}_{24} \mathrm{NO}_{4}\right]^{+}$ $[\mathrm{M}+\mathrm{H}]^{+}$366.1700, Found 366.1709.

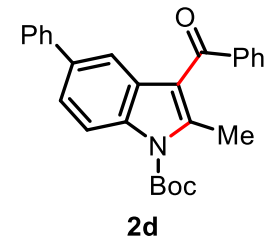

$N$-Boc-3-benzoyl-5-phenyl-2-methylindole (2d). Synthesized according to the general procedure with substrate $1 \mathrm{~d}(0.10 \mathrm{mmol}, 41.1 \mathrm{mg})$ at $100{ }^{\circ} \mathrm{C}$ for $48 \mathrm{~h}$. Purified by flash column chromatography on silica gel (PE : EA $=50: 1)$ to give $\mathbf{2 d}$ as a colorless oil (30.4 mg, 74\% yield). ${ }^{1} \mathrm{H}$ NMR (400 MHz, $\left.\mathrm{CDCl}_{3}\right) \delta 8.17(\mathrm{~d}, J=8.4 \mathrm{~Hz}$, $1 \mathrm{H}), 7.87(\mathrm{~d}, J=7.6 \mathrm{~Hz}, 2 \mathrm{H}), 7.61-7.45(\mathrm{~m}, 7 \mathrm{H}), 7.37$ (dd, $J=7.6,7.6 \mathrm{~Hz}, 2 \mathrm{H}), 7.28$ $(\mathrm{dd}, J=7.2,7.2 \mathrm{~Hz}, 1 \mathrm{H}), 2.64(\mathrm{~s}, 3 \mathrm{H}), 1.73(\mathrm{~s}, 9 \mathrm{H}) .{ }^{13} \mathrm{C} \mathrm{NMR}\left(100 \mathrm{MHz}, \mathrm{CDCl}_{3}\right) \delta$ $193.4,150.2$, 142.8, 141.3, 139.6, 136.6, 135.0, 132.9, 129.6, 128.7, 128.5, 127.3, $126.9,123.7,119.6,118.8,115.5,85.1,28.2,16.2$. HRMS (ESI) Calcd for $\left[\mathrm{C}_{27} \mathrm{H}_{26} \mathrm{NO}_{3}\right]^{+}[\mathrm{M}+\mathrm{H}]^{+}$412.1907, Found 412.1911.

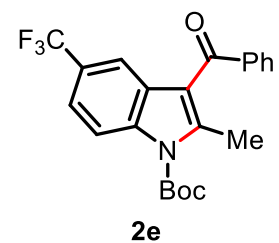

$N$-Boc-3-benzoyl-5-trifluoromethyl-2-methylindole (2e). Synthesized according to the general procedure with substrate 1 e $(0.10 \mathrm{mmol}, 40.3 \mathrm{mg})$ at $70{ }^{\circ} \mathrm{C}$ for $36 \mathrm{~h}$. Purified by flash column chromatography on silica gel (PE : EA $=40: 1$ ) to give $2 \mathbf{e}$ as a colorless oil (34.8 mg, 86\% yield). ${ }^{1} \mathrm{H}$ NMR (400 MHz, $\left.\mathrm{CDCl}_{3}\right) \delta 8.23(\mathrm{~d}, J=8.8$ $\mathrm{Hz}, 1 \mathrm{H}), 7.83(\mathrm{~d}, J=7.6 \mathrm{~Hz}, 2 \mathrm{H}), 7.70(\mathrm{~s}, 1 \mathrm{H}), 7.62(\mathrm{t}, J=7.2 \mathrm{~Hz}, 1 \mathrm{H}), 7.54-7.47$ $(\mathrm{m}, 3 \mathrm{H}), 2.61(\mathrm{~s}, 3 \mathrm{H}), 1.72(\mathrm{~s}, 9 \mathrm{H}) .{ }^{13} \mathrm{C} \mathrm{NMR}\left(100 \mathrm{MHz}, \mathrm{CDCl}_{3}\right) \delta 192.8,149.8$, $143.6,139.2,137.1,133.1,129.5,128.6,127.8,125.8$ (q, $J=32.3 \mathrm{~Hz}), 124.5$ (q, $J=$ 
$270.0 \mathrm{~Hz}), 121.0$ (q, $J=3.4 \mathrm{~Hz}), 119.4,117.8$ (q, $J=3.9 \mathrm{~Hz}), 115.6,85.9,28.2$, 16.2. HRMS (ESI) Calcd for $\left[\mathrm{C}_{22} \mathrm{H}_{21} \mathrm{~F}_{3} \mathrm{NO}_{3}\right]^{+}[\mathrm{M}+\mathrm{H}]^{+}$404.1468, Found 404.1469.

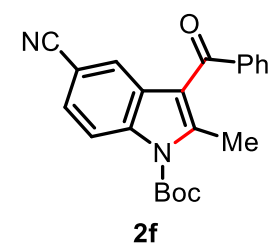

$\mathrm{N}$-Boc-3-benzoyl-5-cyano-2-methylindole (2f). Synthesized according to the general procedure with substrate $\mathbf{1 f}(0.10 \mathrm{mmol}, 36.0 \mathrm{mg})$ at $50{ }^{\circ} \mathrm{C}$ for $24 \mathrm{~h}$. Purified by flash column chromatography on silica gel $(\mathrm{PE}: \mathrm{EA}=20: 1)$ to give $\mathbf{2 f}$ as a colorless oil (28.5 mg, 79\% yield). ${ }^{1} \mathrm{H}$ NMR (400 MHz, $\left.\mathrm{CDCl}_{3}\right) \delta 8.23(\mathrm{~d}, J=8.4 \mathrm{~Hz}, 1 \mathrm{H}), 7.80(\mathrm{~d}$, $J=8.0 \mathrm{~Hz}, 2 \mathrm{H}), 7.70(\mathrm{~s}, 1 \mathrm{H}), 7.64(\mathrm{t}, J=7.6 \mathrm{~Hz}, 1 \mathrm{H}), 7.54-7.48(\mathrm{~m}, 3 \mathrm{H}), 2.63(\mathrm{~s}$, 3H), $1.73(\mathrm{~s}, 9 \mathrm{H}) .{ }^{13} \mathrm{C}$ NMR $\left(100 \mathrm{MHz}, \mathrm{CDCl}_{3}\right) \delta 192.4,149.4,144.2,138.9,137.4$, 133.3, 129.4, 128.7, 128.0, 127.3, 125.1, 119.4, 118.9, 116.1, 106.9, 86.3 28.1, 16.1. HRMS (ESI) Calcd for $\left[\mathrm{C}_{22} \mathrm{H}_{20} \mathrm{~N}_{2} \mathrm{O}_{3} \mathrm{Na}\right]^{+}[\mathrm{M}+\mathrm{Na}]^{+}$383.1366, Found 383.1376.

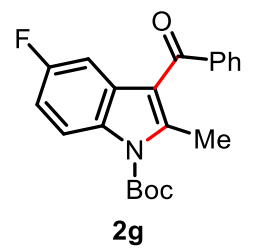

$N$-Boc-3-benzoyl-5-fluoro-2-methylindole (2g). Synthesized according to the general procedure with substrate $1 \mathrm{~g}(0.10 \mathrm{mmol}, 35.4 \mathrm{mg})$ at $60{ }^{\circ} \mathrm{C}$ for $36 \mathrm{~h}$. Purified by flash column chromatography on silica gel (PE : $\mathrm{EA}=40: 1)$ to give $\mathbf{2 g}$ as a colorless oil (32.4 mg, 92\% yield). ${ }^{1} \mathrm{H}$ NMR (400 MHz, $\left.\mathrm{CDCl}_{3}\right) \delta 8.09-8.07(\mathrm{~m}, 1 \mathrm{H})$, $7.81(\mathrm{~d}, J=7.6 \mathrm{~Hz}, 2 \mathrm{H}), 7.59(\mathrm{~d}, J=7.2 \mathrm{~Hz}, 1 \mathrm{H}), 7.47(\mathrm{dd}, J=7.2,6.8 \mathrm{~Hz}, 2 \mathrm{H}), 7.00$ $(\mathrm{dd}, J=10.0,9.2 \mathrm{~Hz}, 2 \mathrm{H}), 2.61(\mathrm{~s}, 3 \mathrm{H}), 1.71(\mathrm{~s}, 9 \mathrm{H}) .{ }^{13} \mathrm{C} \mathrm{NMR}\left(100 \mathrm{MHz}, \mathrm{CDCl}_{3}\right) \delta$ 193.0, 159.4 (d, $J=238.4 \mathrm{~Hz}), 149.9,143.8,139.3,132.9,131.8,129.4,129.9$ (d, $J=$ $10.0 \mathrm{~Hz}), 128.6,119.1(\mathrm{~d}, J=3.9 \mathrm{~Hz}), 116.3(\mathrm{~d}, J=9.0 \mathrm{~Hz}), 111.9(\mathrm{~d}, J=24.8 \mathrm{~Hz})$, $106.0(\mathrm{~d}, J=24.9), 85.3,28.1,16.2$. HRMS (ESI) Calcd for $\left[\mathrm{C}_{21} \mathrm{H}_{20} \mathrm{FNO}_{3} \mathrm{Na}\right]^{+}$ $[\mathrm{M}+\mathrm{Na}]^{+}$376.1319, Found 376.1316.

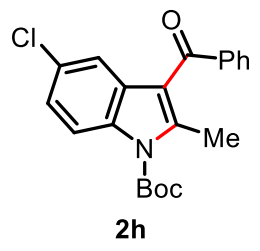

$N$-Boc-3-benzoyl-5-chloro-2-methylindole (2h). Synthesized according to the general procedure with substrate $1 \mathbf{h}(0.10 \mathrm{mmol}, 37.0 \mathrm{mg})$ at $70{ }^{\circ} \mathrm{C}$ for $24 \mathrm{~h}$. Purified by flash column chromatography on silica gel $(\mathrm{PE}: \mathrm{EA}=40: 1)$ to give $\mathbf{2 h}$ as a colorless oil (27.8 mg, 75\% yield). ${ }^{1} \mathrm{H}$ NMR (400 MHz, $\left.\mathrm{CDCl}_{3}\right) \delta 8.05(\mathrm{~d}, J=8.8 \mathrm{~Hz}$, $1 \mathrm{H}), 7.81(\mathrm{~d}, J=7.2 \mathrm{~Hz}, 2 \mathrm{H}), 7.61(\mathrm{t}, J=7.2 \mathrm{~Hz}, 1 \mathrm{H}), 7.48(\mathrm{dd}, J=7.6,7.6 \mathrm{~Hz}, 2 \mathrm{H})$, $7.35(\mathrm{~d}, J=2.0 \mathrm{~Hz}, 1 \mathrm{H}), 7.23(\mathrm{dd}, J=9.2,2.0 \mathrm{~Hz}, 1 \mathrm{H}), 2.59(\mathrm{~s}, 3 \mathrm{H}), 1.71(\mathrm{~s}, 9 \mathrm{H}) .{ }^{13} \mathrm{C}$ 
NMR $\left(100 \mathrm{MHz}, \mathrm{CDCl}_{3}\right) \delta 192.9,149.8,143.3,139.2,133.9,133.0,129.5,129.1$, 128.6, 124.4, 119.9, 118.8, 116.3, 85.5, 28.1, 16.2. HRMS (ESI) Calcd for $\left[\mathrm{C}_{21} \mathrm{H}_{21} \mathrm{ClNO}_{3}\right]^{+}[\mathrm{M}+\mathrm{H}]^{+}$370.1204, Found 370.1210.

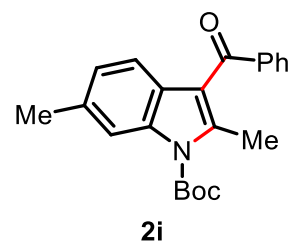

$N$-Boc-3-benzoyl-2,6-methylindole (2i). Synthesized according to the general procedure with substrate $1 \mathbf{i}(0.10 \mathrm{mmol}, 37.0 \mathrm{mg})$ at $120{ }^{\circ} \mathrm{C}$ for $36 \mathrm{~h}$. Purified by flash column chromatography on silica gel $(\mathrm{PE}: \mathrm{EA}=50: 1)$ to give $\mathbf{2 i}$ as a colorless oil (16.3 mg, 47\% yield). ${ }^{1} \mathrm{H}$ NMR $\left(400 \mathrm{MHz}, \mathrm{CDCl}_{3}\right) \delta 7.98(\mathrm{~s}, 1 \mathrm{H}), 7.82(\mathrm{~d}, J=7.2 \mathrm{~Hz}$, $2 \mathrm{H}), 7.57(\mathrm{t}, J=6.8 \mathrm{~Hz}, 1 \mathrm{H}), 7.45(\mathrm{dd}, J=6.8,6.8 \mathrm{~Hz}, 2 \mathrm{H}), 7.15(\mathrm{~d}, J=8.0 \mathrm{~Hz}, 1 \mathrm{H})$, $6.98(\mathrm{~d}, J=7.6 \mathrm{~Hz}, 1 \mathrm{H}), 2.62$ (s, 3H), 2.46 (s, 3H), 1.71 (s, 9H). ${ }^{13} \mathrm{C}$ NMR $(100 \mathrm{MHz}$, $\left.\mathrm{CDCl}_{3}\right) \delta 193.5,150.3,141.6,139.6,135.9,134.1,132.7,129.5,128.4,125.7,124.7$, 120.0, 119.4, 115.4, 84.8, 28.2, 21.9, 16.0. HRMS (ESI) Calcd for $\left[\mathrm{C}_{22} \mathrm{H}_{24} \mathrm{NO}_{3}\right]^{+}$ $[\mathrm{M}+\mathrm{H}]^{+} 350.1751$, Found 350.1748 .

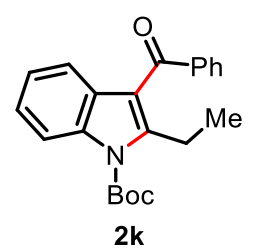

$N$-Boc-3-benzoyl-2-ethynylindole (2k). Synthesized according to the general procedure with substrate $1 \mathbf{k}(0.10 \mathrm{mmol}, 34.9 \mathrm{mg})$, DMAP $(0.03 \mathrm{mmol}, 3.7 \mathrm{mg})$ in THF ( $1 \mathrm{~mL})$ at $100{ }^{\circ} \mathrm{C}$ for $48 \mathrm{~h}$. Purified by flash column chromatography on silica gel $(\mathrm{PE}: \mathrm{EA}=50: 1)$ to give $\mathbf{2 k}$ as a colorless oil $\left(16.9 \mathrm{mg}, 48 \%\right.$ yield). ${ }^{1} \mathrm{H}$ NMR $\left(400 \mathrm{MHz}, \mathrm{CDCl}_{3}\right) \delta 8.13(\mathrm{~d}, J=8.4 \mathrm{~Hz}, 1 \mathrm{H}), 7.83(\mathrm{~d}, J=7.6 \mathrm{~Hz}, 2 \mathrm{H}), 7.58(\mathrm{t}, J=7.2$ $\mathrm{Hz}, 1 \mathrm{H}), 7.45(\mathrm{dd}, J=7.6,7.6 \mathrm{~Hz}, 2 \mathrm{H}), 7.28-7.24(\mathrm{~m}, 1 \mathrm{H}), 7.12-7.10(\mathrm{~m}, 2 \mathrm{H})$, $3.18(\mathrm{q}, J=7.2 \mathrm{~Hz}, 2 \mathrm{H}), 1.73(\mathrm{~s}, 9 \mathrm{H}), 1.29$ (t, $J=7.2 \mathrm{~Hz}, 3 \mathrm{H}) .{ }^{13} \mathrm{C}$ NMR (100 MHz, $\left.\mathrm{CDCl}_{3}\right) \delta 193.5,150.0,147.9,139.6,135.6,132.7,129.5,128.4,127.9,124.1,123.1$, 120.4, 118.9, 115.4, 85.0, 28.1, 21.2, 15.0. HRMS (ESI) Calcd for $\left[\mathrm{C}_{22} \mathrm{H}_{24} \mathrm{NO}_{3}\right]^{+}$ $[\mathrm{M}+\mathrm{H}]^{+} 350.1751$, Found 350.1759 .

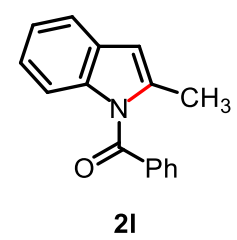

$N$-Benzoyl-2-methylindole (21). Synthesized according to the general procedure with $N$-benzoyl-2-allenylaniline 11 (0.10 mmol, $23.5 \mathrm{mg})$, DMAP $(0.02 \mathrm{mmol}, 2.4 \mathrm{mg})$ in THF ( $2 \mathrm{~mL})$ at $100{ }^{\circ} \mathrm{C}$ for $48 \mathrm{~h}$. Purified by flash column chromatography on silica gel (PE : EA = $50: 1)$ to give $2 \mathbf{l}$ as a white $\operatorname{solid}\left(20.1 \mathrm{mg}, 86 \%\right.$ yield). The ${ }^{1} \mathrm{H}$ NMR 
spectra is the same as the reported data. ${ }^{1}{ }^{1} \mathrm{H}$ NMR $\left(400 \mathrm{MHz}, \mathrm{CDCl}_{3}\right) \delta 7.72(\mathrm{~d}, J=$ $8.0 \mathrm{~Hz}, 2 \mathrm{H}), 7.62(\mathrm{t}, J=7.2 \mathrm{~Hz}, 1 \mathrm{H}), 7.51-7.41(\mathrm{~m}, 3 \mathrm{H}), 7.16-7.12(\mathrm{~m}, 1 \mathrm{H}), 7.04-$ $6.98(\mathrm{~m}, 2 \mathrm{H}), 6.43(\mathrm{~s}, 1 \mathrm{H}), 2.41(\mathrm{~s}, 3 \mathrm{H})$.

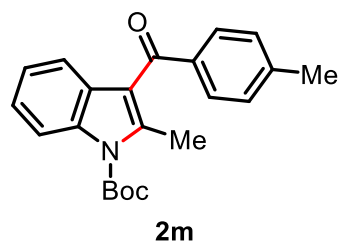

$N$-Boc-3-(4-(methyl)benzoyl)-2-methylindole (2m). Synthesized according to the general procedure with substrate $1 \mathrm{~m}(0.10 \mathrm{mmol}, 34.9 \mathrm{mg})$ at $100{ }^{\circ} \mathrm{C}$ for $48 \mathrm{~h}$. Purified by flash column chromatography on silica gel (PE : EA = 50:1) to give $\mathbf{2 m}$ as a colorless oil $\left(22.5 \mathrm{mg}, 64 \%\right.$ yield). ${ }^{1} \mathrm{H}$ NMR $\left(400 \mathrm{MHz}, \mathrm{CDCl}_{3}\right) \delta 8.12(\mathrm{~d}, J=8.4$ $\mathrm{Hz}, 1 \mathrm{H}), 7.75(\mathrm{~d}, J=8.0 \mathrm{~Hz}, 2 \mathrm{H}), 7.33(\mathrm{~d}, J=8.0 \mathrm{~Hz}, 1 \mathrm{H}), 7.26-7.24(\mathrm{~m}, 3 \mathrm{H}), 7.16$ $(\mathrm{dd}, J=7.6,7.6 \mathrm{~Hz}, 1 \mathrm{H}), 2.63(\mathrm{~s}, 3 \mathrm{H}), 2.43(\mathrm{~s}, 3 \mathrm{H}), 1.71(\mathrm{~s}, 9 \mathrm{H}) .{ }^{13} \mathrm{C} \mathrm{NMR}(100 \mathrm{MHz}$, $\left.\mathrm{CDCl}_{3}\right) \delta 193.1,150.2,143.6,141.7,136.8,135.4,129.8,129.1,128.0,124.0,123.2$, 120.3, 119.6, 115.2, 84.9, 28.2, 21.7, 16.0. HRMS (ESI) Calcd for $\left[\mathrm{C}_{22} \mathrm{H}_{23} \mathrm{NO}_{3} \mathrm{Na}\right]^{+}$ $[\mathrm{M}+\mathrm{Na}]^{+}$372.1570, Found 372.1569.

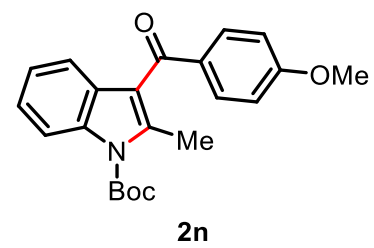

$N$-Boc-3-(4-methoxylbenzoyl)-2-methylindole (2n). Synthesized according to the general procedure with substrate $1 \mathrm{n}(0.10 \mathrm{mmol}, 36.5 \mathrm{mg})$ at $100{ }^{\circ} \mathrm{C}$ for $48 \mathrm{~h}$. Purified by flash column chromatography on silica gel (PE : EA $=20: 1)$ to give $\mathbf{2 n}$ as a colorless oil (26.4 mg, $72 \%$ yield). ${ }^{1} \mathrm{H}$ NMR $\left(400 \mathrm{MHz}, \mathrm{CDCl}_{3}\right) \delta 8.12(\mathrm{~d}, J=8.4 \mathrm{~Hz}$, $1 \mathrm{H}), 7.84(\mathrm{~d}, J=9.2 \mathrm{~Hz}, 2 \mathrm{H}), 7.33(\mathrm{~d}, J=8.0 \mathrm{~Hz}, 1 \mathrm{H}), 7.29-7.24(\mathrm{~m}, 1 \mathrm{H}), 7.17-$ $7.13(\mathrm{~m}, 1 \mathrm{H}), 6.93(\mathrm{~d}, J=8.8 \mathrm{~Hz}, 2 \mathrm{H}), 3.88(\mathrm{~s}, 3 \mathrm{H}), 2.63(\mathrm{~s}, 3 \mathrm{H}), 1.71(\mathrm{~s}, 9 \mathrm{H}) .{ }^{13} \mathrm{C}$ NMR $\left(100 \mathrm{MHz}, \mathrm{CDCl}_{3}\right) \delta 192.0,163.5,150.3,141.1,135.5,132.2,132.0,128.2$, 124.0, 123.2, 120.3, 119.8, 115.2, 113.7, 84.8, 55.5, 28.2, 15.9. HRMS (ESI) Calcd for $\left[\mathrm{C}_{22} \mathrm{H}_{24} \mathrm{NO}_{4}\right]^{+}[\mathrm{M}+\mathrm{H}]^{+}$366.1700, Found 366.1707.

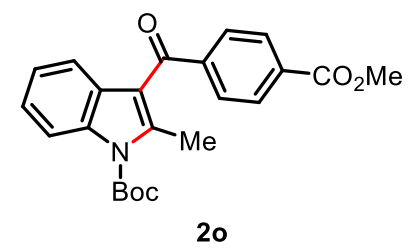

$\mathrm{N}$-Boc-3-(4-(methoxycarbonyl)benzoyl)-2-methylindole (2o). Synthesized according to the general procedure with substrate $10(0.10 \mathrm{mmol}, 39.3 \mathrm{mg})$ at $100{ }^{\circ} \mathrm{C}$ for $48 \mathrm{~h}$. Purified by flash column chromatography on silica gel (PE : EA = $20: 1)$ to give 20 as a colorless oil $\left(27.0 \mathrm{mg}, 68 \%\right.$ yield). ${ }^{1} \mathrm{H} \mathrm{NMR}\left(400 \mathrm{MHz}, \mathrm{CDCl}_{3}\right) \delta 8.14-$ $8.12(\mathrm{~m}, 3 \mathrm{H}), 7.87(\mathrm{~d}, J=6.8 \mathrm{~Hz}, 2 \mathrm{H}), 7.31-7.27(\mathrm{~m}, 2 \mathrm{H}), 7.15(\mathrm{dd}, J=7.2,8.0 \mathrm{~Hz}$, 
1H), $3.96(\mathrm{~s}, 3 \mathrm{H}), 2.64(\mathrm{~s}, 3 \mathrm{H}), 1.72(\mathrm{~s}, 9 \mathrm{H}) .{ }^{13} \mathrm{C} \mathrm{NMR}\left(100 \mathrm{MHz}, \mathrm{CDCl}_{3}\right) \delta$ 192.7, $166.3,150.0,143.3,143.2,135.4,133.4,129.7,129.3,127.6,124.3,123.4,120.3$, 118.9, 115.2, 85.2, 52.4, 28.2, 16.0. HRMS (ESI) Calcd for $\left[\mathrm{C}_{23} \mathrm{H}_{23} \mathrm{NO}_{5} \mathrm{Na}\right]^{+}$ $[\mathrm{M}+\mathrm{Na}]^{+}$416.1468, Found 416.1458 .

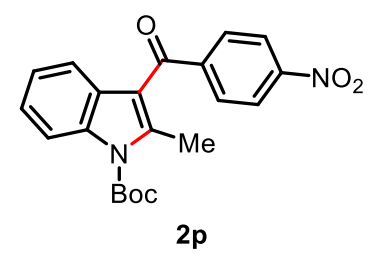

$N$-Boc-3-(4-(nitro)benzoyl)-2-methylindole (2p). Synthesized according to the general procedure with substrate $1 \mathbf{p}(0.10 \mathrm{mmol}, 38.0 \mathrm{mg})$ at $100{ }^{\circ} \mathrm{C}$ for $48 \mathrm{~h}$. Purified by flash column chromatography on silica gel $(\mathrm{PE}: \mathrm{EA}=50: 1)$ to give $\mathbf{2 p}$ as a colorless oil (22.6 mg, 59\% yield). ${ }^{1} \mathrm{H} \mathrm{NMR}\left(400 \mathrm{MHz}, \mathrm{CDCl}_{3}\right) \delta 8.32(\mathrm{~d}, J=8.4 \mathrm{~Hz}$, $2 \mathrm{H}), 8.13(\mathrm{~d}, J=8.4 \mathrm{~Hz}, 1 \mathrm{H}), 7.96(\mathrm{~d}, J=8.8 \mathrm{~Hz}, 2 \mathrm{H}), 7.31(\mathrm{dd}, J=8.0,8.8 \mathrm{~Hz}, 1 \mathrm{H})$, $7.22-7.15(\mathrm{~m}, 2 \mathrm{H}), 2.68(\mathrm{~s}, 3 \mathrm{H}), 1.73(\mathrm{~s}, 9 \mathrm{H}) .{ }^{13} \mathrm{C} \mathrm{NMR}\left(100 \mathrm{MHz}, \mathrm{CDCl}_{3}\right) \delta 191.4$, 150.0, 144.7, 143.9, 135.4, 130.3, 127.3, 124.5, 123.8, 123.6, 120.1, 118.4, 115.4, 85.5, 28.1, 16.0. HRMS (ESI) Calcd for $\left[\mathrm{C}_{21} \mathrm{H}_{20} \mathrm{~N}_{2} \mathrm{O}_{5} \mathrm{Na}\right]^{+}[\mathrm{M}+\mathrm{Na}]^{+} 403.1264$, Found 403.1264.

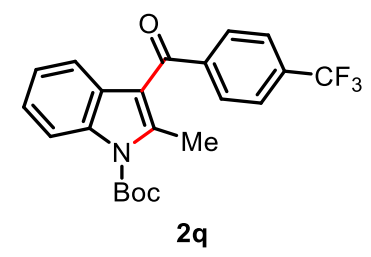

N-Boc-3-(4-(trifluoromethyl)benzoyl)-2-methylindole (2q). Synthesized according to the general procedure with substrate $1 \mathrm{q}(0.10 \mathrm{mmol}, 40.3 \mathrm{mg})$ at $100{ }^{\circ} \mathrm{C}$ for $48 \mathrm{~h}$. Purified by flash column chromatography on silica gel (PE : EA $=50: 1$ ) to give $\mathbf{2 q}$ as a colorless oil (17.7 mg, $44 \%$ yield). ${ }^{1} \mathrm{H}$ NMR $\left(400 \mathrm{MHz}, \mathrm{CDCl}_{3}\right) \delta 8.13(\mathrm{~d}, J=8.4$ $\mathrm{Hz}, 1 \mathrm{H}), 7.92(\mathrm{~d}, J=8.0 \mathrm{~Hz}, 2 \mathrm{H}), 7.73(\mathrm{~d}, J=8.0 \mathrm{~Hz}, 2 \mathrm{H}), 7.31-7.25(\mathrm{~m}, 2 \mathrm{H}), 7.19$ $-7.17(\mathrm{~m}, 1 \mathrm{H}), 2.65(\mathrm{~s}, 3 \mathrm{H}), 1.72(\mathrm{~s}, 9 \mathrm{H}) .{ }^{13} \mathrm{C} \mathrm{NMR}\left(100 \mathrm{MHz}, \mathrm{CDCl}_{3}\right) \delta 192.2$, $150.1,143.3,142.7,135.5,134.0(\mathrm{q}, J=32.6 \mathrm{~Hz}), 129.7,127.6,125.6(\mathrm{q}, J=3.8 \mathrm{~Hz})$, 124.4, 123.9 (q, $J=231.1 \mathrm{~Hz}), 123.6,120.2,118.8,115.3,85.3,28.2$, 16.0. HRMS (ESI) Calcd for $\left[\mathrm{C}_{22} \mathrm{H}_{21} \mathrm{~F}_{3} \mathrm{NO}_{3}\right]^{+}[\mathrm{M}+\mathrm{H}]^{+}$404.1468, Found 404.1476.

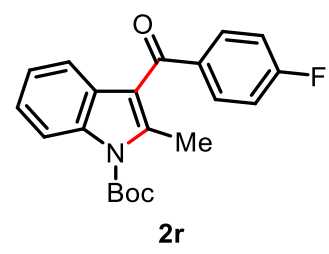

$N$-Boc-3-(4-(fluoro)benzoyl)-2-methylindole (2r). Synthesized according to the general procedure with substrate $1 \mathbf{r}(0.10 \mathrm{mmol}, 35.3 \mathrm{mg})$ at $100{ }^{\circ} \mathrm{C}$ for $48 \mathrm{~h}$. Purified by flash column chromatography on silica gel $(\mathrm{PE}: \mathrm{EA}=40: 1)$ to give $2 \mathbf{r}$ as a colorless oil (24.7 mg, 70\% yield). ${ }^{1} \mathrm{H}$ NMR (400 MHz, $\left.\mathrm{CDCl}_{3}\right) \delta 8.13(\mathrm{~d}, J=8.4 \mathrm{~Hz}$, 
1H), $7.89-7.87(\mathrm{~m}, 2 \mathrm{H}), 7.29-7.26(\mathrm{~m}, 2 \mathrm{H}), 7.18-7.12(\mathrm{~m}, 3 \mathrm{H}), 2.64(\mathrm{~s}, 3 \mathrm{H}), 1.72$ (s, 9H). ${ }^{13} \mathrm{C}$ NMR $\left(100 \mathrm{MHz}, \mathrm{CDCl}_{3}\right) \delta 191.8,165.6(\mathrm{~d}, J=252.7 \mathrm{~Hz}), 150.1,142.2$, $135.8,135.4,132.2(\mathrm{~d}, J=9.1 \mathrm{~Hz}), 127.8,124.2,123.3,120.2,119.2,115.6(\mathrm{~d}, J=$ $21.8 \mathrm{~Hz}$ ), 115.3, 85.1, 28.2, 15.9. HRMS (ESI) Calcd for $\left[\mathrm{C}_{21} \mathrm{H}_{21} \mathrm{FNO}_{3}\right]^{+}[\mathrm{M}+\mathrm{H}]^{+}$ 354.1500, Found 354.1508.

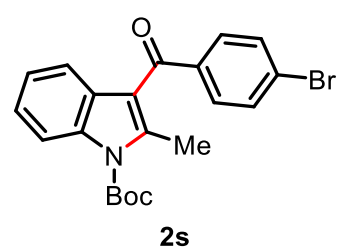

$\boldsymbol{N}$-Boc-3-(4-(bromo)benzoyl)-2-methylindole (2s). Synthesized according to the general procedure with substrate $1 \mathrm{~s}(0.10 \mathrm{mmol}, 41.4 \mathrm{mg})$, DMAP $(0.02 \mathrm{mmol}, 2.4$ $\mathrm{mg})$ in THF ( $2 \mathrm{~mL})$ at $100{ }^{\circ} \mathrm{C}$ for $48 \mathrm{~h}$. Purified by flash column chromatography on silica gel $(\mathrm{PE}: \mathrm{EA}=40: 1)$ to give $2 \mathrm{~s}$ as a colorless oil $(19.2 \mathrm{mg}, 46 \%$ yield $) .{ }^{1} \mathrm{H}$ NMR $\left(400 \mathrm{MHz}, \mathrm{CDCl}_{3}\right) \delta 8.12(\mathrm{~d}, J=8.8 \mathrm{~Hz}, 1 \mathrm{H}), 7.70(\mathrm{~d}, J=8.0 \mathrm{~Hz}, 2 \mathrm{H}), 7.60(\mathrm{~d}$, $J=8.4 \mathrm{~Hz}, 2 \mathrm{H}), 7.30-7.26(\mathrm{~m}, 2 \mathrm{H}), 7.17(\mathrm{dd}, J=7.6,7.2 \mathrm{~Hz}, 1 \mathrm{H}), 2.64(\mathrm{~s}, 3 \mathrm{H}), 1.72$ (s, 9H). ${ }^{13} \mathrm{C}$ NMR $\left(100 \mathrm{MHz}, \mathrm{CDCl}_{3}\right) \delta 192.2,150.1,142.6,138.3,135.4,131.8$, 131.1, 127.8, 127.7, 124.3, 123.4, 120.2, 118.9, 115.3, 85.2, 28.2, 16.0. HRMS (ESI) Calcd for $\left[\mathrm{C}_{21} \mathrm{H}_{20} \mathrm{BrNO}_{3} \mathrm{Na}\right]^{+}[\mathrm{M}+\mathrm{Na}]^{+} 436.0519$, Found 436.0517 .

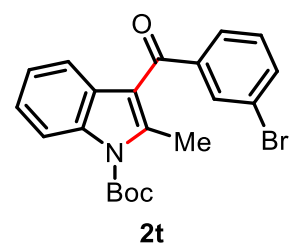

$N$-Boc-3-(3-(bromo)benzoyl)-2-methylindole (2t). Synthesized according to the general procedure with substrate $1 \mathrm{t}(0.10 \mathrm{mmol}, 41.4 \mathrm{mg})$ at $100{ }^{\circ} \mathrm{C}$ for $48 \mathrm{~h}$. Purified by flash column chromatography on silica gel $(\mathrm{PE}: \mathrm{EA}=40: 1)$ to give $\mathbf{2 t}$ as a colorless oil (23.5 mg, 57\% yield). ${ }^{1} \mathrm{H}$ NMR (400 MHz, $\left.\mathrm{CDCl}_{3}\right) \delta 8.12(\mathrm{~d}, J=8.4 \mathrm{~Hz}$, $1 \mathrm{H}), 7.97(\mathrm{~s}, 1 \mathrm{H}), 7.72(\mathrm{dd}, J=7.6,7.2 \mathrm{~Hz}, 2 \mathrm{H}), 7.35-7.26(\mathrm{~m}, 3 \mathrm{H}), 7.18(\mathrm{dd}, J=$ 7.6, 7.6 Hz, 1H), $2.64(\mathrm{~s}, 3 \mathrm{H}), 1.72(\mathrm{~s}, 9 \mathrm{H}) .{ }^{13} \mathrm{C} \mathrm{NMR}\left(100 \mathrm{MHz}, \mathrm{CDCl}_{3}\right) \delta 191.8$, $150.1,142.9,141.4,135.5,135.4,132.3,130.1,128.1,127.6,124.3,123.5,122.7$, 120.2, 118.8, 115.3, 85.2, 28.2, 16.0. HRMS (ESI) Calcd for $\left[\mathrm{C}_{21} \mathrm{H}_{20} \mathrm{BrNO}_{3} \mathrm{Na}\right]^{+}$ $[\mathrm{M}+\mathrm{Na}]^{+}$436.0519, Found 436.0510.

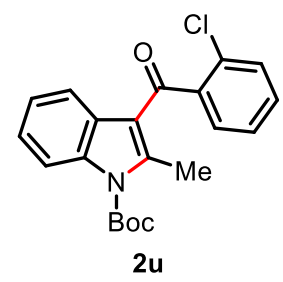

$\boldsymbol{N}$-Boc-3-(2-(chloro)benzoyl)-2-methylindole (2u). Synthesized according to the general procedure with substrate $1 \mathbf{u}(0.10 \mathrm{mmol}, 37.0 \mathrm{mg})$ at $100{ }^{\circ} \mathrm{C}$ for $48 \mathrm{~h}$. Purified 
by flash column chromatography on silica gel (PE : $\mathrm{EA}=50: 1)$ to give $\mathbf{2 u}$ as a colorless oil (12.7 mg, 34\% yield). ${ }^{1} \mathrm{H}$ NMR (400 MHz, $\left.\mathrm{CDCl}_{3}\right) \delta 8.07$ (d, $J=8.4 \mathrm{~Hz}$, $1 \mathrm{H}), 7.75-7.43(\mathrm{~m}, 3 \mathrm{H}), 7.38(\mathrm{~d}, J=6.4 \mathrm{~Hz}, 1 \mathrm{H}), 7.33-7.26(\mathrm{~m}, 2 \mathrm{H}), 7.16(\mathrm{dd}, J=$ 7.6, $7.2 \mathrm{~Hz}, 1 \mathrm{H}), 2.67(\mathrm{~s}, 3 \mathrm{H}), 1.71(\mathrm{~s}, 9 \mathrm{H}) .{ }^{13} \mathrm{C} \mathrm{NMR}\left(100 \mathrm{MHz}, \mathrm{CDCl}_{3}\right) \delta 191.5$, 149.9, 145.6, 141.1, 135.6, 131.3, 131.2, 130.4, 129.1, 127.3, 127.1, 124.3, 123.8, 120.3, 119.0, 114.9, 85.4, 28.1, 15.3. HRMS (ESI) Calcd for $\left[\mathrm{C}_{21} \mathrm{H}_{20} \mathrm{CINO}_{3} \mathrm{Na}\right]^{+}$ $[\mathrm{M}+\mathrm{Na}]^{+}$392.1024, Found 392.1017.

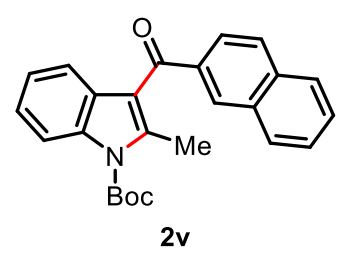

$N$-Boc-3-(2-naphthoyl)-2-methylindole (2v). Synthesized according to the general procedure with substrate $1 \mathbf{v}(0.10 \mathrm{mmol}, 38.5 \mathrm{mg})$ at $100{ }^{\circ} \mathrm{C}$ for $48 \mathrm{~h}$. Purified by flash column chromatography on silica gel ( $\mathrm{PE}: \mathrm{EA}=50: 1)$ to give $\mathbf{2 v}$ as a colorless oil (14.0 mg, 36\% yield). ${ }^{1} \mathrm{H}$ NMR (400 MHz, $\left.\mathrm{CDCl}_{3}\right) \delta 8.32(\mathrm{~s}, 1 \mathrm{H}), 8.15(\mathrm{~d}, J=8.4$ $\mathrm{Hz}, 1 \mathrm{H}), 7.98-7.87(\mathrm{~m}, 4 \mathrm{H}), 7.61(\mathrm{dd}, J=7.6,6.4 \mathrm{~Hz}, 1 \mathrm{H}), 7.53(\mathrm{dd}, J=7.6,7.2 \mathrm{~Hz}$, $1 \mathrm{H}), 7.35-7.26(\mathrm{~m}, 2 \mathrm{H}), 7.14(\mathrm{dd}, J=8.0,7.6 \mathrm{~Hz}, 1 \mathrm{H}), 2.66(\mathrm{~s}, 3 \mathrm{H}), 1.73(\mathrm{~s}, 9 \mathrm{H})$. ${ }^{13} \mathrm{C} \mathrm{NMR}\left(100 \mathrm{MHz}, \mathrm{CDCl}_{3}\right) \delta{ }^{13} \mathrm{C} \mathrm{NMR}\left(100 \mathrm{MHz}, \mathrm{CDCl}_{3}\right) \delta 193.4,150.2,142.2$, $136.8,135.5,132.5,131.5,129.5,128.4,128.3,128.1,127.8,126.7,125.2,124.2$, $123.4,122.2,120.4,119.6,115.2,85.0,28.2$, 16.0. HRMS (ESI) Calcd for $\left[\mathrm{C}_{25} \mathrm{H}_{24} \mathrm{NO}_{3}\right]^{+}[\mathrm{M}+\mathrm{H}]^{+}$386.1751, Found 386.1757.

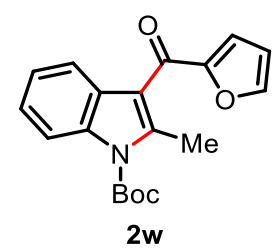

$\mathrm{N}$-Boc-3-(furan-2-carbonyl)-2-methylindole (2w). Synthesized according to the general procedure with substrate $1 \mathbf{w}(0.10 \mathrm{mmol}, 32.5 \mathrm{mg})$ at $100{ }^{\circ} \mathrm{C}$ for $48 \mathrm{~h}$. Purified by flash column chromatography on silica gel (PE : EA $=20: 1)$ to give $\mathbf{2 w}$ as a colorless oil (26.8 mg, 82\% yield). ${ }^{1} \mathrm{H}$ NMR (400 MHz, $\left.\mathrm{CDCl}_{3}\right) \delta 8.12(\mathrm{~d}, J=8.4$ $\mathrm{Hz}, 1 \mathrm{H}), 7.69-7.62(\mathrm{~m}, 1 \mathrm{H}), 7.52$ (d, J=7.6 Hz, 1H), $7.30-7.26$ (m, 1H), 7.21 (dd, $J=7.6,7.6 \mathrm{~Hz}, 1 \mathrm{H}), 7.16(\mathrm{~d}, J=3.6 \mathrm{~Hz}, 1 \mathrm{H}), 6.58(\mathrm{dd}, J=3.6,1.2 \mathrm{~Hz}, 1 \mathrm{H}), 2.69$ (s, $3 \mathrm{H}), 1.71(\mathrm{~s}, 9 \mathrm{H}) .{ }^{13} \mathrm{C} \mathrm{NMR}\left(100 \mathrm{MHz}, \mathrm{CDCl}_{3}\right) \delta 179.7,153.5,150.1,146.7,141.6$, 135.5, 127.5, 124.2, 123.3, 119.9, 119.6, 119.0, 115.3, 112.3, 85.0, 28.2, 15.8. HRMS (ESI) Calcd for $\left[\mathrm{C}_{19} \mathrm{H}_{19} \mathrm{NO}_{4} \mathrm{Na}\right]^{+}[\mathrm{M}+\mathrm{Na}]^{+} 348.1206$, Found 348.1201.

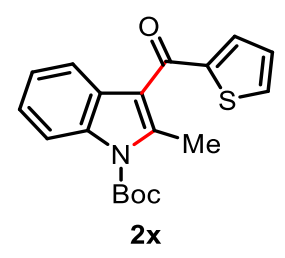


$N$-Boc-3-(thiophene-2-carbonyl)-2-methylindole (2x). Synthesized according to the general procedure with substrate $1 \mathbf{x}(0.10 \mathrm{mmol}, 34.1 \mathrm{mg})$ at $100{ }^{\circ} \mathrm{C}$ for $48 \mathrm{~h}$. Purified by flash column chromatography on silica gel (PE : $\mathrm{EA}=30: 1)$ to give $\mathbf{2} \mathbf{x}$ as a colorless oil (27.4mg, 80\% yield). ${ }^{1} \mathrm{H}$ NMR $\left(400 \mathrm{MHz}, \mathrm{CDCl}_{3}\right) \delta 8.13(\mathrm{~d}, J=8.4 \mathrm{~Hz}$, $1 \mathrm{H}), 7.71(\mathrm{~d}, J=3.6 \mathrm{~Hz}, 1 \mathrm{H}), 7.58(\mathrm{~s}, 1 \mathrm{H}), 7.51(\mathrm{~d}, J=7.2 \mathrm{~Hz}, 1 \mathrm{H}), 7.28(\mathrm{dd}, J=9.6$, $6.8 \mathrm{~Hz}, 1 \mathrm{H}), 7.20(\mathrm{dd}, J=7.6,7.6 \mathrm{~Hz}, 1 \mathrm{H}), 7.11-7.11(\mathrm{~m}, 1 \mathrm{H}), 2.69$ (s, 3H), 1.71 (s, 9H). ${ }^{13} \mathrm{C} \mathrm{NMR}\left(100 \mathrm{MHz}, \mathrm{CDCl}_{3}\right) \delta 184.9,150.2,145.6,140.8,135.4,134.6,134.2$, 128.0, 127.7, 124.2, 123.2, 120.0, 119.7, 115.3, 84.9, 28.2, 16.0. HRMS (ESI) Calcd for $\left[\mathrm{C}_{19} \mathrm{H}_{20} \mathrm{NO}_{3} \mathrm{~S}\right]^{+}[\mathrm{M}+\mathrm{H}]^{+}$342.1158, Found 342.1157 .

\section{Synthetic Applications}

\section{Preparation of $3 \mathrm{H}$-indole 3}<smiles>Cc1c(C(=O)c2ccccc2)c2ccccc2n1C(C)(C)C</smiles>

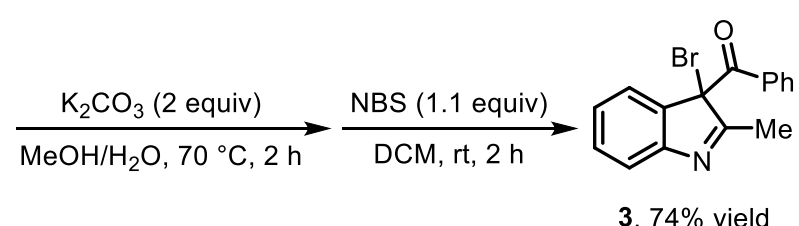

$3,74 \%$ yield

To a $25 \mathrm{~mL}$ Schlenk tube was added $2 \mathrm{a}(0.1 \mathrm{mmol}, 33.5 \mathrm{mg}), \mathrm{K}_{2} \mathrm{CO}_{3}(0.2 \mathrm{mmol}, 27.6$ $\mathrm{mg}$ ) and $\mathrm{MeOH} / \mathrm{H}_{2} \mathrm{O}(3 / 1,1 \mathrm{~mL})$. The mixture was stirred at $70{ }^{\circ} \mathrm{C}$ for $5 \mathrm{~h}$. The solution was cooled to room temperature and filtered. The filtrate was dried over $\mathrm{Na}_{2} \mathrm{SO}_{4}$ and concentrated under vacuum to give crude 3-benzoyl-2-methylindole as a solid without further purification. Then, crude 3-benzoyl-2-methylindole was dissolved in DCM $(1 \mathrm{~mL})$. To the above solution was added $N$-bromosuccinimide $(0.11 \mathrm{mmol}, 19.5 \mathrm{mg})$ and the resulting mixture was stirred at room temperature for 2 h. The mixture was evaporated to get the crude product, which was purified by flash silica gel chromatography with petroleum ether/ethyl acetate (5:1) to give $3 \mathrm{H}$-indole 3 as a white solid ( $23.3 \mathrm{mg}, 74 \%$ yield). Compound $\mathbf{3}$ is very difficult to be dissolved in various deuterated solvents. ${ }^{1} \mathrm{H}$ NMR $\left(400 \mathrm{MHz}, \mathrm{CDCl}_{3}\right) \delta 7.74(\mathrm{~d}, J=6.8 \mathrm{~Hz}, 3 \mathrm{H})$, $7.57(\mathrm{dd}, J=7.6,7.6 \mathrm{~Hz}, 1 \mathrm{H}), 7.48-7.45(\mathrm{~m}, 3 \mathrm{H}), 7.27-7.26(\mathrm{~m}, 1 \mathrm{H}), 7.26-7.25$ $(\mathrm{m}, 1 \mathrm{H}), 2.54(\mathrm{~s}, 3 \mathrm{H})$. HRMS (ESI) Calcd for $\left[\mathrm{C}_{16} \mathrm{H}_{12} \mathrm{BrNONa}\right]^{+}[\mathrm{M}+\mathrm{Na}]^{+} 335.9994$, Found 335.9986.

\section{Preparation of benzilic bromide 4 .}
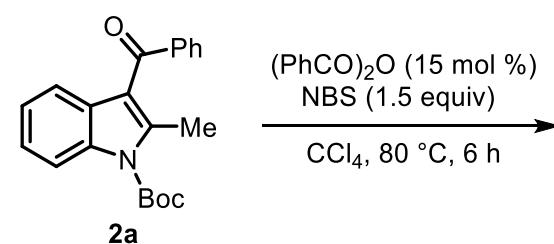

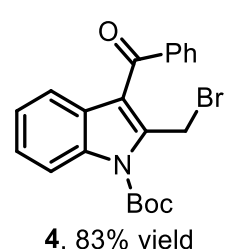

$4,83 \%$ yield

To a solution of $\mathbf{2 a}(0.1 \mathrm{mmol}, 33.5 \mathrm{mg})$ in $\mathrm{CCl}_{4}(1 \mathrm{~mL})$ was added $\mathrm{N}$-bromosuccinimide $(0.1 \mathrm{mmol}, 17.8 \mathrm{mg})$ and benzoyl peroxide $(0.01 \mathrm{mmol}, 2.3 \mathrm{mg})$. The mixture was heated at $80{ }^{\circ} \mathrm{C}$ for $3 \mathrm{~h}$. Then, an additional portion of $\mathrm{N}$-bromosuccinimide $(0.05 \mathrm{mmol}, 8.9 \mathrm{mg})$ and benzoyl peroxide $(0.005 \mathrm{mmol}, 1.2 \mathrm{mg})$ was added. The mixture was stirred at $80{ }^{\circ} \mathrm{C}$ for another $3 \mathrm{~h}$. After cooling to room 
temperature and filtered. The filtrate was evaporated to get the crude product, which was purified by flash silica gel chromatography with petroleum ether/ethyl acetate (50:1) to give benzilic bromide 4 as a colorless oil (43.2 $\mathrm{mg}, 83 \%$ yield). ${ }^{1} \mathrm{H}$ NMR $\left(400 \mathrm{MHz}, \mathrm{CDCl}_{3}\right) \delta 8.20(\mathrm{~d}, J=8.4 \mathrm{~Hz}, 1 \mathrm{H}), 7.84(\mathrm{~d}, J=8.0 \mathrm{~Hz}, 2 \mathrm{H}), 7.61(\mathrm{dd}, J=$ 7.6, $6.8 \mathrm{~Hz}, 1 \mathrm{H}), 7.47(\mathrm{dd}, J=7.6,7.2 \mathrm{~Hz}, 2 \mathrm{H}), 7.27-7.33(\mathrm{~m}, 1 \mathrm{H}), 7.14(\mathrm{~d}, J=3.6$ $\mathrm{Hz}, 2 \mathrm{H}), 5.12$ (s, 2H), 1.76 (s, 9H). $\left.{ }^{13} \mathrm{C} \mathrm{NMR} \mathrm{(100} \mathrm{MHz,} \mathrm{CDCl} 3\right) \delta$ 192.7, 149.3, $138.9,138.8,136.2,133.3,129.7,128.6,127.0,125.8,123.6,121.5,121.2,115.6$, 86.0, 28.0, 23.8. HRMS (ESI) Calcd for $\left[\mathrm{C}_{21} \mathrm{H}_{20} \mathrm{BrNO}_{3} \mathrm{Na}\right]^{+}[\mathrm{M}+\mathrm{Na}]^{+} 436.0519$, Found 436.0523.

\section{Preparation of 3-alkenyl indole 5}

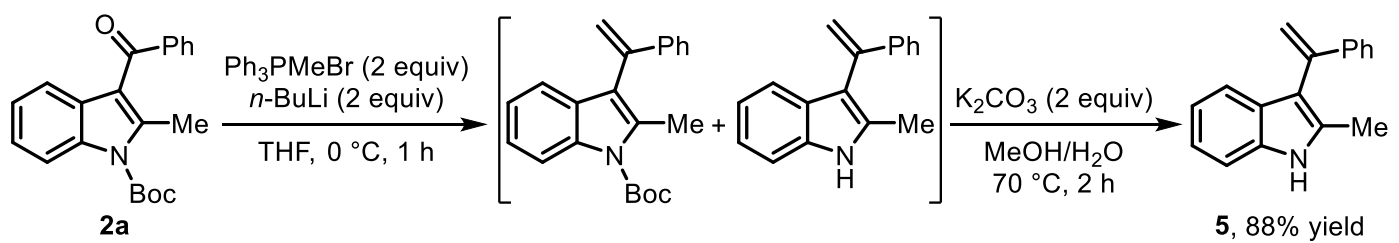

The $n$-BuLi (0.28 mmol, 1.3 M in THF, $215 \mathrm{uL}$ ) was added dropwise to a suspension of methyltriphenylphosphoniumbromide $(0.28 \mathrm{mmol}, 100 \mathrm{mg})$ in dry THF $(4.4 \mathrm{~mL})$ at $0{ }^{\circ} \mathrm{C}$ and the reaction mixture was stirred for 20 min under nitrogen. To the ylide was added $2 \mathrm{a}(0.14 \mathrm{mmol}, 46.9 \mathrm{mg})$ and the reaction mixture was stirred under nitrogen at $0{ }^{\circ} \mathrm{C}$ for $1 \mathrm{~h}$. Aqueous $\mathrm{HCl}$ solution $(1 \mathrm{~mol} / \mathrm{L})$ was added and the mixture was extracted with ethyl acetate. The combined organic phases were evaporated to get the crude mixture of olefin products without further purification. Then, to a solution of crude mixture of olefin products was added $\mathrm{K}_{2} \mathrm{CO}_{3}(0.28 \mathrm{mmol}, 38.7 \mathrm{mg})$ in $\mathrm{MeOH} / \mathrm{H}_{2} \mathrm{O}(3: 1,2 \mathrm{~mL})$. The reaction mixture was refluxed at $70{ }^{\circ} \mathrm{C}$ for $2 \mathrm{~h}$. The solution was cooled to room temperature and filtered. The filtrate was dried over $\mathrm{Na}_{2} \mathrm{SO}_{4}$ and evaporated to get the crude product, which was purified by flash silica gel chromatography with petroleum ether/ethyl acetate (10:1) to give 3-alkenyl 5.as a colorless oil (28.8 mg, $88 \%$ yield). The ${ }^{1} \mathrm{H}$ NMR spectra is the same as the reported data. ${ }^{2}{ }^{1} \mathrm{H}$ NMR $\left(400 \mathrm{MHz}, \mathrm{CDCl}_{3}\right) \delta 7.91(\mathrm{~s}, 1 \mathrm{H}), 7.39(\mathrm{~d}, J=5.6 \mathrm{~Hz}, 2 \mathrm{H}), 7.30-$ $7.27(\mathrm{~m}, 3 \mathrm{H}), 7.22-7.20(\mathrm{~m}, 1 \mathrm{H}), 7.10(\mathrm{dd}, J=7.6,7.2 \mathrm{~Hz}, 1 \mathrm{H}), 6.98(\mathrm{dd}, J=7.6$, $7.2 \mathrm{~Hz}, 1 \mathrm{H}), 5.72(\mathrm{~s}, 1 \mathrm{H}), 5.32(\mathrm{~s}, 1 \mathrm{H}), 2.24(\mathrm{~s}, 3 \mathrm{H})$.

\section{Preparation of indole 6}
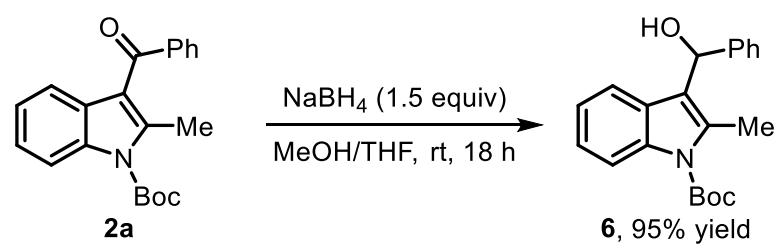

6, $95 \%$ yield

To a dry THF/MeOH solution $(1 \mathrm{~mL} / 1 \mathrm{~mL})$ of $2 \mathbf{a}(0.1 \mathrm{mmol}, 33.5 \mathrm{mg})$ was added $\mathrm{NaBH}_{4}(0.15 \mathrm{mmol}, 5.7 \mathrm{mg})$ at $0{ }^{\circ} \mathrm{C}$. The reaction mixture was allowed warm to room temperature and was stirred for $18 \mathrm{~h}$. the reaction was quenched with water and diluted with ethyl acetate. The organic layer was washed with water and brine, and then dried over dry $\mathrm{Na}_{2} \mathrm{SO}_{4}$. After concentration under reduced pressure, the residue 
was purified by flash silica gel chromatography with petroleum ether/ethyl acetate (10:1) to give 6 as a colorless oil $\left(33.6 \mathrm{mg}, 95 \%\right.$ yield). ${ }^{1} \mathrm{H} \mathrm{NMR}\left(400 \mathrm{MHz}, \mathrm{CDCl}_{3}\right) \delta$ $8.08(\mathrm{~d}, J=8.4 \mathrm{~Hz}, 1 \mathrm{H}), 7.44-7.41(\mathrm{~m}, 3 \mathrm{H}), 7.29(\mathrm{dd}, J=7.6,7.4 \mathrm{~Hz}, 2 \mathrm{H}), 7.23-$ $7.17(\mathrm{~m}, 2 \mathrm{H}), 7.07(\mathrm{dd}, J=7.6,7.2 \mathrm{~Hz}, 1 \mathrm{H}), 6.16(\mathrm{~s}, 1 \mathrm{H}), 2.62(\mathrm{~s}, 3 \mathrm{H}), 1.67$ (s, 9H). ${ }^{13} \mathrm{C}$ NMR $\left(100 \mathrm{MHz}, \mathrm{CDCl}_{3}\right) \delta 150.6,142.8,136.0,134.7,128.2,127.7,127.0,125.8$, 123.4, 122.5, 120.0, 119.7, 115.3, 83.9, 68.7, 28.2, 14.2. HRMS (ESI) Calcd for $\left[\mathrm{C}_{21} \mathrm{H}_{23} \mathrm{NO}_{3} \mathrm{Na}\right]^{+}[\mathrm{M}+\mathrm{Na}]^{+}$360.1570, Found 360.1561.

\section{Preparation of pravadoline}

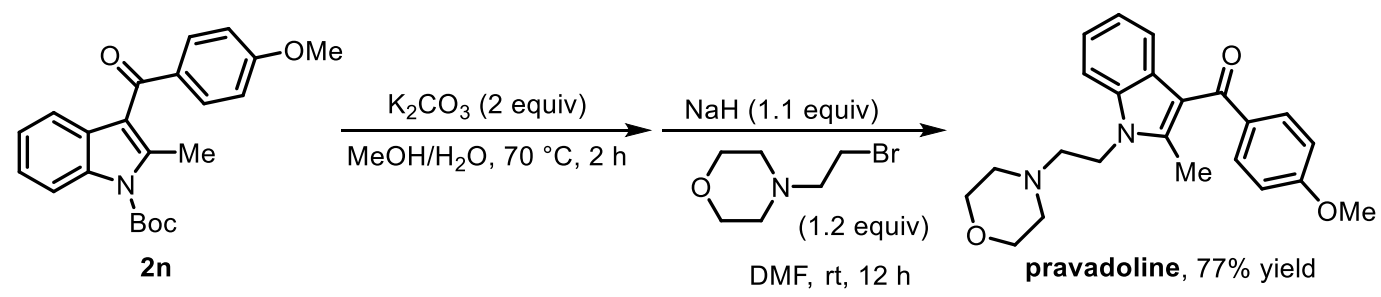

To a $25 \mathrm{~mL}$ Schlenk tube was added $2 \mathrm{n}$ ( $0.18 \mathrm{mmol}, 67.1 \mathrm{mg}), \mathrm{K}_{2} \mathrm{CO}_{3}(0.54 \mathrm{mmol}$, $74.6 \mathrm{mg}$ ) and $\mathrm{MeOH} / \mathrm{H}_{2} \mathrm{O}(3 / 1,2 \mathrm{~mL})$. The mixture was stirred at $70{ }^{\circ} \mathrm{C}$ for $5 \mathrm{~h}$. The solution was cooled to room temperature and filtered. The filtrate was dried over $\mathrm{Na}_{2} \mathrm{SO}_{4}$ and concentrated under vacuum to give crude $\mathrm{N}-\mathrm{H} 3$-aroylindole without further purification. To an anhydrous DMF (2 mL) solution of the crude $N-\mathrm{H}$ 3-aroylindole was added $\mathrm{NaH}(0.2 \mathrm{mmol}, 60 \%$ in mineral oil, $8.0 \mathrm{mg})$ slowly at $0{ }^{\circ} \mathrm{C}$. The reaction mixture was stirred continuously at $0{ }^{\circ} \mathrm{C}$ for $30 \mathrm{~min}$ before 4-(2-bromoethyl)morpholine $(0.22 \mathrm{mmol}, 42.7 \mathrm{mg})$ was added. The mixture was stirred at room temperature for $12 \mathrm{~h}$. The reaction mixture was quenched by a dropwise addition of water. The mixture was extracted with ethyl acetate and the combined organic phases were dried over $\mathrm{Na}_{2} \mathrm{SO}_{4}$ and evaporated to get the crude product, which was purified by flash silica gel chromatography with petroleum ether/ethyl acetate (10:1) to give pravadoline as a white solid $(52.1 \mathrm{mg}, 77 \%$ yield). The ${ }^{1} \mathrm{H}$ NMR spectra is the same as the reported data. ${ }^{3}{ }^{1} \mathrm{H} \mathrm{NMR}\left(400 \mathrm{MHz}, \mathrm{CDCl}_{3}\right) \delta$ $7.77(\mathrm{~d}, J=8.8 \mathrm{~Hz}, 2 \mathrm{H}), 7.37(\mathrm{~d}, J=8.0 \mathrm{~Hz}, 1 \mathrm{H}), 7.32(\mathrm{~d}, J=8.0 \mathrm{~Hz}, 1 \mathrm{H}), 7.19$ (dd, $J$ $=7.6,7.6 \mathrm{~Hz}, 1 \mathrm{H}), 7.07(\mathrm{dd}, J=7.6,7.2 \mathrm{~Hz}, 1 \mathrm{H}), 6.92(\mathrm{~d}, J=8.4 \mathrm{~Hz}, 2 \mathrm{H}), 4.25(\mathrm{t}, J=$ $6.8 \mathrm{~Hz}, 2 \mathrm{H}), 3.86(\mathrm{~s}, 3 \mathrm{H}), 3.72-3.71(\mathrm{brs}, 4 \mathrm{H}), 2.70(\mathrm{t}, J=6.8 \mathrm{~Hz}, 2 \mathrm{H}), 2.60(\mathrm{~s}, 3 \mathrm{H})$, $2.53-2.51$ (brs, $4 \mathrm{H})$.

\section{Control Experiments and Mechanistic Studies}

\section{Radical-trapping experiment}
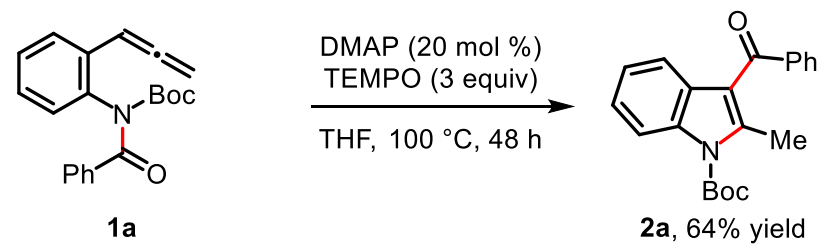

To a $25 \mathrm{~mL}$ oven-dried Schlenk tube was added $1 \mathbf{a}(0.10 \mathrm{mmol}, 33.5 \mathrm{mg})$, TEMPO (0.3 mmol, $47.9 \mathrm{mg})$, DMAP (0.02 mmol, $2.4 \mathrm{mg})$ and a stir bar. The Schlenk tube 
was transferred into a $\mathrm{N}_{2}$-filled glovebox and added freshly distilled THF ( $2 \mathrm{~mL}$ ). The tube was then removed out from the glovebox and stirred at $100{ }^{\circ} \mathrm{C}$ for $48 \mathrm{~h}$. The resulting mixture was concentrated under vacuum and purified by flash column chromatography on silica gel ( $\mathrm{PE}: \mathrm{EA}=30: 1)$ to give the desired product $\mathbf{2 a}$ as a colorless oil (20.9 mg, 64\% yield).

\section{Crossover reaction}

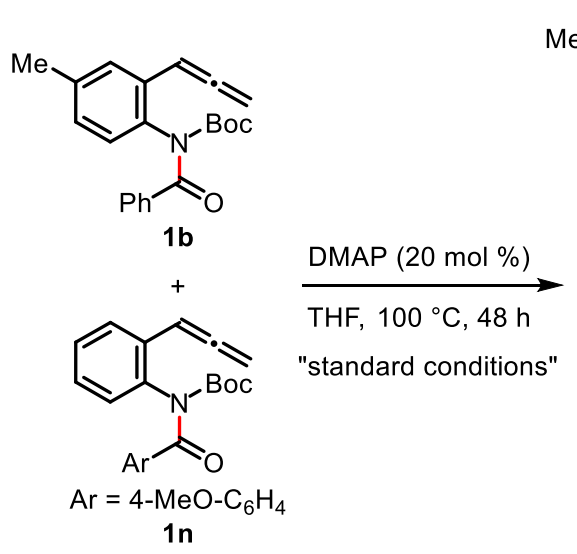

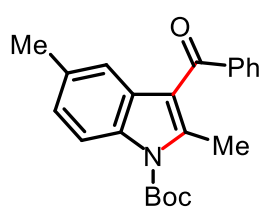

$2 b, 54 \%$ yield

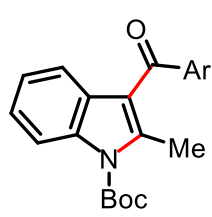

$2 n, 62 \%$ yield

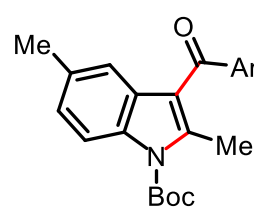

$0 \%$ yield

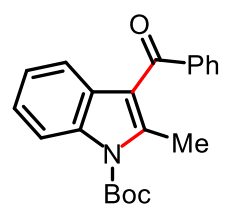

$0 \%$ yield

To a $25 \mathrm{~mL}$ oven-dried Schlenk tube was added $\mathbf{1 b}(0.1 \mathrm{mmol}, 34.9 \mathrm{mg})$ and $\mathbf{1 n}(0.1$ mmol, $36.5 \mathrm{mg}$ ), DMAP (0.02 mmol, $2.4 \mathrm{mg}$ ) and a stir bar. The Schlenk tube was transferred into a $\mathrm{N}_{2}$-filled glovebox and added freshly distilled THF ( $2 \mathrm{~mL}$ ). The tube was then removed out from the glovebox and stirred at $100{ }^{\circ} \mathrm{C}$ for 48 hours. The resulting mixture was concentrated under vacuum and purified by flash column chromatography on silica gel to give $\mathbf{2 b}$ (18.9 mg, $54 \%$ yield) and $2 \mathbf{n}(22.8 \mathrm{mg}, 62 \%$ yield) and no corresponding crossover product was observed in this reaction.

\section{Deuterium labeling experiment}

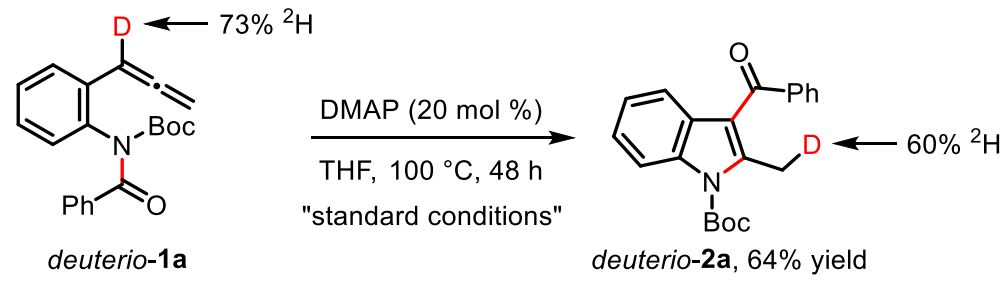

To a $25 \mathrm{~mL}$ oven-dried Schlenk tube was added deuterio-1a $(0.10 \mathrm{mmol}, 33.6 \mathrm{mg})$, DMAP (0.02 mmol, $2.4 \mathrm{mg}$ ) and a stir bar. The Schlenk tube was transferred into a $\mathrm{N}_{2}$-filled glovebox and added freshly distilled THF $(2 \mathrm{~mL})$. The tube was then removed out from the glovebox and stirred at $100{ }^{\circ} \mathrm{C}$ for 48 hours. The resulting mixture was concentrated under vacuum and purified by flash column chromatography on silica gel $(\mathrm{PE}: \mathrm{EA}=30: 1)$ to give the product deuterio-2a as a colorless oil (21.6 mg, 64\% yield). The ${ }^{1} \mathrm{H}$ NMR spectra of deuterio-1a was compared with ${ }^{1} \mathrm{H}$ NMR spectra of 1a, indicating that there was $70 \%{ }^{2} \mathrm{H}$ at $\alpha$-postion of allene in deuterio-1a. After the reaction, the ${ }^{1} \mathrm{H}$ NMR spectra of deuterio-2a was compared with ${ }^{1} \mathrm{H}$ NMR spectra of $\mathbf{2 a}$, a single deuterium atom $\left(70 \%{ }^{2} \mathrm{H}\right)$ was incorporated at the 2-methyl group of the 3-aroylindole product deuterio-2a. 
${ }^{1} \mathrm{H}$ NMR spectrum of $\mathbf{1 a}$ and deuterio-1a
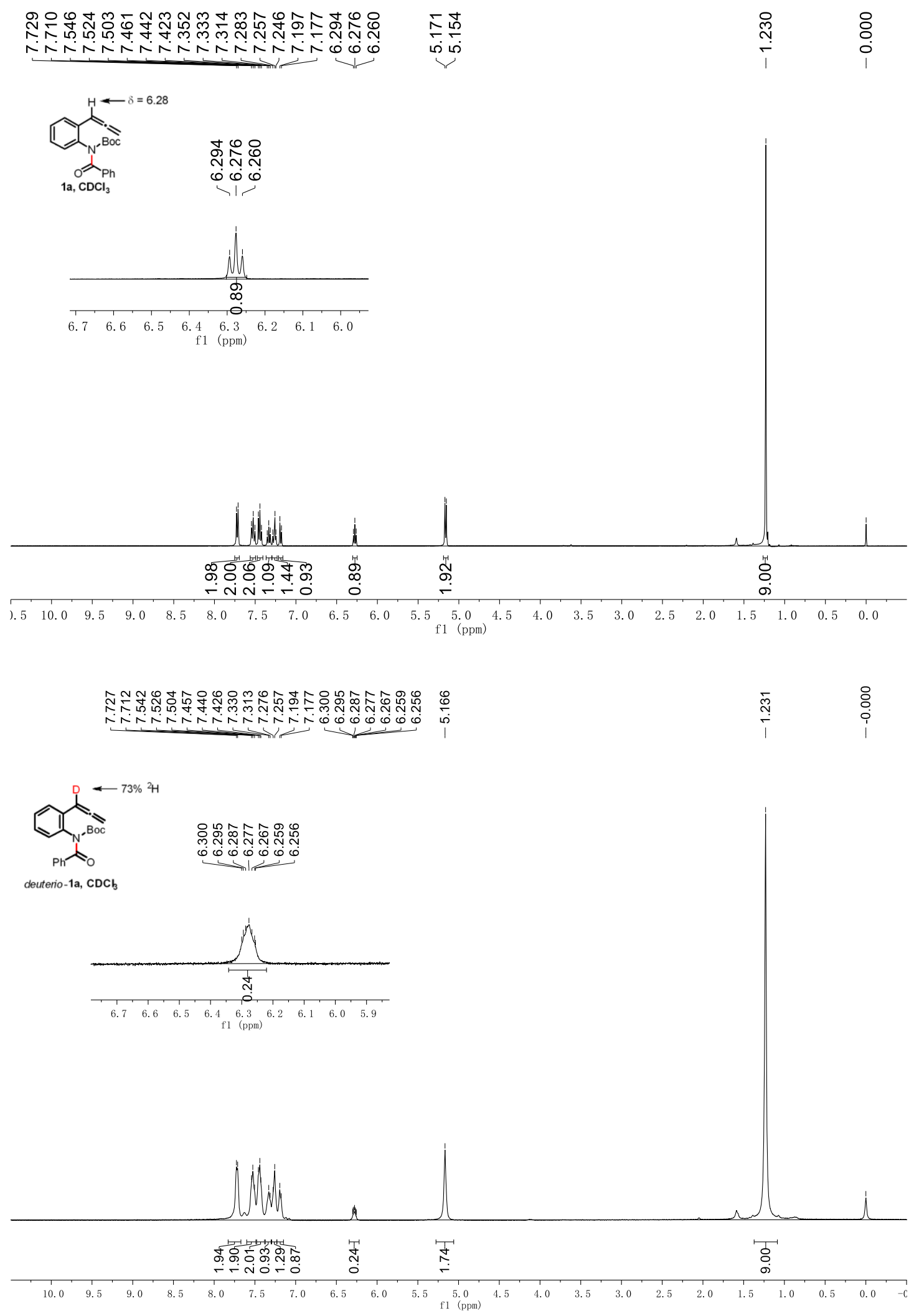
${ }^{1} \mathrm{H}$ NMR spectrum of $\mathbf{2 a}$ and deuterio-2a

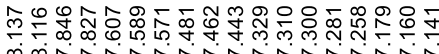

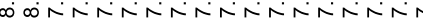

$\stackrel{\substack{0 \\ i}}{i} \underset{i}{i} \quad \frac{8}{i}$

(1)
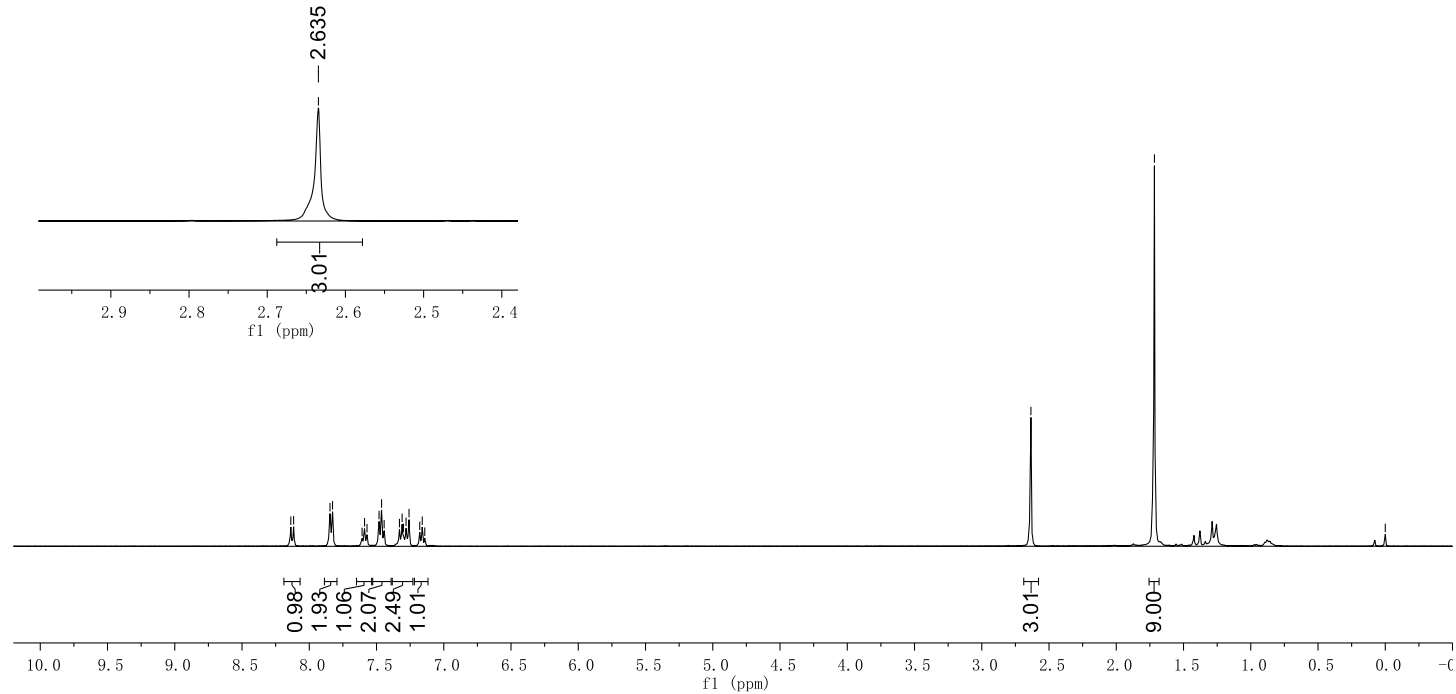

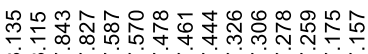

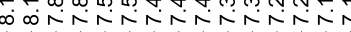

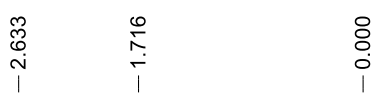

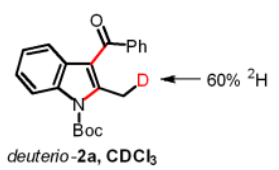

deuterio-2 $\mathrm{a}, \mathrm{CDCl}_{3}$
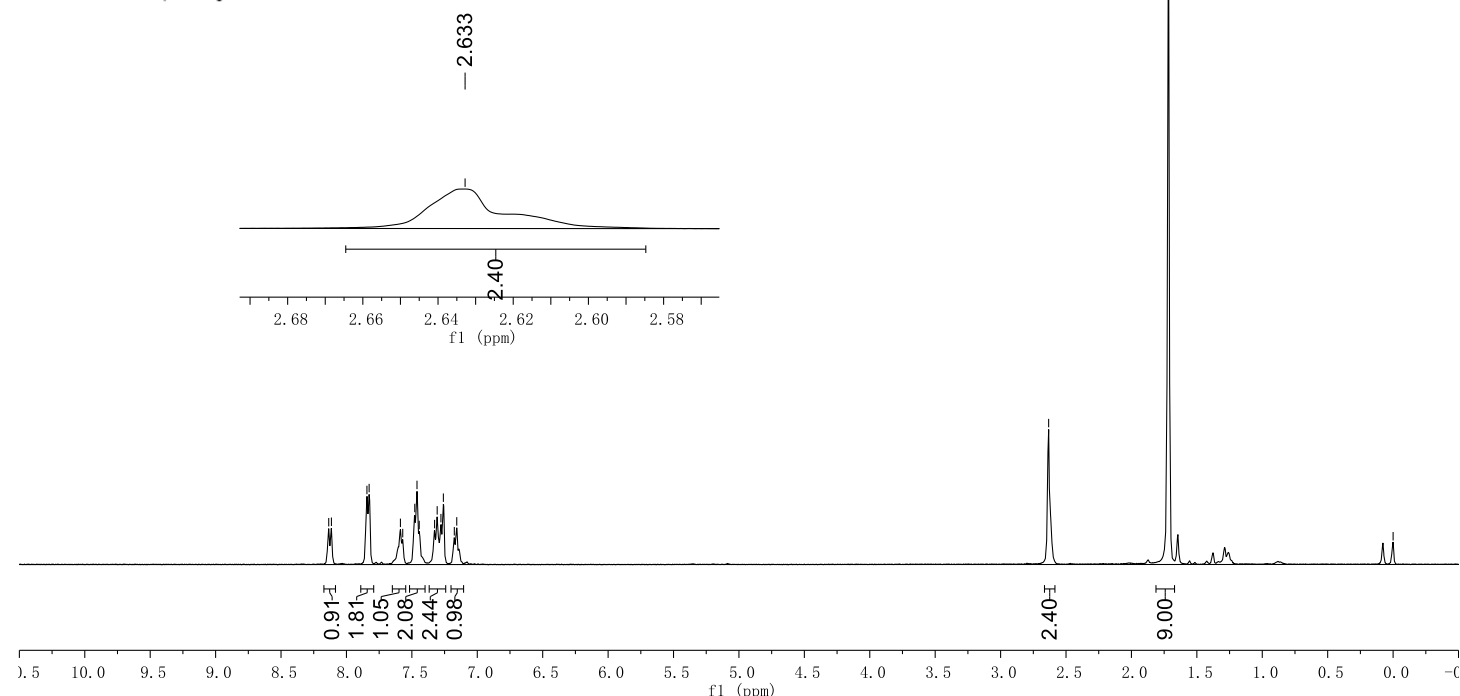
Deuterium scrambling experiment with substrate deuterio-1a and 1n

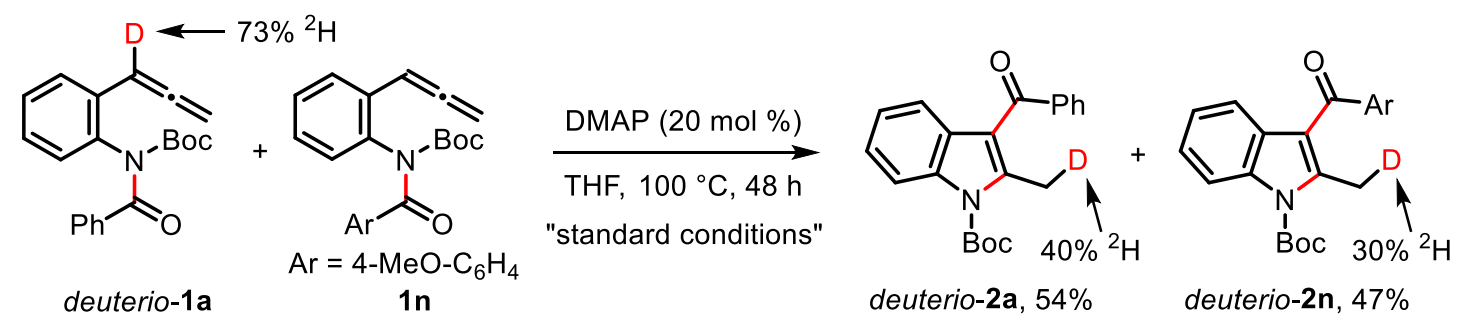

To a $25 \mathrm{~mL}$ oven-dried Schlenk tube was added deuterio-1a $(0.10 \mathrm{mmol}, 33.6 \mathrm{mg})$, 1n $(0.10 \mathrm{mmol}, 36.5 \mathrm{mg})$, DMAP $(0.02 \mathrm{mmol}, 2.4 \mathrm{mg})$ and a stir bar. The Schlenk tube was transferred into a $\mathrm{N}_{2}$-filled glovebox and added freshly distilled THF (2 mL). The tube was then removed out from the glovebox and stirred at $100{ }^{\circ} \mathrm{C}$ for 48 hours. The resulting mixture was concentrated under vacuum and purified by flash column chromatography on silica gel (PE : EA $=30: 1)$ to give the product deuterio-2a (18.3 mg, 54\% yield) and deuterio-2n (17.1 mg, 47\% yield) as a colorless oil. The ${ }^{1} \mathrm{H}$ NMR spectra of deuterio-2a was compared with ${ }^{1} \mathrm{H}$ NMR spectra of $\mathbf{2 a}$, a single deuterium atom $\left(40 \%{ }^{2} \mathrm{H}\right)$ was incorporated at the 2-methyl group of the 3-aroylindole product deuterio-2a. The ${ }^{1} \mathrm{H}$ NMR spectra of deuterio-2n was compared with ${ }^{1} \mathrm{H}$ NMR spectra of $2 \mathbf{n}$, a single deuterium atom $\left(30 \%{ }^{2} \mathrm{H}\right)$ was incorporated at the 2-methyl group of the 3-aroylindole product deuterio-2n.

${ }^{1} \mathrm{H}$ NMR spectrum of deuterio-2a
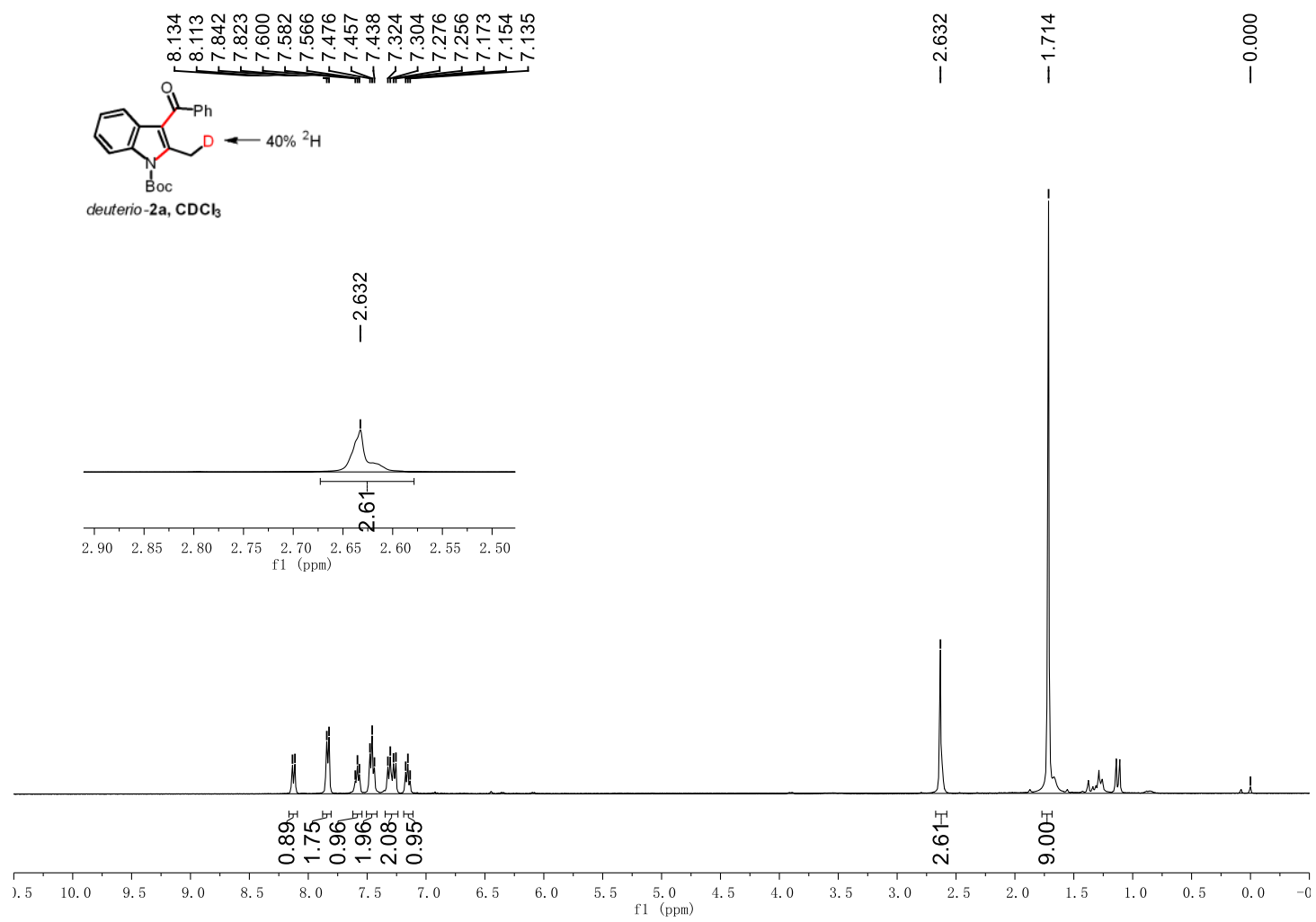
${ }^{1} \mathrm{H}$ NMR spectrum of $\mathbf{2 n}$ and deuterio-2n

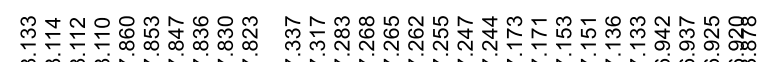

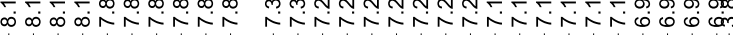

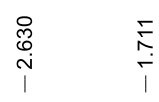

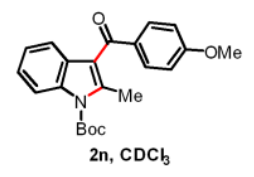

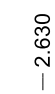
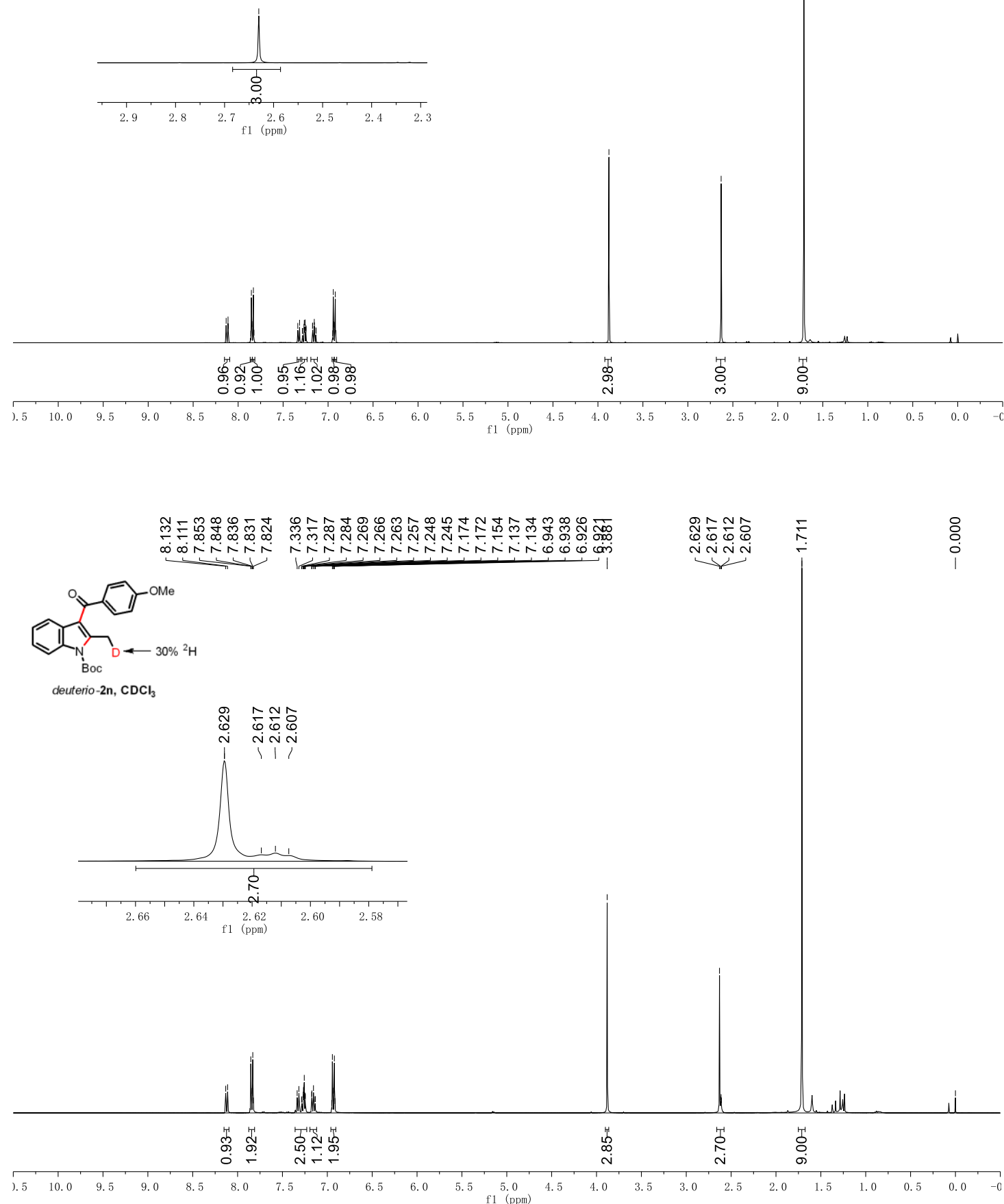
Deuterium scrambling experiment with substrate 1n and product deuterio-2a<smiles>C=Cc1ccccc1N(C(=O)OCC)C(=[Te])C(=O)OCC</smiles>

1n
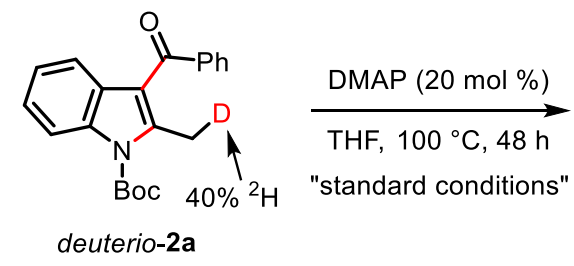

"standard conditions"

deuterio-2

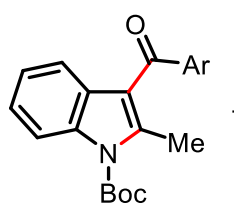

2n, $50 \%$

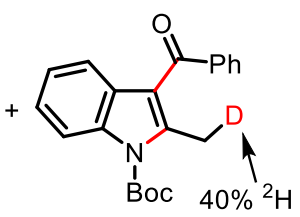

deuterio-2a, $95 \%$ recovery

To a $25 \mathrm{~mL}$ oven-dried Schlenk tube was added deuterio-2a $(0.05 \mathrm{mmol}, 16.8 \mathrm{mg})$, 1n $(0.05 \mathrm{mmol}, 18.2 \mathrm{mg})$, DMAP $(0.01 \mathrm{mmol}, 1.2 \mathrm{mg})$ and a stir bar. The Schlenk tube was transferred into a $\mathrm{N}_{2}$-filled glovebox and added freshly distilled THF (1 mL). The tube was then removed out from the glovebox and stirred at $100{ }^{\circ} \mathrm{C}$ for 48 hours. The resulting mixture was concentrated under vacuum and purified by flash column chromatography on silica gel ( $\mathrm{PE}: \mathrm{EA}=30: 1)$ to give the product deuterio-2a (16.0 $\mathrm{mg}, 95 \%$ yield recovery) and $\mathbf{2 n}\left(9.1 \mathrm{mg}, 50 \%\right.$ yield) as a colorless oil. The ${ }^{1} \mathrm{H}$ NMR spectra of deuterio-2a was compared with ${ }^{1} \mathrm{H}$ NMR spectra of $\mathbf{2 a}$, a single deuterium atom $\left(40 \%{ }^{2} \mathrm{H}\right)$ was incorporated at the 2-methyl group of the 3-aroylindole product deuterio-2a.

\section{Deuterium scrambling experiment with 1a in the presence of $\mathrm{D}_{2} \mathrm{O}$}<smiles>C=C=Cc1ccccc1N(C(=O)OCc1ccccc1)C(=O)c1ccccc1</smiles>

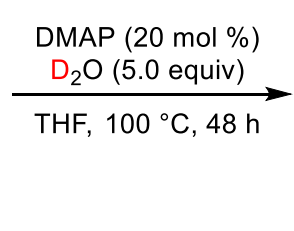

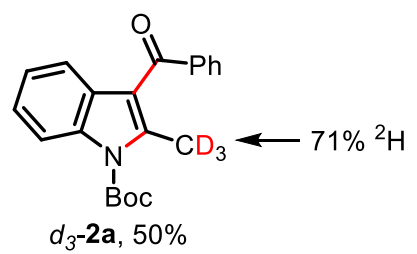

To a $25 \mathrm{~mL}$ oven-dried Schlenk tube was added $1 \mathrm{a}(0.10 \mathrm{mmol}, 33.5 \mathrm{mg})$, DMAP (0.02 mmol, $2.4 \mathrm{mg}$ ) and a stir bar. The Schlenk tube was transferred into a $\mathrm{N}_{2}$-filled glovebox and added freshly distilled THF $(2 \mathrm{~mL})$. The tube was then removed out from the glovebox and was added $\mathrm{D}_{2} \mathrm{O}(0.5 \mathrm{mmol}, 10 \mathrm{uL})$ under $\mathrm{N}_{2}$ atomosphere. The reaction mixture stirred at $100{ }^{\circ} \mathrm{C}$ for $48 \mathrm{~h}$. The resulting mixture was concentrated under vacuum and purified by flash column chromatography on silica gel (PE : EA = $30: 1)$ to give the product $d_{3}-\mathbf{2 a}$ as a colorless oil (16.8 $\mathrm{mg}, 50 \%$ yield). The ${ }^{1} \mathrm{H}$ NMR spectra of $d_{3}$-2a was compared with ${ }^{1} \mathrm{H}$ NMR spectra of $\mathbf{2 a}$, three deuterium atom $(71 \%$ ${ }^{2} \mathrm{H}$ ) was incorporated at the 2-methyl group of the 3-aroylindole product $d_{3}$-2a. 
${ }^{1} \mathrm{H}$ NMR spectrum of $d_{3}-\mathbf{2 a}$

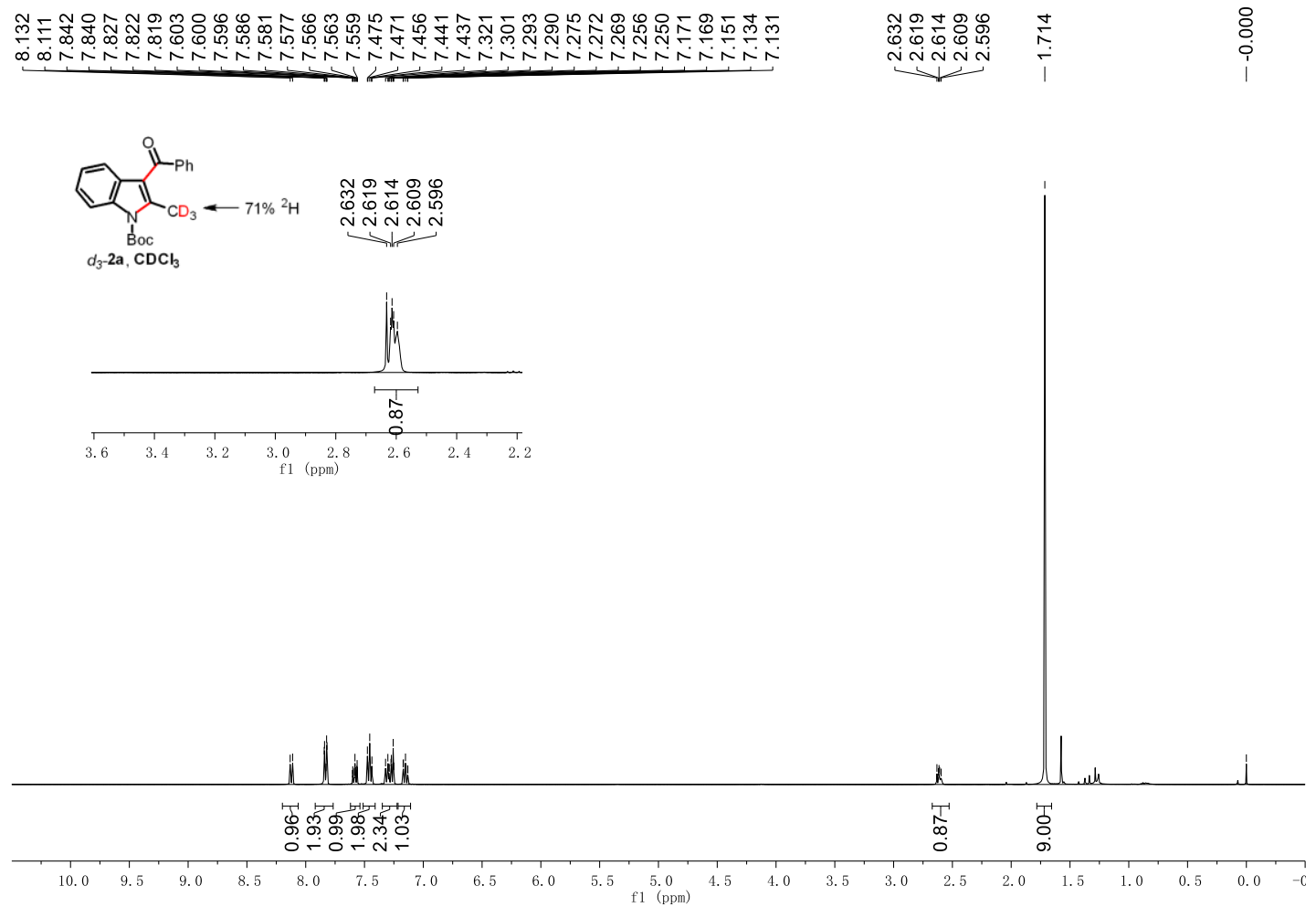

\section{In situ ${ }^{31} \mathrm{P}$ and ${ }^{1} \mathrm{H}$ NMR monitoring experiments}

We attempt to detect or isolate DMAP-incorporated reaction intemediate was unsuccessful. We used in situ ${ }^{31} \mathrm{P}$ NMR to detect the reaction intermediate with $\mathrm{P}\left(4-\mathrm{MeO}-\mathrm{C}_{6} \mathrm{H}_{4}\right)_{3}$, which showed moderate catalytic reactivity in condition screening (Table S1, entry 15). The reaction was run with $\mathbf{1 f}$ as substrate in the presence of 1 equivalent of acetic acid in $\mathrm{CD}_{3} \mathrm{CN}$<smiles></smiles>

To an oven-dried NMR tube was added $1 \mathbf{f}(0.05 \mathrm{mmol}, 18.0 \mathrm{mg}), \mathrm{P}\left(4-\mathrm{MeO}-\mathrm{C}_{6} \mathrm{H}_{4}\right)_{3}$ (0.05 mmol, $17.6 \mathrm{mg})$, HOAc $(0.05 \mathrm{mmol}, 2.9 \mathrm{uL})$ and $\mathrm{CD}_{3} \mathrm{CN}(0.5 \mathrm{~mL})$ in a $\mathrm{N}_{2}$-filled glovebox. The NMR tube was sealed and removed out from the glovebox. The mixture was monitored by ${ }^{31} \mathrm{P}$ and ${ }^{1} \mathrm{H}$ NMR. The mixture was analysed by High Resolution MS after 12 hours. HRMS (ESI) Calcd for A $\left[\mathrm{C}_{43} \mathrm{H}_{42} \mathrm{~N}_{2} \mathrm{O}_{6} \mathrm{P}\right]^{+}$[M-(OAc) $]$ 713.2775, Found 713.2782. 
${ }^{31} \mathrm{P}$ NMR monitoring experiment

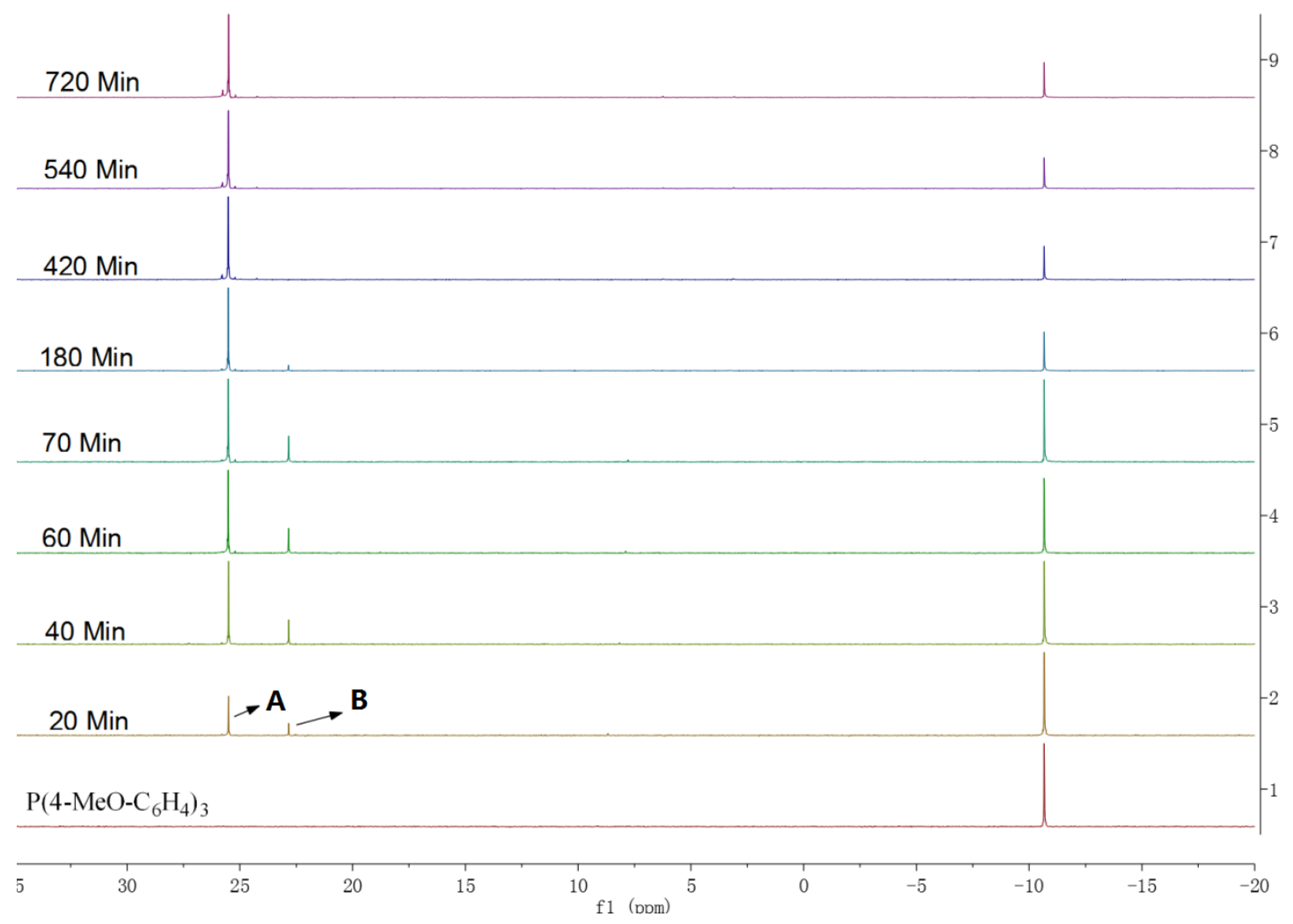

${ }^{1} \mathrm{H}$ NMR monitoring experiment

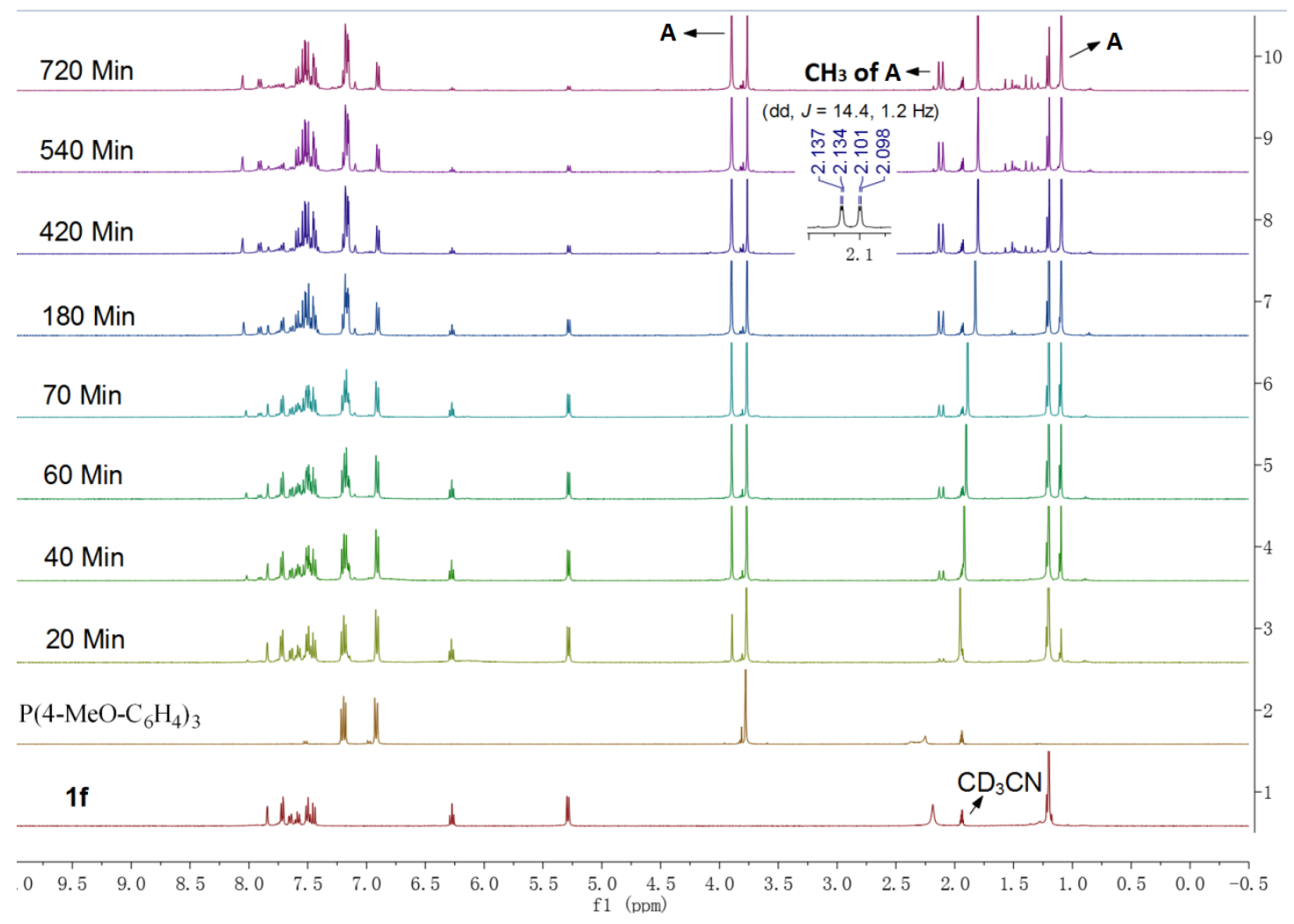


The NMR experiments clearly showed the addition of phosphine to central carbon atom of allene. After mixing $\mathbf{1 f}$ and $\mathrm{P}\left(4-\mathrm{MeO}-\mathrm{C}_{6} \mathrm{H}_{4}\right)_{3}$ in a NMR tube, vinyl phosphonium salt $\mathbf{A}$ was detected shortly in the ${ }^{31} \mathrm{P}$ NMR monitoring experiment. The process was also monitored by ${ }^{1} \mathrm{H}$ NMR spectroscopy. The assigned structure of $\mathbf{A}$ was consistent with the ${ }^{1} \mathrm{H}$ NMR data, two doublets for methyl group $\left(\mathrm{CH}_{3}, \delta 2.12\right.$ ppm, $\left.J_{\mathrm{P}-\mathrm{H}}=14.4\right)$. The vinyl phosphonium $\mathbf{A}$ was further confirmed by High Resolution MS analyses. We speculate that a resonance-stabilized zwitterionic phosphonium intermediate is formed, followed by protonation with acetic acid to generate $\mathbf{A}$ and $\mathbf{B}$.

\section{Hammett analysis through competition experiments}

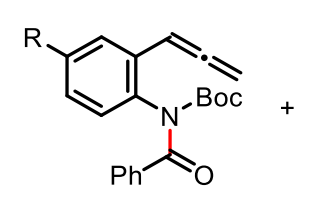

$1 \mathrm{~b}, 1 \mathrm{c}$ or $1 \mathrm{~g}$<smiles>C=Cc1ccccc1N(C)C(=O)c1ccccc1</smiles>

$1 \mathbf{a}$
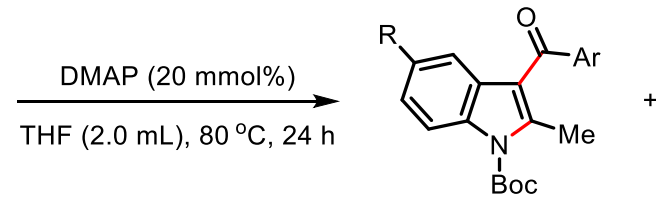

$\mathbf{2 b}, \mathbf{2 c}$ or $\mathbf{2 g}$

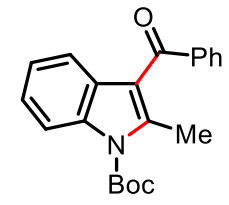

$2 \mathbf{a}$

To a $25 \mathrm{~mL}$ oven-dried Schlenk tube was added $\mathbf{1 a}(0.10 \mathrm{mmol}, 33.5 \mathrm{mg}), \mathbf{1 b}(0.1$ mmol, $34.9 \mathrm{mg})$, DMAP (0.02 mmol, $2.4 \mathrm{mg})$ a stir bar. The Schlenk tube was transferred into a $\mathrm{N}_{2}$-filled glovebox and added freshly distilled THF ( $\left.2 \mathrm{~mL}\right)$. The tube was then removed out from the glovebox and stirred at $80{ }^{\circ} \mathrm{C}$ for $24 \mathrm{~h}$. The mixture was concentrated under vacuum. The ratio $\mathbf{2 b} / \mathbf{2 a}$ was determined by ${ }^{1} \mathrm{H}$ NMR. Similar procedure is used to determine ratios $\mathbf{2 c} / \mathbf{2 a}$ and $\mathbf{2 g} / \mathbf{2 a}$. A plot of $\log \left(\mathrm{k}_{\mathrm{X}} / \mathrm{k}_{\mathrm{H}}\right)$ obtained in the formation of $\mathbf{2 a}, \mathbf{2 b}, \mathbf{2} \mathbf{c}, \mathbf{2} \mathbf{g}$ versus the corresponding para-position of aniline $\sigma_{\mathrm{p}}$ or meta-position of allenes $\sigma_{\mathrm{m}}$ values resulted in two Hammett plots.

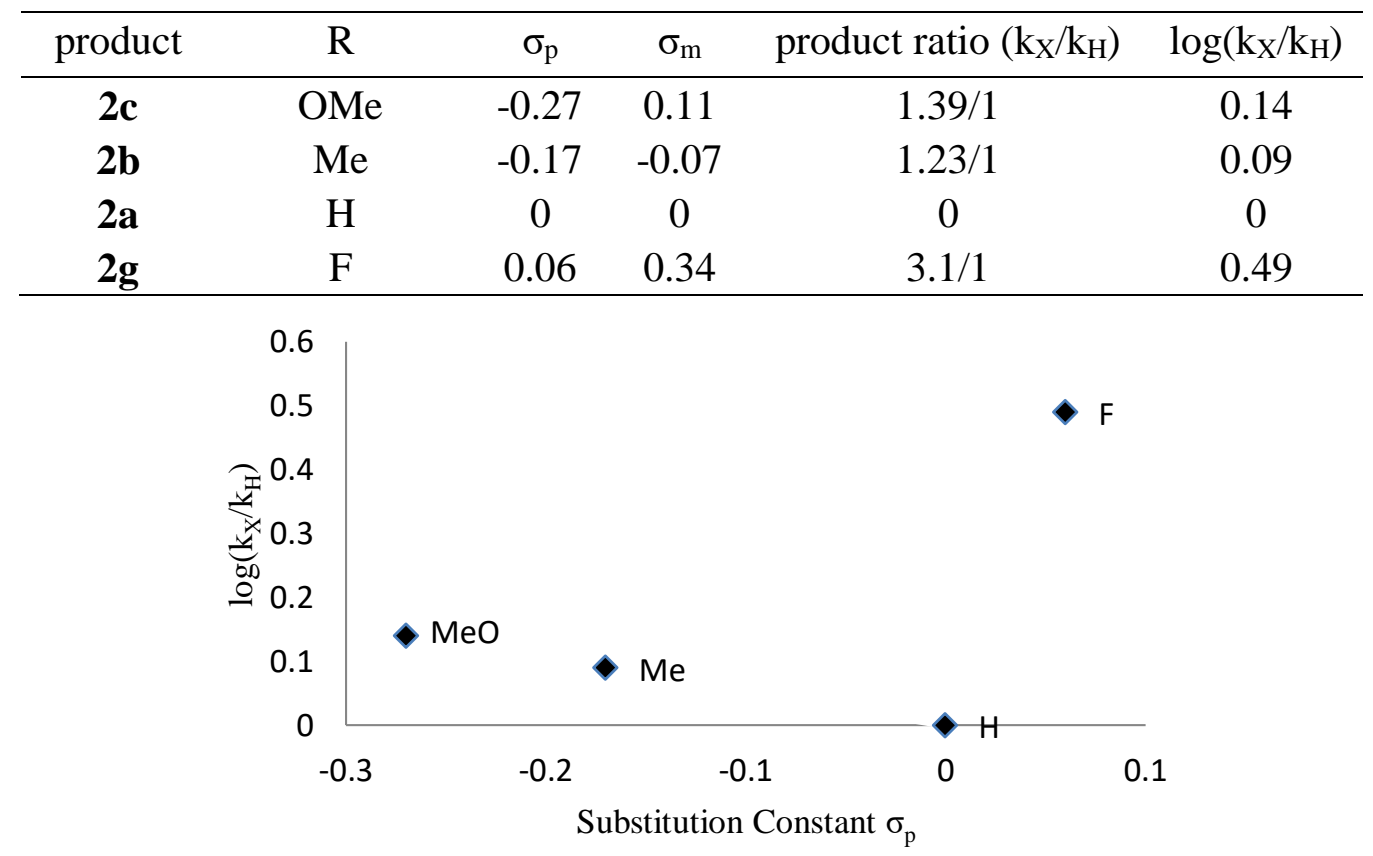

Figure S1. Hammet plot versus $\sigma_{\mathrm{p}}$ 


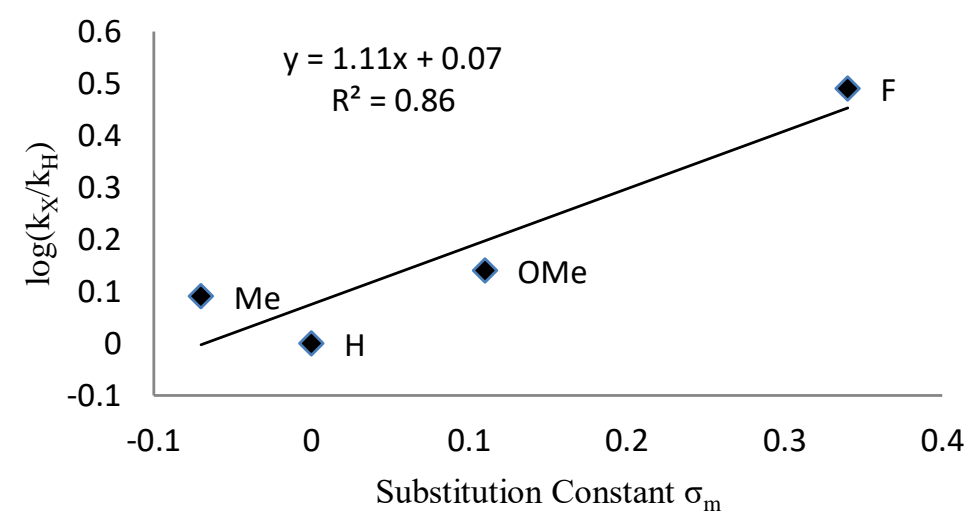

Figure S2. Hammet plot versus $\sigma_{\mathrm{m}}$<smiles>[R]c1ccc(C(=O)N(C(=O)C=C)c2ccccc2C=C)cc1</smiles>

$1 \mathrm{~m}, 1 \mathrm{n}, 1 \mathrm{p}$ or $1 \mathrm{r}$<smiles>CCCCN(C(=O)c1ccccc1)c1ccccc1</smiles>

1a<smiles>[R]c1ccc(C(=O)c2c(C)n(C(C)(C)C)c3ccccc23)cc1</smiles>

$2 m, 1 n, 1 p$ or $1 r$<smiles>Cc1c(C(=O)c2ccccc2)c2ccccc2n1C(C)(C)C</smiles>

2a

To a $25 \mathrm{~mL}$ oven-dried Schlenk tube was added $1 \mathrm{a}(0.10 \mathrm{mmol}, 33.5 \mathrm{mg}), \mathbf{1 m}(0.1$ mmol, $34.9 \mathrm{mg}$ ), DMAP (0.02 mmol, $2.4 \mathrm{mg}$ ) a stir bar. The Schlenk tube was transferred into a $\mathrm{N}_{2}$-filled glovebox and added freshly distilled THF $(2 \mathrm{~mL})$. The tube was then removed out from the glovebox and stirred at $80{ }^{\circ} \mathrm{C}$ for $24 \mathrm{~h}$. The mixture was concentrated under vacuum. The ratio $\mathbf{2 m} / \mathbf{2 a}$ was determined by ${ }^{1} \mathrm{H}$ NMR. Similar procedure is used to determine ratios $\mathbf{2 n} / \mathbf{2 a}, \mathbf{2} \mathbf{p} / \mathbf{2 a}$ and $\mathbf{2 r} / \mathbf{2 a}$. A plot of $\log \left(\mathrm{k}_{\mathrm{X}} / \mathrm{k}_{\mathrm{H}}\right)$ obtained in the formation of $\mathbf{2 a}, \mathbf{2 n}, \mathbf{2 m}, \mathbf{2} \mathbf{p}, \mathbf{2} \mathbf{r}$ versus the corresponding para-position of aroyl group $\sigma_{\mathrm{p}}$ resulted in one Hammett plots.

\begin{tabular}{ccccc}
\hline product & $\mathrm{R}$ & $\sigma_{\mathrm{p}}$ & product ratio $\left(\mathrm{kx}_{\mathrm{X}} / \mathrm{k}_{\mathrm{H}}\right)$ & $\log \left(\mathrm{k}_{\mathrm{X}} / \mathrm{k}_{\mathrm{H}}\right)$ \\
\hline $\mathbf{2 n}$ & $\mathrm{MeO}$ & -0.27 & $0.76 / 1$ & -0.12 \\
$\mathbf{2} \mathbf{m}$ & $\mathrm{Me}$ & -0.17 & $0.89 / 1$ & -0.05 \\
$\mathbf{2 a}$ & $\mathrm{H}$ & 0 & 0 & 0 \\
$\mathbf{2 r}$ & $\mathrm{F}$ & 0.06 & $0.64 / 1$ & -0.19 \\
$\mathbf{2} \mathbf{p}$ & $\mathrm{NO}_{2}$ & 0.78 & $1.61 / 1$ & 0.21 \\
\hline
\end{tabular}

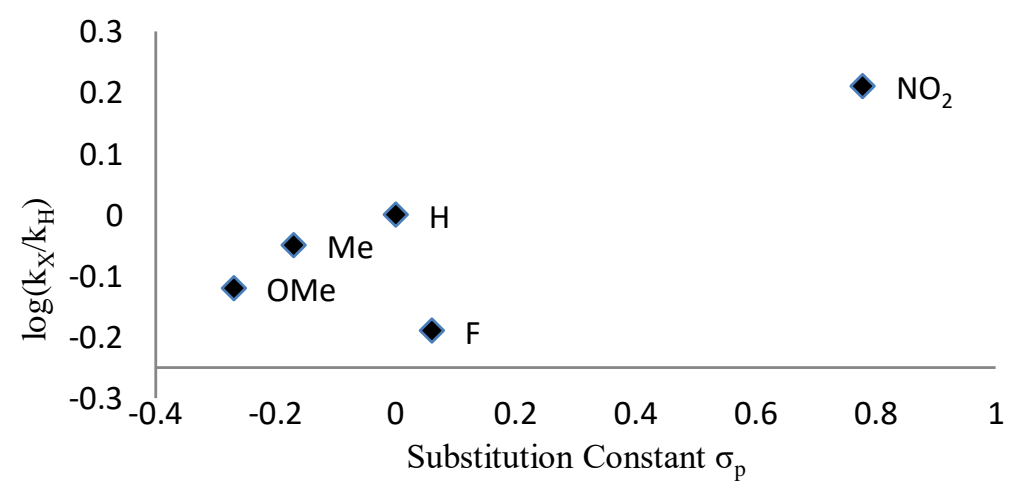

Figure S3. Hammet plot versus $\sigma_{\mathrm{p}}$ 
As shown above, no linear relationship was observed when the plot is derived from the para-position of aniline moiety $\sigma_{\mathrm{p}}$ values or the para-position of aroyl group $\sigma_{\mathrm{p}}$ values (Figure S1 and Figure S3). However, the plot that is derived from the meta-position of allenes $\sigma_{\mathrm{m}}$ values shows a good linear relationship (Figure S2). This positive relationship indicates that the electron-withdrawing group on the aryl ring of aniline is capable of stabilizing negative charge of the transition state in the rate determining step. Therefore, we think the rate determine step of this reaction may be the addition of the DMAP to allene moiety.

\section{Lewis base-catalyzed $\boldsymbol{\gamma}$-additions of sulfonamide with allenes}

To gain insight into the inherent distinction between weakly activated allenes and activated allenes bearing an electron-withdrawing group in Lewis base catalysis, we performed experiments to compare the reactivity of different allenes though $\gamma$-addition reaction with sulfonamide $\left(\mathrm{TsNH}_{2}\right)$.

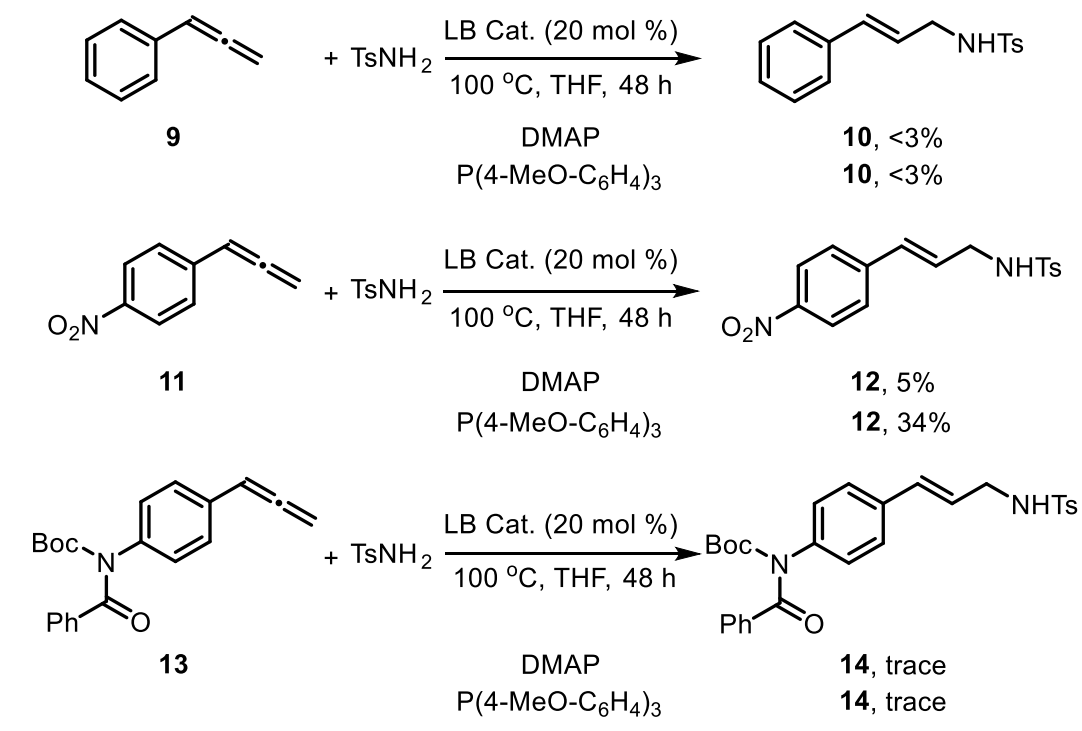

To a $25 \mathrm{~mL}$ oven-dried Schlenk tube was added allene $(0.10 \mathrm{mmol}), \mathrm{TsNH}_{2}(0.15$ mmol) and a stir bar. The Schlenk tube was transferred into a $\mathrm{N}_{2}$-filled glovebox and added Lewis base $(0.02 \mathrm{mmol})$, freshly distilled THF $(1 \mathrm{~mL})$. The tube was then removed out from the glovebox and stirred at $100{ }^{\circ} \mathrm{C}$ for $48 \mathrm{~h}$. The resulting mixture was concentrated under vacuum and purified by flash column chromatography on silica gel to give yellow solid 12 or was detected by GC-MS and crude ${ }^{1} \mathrm{H}$ NMR spectrum. The NMR data of the product 12: ${ }^{1} \mathrm{H} \mathrm{NMR}\left(400 \mathrm{MHz}, \mathrm{CDCl}_{3}\right) \delta 8.13(\mathrm{~d}, J$ $=8.8 \mathrm{~Hz}, 2 \mathrm{H}), 7.79(\mathrm{~d}, J=8.0 \mathrm{~Hz}, 2 \mathrm{H}), 7.36(\mathrm{~d}, J=8.8 \mathrm{~Hz}, 2 \mathrm{H}), 7.31(\mathrm{~d}, J=8.0 \mathrm{~Hz}$, $2 \mathrm{H}), 6.54(\mathrm{~d}, J=16.0 \mathrm{~Hz}, 1 \mathrm{H}), 6.23(\mathrm{~m}, 1 \mathrm{H}), 3.80(\mathrm{t}, J=6.4 \mathrm{~Hz}, 2 \mathrm{H}), 2.41(\mathrm{~s}, 3 \mathrm{H})$. ${ }^{13} \mathrm{C}$ NMR $\left(100 \mathrm{MHz}, \mathrm{CDCl}_{3}\right) \delta 147.1,143.7,142.6,136.9,130.5,129.8,129.4,127.2$, $126.9,123.9,45.0,21.5$. The data of compound $\mathbf{1 2}$ are consistent with the reported literature $^{4}$ 


\section{Substrate Preparation}

All of $N$-Boc-2-iodoanilines was purchased commercially or prepared by reported literature method. ${ }^{5}$

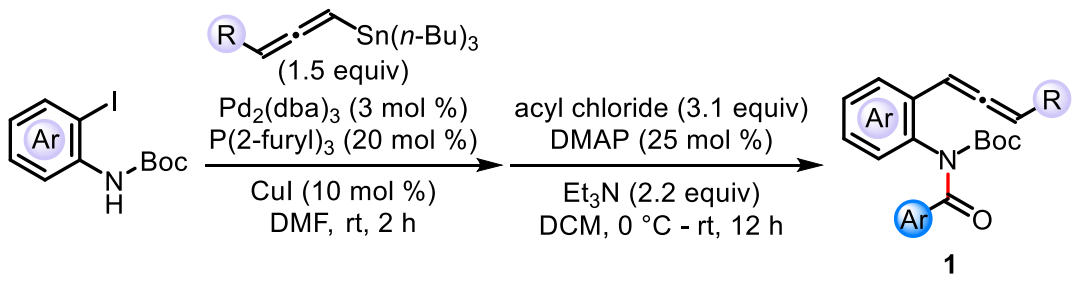

The solution of $\mathrm{N}$-Boc-2-iodoanilines (1.0 equiv) and allenyltributyltin (1.5 equiv) in anhydrous DMF $(0.125 \mathrm{M})$ was degassed and purged with nitrogen. $\mathrm{Pd}_{2}(\mathrm{dba})_{3}(3$ mol \%), $\mathrm{P}(2 \text {-furyl })_{3}(20 \mathrm{~mol} \%)$, and $\mathrm{CuI}(10 \mathrm{~mol} \%)$ were added to the reaction mixture at room temperature (rt) under argon atmosphere. The reaction mixture was stirred at $\mathrm{rt}$ for $2 \mathrm{~h}$, quenched by addition of $10 \%$ aqueous amonium solution and extracted with diethyl ether. The combined extractions were washed with water, brine, dried over anhydrous sodium sulfate and evaporated to get the residues without further purification. Then, to a solution of the crude material in DCM $(0.4 \mathrm{M})$ was added $\mathrm{Et}_{3} \mathrm{~N}$ (2.2 equiv), DMAP ( $25 \mathrm{~mol} \%$ ), and acyl chloride ( 3.1 equiv) at $0{ }^{\circ} \mathrm{C}$. The mixture was stirred at $\mathrm{rt}$ overnight. The mixture was evaporated to get the crude product, which was purified by flash silica gel chromatography with petroleum ether/ethyl acetate to give $\mathbf{1 a} \sim \mathbf{1 k}$.

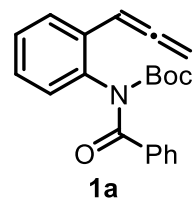

$N$-Boc- $N$-benzoyl-2-allenylaniline (1a). According to the general procedure, 1a was synthesized with $N$-Boc-2-iodoaniline ( $3 \mathrm{mmol}, 957.0 \mathrm{mg}$ ). Purified by flash column chromatography on silica gel (PE : EA $=40: 1)$ to give 1a as a light yellow solid (753.8 mg, $75 \%$ yield). ${ }^{1} \mathrm{H}$ NMR $\left(400 \mathrm{MHz}, \mathrm{CDCl}_{3}\right) \delta 7.72(\mathrm{~d}, J=7.6 \mathrm{~Hz}, 2 \mathrm{H}), 7.52(\mathrm{dd}, J=$ 8.8, $8.4 \mathrm{~Hz}, 2 \mathrm{H}), 7.44(\mathrm{dd}, J=7.6,7.6 \mathrm{~Hz} 2 \mathrm{H}), 7.33(\mathrm{dd}, J=7.6,7.6 \mathrm{~Hz} 1 \mathrm{H}), 7.28-$ $7.25(\mathrm{~m}, 1 \mathrm{H}), 7.19(\mathrm{~d}, J=7.8 \mathrm{~Hz}, 1 \mathrm{H}), 6.28(\mathrm{t}, J=6.8 \mathrm{~Hz}, 1 \mathrm{H}), 5.16(\mathrm{~d}, J=6.8 \mathrm{~Hz}, 2 \mathrm{H})$, $1.23(\mathrm{~s}, 9 \mathrm{H}) .{ }^{13} \mathrm{C}$ NMR $\left(100 \mathrm{MHz}, \mathrm{CDCl}_{3}\right) \delta 210.7,172.1,153.0,136.6,136.1,132.2$, 131.5, 129.1, 128.6, 128.2, 128.1, 128.0, 127.7, 89.1, 83.5, 78.8, 27.4. HRMS (ESI): Calcd for $\left[\mathrm{C}_{21} \mathrm{H}_{22} \mathrm{NO}_{3}\right]^{+}[\mathrm{M}+\mathrm{H}]^{+}$336.1594, Found 336.1603.<smiles>C/C=C\c1cc(C)ccc1N([14CH3])C(=O)c1ccccc1</smiles>

$N$-Boc- $N$-benzoyl-2-allenyl-4-methylaniline (1b). According to the general procedure, 1b was synthesized with $N$-Boc-2-iodo-4-methylaniline (3.7 mmol, 1.2412 g). Purified by flash column chromatography on silica gel $(\mathrm{PE}: \mathrm{EA}=50: 1)$ to give 
1b as a light yellow oil (996.5 mg, 77\% yield). ${ }^{1} \mathrm{H} \mathrm{NMR}\left(400 \mathrm{MHz}, \mathrm{CDCl}_{3}\right) \delta 7.70(\mathrm{~d}$, $J=7.2 \mathrm{~Hz}, 2 \mathrm{H}), 7.49(\mathrm{t}, J=7.2 \mathrm{~Hz}, 1 \mathrm{H}), 7.42(\mathrm{dd}, J=6.8,7.2 \mathrm{~Hz}, 2 \mathrm{H}), 7.32(\mathrm{~s}, 1 \mathrm{H})$, 7.06 (brs, 2H), 6.24 (t, $J=6.6 \mathrm{~Hz}, 1 \mathrm{H}), 5.14(\mathrm{~d}, J=6.8 \mathrm{~Hz}, 1 \mathrm{H}), 2.34(\mathrm{~s}, 3 \mathrm{H}), 1.22$ (s, 9H). ${ }^{13} \mathrm{C} \mathrm{NMR}\left(100 \mathrm{MHz}, \mathrm{CDCl}_{3}\right) \delta 210.5,172.2,153.1,138.4,136.7,133.5,131.56$, 131.4, 128.7, 128.7, 128.5, 128.1, 127.9, 89.0, 83.4, 78.8, 27.4, 21.1. HRMS (ESI): Calcd for $\left[\mathrm{C}_{22} \mathrm{H}_{24} \mathrm{NO}_{3}\right]^{+}[\mathrm{M}+\mathrm{H}]^{+} 350.1751$, Found 350.1744 .

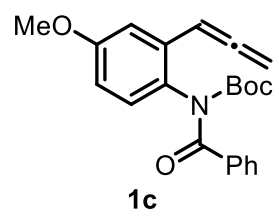

$\boldsymbol{N}$-Boc- $\boldsymbol{N}$-benzoyl-2-allenyl-4-methoxyaniline (1c). According to the general procedure, 1c was synthesized with $\mathrm{N}$-Boc-2-iodo-4-methoxyaniline $(3.2 \mathrm{mmol}$, $1.1242 \mathrm{~g})$. Purified by flash column chromatography on silica gel (PE : EA = $30: 1)$ to give 1c as a yellow solid $\left(742.6 \mathrm{mg}, 64 \%\right.$ yield). ${ }^{1} \mathrm{H}$ NMR $\left(400 \mathrm{MHz}, \mathrm{CDCl}_{3}\right) \delta$ $7.71-7.69(\mathrm{~m}, 2 \mathrm{H}), 7.51(\mathrm{dd}, J=7.6,7.2 \mathrm{~Hz}, 1 \mathrm{H}), 7.43(\mathrm{dd}, J=7.6,7.2 \mathrm{~Hz}, 2 \mathrm{H})$, $7.10(\mathrm{~d}, J=8.8 \mathrm{~Hz}, 1 \mathrm{H}), 7.04(\mathrm{~d}, J=2.6 \mathrm{~Hz}, 1 \mathrm{H}), 6.81(\mathrm{dd}, J=8.8,2.6 \mathrm{~Hz}, 1 \mathrm{H}), 6.24$ $(\mathrm{dd}, J=6.8,6.8 \mathrm{~Hz}, 1 \mathrm{H}), 5.17(\mathrm{~d}, J=6.8 \mathrm{~Hz}, 2 \mathrm{H}), 3.81(\mathrm{~s}, 3 \mathrm{H}), 1.22(\mathrm{~s}, 9 \mathrm{H}) .{ }^{13} \mathrm{C}$ NMR $\left(100 \mathrm{MHz}, \mathrm{CDCl}_{3}\right) \delta 210.5,172.3,159.3,153.2,136.7,133.2,131.4,130.0$, 129.0, 128.1, 127.9, 113.9, 112.3, 89.2, 83.4, 79.1, 55.4, 27.4. HRMS (ESI): Calcd for $\left[\mathrm{C}_{22} \mathrm{H}_{24} \mathrm{NO}_{4}\right]^{+}[\mathrm{M}+\mathrm{H}]^{+}$366.1700, Found 366.1699.

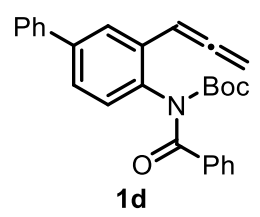

$N$-Boc- $N$-benzoyl-2-allenyl-4-phenylaniline (1d). According to the general procedure, 1d was synthesized with $N$-Boc-2-iodo-4-phenylaniline (0.82 mmol, 325.9 $\mathrm{mg})$. Purified by flash column chromatography on silica gel $(\mathrm{PE}: \mathrm{EA}=60: 1)$ to give 1d as a white solid (193.8 mg, $57 \%$ yield). ${ }^{1} \mathrm{H}$ NMR $\left(400 \mathrm{MHz}, \mathrm{CDCl}_{3}\right) \delta 7.75-7.73$ $(\mathrm{m}, 3 \mathrm{H}), 7.63-7.55(\mathrm{~m}, 2 \mathrm{H}), 7.54-7.50(\mathrm{~m}, 1 \mathrm{H}), 7.48-7.42(\mathrm{~m}, 5 \mathrm{H}), 7.37-7.33$ $(\mathrm{m}, 1 \mathrm{H}), 7.26(\mathrm{dd}, J=8.0,2.0 \mathrm{~Hz}, 1 \mathrm{H}), 6.33(\mathrm{td}, J=6.8,2.6 \mathrm{~Hz}, 1 \mathrm{H}), 5.19(\mathrm{~d}, J=6.4$ $\mathrm{Hz}, 2 \mathrm{H}), 1.24$ (s, 9H). ${ }^{13} \mathrm{C} \mathrm{NMR}\left(100 \mathrm{MHz}, \mathrm{CDCl}_{3}\right) \delta 210.7,172.1,153.01,141.6$, $140.4,136.7,135.3,132.4,131.6,129.4,128.7,128.2$, 128.0, 127.5, 127.2, 126.9, 126.6, 89.2, 83.7, 79.0, 27.4. HRMS (ESI): Calcd for $\left[\mathrm{C}_{27} \mathrm{H}_{26} \mathrm{NO}_{3}\right]^{+}[\mathrm{M}+\mathrm{H}]^{+} 412.1907$, Found 412.1915.<smiles>C/C=C\c1cc(C(F)(F)F)ccc1N(C)C(=O)c1ccccc1</smiles>

$N$-Boc- $N$-benzoyl-2-allenyl-4-(trifluoromethyl)aniline (1e). According to the general procedure, 1e was synthesized with $N$-Boc-2-iodo-4-(trifluoromethyl)aniline (2.3 mmol, $883.3 \mathrm{mg}$ ). Purified by flash column chromatography on silica gel (PE : 
$\mathrm{EA}=20: 1)$ to give 1e as a white solid $\left(717.2 \mathrm{mg}, 78 \%\right.$ yield). ${ }^{1} \mathrm{H}$ NMR $(400 \mathrm{MHz}$, $\left.\mathrm{CDCl}_{3}\right) \delta 7.79(\mathrm{~s}, 1 \mathrm{H}), 7.73(\mathrm{~d}, J=7.2 \mathrm{~Hz}, 2 \mathrm{H}), 7.63-7.43(\mathrm{~m}, 4 \mathrm{H}), 7.32(\mathrm{~d}, J=8.0$ $\mathrm{Hz}, 1 \mathrm{H}), 6.28(\mathrm{t}, J=6.4 \mathrm{~Hz}, 1 \mathrm{H}), 5.25(\mathrm{~d}, J=6.4 \mathrm{~Hz}, 2 \mathrm{H}), 1.23(\mathrm{~s}, 9 \mathrm{H}) .{ }^{13} \mathrm{C} \mathrm{NMR}$ $\left(100 \mathrm{MHz}, \mathrm{CDCl}_{3}\right) \delta 210.8,171.8,152.50,143.3,138.9,136.1,133.5,130.8$ (q, $J=$ $32.7 \mathrm{~Hz}), 130.5,129.8,129.0,128.3,128.1,125.2$ (q, $J=3.8 \mathrm{~Hz}), 123.7$ (q, $J=270.9$ $\mathrm{Hz}), 124.3(\mathrm{q}, J=3.5 \mathrm{~Hz}), 88.6,84.2,79.8,27.4$. HRMS (ESI): Calcd for $\left[\mathrm{C}_{22} \mathrm{H}_{21} \mathrm{~F}_{3} \mathrm{NO}_{3}\right]^{+}[\mathrm{M}+\mathrm{H}]^{+}$404.1468, Found 404.1467.

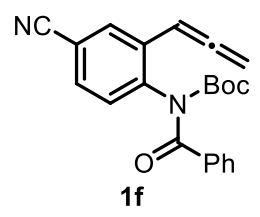

$N$-Boc- $N$-benzoyl-2-allenyl-4-cyanideaniline (1f). According to the general procedure, $\mathbf{1 f}$ was synthesized with $N$-Boc-2-iodo-4-cyanideaniline (1.6 mmol, 559.0 $\mathrm{mg}$ ). Purified by flash column chromatography on silica gel ( $\mathrm{PE}: \mathrm{EA}=10: 1)$ to give 1f as a white solid (362.4 mg, 63\% yield). ${ }^{1} \mathrm{H} \mathrm{NMR}\left(400 \mathrm{MHz}, \mathrm{CDCl}_{3}\right) \delta 7.84(\mathrm{~s}, 1 \mathrm{H})$, $7.72(\mathrm{~d}, J=7.2 \mathrm{~Hz}, 2 \mathrm{H}), 7.59-7.53(\mathrm{~m}, 2 \mathrm{H}), 7.47(\mathrm{dd}, J=6.8,6.8 \mathrm{~Hz}, 2 \mathrm{H}), 7.30(\mathrm{~d}, J$ $=8.0 \mathrm{~Hz}, 1 \mathrm{H}), 6.24(\mathrm{t}, J=6.8 \mathrm{~Hz}, 1 \mathrm{H}), 5.28(\mathrm{~d}, J=6.4 \mathrm{~Hz}, 2 \mathrm{H}), 1.24(\mathrm{~s}, 9 \mathrm{H}) .{ }^{13} \mathrm{C}$ NMR $\left(100 \mathrm{MHz}, \mathrm{CDCl}_{3}\right) \delta 210.9,171.6,152.2,139.9,135.8,134.3,132.1,130.7$, 130.3, 128.3, 128.1, 118.1, 112.7, 88.1, 84.5, 80.0, 27.4. HRMS (ESI): Calcd for $\left[\mathrm{C}_{22} \mathrm{H}_{20} \mathrm{~N}_{2} \mathrm{O}_{3} \mathrm{Na}\right]^{+}[\mathrm{M}+\mathrm{Na}]^{+}$383.1366, Found 383.1362.

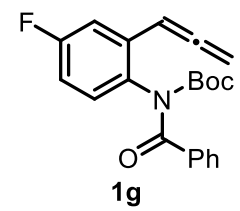

$N$-Boc- $N$-benzoyl-2-allenyl-4-fluoroaniline (1g). According to the general procedure, $1 \mathrm{~g}$ was synthesized with $N$-Boc-4-fluoro-2-iodoaniline $(1.6 \mathrm{mmol}, 559.0 \mathrm{mg})$. Purified by flash column chromatography on silica gel $(\mathrm{PE}: \mathrm{EA}=60: 1)$ to give $\mathbf{1 g}$ as a yellow oil (1.1106 g, 78\% yield). ${ }^{1} \mathrm{H} \mathrm{NMR}\left(400 \mathrm{MHz}, \mathrm{CDCl}_{3}\right) \delta 7.72-7.70(\mathrm{~m}$, 2H), $7.53(\mathrm{dd}, J=7.6,7.2 \mathrm{~Hz}, 1 \mathrm{H}), 7.44(\mathrm{dd}, J=7.6,7.2 \mathrm{~Hz}, 2 \mathrm{H}), 7.23$ (dd, $J=9.6$, $2.8 \mathrm{~Hz}, 1 \mathrm{H}), 7.17(\mathrm{dd}, J=8.8,5.2 \mathrm{~Hz}, 1 \mathrm{H}), 6.96(\mathrm{td}, J=8.4,2.8 \mathrm{~Hz}, 1 \mathrm{H}), 6.23(\mathrm{t}, J=$ $6.8 \mathrm{~Hz}, 1 \mathrm{H}), 5.20(\mathrm{~d}, J=6.8 \mathrm{~Hz}, 2 \mathrm{H}), 1.22(\mathrm{~s}, 9 \mathrm{H}) .{ }^{13} \mathrm{C} \mathrm{NMR}\left(100 \mathrm{MHz}, \mathrm{CDCl}_{3}\right) \delta$ 210.6, 172.1, $162.3(\mathrm{~d}, J=245.6 \mathrm{~Hz}), 152.8,136.3,134.6(\mathrm{~d}, J=8.7 \mathrm{~Hz}), 131.8(\mathrm{~d}, J$ $=2.5 \mathrm{~Hz}), 131.7,130.0(\mathrm{~d}, J=8.9 \mathrm{~Hz}), 128.2,127.9,114.8(\mathrm{~d}, J=23.1 \mathrm{~Hz}), 114.2(\mathrm{~d}$, $J=23.9 \mathrm{~Hz}), 88.7,83.8,79.5,27.3$. HRMS (ESI): Calcd for $\left[\mathrm{C}_{21} \mathrm{H}_{21} \mathrm{FNO}_{3}\right]^{+}[\mathrm{M}+\mathrm{H}]^{+}$ 354.1500, Found 354.1508.

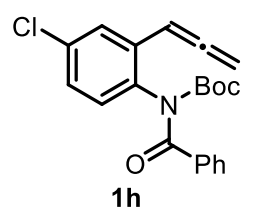

$N$-Boc- $N$-benzoyl-2-allenyl-4-chloroaniline (1h). According to the general procedure, $\mathbf{1 h}$ was synthesized with $N$-Boc-4-chloro-2-iodoaniline (2.2 mmol, 762.8 
mg). Purified by flash column chromatography on silica gel (PE : EA $=50: 1)$ to give $1 \mathrm{~g}$ as a yellow oil $\left(534.5 \mathrm{mg}, 66 \%\right.$ yield). ${ }^{1} \mathrm{H}$ NMR $\left(400 \mathrm{MHz}, \mathrm{CDCl}_{3}\right) \delta 7.71(\mathrm{~d}, J=$ $6.0 \mathrm{~Hz}, 2 \mathrm{H}), 7.53-7.45(\mathrm{~m}, 4 \mathrm{H}), 7.24(\mathrm{dd}, J=8.0,6.8 \mathrm{~Hz}, 1 \mathrm{H}), 7.12(\mathrm{~d}, J=8.0 \mathrm{~Hz}$, $1 \mathrm{H}), 6.21(\mathrm{t}, J=5.2 \mathrm{~Hz}, 1 \mathrm{H}), 5.22(\mathrm{~d}, J=5.2 \mathrm{~Hz}, 2 \mathrm{H}), 1.23(\mathrm{~s}, 9 \mathrm{H}) .{ }^{13} \mathrm{C}$ NMR $(100$ $\left.\mathrm{MHz}, \mathrm{CDCl}_{3}\right) \delta 210.7,172.0,152.7,136.2,134.4,134.1,131.8,130.4,128.2,128.0$, 127.8, 127.8, 88.4, 83.9, 79.6, 27.4. HRMS (ESI): Calcd for $\left[\mathrm{C}_{21} \mathrm{H}_{20} \mathrm{ClNO}_{3} \mathrm{Na}\right]^{+}$ $[\mathrm{M}+\mathrm{Na}]^{+}$392.1024, Found 392.1017.<smiles>C=Cc1ccc(C)cc1N(C(=O)C(=O)c1ccccc1)C(=O)c1ccccc1</smiles>

$N$-Boc- $N$-benzoyl-2-allenyl-5-methylaniline (1i). According to the general procedure, 1i was synthesized with $N$-Boc-2-iodo-5-methylaniline (4.1 mmol, 1.3801 g). Purified by flash column chromatography on silica gel (PE : EA $=50: 1)$ to give 1i as a yellow solid (991.2 mg, 69\% yield). ${ }^{1} \mathrm{H}$ NMR (400 MHz, $\left.\mathrm{CDCl}_{3}\right) \delta 7.76-7.68$ $(\mathrm{m}, 2 \mathrm{H}), 7.53-7.49(\mathrm{~m}, 1 \mathrm{H}), 7.45-7.40(\mathrm{~m}, 3 \mathrm{H}), 7.13(\mathrm{~d}, J=8.0 \mathrm{~Hz}, 1 \mathrm{H}), 7.00(\mathrm{~s}$, $1 \mathrm{H}), 6.23(\mathrm{t}, J=6.8 \mathrm{~Hz}, 1 \mathrm{H}), 5.12(\mathrm{~d}, J=6.8 \mathrm{~Hz}, 2 \mathrm{H}), 2.33(\mathrm{~s}, 3 \mathrm{H}), 1.22(\mathrm{~s}, 9 \mathrm{H}) .{ }^{13} \mathrm{C}$ NMR $\left(100 \mathrm{MHz}, \mathrm{CDCl}_{3}\right) \delta 210.5,172.1,153.0,137.8,136.8,135.9,131.5,129.6$, 129.5, 129.1, 128.2, 128.0, 89.0, 83.4, 78.6, 27.4, 20.9. HRMS (ESI): Calcd for $\left[\mathrm{C}_{22} \mathrm{H}_{24} \mathrm{NO}_{3}\right]^{+}[\mathrm{M}+\mathrm{H}]^{+}$350.1751, Found 350.1760.

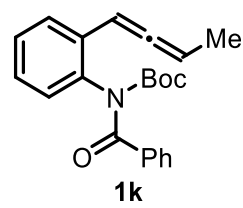

$N$-Boc- $N$-benzoyl-2-(3'-methylallenyl)aniline (1k). According to the general procedure, 1k was synthesized with $N$-Boc-2-iodoaniline $(3.0 \mathrm{mmol}, 957.3 \mathrm{mg}$ ). Purified by flash column chromatography on silica gel (PE : EA = 30:1) to give $\mathbf{1 k}$ as a yellow solid (582.2 $\mathrm{mg}, 56 \%$ yield). ${ }^{1} \mathrm{H} \mathrm{NMR}\left(400 \mathrm{MHz}, \mathrm{CDCl}_{3}\right) \delta 7.72(\mathrm{~d}, J=$ $7.2 \mathrm{~Hz}, 2 \mathrm{H}), 7.53-7.49(\mathrm{~m}, 2 \mathrm{H}), 7.43(\mathrm{dd}, J=7.6,7.2 \mathrm{~Hz}, 2 \mathrm{H}), 7.31$ (ddd, $J=7.2$, 7.6, $0.8 \mathrm{~Hz}, 1 \mathrm{H}), 7.25-7.21(\mathrm{~m}, 1 \mathrm{H}), 7.16(\mathrm{dd}, J=8.0,0.8 \mathrm{~Hz}, 1 \mathrm{H}), 6.21(\mathrm{dq}, J=6.0$, $2.8 \mathrm{~Hz}, 1 \mathrm{H}), 5.58-5.51(\mathrm{~m}, 1 \mathrm{H}), 1.77(\mathrm{dd}, J=7.2,3.2 \mathrm{~Hz}, 3 \mathrm{H}), 1.23(\mathrm{~s}, 9 \mathrm{H}) .{ }^{13} \mathrm{C}$ NMR $\left(100 \mathrm{MHz}, \mathrm{CDCl}_{3}\right) \delta 207.1,172.1,153.0,143.3,136.7,136.0,133.1,131.5$, 129.0, 128.5, 128.1, 128.0, 127.5, 89.7, 89.1, 83.4, 27.4, 13.8. HRMS (ESI): Calcd for $\left[\mathrm{C}_{22} \mathrm{H}_{23} \mathrm{NO}_{3} \mathrm{Na}\right]^{+}[\mathrm{M}+\mathrm{Na}]^{+}$372.1570, Found 372.1573.

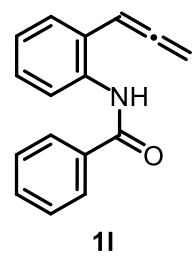

$N$-benzoyl-2-allenylaniline (11). According to the general procedure, 11 was synthesized with $N$-benzoyl-2-iodoaniline $(3.0 \mathrm{mmol}, 969.3 \mathrm{mg})$. Purified by flash 
column chromatography on silica gel $(\mathrm{PE}: \mathrm{EA}=30: 1)$ to give $\mathbf{1 l}$ as a white solid (600.0 mg, 85\% yield). ${ }^{1} \mathrm{H}$ NMR $\left(400 \mathrm{MHz}, \mathrm{CDCl}_{3}\right) \delta 8.53(\mathrm{~s}, 1 \mathrm{H}), 8.14(\mathrm{~d}, J=8.0$ $\mathrm{Hz}, 1 \mathrm{H}), 7.88(\mathrm{~d}, J=7.6 \mathrm{~Hz}, 2 \mathrm{H}), 7.56(\mathrm{t}, J=7.6 \mathrm{~Hz}, 1 \mathrm{H}), 7.49$ (dd, $J=6.8,8.0 \mathrm{~Hz}$, 2H), $7.32-7.28(\mathrm{~m}, 2 \mathrm{H}), 7.15(\mathrm{dd}, J=7.2,6.8 \mathrm{~Hz}, 1 \mathrm{H}), 6.34(\mathrm{t}, J=6.8 \mathrm{~Hz}, 1 \mathrm{H}), 5.14$ $(\mathrm{d}, J=6.8 \mathrm{~Hz}, 2 \mathrm{H}) .{ }^{13} \mathrm{C} \mathrm{NMR}\left(100 \mathrm{MHz}, \mathrm{CDCl}_{3}\right) \delta 209.9,165.8,135.4,134.9,131.8$, 129.1, 128.6, 128.0, 127.2, 125.0, 124.0, 123.4, 91.2, 78.8. HRMS (ESI): Calcd for $\left[\mathrm{C}_{16} \mathrm{H}_{14} \mathrm{NO}\right]^{+}[\mathrm{M}+\mathrm{H}]^{+}$236.1070, Found 236.1075.<smiles>C=Cc1ccccc1N([14CH3])C(=O)c1ccc(C)cc1</smiles>

$N$-Boc- $N$-(4-(methyl)benzoyl)-2-allenylaniline (1m). According to the general procedure, 1m was synthesized with $N$-Boc-2-iodoaniline $(3.0 \mathrm{mmol}, 957.3 \mathrm{mg}$ ). Purified by flash column chromatography on silica gel (PE : EA = 50:1) to give $\mathbf{1 m}$ as a yellow solid $\left(650.2 \mathrm{mg}, 62 \%\right.$ yield). ${ }^{1} \mathrm{H} \mathrm{NMR}\left(400 \mathrm{MHz}, \mathrm{CDCl}_{3}\right) \delta 7.63(\mathrm{~d}, J=$ $7.6 \mathrm{~Hz}, 2 \mathrm{H}), 7.52(\mathrm{~d}, J=7.6 \mathrm{~Hz}, 1 \mathrm{H}), 7.31(\mathrm{dd}, J=7.6,7.6 \mathrm{~Hz}, 1 \mathrm{H}), 7.23-7.22(\mathrm{~m}$, $3 \mathrm{H}), 7.16(\mathrm{~d}, J=7.8 \mathrm{~Hz}, 1 \mathrm{H}), 6.28(\mathrm{t}, J=6.8 \mathrm{~Hz}, 1 \mathrm{H}), 5.15(\mathrm{~d}, J=6.8 \mathrm{~Hz}, 2 \mathrm{H}), 2.40$ $(\mathrm{s}, 3 \mathrm{H}), 1.26(\mathrm{~s}, 9 \mathrm{H}) .{ }^{13} \mathrm{C} \mathrm{NMR}\left(100 \mathrm{MHz}, \mathrm{CDCl}_{3}\right) \delta 210.6,172.0,153.1,142.2,136.3$, 133.5, 132.2, 129.0, 128.8, 128.4, 128.3, 128.0, 127.7, 89.1, 83.3, 78.7, 27.5, 21.6. HRMS (ESI): Calcd for $\left[\mathrm{C}_{22} \mathrm{H}_{23} \mathrm{NO}_{3} \mathrm{Na}\right]^{+}[\mathrm{M}+\mathrm{Na}]^{+} 372.1570$, Found 372.1565 .<smiles>C/C=C\c1ccccc1N([14CH3])C(=O)c1ccc(OC)cc1</smiles>

$N$-Boc- $N$-(4-(methoxyl)benzoyl)-2-allenylaniline (1n). According to the general procedure, 1n was synthesized with $N$-Boc-2-iodoaniline $(1.5 \mathrm{mmol}, 0.4787 \mathrm{~g})$. Purified by flash column chromatography on silica gel (PE : EA $=20: 1)$ to give 1n as a white solid (383.5 mg, 70\% yield). ${ }^{1} \mathrm{H}$ NMR (400 MHz, $\left.\mathrm{CDCl}_{3}\right) \delta 7.72(\mathrm{~d}, J=8.8$ $\mathrm{Hz}, 2 \mathrm{H}), 7.52(\mathrm{~d}, J=7.6 \mathrm{~Hz}, 1 \mathrm{H}), 7.30(\mathrm{dd}, J=7.6,7.2 \mathrm{~Hz}, 1 \mathrm{H}), 7.25-7.21(\mathrm{~m}, 1 \mathrm{H})$, $7.15(\mathrm{~d}, J=7.8 \mathrm{~Hz}, 1 \mathrm{H}), 6.92(\mathrm{~d}, J=8.8 \mathrm{~Hz}, 2 \mathrm{H}), 6.29(\mathrm{t}, J=6.8 \mathrm{~Hz}, 1 \mathrm{H}), 5.15(\mathrm{~d}, J=$ $6.8 \mathrm{~Hz}, 2 \mathrm{H}), 3.84(\mathrm{~s}, 3 \mathrm{H}), 1.29$ (s, 9H). ${ }^{13} \mathrm{C} \mathrm{NMR}\left(100 \mathrm{MHz}, \mathrm{CDCl}_{3}\right) \delta 210.6,171.4$, 162.5, 153.2, 136.4, 132.1, 130.6, 129.0, 128.3, 128.3, 128.0, 127.6, 113.4, 89.1, 83.1, 78.8, 55.4, 27.5. HRMS (ESI): Calcd for $\left[\mathrm{C}_{22} \mathrm{H}_{24} \mathrm{NO}_{4}\right]^{+}[\mathrm{M}+\mathrm{H}]^{+} 366.1700$, Found 366.1701 .<smiles>CCOc1ccccc1N(C)C(=O)c1ccc(C(C)=O)cc1</smiles> 
$N$-Boc- $N$-(4-(methoxycarbonyl)benzoyl)-2-allenylaniline (10). According to the general procedure, 1o was synthesized with $N$-Boc-2-iodoaniline $(3.0 \mathrm{mmol}, 957.3$ $\mathrm{mg})$. Purified by flash column chromatography on silica gel $(\mathrm{PE}: \mathrm{EA}=20: 1)$ to give 10 as a white solid $\left(852.2 \mathrm{mg}, 72 \%\right.$ yield). ${ }^{1} \mathrm{H}$ NMR $\left(400 \mathrm{MHz}, \mathrm{CDCl}_{3}\right) \delta 8.12(\mathrm{~d}, J=$ $8.0 \mathrm{~Hz}, 2 \mathrm{H}), 7.75(\mathrm{~d}, J=8.0 \mathrm{~Hz}, 2 \mathrm{H}), 7.53(\mathrm{dd}, J=7.6,7.2 \mathrm{~Hz}, 1 \mathrm{H}), 7.35$ (dd, $J=8.0$, $6.8 \mathrm{~Hz}, 1 \mathrm{H}), 7.29-7.26(\mathrm{~m}, 1 \mathrm{H}), 7.19(\mathrm{~d}, J=7.6 \mathrm{~Hz}, 1 \mathrm{H}), 6.24(\mathrm{t}, J=6.8 \mathrm{~Hz}, 1 \mathrm{H})$, $5.17(\mathrm{~d}, J=6.8 \mathrm{~Hz}, 2 \mathrm{H}), 3.95(\mathrm{~s}, 3 \mathrm{H}), 1.23(\mathrm{~s}, 9 \mathrm{H}) .{ }^{13} \mathrm{C} \mathrm{NMR}\left(100 \mathrm{MHz}, \mathrm{CDCl}_{3}\right) \delta$ 210.5, 171.23, 166.1, 152.5, 140.6, 135.5, 132.3, 132.0, 129.4, 128.9, 128.7, 128.2, 127.8, 127.6, 88.9, 84.0, 78.9, 52.4, 27.4. HRMS (ESI): Calcd for $\left[\mathrm{C}_{23} \mathrm{H}_{23} \mathrm{NO}_{5} \mathrm{Na}\right]^{+}$ $[\mathrm{M}+\mathrm{Na}]^{+}$416.1468, Found 416.1465 .<smiles>CCN(C(=O)c1ccc([N+](=O)[O-])cc1)c1ccccc1</smiles>

$N$-Boc- $N$-(4-(nitro)benzoyl)-2-allenylaniline (1p). According to the general procedure, 1p was synthesized with $N$-Boc-2-iodoaniline $(3.0 \mathrm{mmol}, 957.3 \mathrm{mg}$ ). Purified by flash column chromatography on silica gel (PE : EA = $20: 1$ ) to give 1p as a yellow solid $\left(531.4 \mathrm{mg}, 47 \%\right.$ yield). ${ }^{1} \mathrm{H} \mathrm{NMR}\left(400 \mathrm{MHz}, \mathrm{CDCl}_{3}\right) \delta 8.30(\mathrm{~d}, J=$ $8.8 \mathrm{~Hz}, 2 \mathrm{H}), 7.81(\mathrm{~d}, J=8.4 \mathrm{~Hz}, 2 \mathrm{H}), 7.52(\mathrm{~d}, J=7.6 \mathrm{~Hz}, 1 \mathrm{H}), 7.36(\mathrm{dd}, J=7.6,7.2$ $\mathrm{Hz}, 1 \mathrm{H}), 7.29(\mathrm{~d}, J=7.6 \mathrm{~Hz}, 1 \mathrm{H}), 7.17(\mathrm{~d}, J=7.6 \mathrm{~Hz}, 1 \mathrm{H}), 6.21(\mathrm{t}, J=6.8 \mathrm{~Hz}, 1 \mathrm{H})$, $5.18(\mathrm{~d}, J=6.8 \mathrm{~Hz}, 2 \mathrm{H}), 1.27(\mathrm{~s}, 9 \mathrm{H}) .{ }^{13} \mathrm{C} \mathrm{NMR}\left(100 \mathrm{MHz}, \mathrm{CDCl}_{3}\right) \delta 210.7,170.0$, 152.3, 149.1, 142.4, 135.3, 132.1, 129.0, 128.9, 128.5, 128.4, 127.9, 123.4, 89.0, 84.4, 78.8, 27.5. HRMS (ESI): Calcd for $\left[\mathrm{C}_{21} \mathrm{H}_{20} \mathrm{~N}_{2} \mathrm{O}_{5} \mathrm{Na}\right]^{+}[\mathrm{M}+\mathrm{Na}]^{+} 403.1264$, Found 403.1273 .<smiles>CC=Cc1ccccc1N(C)C(=O)c1ccc(C(F)(F)F)cc1</smiles>

$N$-Boc- $N$-(4-(trifluoromethyl)benzoyl)-2-allenylaniline (1q). According to the general procedure, 1q was synthesized with $N$-Boc-2-iodoaniline (3.0 mmol, 957.3 $\mathrm{mg})$. Purified by flash column chromatography on silica gel $(\mathrm{PE}: \mathrm{EA}=50: 1)$ to give $1 q$ as a yellow oil $\left(496.9 \mathrm{mg}, 39 \%\right.$ yield). ${ }^{1} \mathrm{H}$ NMR $\left(400 \mathrm{MHz}, \mathrm{CDCl}_{3}\right) \delta 7.79(\mathrm{~d}, J=$ $8.0 \mathrm{~Hz}, 2 \mathrm{H}), 7.70$ (d, $J=8.0 \mathrm{~Hz}, 2 \mathrm{H}), 7.52$ (d, $J=8.0 \mathrm{~Hz}, 1 \mathrm{H}), 7.34$ (dd, $J=7.6,7.2$ $\mathrm{Hz}, 1 \mathrm{H}), 7.26(\mathrm{dd}, J=8.0,8.0 \mathrm{~Hz}, 1 \mathrm{H}), 7.17(\mathrm{~d}, J=7.8 \mathrm{~Hz}, 1 \mathrm{H}), 6.23$ (t, $J=6.8 \mathrm{~Hz}$, $1 \mathrm{H}), 5.16(\mathrm{~d}, J=6.8 \mathrm{~Hz}, 2 \mathrm{H}), 1.25(\mathrm{~s}, 9 \mathrm{H}) .{ }^{13} \mathrm{C} \mathrm{NMR}\left(100 \mathrm{MHz}, \mathrm{CDCl}_{3}\right) \delta 210.6$, $170.8,152.5,140.0,135.6,132.8$ (q, $J=32.8 \mathrm{~Hz}), 132.1,129.0,128.8,128.3,128.0$, 127.8, $125.2(\mathrm{q}, J=3.2 \mathrm{~Hz}), 123.6(\mathrm{q}, J=271 \mathrm{~Hz}), 89.0,84.1,78.8,27.4$. HRMS (ESI): Calcd for $\left[\mathrm{C}_{22} \mathrm{H}_{20} \mathrm{~F}_{3} \mathrm{NO}_{3} \mathrm{Na}\right]^{+}[\mathrm{M}+\mathrm{Na}]^{+}$426.1287, Found 426.1267. 


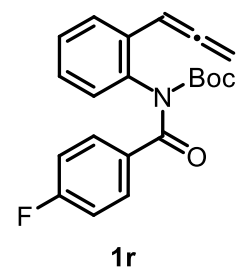

$N$-Boc- $N$-(4-(fluoro)benzoyl)-2-allenylaniline (1r). According to the general procedure, 1r was synthesized with $N$-Boc-2-iodoaniline $(3.0 \mathrm{mmol}, 957.3 \mathrm{mg}$ ). Purified by flash column chromatography on silica gel (PE : EA = $30: 1)$ to give 1r as a white solid (900.5 mg, 85\% yield). ${ }^{1} \mathrm{H}$ NMR $\left(400 \mathrm{MHz}, \mathrm{CDCl}_{3}\right) \delta 7.79-7.70(\mathrm{~m}$, $2 \mathrm{H}), 7.52(\mathrm{~d}, J=7.6 \mathrm{~Hz}, 1 \mathrm{H}), 7.32$ (ddd, $J=7.6,8.0,1.6 \mathrm{~Hz}, 1 \mathrm{H}), 7.24$ (ddd, $J=7.6$, 7.6, $1.2 \mathrm{~Hz}, 1 \mathrm{H}), 7.16-7.07(\mathrm{~m}, 3 \mathrm{H}), 6.25(\mathrm{t}, J=6.8 \mathrm{~Hz}, 1 \mathrm{H}), 5.15(\mathrm{~d}, J=6.8 \mathrm{~Hz}$, 2H), $1.28(\mathrm{~s}, 9 \mathrm{H}) .{ }^{13} \mathrm{C} \mathrm{NMR}\left(100 \mathrm{MHz}, \mathrm{CDCl}_{3}\right) \delta 210.6,170.8,164.6(\mathrm{~d}, J=251,4)$, 152.9, 136.0, 132.5 (d, $J=2.5$ ), 132.1, 130.5 (d, $J=8.9$ ), 129.0, 128.6, 128.1, 127.7, $115.3(\mathrm{~d}, J=22.0), 89.0,83.6,78.8,27.5$. HRMS (ESI): Calcd for $\left[\mathrm{C}_{21} \mathrm{H}_{20} \mathrm{FNO}_{3} \mathrm{Na}\right]^{+}$ $[\mathrm{M}+\mathrm{Na}]^{+}$376.1319, Found 376.1318 .<smiles>CC=Cc1ccccc1NC(=O)c1ccc(Br)cc1</smiles>

$N$-Boc- $N$-(4-(bromo)benzoyl)-2-allenylaniline (1s). According to the general procedure, 1s was synthesized with $N$-Boc-2-iodoaniline $(3.0 \mathrm{mmol}, 957.3 \mathrm{mg})$. Purified by flash column chromatography on silica gel $(\mathrm{PE}: \mathrm{EA}=30: 1)$ to give $1 \mathrm{~s}$ as a yellow solid (548.3 mg, $44 \%$ yield). ${ }^{1} \mathrm{H}$ NMR $\left(400 \mathrm{MHz}, \mathrm{CDCl}_{3}\right) \delta 7.60-7.54(\mathrm{~m}$, $4 \mathrm{H}), 7.50(\mathrm{~d}, J=7.6 \mathrm{~Hz}, 1 \mathrm{H}), 7.31(\mathrm{dd}, J=7.6,7.6 \mathrm{~Hz}, 1 \mathrm{H}), 7.23(\mathrm{dd}, J=8.0,8.0 \mathrm{~Hz}$, $1 \mathrm{H}), 7.14(\mathrm{~d}, J=8.0 \mathrm{~Hz}, 1 \mathrm{H}), 6.23(\mathrm{t}, J=6.8 \mathrm{~Hz}, 1 \mathrm{H}), 5.14(\mathrm{~d}, J=6.8 \mathrm{~Hz}, 2 \mathrm{H}), 1.26$ (s, 9H). ${ }^{13} \mathrm{C}$ NMR $\left(100 \mathrm{MHz}, \mathrm{CDCl}_{3}\right) \delta$ 210.52, 170.95, 152.66, 135.78, 135.20, 132.00, 131.33, 129.50, 128.88, 128.58, 128.09, 127.67, 126.04, 88.96, 83.70, 78.78, 27.40. HRMS (ESI): Calcd for $\left[\mathrm{C}_{21} \mathrm{H}_{20} \mathrm{BrNO}_{3} \mathrm{Na}\right]^{+}[\mathrm{M}+\mathrm{Na}]^{+}$436.0519, Found 436.0515 .

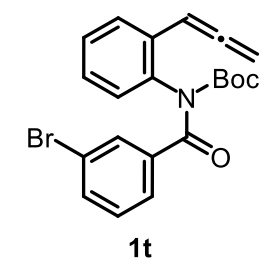

$N$-Boc- $N$-(3-(bromo)benzoyl)-2-allenylaniline (1t). According to the general procedure, 1t was synthesized with $N$-Boc-2-iodoaniline $(3.0 \mathrm{mmol}, 957.3 \mathrm{mg}$ ). Purified by flash column chromatography on silica gel (PE : EA $=30: 1)$ to give $\mathbf{1 t}$ as a yellow solid $\left(910.2 \mathrm{mg}, 73 \%\right.$ yield). ${ }^{1} \mathrm{H} \mathrm{NMR}\left(400 \mathrm{MHz}, \mathrm{CDCl}_{3}\right) \delta 7.83-7.78(\mathrm{~m}$, $1 \mathrm{H}), 7.65-7.62(\mathrm{~m}, 2 \mathrm{H}), 7.53(\mathrm{~d}, J=7.6 \mathrm{~Hz}, 1 \mathrm{H}), 7.37-7.32(\mathrm{~m}, 2 \mathrm{H}), 7.30-7.28$ (m, 1H), $7.19-7.17(\mathrm{~m}, 1 \mathrm{H}), 6.24-6.20(\mathrm{~m}, 1 \mathrm{H}), 5.17(\mathrm{~d}, J=6.8 \mathrm{~Hz}, 2 \mathrm{H}), 1.26(\mathrm{~s}$, $9 \mathrm{H}) .{ }^{13} \mathrm{C} \mathrm{NMR}\left(100 \mathrm{MHz}, \mathrm{CDCl}_{3}\right) \delta 210.7,170.4,152.6,138.5,135.8,134.3,132.2$, 
130.9, 129.8, 129.0, 128.8, 128.3, 127.8, 126.4, 122.1, 89.1, 84.0, 78.8, 27.5. HRMS (ESI): Calcd for $\left[\mathrm{C}_{21} \mathrm{H}_{20} \mathrm{BrNO}_{3} \mathrm{Na}\right]^{+}[\mathrm{M}+\mathrm{Na}]^{+} 436.0519$, Found 436.0529.<smiles>C=Cc1ccccc1N(C)C(=O)c1ccccc1Cl</smiles>

$N$-Boc- $N$-(2-(chloro)benzoyl)-2-allenylaniline (1u). According to the general procedure, 1u was synthesized with $N$-Boc-2-iodoaniline $(3.0 \mathrm{mmol}, 957.3 \mathrm{mg})$. Purified by flash column chromatography on silica gel (PE : EA = $30: 1)$ to give 1u as a yellow solid $\left(814.7 \mathrm{mg}, 73 \%\right.$ yield). ${ }^{1} \mathrm{H}$ NMR $\left(400 \mathrm{MHz}, \mathrm{CDCl}_{3}\right) \delta 7.52(\mathrm{~d}, J=$ $7.6 \mathrm{~Hz}, 1 \mathrm{H}), 7.48-7.46(\mathrm{~m}, 1 \mathrm{H}), 7.40(\mathrm{~d}, J=7.2 \mathrm{~Hz}, 1 \mathrm{H}), 7.38-7.33(\mathrm{~m}, 3 \mathrm{H}), 7.32$ $-7.28(\mathrm{~m}, 2 \mathrm{H}), 6.26(\mathrm{t}, J=6.8 \mathrm{~Hz}, 1 \mathrm{H}), 5.16(\mathrm{~d}, J=6.8 \mathrm{~Hz}, 2 \mathrm{H}), 1.21(\mathrm{~s}, 9 \mathrm{H}) .{ }^{13} \mathrm{C}$ NMR $\left(100 \mathrm{MHz}, \mathrm{CDCl}_{3}\right) \delta 210.6,169.0,151.5,137.5,135.4,131.9,130.6,130.0$, 129.3, 128.9, 128.7, 128.3, 128.1, 127.8, 126.9, 89.2, 83.8, 78.6, 27.3. HRMS (ESI): Calcd for $\left[\mathrm{C}_{21} \mathrm{H}_{21} \mathrm{ClNO}_{3}\right]^{+}[\mathrm{M}+\mathrm{H}]^{+}$370.1204, Found 370.1211 .

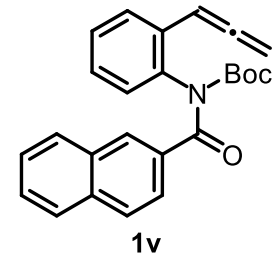

$N$-Boc- $N$-(2-naphthoyl)-2-allenylaniline (1v). According to the general procedure, 1v was synthesized with $N$-Boc-2-iodoaniline $(3.2 \mathrm{mmol}, 1.0211 \mathrm{~g})$. Purified by flash column chromatography on silica gel $(\mathrm{PE}: \mathrm{EA}=30: 1)$ to give $\mathbf{1 v}$ as a yellow solid (742.2 mg, 60\% yield). ${ }^{1} \mathrm{H}$ NMR $\left(400 \mathrm{MHz}, \mathrm{CDCl}_{3}\right) \delta 8.26(\mathrm{~s}, 1 \mathrm{H}), 7.96-7.83(\mathrm{~m}$, $3 \mathrm{H}), 7.77(\mathrm{~d}, J=8.2 \mathrm{~Hz}, 1 \mathrm{H}), 7.55-7.52(\mathrm{~m}, 3 \mathrm{H}), 7.33-7.32(\mathrm{~m}, 1 \mathrm{H}), 7.29-7.24$ $(\mathrm{m}, 2 \mathrm{H}), 6.34(\mathrm{t}, J=6.4 \mathrm{~Hz}, 1 \mathrm{H}), 5.17(\mathrm{~d}, J=6.4 \mathrm{~Hz}, 2 \mathrm{H}), 1.18(\mathrm{~s}, 9 \mathrm{H}) .{ }^{13} \mathrm{C}$ NMR $\left(100 \mathrm{MHz}, \mathrm{CDCl}_{3}\right) \delta 210.7,172.0,153.1,136.2,134.7,133.7,132.4,132.3,129.1$, 128.9, 128.8, 128.6, 128.2, 127.9, 127.8, 127.8, 127.7, 126.8, 124.6, 89.2, 83.5, 78.8, 27.4. HRMS (ESI): Calcd for $\left[\mathrm{C}_{25} \mathrm{H}_{24} \mathrm{NO}_{3}\right]^{+}[\mathrm{M}+\mathrm{H}]^{+} 386.1751$, Found 386.1761 .

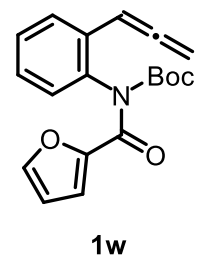

$N$-Boc- $N$-(furan-2-carbonyl)-2-allenylaniline (1w). According to the general procedure, $1 \mathbf{w}$ was synthesized with $N$-Boc-2-iodoaniline $(3.2 \mathrm{mmol}, 1.0211 \mathrm{~g})$. Purified by flash column chromatography on silica gel (PE : EA $=20: 1$ ) to give $\mathbf{1 w}$ as a yellow solid $\left(536.7 \mathrm{mg}, 52 \%\right.$ yield). ${ }^{1} \mathrm{H}$ NMR (400 $\left.\mathrm{MHz}, \mathrm{CDCl}_{3}\right) \delta 7.54-7.52$ $(\mathrm{m}, 2 \mathrm{H}), 7.33(\mathrm{dd}, J=7.2,6.4 \mathrm{~Hz}, 1 \mathrm{H}), 7.26-7.22(\mathrm{~m}, 2 \mathrm{H}), 7.19(\mathrm{~d}, J=6.8 \mathrm{~Hz}, 1 \mathrm{H})$, 6.97 (brs, 1H), 6.50 (brs, 1H), $6.31(\mathrm{t}, J=5.6 \mathrm{~Hz}, 1 \mathrm{H}), 5.14$ (d, $J=5.6 \mathrm{~Hz}, 2 \mathrm{H}), 1.37$ 
(s, 9H). $\left.{ }^{13} \mathrm{C} \mathrm{NMR} \mathrm{(100} \mathrm{MHz,} \mathrm{CDCl}_{3}\right) \delta 210.6,160.7,152.4,148.0,144.9,135.4$, 132.3, 129.3, 128.7, 127.9, 127.6, 117.8, 112.2, 88.9, 83.3, 78.8, 27.5. HRMS (ESI): Calcd for $\left[\mathrm{C}_{19} \mathrm{H}_{19} \mathrm{NO}_{4} \mathrm{Na}\right]^{+}[\mathrm{M}+\mathrm{Na}]^{+} 348.1206$, Found 348.1200.

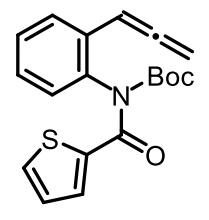

$1 \mathrm{x}$

$\boldsymbol{N}$-Boc- $\boldsymbol{N}$-(thiophene-2-carbonyl)-2-allenylaniline (1x). According to the general procedure, 1x was synthesized with $N$-Boc-2-iodoaniline $(3.0 \mathrm{mmol}, 957.3 \mathrm{mg})$. Purified by flash column chromatography on silica gel (PE : EA $=20: 1$ ) to give $\mathbf{1 x}$ as a yellow solid (773.0 mg, 75\% yield). ${ }^{1} \mathrm{H} \mathrm{NMR}\left(400 \mathrm{MHz}, \mathrm{CDCl}_{3}\right) \delta 7.52-7.50$ $(\mathrm{m}, 2 \mathrm{H}), 7.44(\mathrm{dd}, J=3.6,0.8 \mathrm{~Hz}, 1 \mathrm{H}), \delta 7.35-7.30(\mathrm{~m}, 1 \mathrm{H}), 7.25-7.15(\mathrm{~m}, 1 \mathrm{H})$, $7.00-6.98(\mathrm{~m}, 2 \mathrm{H}), 6.31(\mathrm{t}, J=6.8 \mathrm{~Hz}, 1 \mathrm{H}), 5.14(\mathrm{~d}, J=6.8 \mathrm{~Hz}, 2 \mathrm{H}), 1.39(\mathrm{~s}, 9 \mathrm{H})$. ${ }^{13} \mathrm{C}$ NMR $\left(100 \mathrm{MHz}, \mathrm{CDCl}_{3}\right) \delta 210.7,164.2,152.8,138.5,136.2,133.0,132.6,132.4$, 129.4, 128.8, 128.1, 127.7, 127.1, 89.1, 83.5, 78.8, 27.7. HRMS (ESI): Calcd for $\left[\mathrm{C}_{19} \mathrm{H}_{20} \mathrm{NO}_{3} \mathrm{~S}\right]^{+}[\mathrm{M}+\mathrm{H}]^{+}$342.1158, Found 342.1153.<smiles>C=Cc1ccc(N(C(=O)c2ccccc2)C(=O)c2ccccc2)cc1</smiles>

13

$N$-Boc- $N$-benzoyl-4-allenylaniline (13) To a solution of $N$-Boc-4-iodoaniline (3.0 mmol, $957.3 \mathrm{mg})$ in dry THF $(9 \mathrm{~mL})$ was added sodium hydride $(4.5 \mathrm{mmol}, 60 \%$ in mineral iol, $180 \mathrm{mg}$ ) at $0{ }^{\circ} \mathrm{C}$ under $\mathrm{N}_{2}$ atomosphere. After being stirred at the same temperature for $10 \mathrm{~min}$, acyl chloride $\left(3.6 \mathrm{mmol}, 506.0 \mathrm{mg}\right.$ ) was added at $-78{ }^{\circ} \mathrm{C}$. After being stirred at the same temperature for $1 \mathrm{~h}$, the reaction mixture was quenched with $1 \mathrm{M}$ aqueous $\mathrm{HCl}$ at $0{ }^{\circ} \mathrm{C}$. The organic layer was separated, and the aqueous layer was extracted with ethyl acetate. The combined organic layers were washed with saturated aqueous $\mathrm{NaHCO}_{3}$ and brine, dried over anhydrous sodium sulfate and evaporated to get the residues without further purification. Then, to a solution of the crude material and allenyltributyltin $(9.0 \mathrm{mmol}, 1.4805 \mathrm{~g})$ in anhydrous DMF $(0.125$ M) was degassed and purged with nitrogen. $\mathrm{Pd}\left(\mathrm{PPh}_{3}\right)_{4}(5 \mathrm{~mol} \%, 173.3 \mathrm{mg}), \mathrm{LiCl}(9.0$ $\mathrm{mmol}, 381.6 \mathrm{mg}$ ) were added to the reaction mixture at room temperature (rt) under $\mathrm{N}_{2}$ atmosphere. The reaction mixture was stirred at $80{ }^{\circ} \mathrm{C}$ for $2 \mathrm{~h}$, added water and extracted with diethyl ether. The combined extractions were washed with brine, dried over anhydrous sodium sulfate and evaporated to get the residues, which was purified by flash silica gel chromatography on silica gel $(\mathrm{PE}: \mathrm{EA}=40: 1)$ to give $\mathbf{1 3}$ as a white solid (654.0 mg, 65\% yield). ${ }^{1} \mathrm{H}$ NMR (400 MHz, $\left.\mathrm{CDCl}_{3}\right) \delta 7.72(\mathrm{~d}, J=7.2 \mathrm{~Hz}$, $2 \mathrm{H}), 7.51(\mathrm{dd}, J=7.2 \mathrm{~Hz}, 1 \mathrm{H}), 7.43(\mathrm{dd}, J=7.6 \mathrm{~Hz}, 2 \mathrm{H}), 7.33(\mathrm{~d}, J=8.4 \mathrm{~Hz}, 2 \mathrm{H})$, $7.19(\mathrm{~d}, J=8.4 \mathrm{~Hz}, 2 \mathrm{H}), 6.17(\mathrm{t}, J=6.8 \mathrm{~Hz}, 1 \mathrm{H}), 5.16(\mathrm{~d}, J=6.8 \mathrm{~Hz}, 2 \mathrm{H}), 1.23(\mathrm{~s}$, 9H). ${ }^{13} \mathrm{C} \mathrm{NMR}\left(100 \mathrm{MHz}, \mathrm{CDCl}_{3}\right) \delta 210.1,172.7,153.2,137.6,136.9,133.6,131.7$, 
128.2, 128.1, 128.0, 127.4, 93.4, 83.5, 78.9, 27.46. HRMS (ESI): Calcd for $\left[\mathrm{C}_{21} \mathrm{H}_{22} \mathrm{NO}_{3}\right]^{+}[\mathrm{M}+\mathrm{H}]^{+}$336.1594, Found 336.1599.

\section{DFT Studies}

\section{Computational methods}

DFT calculations were performed with Gaussian $09 .{ }^{6}$ The hybrid-meta GGA functional M06-2X $\mathrm{X}^{7}$ with 6-31+G(d,p) was employed for optimizing the geometries of minima and transition states. The $\mathrm{SMD}^{8}$ implicit solvation model was used to account for solvation effects of tetrahydrofuran (THF). Pruned integration grids with 99 radial shells and 590 angular points per shell were used. Unscaled harmonic frequency calculations at the same level were performed to validate each structure as either a minimum or a transition state and to evaluate its zero-point energy and thermal corrections at $298 \mathrm{~K}$. Quasiharmonic corrections were applied during the entropy calculations by setting all positive frequencies that are less than $100 \mathrm{~cm}^{-1}$ to 100 $\mathrm{cm}^{-1} .{ }^{9}$ On the basis of the optimized structures, single-point energies were computed at the SMD(THF)-M06-2X/6-311+G(d,p) level. All discussed energy differences were based on Gibbs energies in THF at $298 \mathrm{~K}$. Standard states for solutes in THF solution are the hypothetical states at $1 \mathrm{~mol} / \mathrm{L}$.

For [1,3]-proton transfer assisted by water, the activation energy is $19.3 \mathrm{kcal} / \mathrm{mol}$, which is higher than intramolecular [1,4]-proton transfer to NBoc anion pathway (11.5 kcal/mol, TS4) and [1,4]-proton transfer pathway assisted by water (11.3 $\mathrm{kcal} / \mathrm{mol}$, TS8). From INT3 to INT5, both a direct [1,3]-proton transfer and a $[1,3]$-proton transfer assisted by water are quite difficult (Figure S4).

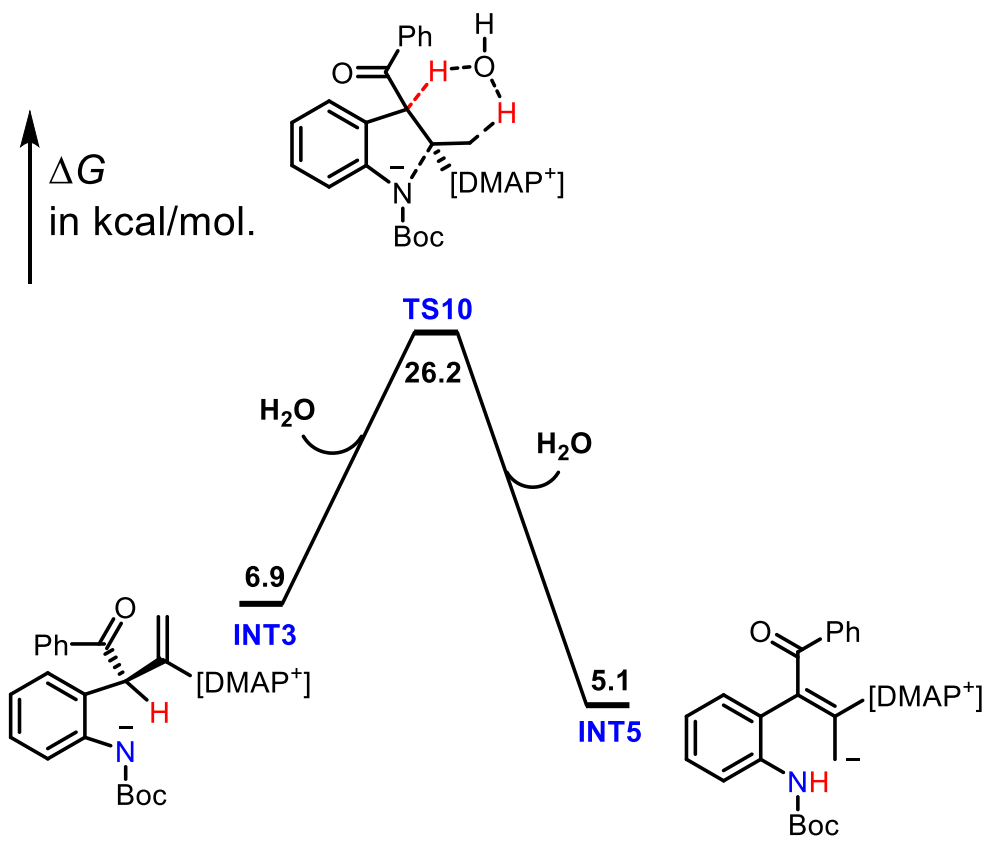

Figure S4 [1,3]-Proton transfer assisted by water. Computed at the SMD(THF)-M06-2X/6-311+G(d,p)//SMD(THF)-M06-2X/6-31+G(d,p) level. 
For INT3 and INT4, the protonations are thermodynamically disfavored. As a result, the proton transfer processes can't be stepwise assisted by a trace amount of water in THF.<smiles>C=C(OCc1ccccc1)C(C(=O)Nc1ccccc1)(c1ccccc1)c1ccccc1</smiles>

INT3<smiles>C=C(Nc1ccccc1)C(C(=O)O)(C(=O)Nc1ccccc1)c1ccccc1</smiles>

INT3

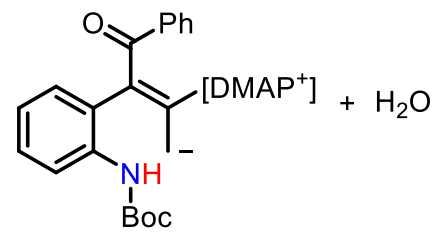

INT4

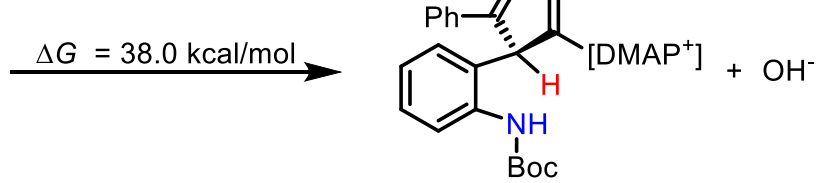

INT3NH<smiles>C#[13C]C</smiles><smiles>O=C([O-])N1c2ccccc2[C@]1(C(=O)[18OH])C(=O)c1ccccc1</smiles>

INT3CH

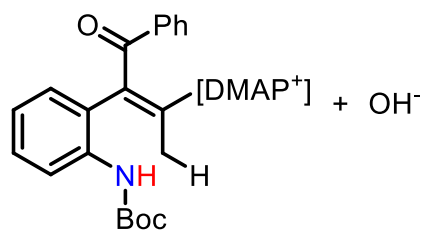

INT4CH

Figure S5 Direct protonations of INT3 and INT4 by water. Computed at the SMD(THF)-M06-2X/6-311+G(d,p)//SMD(THF)-M06-2X/6-31+G(d,p) level.

\section{Computed Energies for the Stationary Points}

Table S2. Thermal corrections to Gibbs energies (TCGs), single-point energies (SPEs) and Gibbs energies.

\begin{tabular}{|c|c|c|c|}
\hline & TCGs & SPEs & Gibbs Energies \\
\hline DMAP & 0.130507 & -382.2009522 & -382.0704452 \\
\hline 1a & 0.325192 & -1093.154545 & -1092.829353 \\
\hline 2a & 0.33007 & -1093.215651 & -1092.885581 \\
\hline DMAP & 0.130507 & -382.2009522 & -382.0704452 \\
\hline INT1 & 0.484128 & -1475.356339 & -1474.872211 \\
\hline INT2 & 0.487143 & -1475.370419 & -1474.883276 \\
\hline INT2p & 0.487296 & -1475.356876 & -1474.86958 \\
\hline INT3 & 0.485928 & -1475.371675 & -1474.885747 \\
\hline INT4 & 0.485848 & -1475.383244 & -1474.897396 \\
\hline INT5 & 0.484584 & -1475.373198 & -1474.888614 \\
\hline INT6 & 0.487865 & -1475.404116 & -1474.916251 \\
\hline INT7 & 0.26319 & -729.8538213 & -729.5906313 \\
\hline INT8 & 0.18473 & -498.8202191 & -498.6354891 \\
\hline INT9 & 0.225583 & -726.716443 & -726.49086 \\
\hline INT3NH & 0.499234 & -1475.854563 & -1475.355329 \\
\hline
\end{tabular}




\begin{tabular}{|c|c|c|c|} 
INT3CH & 0.502465 & -1475.854983 & -1475.352518 \\
\hline INT4CH & 0.499485 & -1475.858081 & -1475.358596 \\
\hline H2O & 0.003691 & -76.42793912 & -76.42424812 \\
\hline OH- & -0.007476 & -75.88655743 & -75.89403343 \\
\hline $\mathbf{9}$ & 0.106196 & -347.6566987 & -347.5505027 \\
\hline $\mathbf{1 5}$ & 0.031385 & -116.6313454 & -116.5999604 \\
\hline $\mathbf{1 6}$ & 0.06871 & -344.4984305 & -344.4297205 \\
\hline TS1 & 0.480242 & -1475.331947 & -1474.851705 \\
\hline TS2 & 0.484262 & -1475.346403 & -1474.862141 \\
\hline TS2p & 0.484868 & -1475.338961 & -1474.854093 \\
\hline TS3p & 0.486494 & -1475.351214 & -1474.86472 \\
\hline TS4 & 0.480876 & -1475.348412 & -1474.867536 \\
\hline TS5 & 0.480759 & -1475.349087 & -1474.868328 \\
\hline TS6 & 0.484597 & -1475.350997 & -1474.8664 \\
\hline TS7 & 0.486008 & -1475.392964 & -1474.906956 \\
\hline TS8 & 0.50438 & -1551.793433 & -1551.289053 \\
\hline TS9 & 0.502069 & -1551.780224 & -1551.278155 \\
\hline TS10 & 0.504952 & -1551.779012 & -1551.27406 \\
\hline TS11 & 0.260069 & -729.8331294 & -729.5730604 \\
\hline TS12 & 0.182419 & -498.8007631 & -498.6183441 \\
\hline TS13 & 0.222066 & -726.6839372 & -726.4618712 \\
\hline TS-1,3 & 0.481567 & -1475.300561 & -1474.818994 \\
\hline TS-L & 0.480815 & -1475.342155 & -1474.86134 \\
\hline
\end{tabular}

\section{Cartesian coordinates for the stationary points}

\begin{tabular}{|c|c|c|c|}
\hline \multicolumn{4}{|c|}{ DMAP } \\
\hline$C$ & 0.564421 & 1.200065 & -0.008470 \\
\hline$C$ & 1.948933 & 1.134147 & -0.010763 \\
\hline $\mathrm{N}$ & 2.664204 & 0.000044 & -0.001931 \\
\hline$C$ & 1.948948 & -1.134056 & 0.009062 \\
\hline$C$ & 0.564440 & -1.199939 & 0.011421 \\
\hline C & -0.186863 & 0.000079 & 0.003400 \\
\hline $\mathrm{N}$ & -1.546063 & -0.000062 & 0.006841 \\
\hline C & -2.270620 & -1.258598 & -0.020207 \\
\hline C & -2.271159 & 1.258393 & 0.014802 \\
\hline $\mathrm{H}$ & 0.082842 & 2.169917 & -0.019311 \\
\hline $\mathrm{H}$ & 2.520696 & 2.059863 & -0.021335 \\
\hline $\mathrm{H}$ & 2.520735 & -2.059783 & 0.016975 \\
\hline $\mathrm{H}$ & 0.082819 & -2.169774 & 0.022671 \\
\hline $\mathrm{H}$ & -2.062488 & -1.860346 & 0.872994 \\
\hline H & -3.339151 & -1.049893 & -0.053148 \\
\hline $\mathrm{H}$ & -2.008598 & -1.849932 & -0.905851 \\
\hline
\end{tabular}

\begin{tabular}{cccc} 
H & -2.004189 & 1.864804 & 0.888371 \\
H & -2.068942 & 1.844956 & -0.890092 \\
H & -3.339315 & 1.049767 & 0.058886 \\
$1 \mathrm{a}$ & & & \\
$\mathrm{C}$ & 4.937423 & -0.649297 & -0.667959 \\
$\mathrm{C}$ & 4.113742 & -1.434143 & -1.474178 \\
$\mathrm{C}$ & 2.730963 & -1.348619 & -1.329806 \\
$\mathrm{C}$ & 2.179884 & -0.503195 & -0.373926 \\
$\mathrm{C}$ & 2.991493 & 0.272222 & 0.467926 \\
$\mathrm{C}$ & 4.378756 & 0.197667 & 0.285322 \\
$\mathrm{~N}$ & 0.746541 & -0.411788 & -0.285379 \\
$\mathrm{C}$ & 0.069228 & -1.425443 & 0.413243 \\
$\mathrm{O}$ & 0.683840 & -2.187284 & 1.134579 \\
$\mathrm{C}$ & 2.463777 & 1.171073 & 1.517916 \\
$\mathrm{C}$ & 1.343709 & 1.009606 & 2.188585 \\
$\mathrm{C}$ & 0.250066 & 0.839404 & 2.881972 \\
\hline & -0.956752 & 1.052299 & -0.077696
\end{tabular}




\begin{tabular}{|c|c|c|c|c|c|c|c|}
\hline C & -1.802372 & 2.201839 & -0.420097 & C & -0.410960 & -0.750912 & -0.176794 \\
\hline C & -3.046075 & 1.945983 & 0.420828 & C & -0.933961 & -2.136848 & 0.008521 \\
\hline C & -2.146273 & 2.187924 & -1.904575 & 0 & -3.184378 & -0.628787 & -0.106350 \\
\hline C & -1.096660 & 3.481647 & 0.008759 & c & -4.621533 & -0.821618 & 0.159668 \\
\hline C & 0.188615 & 0.818188 & -0.695693 & C & -4.845104 & -2.259277 & -0.288651 \\
\hline 0 & 0.753268 & 1.545170 & -1.481521 & C & -5.434347 & 0.146154 & -0.690266 \\
\hline C & -1.394117 & -1.606294 & 0.164046 & C & -4.895626 & -0.669879 & 1.650410 \\
\hline C & -2.211713 & -1.935080 & 1.246063 & $\mathrm{C}$ & -2.573282 & 0.496412 & 0.216927 \\
\hline C & -3.572128 & -2.159343 & 1.042931 & 0 & -3.085518 & 1.509318 & 0.635094 \\
\hline C & -4.107079 & -2.084355 & -0.243636 & C & 3.347613 & -0.998415 & -0.057146 \\
\hline C & -3.282266 & -1.778254 & -1.328197 & $C$ & 3.480846 & -0.256269 & 1.121627 \\
\hline C & -1.927494 & -1.528689 & -1.125173 & C & 4.744832 & -0.028410 & 1.662281 \\
\hline $\mathrm{H}$ & 6.016181 & -0.695148 & -0.781165 & C & 5.879020 & -0.523526 & 1.018017 \\
\hline $\mathrm{H}$ & 4.541589 & -2.096263 & -2.220063 & C & 5.749853 & -1.261629 & -0.160585 \\
\hline $\mathrm{H}$ & 2.064850 & -1.929141 & -1.962074 & C & 4.486779 & -1.508105 & -0.690560 \\
\hline $\mathrm{H}$ & 5.021975 & 0.806671 & 0.914862 & $\mathrm{H}$ & 2.439852 & 4.092707 & -0.809452 \\
\hline $\mathrm{H}$ & 3.101931 & 2.012699 & 1.786794 & $\mathrm{H}$ & 0.134933 & 4.863315 & -0.338481 \\
\hline $\mathrm{H}$ & -0.696748 & 1.262782 & 2.552944 & $\mathrm{H}$ & -1.689560 & 3.240307 & 0.072607 \\
\hline $\mathrm{H}$ & 0.258482 & 0.249672 & 3.796362 & $\mathrm{H}$ & 2.973618 & 1.676844 & -0.874845 \\
\hline $\mathrm{H}$ & -2.794146 & 1.922106 & 1.485797 & $\mathrm{H}$ & -1.558957 & -2.443553 & -0.834202 \\
\hline $\mathrm{H}$ & -3.775667 & 2.743178 & 0.253380 & $\mathrm{H}$ & -1.538242 & -2.207711 & 0.916018 \\
\hline $\mathrm{H}$ & -3.499470 & 0.987364 & 0.145950 & $\mathrm{H}$ & -0.090416 & -2.822359 & 0.079050 \\
\hline $\mathrm{H}$ & -1.272424 & 2.389580 & -2.525799 & $\mathrm{H}$ & -4.234579 & -2.947932 & 0.303196 \\
\hline $\mathrm{H}$ & -2.895549 & 2.962009 & -2.096219 & $\mathrm{H}$ & -5.897582 & -2.523386 & -0.154528 \\
\hline $\mathrm{H}$ & -2.575994 & 1.220730 & -2.185325 & $\mathrm{H}$ & -4.587459 & -2.377051 & -1.345390 \\
\hline $\mathrm{H}$ & -1.783504 & 4.325763 & -0.107046 & $\mathrm{H}$ & -5.297855 & 1.178982 & -0.366445 \\
\hline $\mathrm{H}$ & -0.803915 & 3.417363 & 1.062142 & $\mathrm{H}$ & -6.493912 & -0.111344 & -0.598765 \\
\hline $\mathrm{H}$ & -0.207663 & 3.667057 & -0.597008 & $\mathrm{H}$ & -5.150444 & 0.057722 & -1.743506 \\
\hline $\mathrm{H}$ & -1.779452 & -2.002363 & 2.240255 & $\mathrm{H}$ & -5.925058 & -0.982136 & 1.849758 \\
\hline $\mathrm{H}$ & -4.212325 & -2.398611 & 1.886467 & $\mathrm{H}$ & -4.225903 & -1.314503 & 2.228909 \\
\hline $\mathrm{H}$ & -5.165326 & -2.268607 & -0.402925 & $\mathrm{H}$ & -4.777372 & 0.362632 & 1.982450 \\
\hline $\mathrm{H}$ & -3.695464 & -1.730554 & -2.331204 & $\mathrm{H}$ & 2.598438 & 0.132962 & 1.621773 \\
\hline H & -1.284868 & -1.282284 & -1.967465 & $\mathrm{H}$ & 4.844166 & 0.537056 & 2.583634 \\
\hline $2 a$ & & & & $\mathrm{H}$ & 6.864189 & -0.336344 & 1.434981 \\
\hline C & 1.658224 & 3.362189 & -0.625151 & $\mathrm{H}$ & 6.632806 & -1.646093 & -0.661855 \\
\hline C & 0.349817 & 3.799384 & -0.360254 & $\mathrm{H}$ & 4.369265 & -2.089759 & -1.599923 \\
\hline C & -0.683520 & 2.898927 & -0.127983 & INT1 & & & \\
\hline C & -0.366740 & 1.537352 & -0.159901 & C & 1.741509 & 4.935759 & -0.693528 \\
\hline C & 0.940968 & 1.079812 & -0.412425 & C & 2.977533 & 4.301130 & -0.839418 \\
\hline C & 1.963127 & 2.008653 & -0.658286 & C & 3.029032 & 2.920827 & -0.641284 \\
\hline $\mathrm{N}$ & -1.187378 & 0.403879 & -0.017118 & C & 1.891500 & 2.208787 & -0.294234 \\
\hline C & 2.002625 & -1.315341 & -0.634448 & C & 0.617604 & 2.821518 & -0.109006 \\
\hline 0 & 1.839739 & -2.348473 & -1.271479 & C & 0.601086 & 4.226463 & -0.336517 \\
\hline C & 0.888532 & -0.369314 & -0.408878 & $\mathrm{~N}$ & 2.036373 & 0.786546 & -0.102956 \\
\hline
\end{tabular}




\begin{tabular}{|c|c|c|c|c|c|c|c|}
\hline C & 2.632787 & 0.331172 & 1.086771 & H & 0.161020 & -3.311857 & 0.589832 \\
\hline 0 & 2.657094 & 1.030860 & 2.080766 & $\mathrm{H}$ & 0.364766 & -4.434268 & -0.774816 \\
\hline C & -0.530304 & 2.040406 & 0.229224 & $\mathrm{H}$ & 1.790631 & -3.682355 & -0.019755 \\
\hline C & -1.830097 & 2.509778 & 0.516299 & $\mathrm{H}$ & 1.435485 & -1.838924 & -3.261435 \\
\hline C & -2.376895 & 3.716564 & 0.854982 & $\mathrm{H}$ & 1.266550 & -3.576815 & -2.941240 \\
\hline C & -3.937066 & -0.234891 & -0.860988 & H & 2.591181 & -2.671460 & -2.190905 \\
\hline C & -3.014365 & 0.768802 & -0.733064 & H & -1.206131 & -2.956980 & -2.213299 \\
\hline $\mathrm{N}$ & -2.827635 & 1.424337 & 0.435862 & H & -1.403096 & -1.911489 & -0.789904 \\
\hline C & -3.563246 & 1.083921 & 1.518410 & H & -0.866840 & -1.216332 & -2.341793 \\
\hline C & -4.498705 & 0.083980 & 1.473063 & $\mathrm{H}$ & 4.106564 & -0.760891 & -0.951597 \\
\hline C & -4.724669 & -0.626751 & 0.259356 & H & 5.380713 & -2.884466 & -0.895241 \\
\hline $\mathrm{N}$ & -5.628219 & -1.614312 & 0.175451 & $\mathrm{H}$ & 5.320788 & -4.318422 & 1.132266 \\
\hline C & -6.425539 & -1.978069 & 1.340926 & $\mathrm{H}$ & 4.012696 & -3.603096 & 3.118765 \\
\hline C & -5.813881 & -2.329738 & -1.081498 & $\mathrm{H}$ & 2.771658 & -1.446404 & 3.074075 \\
\hline 0 & 1.129753 & -1.232170 & -0.495906 & INT2 & & & \\
\hline C & 0.646849 & -2.361293 & -1.293760 & C & 1.973838 & -2.512850 & -2.454240 \\
\hline C & 0.746628 & -3.520575 & -0.310491 & C & 0.999502 & -3.422971 & -2.047265 \\
\hline C & 1.542943 & -2.613492 & -2.501584 & C & -0.158691 & -3.009138 & -1.380553 \\
\hline C & -0.799345 & -2.088022 & -1.685850 & C & -0.324378 & -1.645284 & -1.119073 \\
\hline c & 1.429322 & -0.058310 & -1.045963 & c & 0.653732 & -0.723654 & -1.532380 \\
\hline 0 & 1.178511 & 0.289670 & -2.177823 & C & 1.794503 & -1.148610 & -2.197573 \\
\hline c & 3.347935 & -0.985651 & 1.056723 & $\mathrm{~N}$ & -1.363841 & -0.976635 & -0.461492 \\
\hline C & 4.084339 & -1.385621 & -0.061438 & C & -0.872576 & 0.443997 & -0.008368 \\
\hline C & 4.800214 & -2.580156 & -0.029454 & 0 & -0.353490 & 0.419533 & 1.190090 \\
\hline C & 4.768936 & -3.383408 & 1.111810 & c & 0.199376 & 0.666829 & -1.191356 \\
\hline C & 4.035249 & -2.981170 & 2.229089 & C & 1.240798 & 1.689366 & -0.835650 \\
\hline C & 3.336226 & -1.776350 & 2.207177 & c & 1.088413 & 2.997954 & -1.036022 \\
\hline $\mathrm{H}$ & 1.661480 & 6.007553 & -0.858147 & C & 4.864065 & 1.217832 & -0.237373 \\
\hline H & 3.869980 & 4.857874 & -1.104719 & C & 3.672031 & 1.654709 & -0.740816 \\
\hline H & 3.964113 & 2.376636 & -0.755311 & $\mathrm{~N}$ & 2.482039 & 1.217141 & -0.251867 \\
\hline $\mathrm{H}$ & -0.334905 & 4.763323 & -0.250990 & C & 2.460361 & 0.303106 & 0.756536 \\
\hline $\mathrm{H}$ & -0.408878 & 0.963568 & 0.286227 & C & 3.620107 & -0.176291 & 1.303031 \\
\hline $\mathrm{H}$ & -3.453388 & 3.827625 & 0.922142 & C & 4.886530 & 0.265937 & 0.825540 \\
\hline H & -1.763202 & 4.573388 & 1.095005 & $\mathrm{~N}$ & 6.037010 & -0.188599 & 1.337443 \\
\hline $\mathrm{H}$ & -4.045314 & -0.710342 & -1.826732 & C & 6.019961 & -1.162049 & 2.424711 \\
\hline $\mathrm{H}$ & -2.392025 & 1.098767 & -1.557198 & C & 7.312906 & 0.297566 & 0.823535 \\
\hline H & -3.352816 & 1.645017 & 2.421277 & 0 & -3.143624 & -0.787780 & 0.864124 \\
\hline $\mathrm{H}$ & -5.040375 & -0.151277 & 2.379211 & C & -4.481280 & -1.127120 & 1.320678 \\
\hline H & -7.015222 & -1.124606 & 1.691460 & C & -4.947431 & 0.175631 & 1.961168 \\
\hline $\mathrm{H}$ & -7.107239 & -2.779862 & 1.064017 & C & -4.420560 & -2.247411 & 2.353818 \\
\hline H & -5.786581 & -2.328909 & 2.158322 & C & -5.376704 & -1.480509 & 0.136229 \\
\hline $\mathrm{H}$ & -6.154282 & -1.652324 & -1.871763 & C & -2.429862 & -1.623246 & 0.102076 \\
\hline $\mathrm{H}$ & -4.880715 & -2.807018 & -1.399699 & 0 & -2.708527 & -2.800712 & -0.087613 \\
\hline $\mathrm{H}$ & -6.566598 & -3.102212 & -0.937382 & C & -2.009687 & 1.462413 & -0.206069 \\
\hline
\end{tabular}




\begin{tabular}{|c|c|c|c|c|c|c|c|}
\hline c & -2.872752 & 1.440457 & -1.307603 & $c$ & -1.426879 & 0.336757 & -1.428090 \\
\hline C & -3.855475 & 2.416780 & -1.461315 & 0 & -2.195606 & 0.066052 & -2.433068 \\
\hline C & -3.979166 & 3.443008 & -0.519541 & C & 0.075077 & 0.686161 & -1.952718 \\
\hline C & -3.114704 & 3.476579 & 0.573682 & $\mathrm{C}$ & 0.914011 & 1.728853 & -1.240799 \\
\hline c & -2.138269 & 2.488535 & 0.727693 & C & 0.741918 & 3.043856 & -1.371515 \\
\hline $\mathrm{H}$ & 2.863362 & -2.857899 & -2.972237 & $C$ & 2.871452 & -0.171382 & 1.283459 \\
\hline $\mathrm{H}$ & 1.135059 & -4.481783 & -2.249736 & $C$ & 1.839274 & 0.307461 & 0.527257 \\
\hline H & -0.909228 & -3.723966 & -1.073599 & $\mathrm{~N}$ & 2.017261 & 1.274201 & -0.411095 \\
\hline $\mathrm{H}$ & 2.541689 & -0.426856 & -2.521350 & C & 3.265958 & 1.769801 & -0.615893 \\
\hline $\mathrm{H}$ & -0.336213 & 1.071070 & -2.058289 & $C$ & 4.345559 & 1.345016 & 0.105819 \\
\hline $\mathrm{H}$ & 1.826604 & 3.722223 & -0.706026 & $C$ & 4.191754 & 0.334445 & 1.100558 \\
\hline $\mathrm{H}$ & 0.194344 & 3.364563 & -1.529842 & $\mathrm{~N}$ & 5.227405 & -0.119209 & 1.813938 \\
\hline $\mathrm{H}$ & 5.774557 & 1.601545 & -0.676755 & C & 6.563475 & 0.427297 & 1.598395 \\
\hline $\mathrm{H}$ & 3.619755 & 2.353205 & -1.567275 & $C$ & 5.030313 & -1.176227 & 2.801566 \\
\hline $\mathrm{H}$ & 1.448305 & 0.041286 & 1.097386 & 0 & -3.078996 & -0.954302 & 0.336994 \\
\hline $\mathrm{H}$ & 3.539042 & -0.895417 & 2.107145 & C & -4.080355 & -1.310191 & 1.327670 \\
\hline $\mathrm{H}$ & 5.510706 & -2.080655 & 2.115851 & $\mathrm{C}$ & -5.066977 & -0.151660 & 1.222897 \\
\hline $\mathrm{H}$ & 7.045888 & -1.405649 & 2.694007 & C & -3.458521 & -1.351949 & 2.720613 \\
\hline $\mathrm{H}$ & 5.513781 & -0.753768 & 3.305586 & C & -4.752834 & -2.627648 & 0.955692 \\
\hline $\mathrm{H}$ & 7.408815 & 0.085388 & -0.246117 & $C$ & -1.954502 & -1.657311 & 0.178637 \\
\hline $\mathrm{H}$ & 7.413750 & 1.376269 & 0.984012 & 0 & -1.744648 & -2.754652 & 0.682248 \\
\hline $\mathrm{H}$ & 8.118553 & -0.209208 & 1.350286 & $\mathrm{C}$ & -1.950551 & 1.421851 & -0.467847 \\
\hline $\mathrm{H}$ & -4.954818 & 0.980477 & 1.217786 & $C$ & -1.556530 & 1.571432 & 0.866075 \\
\hline $\mathrm{H}$ & -5.957392 & 0.054925 & 2.364270 & C & -2.037997 & 2.621770 & 1.645581 \\
\hline $\mathrm{H}$ & -4.273933 & 0.462722 & 2.774510 & C & -2.924090 & 3.553668 & 1.099076 \\
\hline $\mathrm{H}$ & -4.092784 & -3.183832 & 1.899434 & C & -3.328567 & 3.410471 & -0.227277 \\
\hline $\mathrm{H}$ & -5.414574 & -2.392979 & 2.789303 & C & -2.846188 & 2.349716 & -0.998459 \\
\hline $\mathrm{H}$ & -3.728035 & -1.979613 & 3.158241 & $\mathrm{H}$ & 3.248135 & -2.651128 & -3.121636 \\
\hline $\mathrm{H}$ & -6.413320 & -1.553201 & 0.480383 & $\mathrm{H}$ & 2.053867 & -4.270410 & -1.672283 \\
\hline $\mathrm{H}$ & -5.322260 & -0.691845 & -0.622358 & $\mathrm{H}$ & 0.014137 & -3.606543 & -0.435077 \\
\hline $\mathrm{H}$ & -5.090089 & -2.431484 & -0.315492 & $\mathrm{H}$ & 2.383006 & -0.316096 & -3.336813 \\
\hline $\mathrm{H}$ & -2.788435 & 0.640206 & -2.040715 & $\mathrm{H}$ & -0.125765 & 1.093849 & -2.946437 \\
\hline $\mathrm{H}$ & -4.528178 & 2.377412 & -2.314041 & $\mathrm{H}$ & 1.340974 & 3.762447 & -0.820731 \\
\hline $\mathrm{H}$ & -4.743746 & 4.205386 & -0.639319 & $\mathrm{H}$ & -0.031735 & 3.420020 & -2.032968 \\
\hline $\mathrm{H}$ & -3.203364 & 4.269514 & 1.311765 & $\mathrm{H}$ & 2.650112 & -0.939231 & 2.012327 \\
\hline $\mathrm{H}$ & -1.466677 & 2.480879 & 1.580791 & $\mathrm{H}$ & 0.828337 & -0.059745 & 0.651790 \\
\hline INT2p & & & & $\mathrm{H}$ & 3.356953 & 2.510020 & -1.401347 \\
\hline c & 2.354466 & -2.346738 & -2.585516 & $\mathrm{H}$ & 5.309626 & 1.780372 & -0.119568 \\
\hline c & 1.679699 & -3.254934 & -1.769690 & $\mathrm{H}$ & 6.578811 & 1.504096 & 1.794485 \\
\hline C & 0.524295 & -2.894502 & -1.068863 & $\mathrm{H}$ & 7.255668 & -0.059003 & 2.282490 \\
\hline c & 0.045406 & -1.586389 & -1.200483 & $\mathrm{H}$ & 6.898339 & 0.245097 & 0.571985 \\
\hline C & 0.722275 & -0.668390 & -2.022072 & $\mathrm{H}$ & 4.347655 & -0.847892 & 3.592031 \\
\hline C & 1.868159 & -1.040704 & -2.709336 & $\mathrm{H}$ & 4.624704 & -2.076655 & 2.329525 \\
\hline $\mathrm{N}$ & -1.057166 & -0.969613 & -0.595721 & $\mathrm{H}$ & 5.990978 & -1.420707 & 3.249950 \\
\hline
\end{tabular}




\begin{tabular}{|c|c|c|c|c|c|c|c|}
\hline $\mathrm{H}$ & -5.478357 & -0.093658 & 0.210697 & C & -3.973128 & -2.817247 & 1.015587 \\
\hline $\mathrm{H}$ & -5.888743 & -0.293179 & 1.931281 & c & -4.836302 & -2.839933 & 2.106644 \\
\hline $\mathrm{H}$ & -4.563793 & 0.795649 & 1.445746 & c & -4.823275 & -1.789745 & 3.026695 \\
\hline $\mathrm{H}$ & -2.755590 & -2.181059 & 2.819904 & c & -3.947561 & -0.718335 & 2.851136 \\
\hline $\mathrm{H}$ & -4.251923 & -1.473926 & 3.464874 & c & -3.087429 & -0.690199 & 1.755571 \\
\hline $\mathrm{H}$ & -2.938032 & -0.410227 & 2.927051 & H & -5.111505 & 1.753808 & -2.260617 \\
\hline $\mathrm{H}$ & -5.606927 & -2.797648 & 1.619402 & $\mathrm{H}$ & -4.039460 & 3.961652 & -1.826519 \\
\hline $\mathrm{H}$ & -5.120846 & -2.582989 & -0.074251 & $\mathrm{H}$ & -1.773480 & 4.094039 & -0.867931 \\
\hline $\mathrm{H}$ & -4.059530 & -3.465046 & 1.048842 & $\mathrm{H}$ & -3.867959 & -0.323148 & -1.704787 \\
\hline $\mathrm{H}$ & -0.892060 & 0.842452 & 1.321686 & $\mathrm{H}$ & -0.790403 & -0.313715 & 0.284730 \\
\hline $\mathrm{H}$ & -1.728398 & 2.708780 & 2.683976 & $\mathrm{H}$ & 0.407837 & -0.872023 & -3.684022 \\
\hline $\mathrm{H}$ & -3.300406 & 4.373372 & 1.704519 & $\mathrm{H}$ & -1.302612 & -0.176025 & -3.410607 \\
\hline $\mathrm{H}$ & -4.026288 & 4.121170 & -0.662528 & $\mathrm{H}$ & 3.431565 & -0.698321 & 0.870243 \\
\hline $\mathrm{H}$ & -3.166009 & 2.210193 & -2.026596 & H & 1.346885 & 0.248576 & -0.071880 \\
\hline INT3 & & & & $\mathrm{H}$ & 0.580974 & -3.196118 & -2.252604 \\
\hline C & -4.114387 & 1.811487 & -1.835737 & $\mathrm{H}$ & 2.625940 & -4.306082 & -1.443695 \\
\hline C & -3.507982 & 3.042722 & -1.590266 & $\mathrm{H}$ & 4.914341 & -4.574305 & -1.186694 \\
\hline C & -2.226268 & 3.128340 & -1.047357 & H & 5.665972 & -4.794268 & 0.404456 \\
\hline C & -1.490190 & 1.962276 & -0.723110 & $\mathrm{H}$ & 3.967808 & -5.244877 & 0.168197 \\
\hline C & -2.133329 & 0.711183 & -0.971384 & H & 5.592479 & -1.521124 & 0.773146 \\
\hline C & -3.409524 & 0.647327 & -1.519450 & $\mathrm{H}$ & 4.648444 & -2.174355 & 2.137260 \\
\hline $\mathrm{N}$ & -0.216958 & 1.877918 & -0.205067 & H & 6.049573 & -3.066170 & 1.514394 \\
\hline c & -2.179227 & -1.772692 & -0.356654 & $\mathrm{H}$ & 4.254974 & 2.006787 & 0.482112 \\
\hline 0 & -2.091138 & -2.773336 & -1.047311 & $\mathrm{H}$ & 4.780211 & 3.242960 & 1.645652 \\
\hline $\mathrm{C}$ & -1.334163 & -0.531830 & -0.643511 & $\mathrm{H}$ & 3.645383 & 1.973328 & 2.154384 \\
\hline C & -0.293587 & -0.829944 & -1.698431 & H & 1.485957 & 5.019456 & 1.826923 \\
\hline C & -0.399721 & -0.619335 & -3.003803 & H & 3.145528 & 4.962212 & 2.467160 \\
\hline c & 2.844077 & -1.299587 & 0.189561 & $\mathrm{H}$ & 1.977189 & 3.705939 & 2.921570 \\
\hline C & 1.693844 & -0.758486 & -0.312694 & H & 4.052546 & 4.972424 & -0.012436 \\
\hline$N$ & 0.911238 & -1.453031 & -1.183776 & $\mathrm{H}$ & 3.418183 & 3.751480 & -1.133231 \\
\hline C & 1.263583 & -2.704819 & -1.569164 & $\mathrm{H}$ & 2.361768 & 5.062640 & -0.560851 \\
\hline C & 2.401188 & -3.304183 & -1.104185 & H & -3.971059 & -3.627511 & 0.293166 \\
\hline c & 3.248719 & -2.614841 & -0.186783 & $\mathrm{H}$ & -5.519239 & -3.673229 & 2.240370 \\
\hline $\mathrm{N}$ & 4.363784 & -3.173808 & 0.297673 & H & -5.496574 & -1.805626 & 3.878696 \\
\hline C & 4.744141 & -4.523289 & -0.106266 & H & -3.936293 & 0.100302 & 3.563835 \\
\hline C & 5.207588 & -2.437013 & 1.233425 & $\mathrm{H}$ & -2.420148 & 0.157085 & 1.628558 \\
\hline 0 & 1.745992 & 2.558566 & 0.539341 & INT4 & & & \\
\hline C & 2.760012 & 3.514202 & 0.913840 & C & -4.508883 & -0.052794 & -1.730077 \\
\hline C & 3.933918 & 2.627695 & 1.325155 & C & -4.680081 & 1.231267 & -1.213202 \\
\hline C & 2.306992 & 4.357609 & 2.105116 & C & -3.637077 & 1.846837 & -0.524165 \\
\hline C & 3.166530 & 4.384516 & -0.275260 & C & -2.419541 & 1.183629 & -0.362490 \\
\hline C & 0.505414 & 2.966611 & 0.078953 & C & -2.211970 & -0.109698 & -0.892793 \\
\hline 0 & 0.234311 & 4.169691 & -0.009142 & C & -3.286225 & -0.702191 & -1.573786 \\
\hline C & -3.094034 & -1.742943 & 0.831723 & $\mathrm{~N}$ & -1.380120 & 1.758100 & 0.398836 \\
\hline
\end{tabular}




\begin{tabular}{|c|c|c|c|c|c|c|c|}
\hline C & -0.818213 & -2.151209 & -0.298881 & $\mathrm{H}$ & 2.762218 & 3.309234 & 1.341684 \\
\hline 0 & 0.162537 & -2.912379 & -0.488298 & $\mathrm{H}$ & 2.822828 & 5.014107 & 1.839068 \\
\hline C & -0.908144 & -0.807505 & -0.759919 & H & 1.872186 & 3.848100 & 2.784729 \\
\hline C & 0.227400 & -0.164001 & -1.384070 & H & -0.728373 & 5.804009 & 0.918861 \\
\hline C & 0.232140 & 0.864891 & -2.258367 & $\mathrm{H}$ & 0.749552 & 6.430667 & 1.678892 \\
\hline C & 3.081764 & -1.128172 & 0.787082 & $\mathrm{H}$ & -0.233212 & 5.222676 & 2.527409 \\
\hline C & 1.854924 & -0.711036 & 0.351635 & $\mathrm{H}$ & 2.068050 & 5.648439 & -0.484621 \\
\hline$N$ & 1.550283 & -0.624809 & -0.963129 & $\mathrm{H}$ & 1.944640 & 3.942346 & -0.955261 \\
\hline C & 2.470360 & -0.993290 & -1.882445 & H & 0.542703 & 5.023101 & -1.145072 \\
\hline C & 3.717568 & -1.431483 & -1.526966 & $\mathrm{H}$ & -1.752213 & -4.644659 & -0.405480 \\
\hline C & 4.079158 & -1.517434 & -0.152678 & $\mathrm{H}$ & -3.575967 & -5.696434 & 0.922112 \\
\hline $\mathrm{N}$ & 5.287173 & -1.949483 & 0.236914 & $\mathrm{H}$ & -4.777756 & -4.365729 & 2.644278 \\
\hline C & 6.269579 & -2.369830 & -0.755422 & $\mathrm{H}$ & -4.153333 & -1.989456 & 3.021708 \\
\hline C & 5.599814 & -2.067561 & 1.656662 & $\mathrm{H}$ & -2.376438 & -0.941131 & 1.661407 \\
\hline 0 & 0.235583 & 3.173275 & 0.916297 & INT5 & & & \\
\hline C & 0.966315 & 4.438153 & 0.907903 & C & -2.464529 & -3.571632 & -2.204050 \\
\hline C & 2.181944 & 4.130330 & 1.773903 & C & -3.639427 & -2.913916 & -1.822526 \\
\hline C & 0.126235 & 5.541203 & 1.543522 & C & -3.597188 & -1.685108 & -1.178153 \\
\hline C & 1.399090 & 4.782639 & -0.513441 & C & -2.368886 & -1.042359 & -0.873597 \\
\hline C & -0.920761 & 3.038201 & 0.239922 & C & -1.183298 & -1.707716 & -1.305632 \\
\hline 0 & -1.481315 & 3.914698 & -0.390904 & C & -1.246472 & -2.958445 & -1.933838 \\
\hline C & -1.959482 & -2.722109 & 0.518637 & $\mathrm{~N}$ & -2.234750 & 0.096169 & -0.116797 \\
\hline C & -2.297280 & -4.067119 & 0.335593 & C & 1.176750 & -1.990285 & -0.379877 \\
\hline C & -3.313768 & -4.655107 & 1.086657 & 0 & 2.228266 & -2.265794 & -0.935492 \\
\hline C & -3.989415 & -3.908607 & 2.053271 & c & 0.154758 & -1.111952 & -1.067684 \\
\hline C & -3.641736 & -2.573119 & 2.261734 & C & 0.497604 & 0.121065 & -1.464536 \\
\hline c & -2.638154 & -1.983017 & 1.494727 & c & -0.315409 & 1.099532 & -2.243231 \\
\hline $\mathrm{H}$ & -5.318111 & -0.541925 & -2.264167 & C & 3.237914 & 1.402131 & 0.674173 \\
\hline $\mathrm{H}$ & -5.624808 & 1.752641 & -1.335119 & C & 2.020948 & 0.952577 & 0.243328 \\
\hline H & -3.762051 & 2.835786 & -0.097435 & $\mathrm{~N}$ & 1.798516 & 0.630195 & -1.056145 \\
\hline $\mathrm{H}$ & -3.143598 & -1.693857 & -1.996030 & C & 2.795553 & 0.766355 & -1.965157 \\
\hline $\mathrm{H}$ & -0.694107 & 1.096135 & 0.746333 & C & 4.036446 & 1.212270 & -1.609130 \\
\hline $\mathrm{H}$ & 1.157074 & 1.351413 & -2.549375 & C & 4.314038 & 1.549592 & -0.250218 \\
\hline H & -0.699310 & 1.245796 & -2.662357 & $\mathrm{~N}$ & 5.518481 & 1.983968 & 0.134447 \\
\hline H & 3.260720 & -1.163758 & 1.853054 & C & 6.591998 & 2.135855 & -0.843275 \\
\hline $\mathrm{H}$ & 1.063265 & -0.430328 & 1.036738 & C & 5.766257 & 2.311774 & 1.535248 \\
\hline $\mathrm{H}$ & 2.150913 & -0.937477 & -2.915795 & 0 & -2.940795 & 1.964762 & 0.850162 \\
\hline $\mathrm{H}$ & 4.398907 & -1.723963 & -2.314154 & C & -3.780124 & 3.127122 & 1.004172 \\
\hline $\mathrm{H}$ & 6.492682 & -1.554821 & -1.451065 & C & -3.107402 & 3.890149 & 2.143672 \\
\hline $\mathrm{H}$ & 7.188666 & -2.646934 & -0.242737 & C & -5.199949 & 2.738027 & 1.416327 \\
\hline $\mathrm{H}$ & 5.909195 & -3.234850 & -1.322965 & C & -3.773263 & 3.983706 & -0.262166 \\
\hline $\mathrm{H}$ & 5.531552 & -1.094370 & 2.153470 & C & -3.206539 & 1.013242 & -0.113757 \\
\hline $\mathrm{H}$ & 4.917891 & -2.768063 & 2.150526 & 0 & -4.206476 & 1.117631 & -0.839035 \\
\hline $\mathrm{H}$ & 6.617098 & -2.439313 & 1.760998 & C & 0.849838 & -2.516114 & 0.978163 \\
\hline
\end{tabular}




\begin{tabular}{|c|c|c|c|c|c|c|c|}
\hline C & 1.637595 & -3.542790 & 1.513114 & C & 2.167661 & 0.819648 & -0.984844 \\
\hline C & 1.375438 & -4.025875 & 2.790516 & 0 & 1.580243 & 1.687148 & -1.692948 \\
\hline C & 0.331863 & -3.477838 & 3.541393 & $C$ & 1.530476 & -0.304842 & -0.451264 \\
\hline C & -0.449067 & -2.449624 & 3.013137 & $\mathrm{C}$ & 0.087611 & -0.563519 & -0.817870 \\
\hline c & -0.197837 & -1.968615 & 1.728946 & C & -0.110147 & -0.830683 & -2.309921 \\
\hline $\mathrm{H}$ & -2.499919 & -4.535523 & -2.701480 & C & -2.089552 & 2.545245 & -0.787216 \\
\hline H & -4.604657 & -3.372700 & -2.023098 & $C$ & -1.346312 & 1.474154 & -1.214391 \\
\hline H & -4.517002 & -1.195142 & -0.882550 & $\mathrm{~N}$ & -0.780858 & 0.605959 & -0.353750 \\
\hline H & -0.319119 & -3.446419 & -2.229449 & C & -0.913125 & 0.815053 & 0.975353 \\
\hline $\mathrm{H}$ & 0.279729 & 1.510303 & -3.067170 & C & -1.641702 & 1.854863 & 1.484035 \\
\hline $\mathrm{H}$ & -1.209426 & 0.624980 & -2.648233 & C & -2.278105 & 2.776280 & 0.602361 \\
\hline $\mathrm{H}$ & 3.351503 & 1.642598 & 1.722483 & $\mathrm{~N}$ & -3.007465 & 3.804928 & 1.060109 \\
\hline $\mathrm{H}$ & 1.173240 & 0.832887 & 0.909993 & C & -3.170386 & 4.008120 & 2.495001 \\
\hline $\mathrm{H}$ & 2.552504 & 0.481006 & -2.982500 & C & -3.614527 & 4.742762 & 0.123463 \\
\hline $\mathrm{H}$ & 4.793266 & 1.285691 & -2.378190 & 0 & -2.390824 & -1.589092 & -0.644070 \\
\hline $\mathrm{H}$ & 6.310990 & 2.853493 & -1.620944 & C & -3.795676 & -1.985223 & -0.744683 \\
\hline $\mathrm{H}$ & 7.479421 & 2.504512 & -0.333363 & C & -4.389792 & -0.863372 & -1.587540 \\
\hline $\mathrm{H}$ & 6.830480 & 1.175447 & -1.311555 & C & -4.438050 & -2.008727 & 0.637828 \\
\hline $\mathrm{H}$ & 5.116599 & 3.129142 & 1.864707 & C & -3.908709 & -3.322833 & -1.466183 \\
\hline $\mathrm{H}$ & 5.596482 & 1.439192 & 2.173874 & c & -1.507938 & -2.314490 & 0.053902 \\
\hline $\mathrm{H}$ & 6.802357 & 2.625714 & 1.643207 & 0 & -1.762778 & -3.330832 & 0.674022 \\
\hline $\mathrm{H}$ & -2.080027 & 4.153976 & 1.872504 & C & 3.638604 & 1.024980 & -0.721839 \\
\hline $\mathrm{H}$ & -3.658161 & 4.810194 & 2.362304 & C & 4.587566 & 0.148454 & -1.256458 \\
\hline $\mathrm{H}$ & -3.079677 & 3.276011 & 3.049414 & C & 5.949328 & 0.370972 & -1.052360 \\
\hline $\mathrm{H}$ & -5.718921 & 2.227634 & 0.604500 & C & 6.373058 & 1.466729 & -0.298895 \\
\hline $\mathrm{H}$ & -5.761509 & 3.637427 & 1.691574 & C & 5.430225 & 2.346962 & 0.235163 \\
\hline H & -5.167078 & 2.075702 & 2.288357 & $\mathrm{C}$ & 4.069906 & 2.132200 & 0.014314 \\
\hline H & -4.276699 & 4.936302 & -0.064621 & $\mathrm{H}$ & 4.165447 & -2.764506 & 2.638739 \\
\hline $\mathrm{H}$ & -2.741440 & 4.198971 & -0.561947 & $\mathrm{H}$ & 2.243729 & -4.294064 & 3.001535 \\
\hline H & -4.281615 & 3.475825 & -1.082534 & $\mathrm{H}$ & 0.095745 & -3.899232 & 1.800569 \\
\hline H & 2.446004 & -3.954257 & 0.916359 & $\mathrm{H}$ & 3.990544 & -0.870050 & 1.078889 \\
\hline $\mathrm{H}$ & 1.979709 & -4.828195 & 3.202680 & $\mathrm{H}$ & -1.160289 & -0.925881 & -2.592750 \\
\hline $\mathrm{H}$ & 0.127357 & -3.855343 & 4.539069 & $\mathrm{H}$ & 0.396622 & -1.774919 & -2.522017 \\
\hline $\mathrm{H}$ & -1.259084 & -2.023905 & 3.597240 & $\mathrm{H}$ & 0.371322 & -0.042918 & -2.891445 \\
\hline H & -0.812001 & -1.166975 & 1.318200 & $\mathrm{H}$ & -2.512493 & 3.201868 & -1.535323 \\
\hline $\mathrm{H}$ & -0.622650 & 1.929560 & -1.596636 & $\mathrm{H}$ & -1.184230 & 1.296037 & -2.267302 \\
\hline INT6 & & & & $\mathrm{H}$ & -0.411500 & 0.107416 & 1.626093 \\
\hline C & 3.233108 & -2.601837 & 2.105020 & $\mathrm{H}$ & -1.708232 & 1.955672 & 2.558828 \\
\hline C & 2.156748 & -3.459116 & 2.313295 & $\mathrm{H}$ & -2.204923 & 4.195035 & 2.977474 \\
\hline C & 0.943077 & -3.247682 & 1.639279 & $\mathrm{H}$ & -3.812766 & 4.871799 & 2.655530 \\
\hline C & 0.859494 & -2.178587 & 0.760498 & $\mathrm{H}$ & -3.637909 & 3.134772 & 2.961510 \\
\hline C & 1.947682 & -1.303946 & 0.508594 & $\mathrm{H}$ & -4.322641 & 4.231905 & -0.537798 \\
\hline C & 3.138553 & -1.526429 & 1.214831 & $\mathrm{H}$ & -4.151579 & 5.502927 & 0.687215 \\
\hline$N$ & -0.260065 & -1.738653 & 0.000699 & $\mathrm{H}$ & -2.850289 & 5.235318 & -0.487219 \\
\hline
\end{tabular}




\begin{tabular}{|c|c|c|c|c|c|c|c|}
\hline $\mathrm{H}$ & -3.887589 & -0.803563 & -2.558427 & H & 4.946193 & 0.278515 & -1.046275 \\
\hline $\mathrm{H}$ & -5.453950 & -1.050261 & -1.756550 & H & 5.388653 & -1.419360 & -0.793069 \\
\hline $\mathrm{H}$ & -4.279816 & 0.097922 & -1.074872 & H & 4.095356 & -1.011744 & -1.935516 \\
\hline $\mathrm{H}$ & -4.063245 & -2.835659 & 1.242078 & $\mathrm{H}$ & 3.912140 & -1.284324 & 2.159962 \\
\hline $\mathrm{H}$ & -5.520971 & -2.118561 & 0.523624 & H & 3.069795 & -2.565559 & 1.250192 \\
\hline $\mathrm{H}$ & -4.242812 & -1.065689 & 1.159770 & H & 4.807313 & -2.299773 & 1.015271 \\
\hline $\mathrm{H}$ & -4.964098 & -3.533913 & -1.664254 & $\mathrm{H}$ & -4.481727 & 0.234337 & 1.077472 \\
\hline $\mathrm{H}$ & -3.381446 & -3.281251 & -2.424883 & INT8 & & & \\
\hline $\mathrm{H}$ & -3.496595 & -4.135785 & -0.866292 & C & -3.509475 & 0.929804 & 0.869551 \\
\hline $\mathrm{H}$ & 4.254587 & -0.715326 & -1.827468 & C & -2.963920 & 0.000004 & 0.000013 \\
\hline $\mathrm{H}$ & 6.678986 & -0.312970 & -1.476548 & C & -3.509504 & -0.929793 & -0.869510 \\
\hline $\mathrm{H}$ & 7.432738 & 1.636233 & -0.131480 & C & 0.568056 & 1.184108 & -0.246424 \\
\hline $\mathrm{H}$ & 5.755528 & 3.202253 & 0.820684 & C & -0.801665 & 1.143476 & -0.235223 \\
\hline $\mathrm{H}$ & 3.333264 & 2.821153 & 0.419802 & $\mathrm{~N}$ & -1.483634 & -0.000001 & -0.000008 \\
\hline INT7 & & & & c & -0.801667 & -1.143480 & 0.235202 \\
\hline$C$ & -2.164777 & -2.060099 & -0.982016 & C & 0.568054 & -1.184121 & 0.246374 \\
\hline C & -3.360854 & -2.577799 & -0.481847 & C & 1.319058 & -0.000012 & -0.000049 \\
\hline$C$ & -4.189700 & -1.720129 & 0.253637 & $\mathrm{~N}$ & 2.661408 & -0.000018 & -0.000084 \\
\hline C & -3.821053 & -0.405431 & 0.495796 & C & 3.392559 & -1.239434 & 0.233481 \\
\hline $\mathrm{C}$ & -2.597762 & 0.147583 & 0.017485 & C & 3.392549 & 1.239452 & -0.233392 \\
\hline $\mathrm{C}$ & -1.791784 & -0.737605 & -0.753993 & H & -4.582253 & 1.086886 & 0.883497 \\
\hline $\mathrm{C}$ & -2.294676 & 1.519486 & 0.317817 & H & -2.908437 & -1.378951 & -1.652220 \\
\hline $\mathrm{C}$ & -1.091640 & 2.226954 & 0.115458 & $\mathrm{H}$ & -4.582282 & -1.086870 & -0.883426 \\
\hline C & -0.875727 & 3.572154 & -0.010185 & $\mathrm{H}$ & 1.051036 & 2.128377 & -0.458966 \\
\hline C & 1.514679 & -0.219942 & 1.154628 & H & -1.413949 & 2.017058 & -0.424310 \\
\hline $\mathrm{C}$ & 0.383331 & 0.547660 & 1.114376 & H & -1.413953 & -2.017054 & 0.424319 \\
\hline $\mathrm{N}$ & 0.144084 & 1.421426 & 0.108191 & $\mathrm{H}$ & 1.051032 & -2.128385 & 0.458940 \\
\hline $\mathrm{C}$ & 1.042105 & 1.540531 & -0.896889 & H & 3.126470 & -1.995809 & -0.512324 \\
\hline C & 2.194434 & 0.801407 & -0.932434 & $\mathrm{H}$ & 4.459130 & -1.037848 & 0.155716 \\
\hline C & 2.482182 & -0.123422 & 0.112562 & H & 3.183669 & -1.636809 & 1.232634 \\
\hline $\mathrm{N}$ & 3.599083 & -0.864168 & 0.113049 & H & 3.183406 & 1.637183 & -1.232345 \\
\hline C & 4.557228 & -0.742804 & -0.979606 & $\mathrm{H}$ & 3.126693 & 1.995581 & 0.512752 \\
\hline C & 3.855614 & -1.804688 & 1.198216 & $\mathrm{H}$ & 4.459133 & 1.037789 & -0.156007 \\
\hline $\mathrm{H}$ & -1.512020 & -2.691548 & -1.580883 & H & -2.908385 & 1.378958 & 1.652245 \\
\hline $\mathrm{H}$ & -3.646821 & -3.607822 & -0.669516 & INT9 & & & \\
\hline $\mathrm{H}$ & -5.135893 & -2.085589 & 0.646146 & C & -2.692383 & 0.853485 & 0.310172 \\
\hline $\mathrm{H}$ & -0.876041 & -0.380049 & -1.214967 & C & -1.580799 & 1.739830 & 0.275278 \\
\hline $\mathrm{H}$ & -3.120017 & 2.122163 & 0.687433 & C & -1.564630 & 3.094365 & 0.357779 \\
\hline $\mathrm{H}$ & 0.117912 & 3.995262 & 0.091091 & C & 1.339452 & -0.414476 & 1.061790 \\
\hline $\mathrm{H}$ & -1.718655 & 4.245996 & -0.113996 & C & 0.103321 & 0.169099 & 1.084056 \\
\hline $\mathrm{H}$ & 1.644514 & -0.894129 & 1.990294 & $\mathrm{~N}$ & -0.258265 & 1.114731 & 0.186640 \\
\hline $\mathrm{H}$ & -0.382989 & 0.500959 & 1.879662 & C & 0.602938 & 1.466807 & -0.793855 \\
\hline $\mathrm{H}$ & 0.778125 & 2.244304 & -1.677189 & c & 1.850890 & 0.912115 & -0.896688 \\
\hline $\mathrm{H}$ & 2.862392 & 0.934418 & -1.772814 & C & 2.277806 & -0.062068 & 0.049950 \\
\hline
\end{tabular}




\begin{tabular}{|c|c|c|c|c|c|c|c|}
\hline $\mathrm{N}$ & 3.495535 & -0.621292 & -0.010391 & C & 4.992280 & -3.061321 & 1.413998 \\
\hline C & 4.416686 & -0.254972 & -1.079404 & 0 & 1.399471 & 2.654168 & 1.100570 \\
\hline $\mathrm{C}$ & 3.893776 & -1.618009 & 0.976667 & c & 2.728979 & 3.148447 & 0.732246 \\
\hline $\mathrm{H}$ & -3.641163 & 1.266352 & 0.630322 & C & 3.623036 & 2.520949 & 1.793625 \\
\hline $\mathrm{H}$ & -0.635671 & 3.641310 & 0.473829 & C & 2.772047 & 4.669253 & 0.823923 \\
\hline $\mathrm{H}$ & -2.497187 & 3.647505 & 0.359039 & C & 3.104721 & 2.636959 & -0.654708 \\
\hline $\mathrm{H}$ & 1.570127 & -1.152436 & 1.817812 & C & 0.314916 & 2.987182 & 0.379850 \\
\hline $\mathrm{H}$ & -0.646635 & -0.081561 & 1.824852 & 0 & 0.295023 & 3.713563 & -0.592797 \\
\hline $\mathrm{H}$ & 0.237095 & 2.204825 & -1.497235 & C & -2.900496 & -2.099701 & 0.292054 \\
\hline $\mathrm{H}$ & 2.485598 & 1.229201 & -1.713030 & C & -3.496639 & -3.317035 & -0.062118 \\
\hline $\mathrm{H}$ & 4.659759 & 0.812170 & -1.038163 & C & -4.460775 & -3.890050 & 0.759829 \\
\hline $\mathrm{H}$ & 5.335871 & -0.825191 & -0.960647 & C & -4.836288 & -3.251526 & 1.943677 \\
\hline $\mathrm{H}$ & 3.987817 & -0.484761 & -2.060520 & C & -4.246694 & -2.039564 & 2.302383 \\
\hline $\mathrm{H}$ & 3.852255 & -1.202665 & 1.988958 & C & -3.282726 & -1.462264 & 1.479426 \\
\hline $\mathrm{H}$ & 3.246155 & -2.499994 & 0.927019 & H & -5.182071 & 1.834390 & -1.986759 \\
\hline $\mathrm{H}$ & 4.917524 & -1.924673 & 0.771096 & $\mathrm{H}$ & -4.660749 & 4.017024 & -0.912985 \\
\hline C & -2.678395 & -0.480221 & -0.157976 & H & -2.595569 & 4.247725 & 0.468742 \\
\hline 0 & -1.740665 & -1.131181 & -0.642597 & $\mathrm{H}$ & -3.661730 & -0.081423 & -1.700324 \\
\hline 0 & -3.913373 & -1.080921 & -0.015365 & H & -0.957661 & -0.209365 & 0.751420 \\
\hline C & -3.999135 & -2.420554 & -0.475369 & $\mathrm{H}$ & 1.048938 & 1.022349 & -2.675197 \\
\hline $\mathrm{H}$ & -3.319124 & -3.076712 & 0.076136 & H & -0.715765 & 1.573789 & -2.444248 \\
\hline $\mathrm{H}$ & -5.030769 & -2.731136 & -0.301643 & $\mathrm{H}$ & 3.173700 & -1.350713 & 1.750383 \\
\hline $\mathrm{H}$ & -3.767394 & -2.491902 & -1.542274 & $\mathrm{H}$ & 1.258219 & 0.031034 & 1.115765 \\
\hline INT3NH & & & & $\mathrm{H}$ & 1.048905 & -1.674729 & -2.665343 \\
\hline C & -4.287400 & 1.947273 & -1.382824 & $\mathrm{H}$ & 2.995593 & -3.113135 & -2.236125 \\
\hline C & -3.995032 & 3.169861 & -0.782462 & $\mathrm{H}$ & 5.229651 & -3.520052 & -1.784043 \\
\hline C & -2.843927 & 3.304882 & -0.008452 & $\mathrm{H}$ & 5.739765 & -4.596288 & -0.469468 \\
\hline C & -1.985972 & 2.221593 & 0.158352 & $\mathrm{H}$ & 4.136276 & -4.801766 & -1.197400 \\
\hline C & -2.268921 & 0.984471 & -0.445186 & $\mathrm{H}$ & 5.388241 & -2.054834 & 1.583382 \\
\hline C & -3.427290 & 0.862374 & -1.214177 & $\mathrm{H}$ & 4.281670 & -3.306961 & 2.208872 \\
\hline $\mathrm{N}$ & -0.791551 & 2.375894 & 0.918225 & $\mathrm{H}$ & 5.815328 & -3.771659 & 1.452565 \\
\hline C & -1.871936 & -1.528386 & -0.629329 & $\mathrm{H}$ & 3.554805 & 1.428630 & 1.754688 \\
\hline 0 & -1.495664 & -2.137058 & -1.614098 & $\mathrm{H}$ & 4.662839 & 2.810670 & 1.619342 \\
\hline C & -1.271695 & -0.151911 & -0.299690 & $\mathrm{H}$ & 3.328956 & 2.857140 & 2.792349 \\
\hline C & -0.031459 & 0.080792 & -1.135725 & $\mathrm{H}$ & 2.165820 & 5.135425 & 0.046093 \\
\hline C & 0.108022 & 0.937815 & -2.139928 & $\mathrm{H}$ & 3.807953 & 5.002579 & 0.708193 \\
\hline C & 2.749498 & -1.469460 & 0.762455 & $\mathrm{H}$ & 2.414417 & 4.999359 & 1.804422 \\
\hline C & 1.672249 & -0.700679 & 0.428182 & $\mathrm{H}$ & 4.149505 & 2.892004 & -0.857371 \\
\hline $\mathrm{N}$ & 1.084276 & -0.781485 & -0.796462 & $\mathrm{H}$ & 3.007106 & 1.545475 & -0.697308 \\
\hline C & 1.576504 & -1.649277 & -1.720097 & $\mathrm{H}$ & 2.478501 & 3.083542 & -1.428578 \\
\hline c & 2.655833 & -2.443249 & -1.458390 & $\mathrm{H}$ & -3.196171 & -3.801583 & -0.985585 \\
\hline C & 3.298266 & -2.387970 & -0.185098 & $\mathrm{H}$ & -4.921391 & -4.832036 & 0.479354 \\
\hline$N$ & 4.353349 & -3.151622 & 0.103492 & $\mathrm{H}$ & -5.589884 & -3.697994 & 2.585345 \\
\hline C & 4.891505 & -4.068292 & -0.898864 & $\mathrm{H}$ & -4.539611 & -1.540757 & 3.220698 \\
\hline
\end{tabular}




\begin{tabular}{|c|c|c|c|c|c|c|c|}
\hline $\mathrm{H}$ & -2.842377 & -0.513905 & 1.772050 & H & 0.278829 & 2.018200 & -0.660624 \\
\hline $\mathrm{H}$ & -0.620017 & 1.734181 & 1.683190 & $\mathrm{H}$ & 2.086987 & -1.587250 & -1.701884 \\
\hline INT3CH & & & & $\mathrm{H}$ & 4.313303 & -0.623833 & -1.535664 \\
\hline C & -4.583952 & -1.981367 & -1.295209 & $\mathrm{H}$ & 6.088693 & 0.830311 & -2.009139 \\
\hline$C$ & -3.917163 & -3.183918 & -1.054561 & $\mathrm{H}$ & 6.886621 & 1.755952 & -0.722806 \\
\hline C & -2.535610 & -3.215509 & -0.843426 & H & 6.044446 & 0.248529 & -0.322887 \\
\hline C & -1.853806 & -2.009165 & -0.867993 & H & 4.459285 & 3.971438 & -1.054374 \\
\hline C & -2.511051 & -0.802753 & -1.113282 & $\mathrm{H}$ & 4.434473 & 3.470533 & 0.657905 \\
\hline C & -3.881522 & -0.772577 & -1.327835 & H & 5.971544 & 3.569205 & -0.220761 \\
\hline $\mathrm{N}$ & -0.441554 & -1.797938 & -0.712425 & $\mathrm{H}$ & 3.041063 & -0.131821 & 1.745358 \\
\hline C & -1.540275 & 0.889198 & 0.342267 & H & 3.815244 & -1.274607 & 2.866774 \\
\hline 0 & -0.840918 & 0.401725 & 1.212967 & $\mathrm{H}$ & 3.856745 & -1.585945 & 1.118358 \\
\hline C & -1.488355 & 0.324709 & -1.081002 & $\mathrm{H}$ & 1.319327 & -4.034638 & 2.375041 \\
\hline C & -0.217227 & -0.495752 & -1.429945 & H & 2.902198 & -3.612884 & 3.060068 \\
\hline c & -0.220245 & -0.766355 & -2.943554 & $\mathrm{H}$ & 2.733358 & -3.838391 & 1.310195 \\
\hline C & 2.400835 & 2.076023 & -0.659434 & H & 1.683260 & -1.523087 & 4.143491 \\
\hline C & 1.191454 & 1.455864 & -0.798345 & $\mathrm{H}$ & 0.894455 & -0.362098 & 3.051509 \\
\hline $\mathrm{N}$ & 1.081333 & 0.147118 & -1.135762 & H & 0.169776 & -1.961637 & 3.325756 \\
\hline$C$ & 2.218435 & -0.552451 & -1.409834 & H & -2.034206 & 1.891170 & 2.740291 \\
\hline c & 3.459192 & -0.000377 & -1.307690 & $\mathrm{H}$ & -3.587961 & 3.729360 & 3.363620 \\
\hline c & 3.609823 & 1.354679 & -0.885672 & $\mathrm{H}$ & -4.925872 & 4.864487 & 1.605098 \\
\hline $\mathrm{N}$ & 4.809454 & 1.914062 & -0.719658 & $\mathrm{H}$ & -4.711398 & 4.161489 & -0.764803 \\
\hline c & 6.023581 & 1.137754 & -0.960520 & $\mathrm{H}$ & -3.182613 & 2.343391 & -1.385309 \\
\hline C & 4.918322 & 3.312339 & -0.310918 & H & -1.175158 & -1.180522 & -3.268319 \\
\hline 0 & 1.276213 & -1.703447 & 0.784304 & H & -1.669263 & 1.088416 & -1.839229 \\
\hline c & 1.945825 & -1.971799 & 2.067431 & INT4CH & & & \\
\hline C & 3.246908 & -1.190596 & 1.936297 & C & -2.409413 & -3.863422 & -1.769930 \\
\hline C & 2.232118 & -3.462233 & 2.208011 & c & -3.577520 & -3.103221 & -1.770931 \\
\hline $\mathrm{C}$ & 1.110842 & -1.421053 & 3.216289 & C & -3.539216 & -1.737751 & -1.506450 \\
\hline C & 0.066529 & -2.191271 & 0.541280 & C & -2.319724 & -1.106376 & -1.230689 \\
\hline 0 & -0.538971 & -2.964122 & 1.251727 & C & -1.127818 & -1.863432 & -1.248946 \\
\hline C & -2.497612 & 1.995373 & 0.644581 & C & -1.196145 & -3.237442 & -1.508199 \\
\hline C & -2.622623 & 2.397767 & 1.982075 & $\mathrm{~N}$ & -2.250047 & 0.266912 & -0.940712 \\
\hline C & -3.492690 & 3.424958 & 2.326117 & C & 0.998733 & -1.937231 & 0.161394 \\
\hline C & -4.245514 & 4.062061 & 1.336551 & 0 & 2.075589 & -2.446126 & -0.093891 \\
\hline C & -4.126202 & 3.668149 & 0.004641 & c & 0.209660 & -1.276666 & -0.958044 \\
\hline C & -3.255047 & 2.637630 & -0.343646 & C & 0.772494 & -0.309415 & -1.698946 \\
\hline $\mathrm{H}$ & -5.656290 & -1.983519 & -1.462301 & C & 0.226648 & 0.318108 & -2.942014 \\
\hline $\mathrm{H}$ & -4.477425 & -4.113471 & -1.035989 & c & 3.324239 & 1.293238 & 0.451600 \\
\hline $\mathrm{H}$ & -2.013286 & -4.147122 & -0.659704 & C & 2.135039 & 0.837542 & -0.036380 \\
\hline $\mathrm{H}$ & -4.398263 & 0.164095 & -1.514742 & $N$ & 2.038833 & 0.238250 & -1.254495 \\
\hline $\mathrm{H}$ & -0.043754 & 0.175347 & -3.470575 & c & 3.150750 & 0.107462 & -2.026766 \\
\hline $\mathrm{H}$ & 0.567898 & -1.474321 & -3.205114 & C & 4.372843 & 0.542402 & -1.605839 \\
\hline $\mathrm{H}$ & 2.402956 & 3.121312 & -0.382355 & C & 4.518440 & 1.147122 & -0.319132 \\
\hline
\end{tabular}




\begin{tabular}{|c|c|c|c|c|c|c|c|}
\hline$N$ & 5.703140 & 1.553016 & 0.136470 & H & -0.967873 & -2.068641 & 5.149312 \\
\hline C & 6.899354 & 1.405995 & -0.689914 & $\mathrm{H}$ & -1.988971 & -0.550925 & 3.471093 \\
\hline C & 5.818957 & 2.126832 & 1.475452 & H & -1.118130 & -0.490550 & 1.164980 \\
\hline 0 & -2.728043 & 2.250873 & -0.113030 & $\mathrm{H}$ & -0.687412 & -0.181095 & -3.265535 \\
\hline C & -3.547536 & 3.297884 & 0.508361 & $\mathrm{H} 2 \mathrm{O}$ & & & \\
\hline C & -2.577204 & 4.467836 & 0.604205 & 0 & 0.000000 & -0.000000 & 0.116929 \\
\hline c & -3.990297 & 2.853578 & 1.897656 & H & 0.000000 & 0.767276 & -0.467716 \\
\hline C & -4.723268 & 3.649159 & -0.395899 & $\mathrm{H}$ & -0.000000 & -0.767276 & -0.467716 \\
\hline C & -3.239174 & 1.038628 & -0.372650 & $\mathrm{OH}-$ & & & \\
\hline 0 & -4.375094 & 0.675519 & -0.147521 & 0 & -0.000000 & -0.000000 & 0.107232 \\
\hline C & 0.417417 & -1.972915 & 1.532570 & H & 0.000000 & 0.000000 & -0.857855 \\
\hline C & 0.997166 & -2.822400 & 2.483370 & 9 & & & \\
\hline C & 0.496833 & -2.858010 & 3.780125 & C & 1.527385 & 1.451218 & -0.000014 \\
\hline C & -0.577641 & -2.039062 & 4.136495 & C & 2.599453 & 0.554705 & 0.000020 \\
\hline C & -1.153357 & -1.186214 & 3.194762 & c & 2.349165 & -0.816561 & 0.000048 \\
\hline C & -0.660184 & -1.155572 & 1.892445 & C & 1.037047 & -1.288548 & 0.000003 \\
\hline $\mathrm{H}$ & -2.440848 & -4.928501 & -1.973609 & C & -0.043015 & -0.396876 & -0.000041 \\
\hline $\mathrm{H}$ & -4.533890 & -3.572181 & -1.980827 & C & 0.218105 & 0.981423 & -0.000039 \\
\hline $\mathrm{H}$ & -4.450867 & -1.156125 & -1.504884 & C & -1.419011 & -0.936272 & -0.000047 \\
\hline H & -0.275739 & -3.816289 & -1.510137 & c & -2.514983 & -0.210538 & 0.000017 \\
\hline $\mathrm{H}$ & -1.339199 & 0.706008 & -0.955408 & C & -3.601545 & 0.514762 & 0.000065 \\
\hline H & 0.025048 & 1.383578 & -2.779995 & $\mathrm{H}$ & 1.714269 & 2.521111 & -0.000019 \\
\hline $\mathrm{H}$ & 0.959198 & 0.246834 & -3.753018 & H & 3.620268 & 0.924520 & 0.000038 \\
\hline $\mathrm{H}$ & 3.328713 & 1.763284 & 1.425658 & H & 3.175023 & -1.521887 & 0.000098 \\
\hline $\mathrm{H}$ & 1.208438 & 0.931166 & 0.520563 & $\mathrm{H}$ & -0.611687 & 1.683744 & -0.000061 \\
\hline $\mathrm{H}$ & 3.015655 & -0.388184 & -2.981071 & $\mathrm{H}$ & -1.518331 & -2.021374 & -0.000172 \\
\hline H & 5.220221 & 0.395738 & -2.261549 & $\mathrm{H}$ & -4.069236 & 0.826080 & 0.931912 \\
\hline H & 6.786427 & 1.951642 & -1.631531 & H & -4.069049 & 0.826156 & -0.931883 \\
\hline H & 7.749880 & 1.816536 & -0.150172 & $\mathrm{H}$ & 0.843132 & -2.358226 & 0.000016 \\
\hline$H$ & 7.093562 & 0.350648 & -0.905972 & 15 & & & \\
\hline $\mathrm{H}$ & 5.248796 & 3.058097 & 1.549417 & C & 1.308006 & -0.000009 & 0.000027 \\
\hline $\mathrm{H}$ & 5.456328 & 1.420848 & 2.228693 & $\mathrm{H}$ & 1.867131 & -0.659861 & 0.658616 \\
\hline $\mathrm{H}$ & 6.866694 & 2.340835 & 1.674113 & H & 1.867317 & 0.659687 & -0.658554 \\
\hline H & -2.227830 & 4.760809 & -0.390364 & C & 0.000000 & 0.000047 & -0.000036 \\
\hline $\mathrm{H}$ & -3.078980 & 5.323924 & 1.063276 & c & -1.308006 & 0.000057 & -0.000063 \\
\hline $\mathrm{H}$ & -1.712039 & 4.201019 & 1.218837 & H & -1.867236 & 0.659275 & 0.659071 \\
\hline H & -4.704729 & 2.030559 & 1.848264 & $\mathrm{H}$ & -1.867217 & -0.659668 & -0.658703 \\
\hline $\mathrm{H}$ & -4.465710 & 3.698265 & 2.405381 & 16 & & & \\
\hline H & -3.123129 & 2.543626 & 2.490196 & C & 0.858560 & 0.992822 & 0.000020 \\
\hline $\mathrm{H}$ & -5.219962 & 4.539880 & 0.000696 & C & 1.856354 & 0.137677 & -0.000233 \\
\hline H & -4.369291 & 3.877065 & -1.406389 & c & 2.854286 & -0.698532 & 0.000065 \\
\hline $\mathrm{H}$ & -5.450532 & 2.837640 & -0.444803 & $\mathrm{H}$ & 1.037666 & 2.064244 & 0.000118 \\
\hline $\mathrm{H}$ & 1.832440 & -3.451241 & 2.191222 & $\mathrm{H}$ & 3.277721 & -1.058424 & 0.934610 \\
\hline $\mathrm{H}$ & 0.940182 & -3.523584 & 4.514001 & $\mathrm{H}$ & 3.278125 & -1.058662 & -0.934204 \\
\hline
\end{tabular}




\begin{tabular}{|c|c|c|c|c|c|c|c|}
\hline C & -0.565191 & 0.582314 & 0.000033 & H & 4.265201 & 1.354918 & 1.408235 \\
\hline 0 & -1.482511 & 1.377225 & 0.000008 & $\mathrm{H}$ & 1.167679 & 4.839042 & -0.257164 \\
\hline 0 & -0.736575 & -0.743505 & 0.000071 & $\mathrm{H}$ & 0.169429 & 1.243804 & -0.968504 \\
\hline C & -2.097593 & -1.192062 & -0.000042 & $\mathrm{H}$ & -2.246443 & 4.652492 & -0.967716 \\
\hline $\mathrm{H}$ & -2.615879 & -0.835344 & -0.892713 & $\mathrm{H}$ & -0.742626 & 4.850735 & -2.055644 \\
\hline $\mathrm{H}$ & -2.047357 & -2.279674 & 0.000043 & H & -5.394795 & 1.152201 & -1.729100 \\
\hline $\mathrm{H}$ & -2.616083 & -0.835212 & 0.892458 & $\mathrm{H}$ & -3.521927 & 2.739949 & -2.027666 \\
\hline TS1 & & & & $\mathrm{H}$ & -1.378867 & 1.101083 & 1.075593 \\
\hline C & 3.032331 & 4.445854 & 0.730506 & $\mathrm{H}$ & -3.128811 & -0.573300 & 1.561028 \\
\hline C & 3.930311 & 3.478358 & 1.188937 & H & -5.227786 & -1.322187 & 2.199995 \\
\hline C & 3.600222 & 2.134101 & 1.044170 & $\mathrm{H}$ & -6.169329 & -2.439870 & 1.195354 \\
\hline C & 2.401921 & 1.766965 & 0.441124 & $\mathrm{H}$ & -4.402328 & -2.399552 & 1.048449 \\
\hline C & 1.486593 & 2.721046 & -0.051060 & $\mathrm{H}$ & -7.149486 & 0.208323 & -0.581136 \\
\hline C & 1.841637 & 4.074643 & 0.117625 & H & -6.402239 & -0.944329 & -1.713787 \\
\hline$N$ & 2.071443 & 0.365855 & 0.358772 & $\mathrm{H}$ & -7.320437 & -1.535124 & -0.317148 \\
\hline C & 1.058578 & -0.107248 & 1.218080 & $\mathrm{H}$ & 1.886127 & -4.087874 & -0.001475 \\
\hline 0 & 0.787662 & 0.504586 & 2.233743 & $\mathrm{H}$ & 3.383262 & -4.943801 & -0.441573 \\
\hline C & 0.252232 & 2.292302 & -0.701113 & H & 3.309227 & -4.000176 & 1.063097 \\
\hline C & -0.809525 & 3.091307 & -0.938274 & H & 5.334220 & -1.802406 & -1.208090 \\
\hline C & -1.303973 & 4.260282 & -1.336491 & H & 5.443886 & -3.571777 & -1.099395 \\
\hline C & -4.538478 & 1.096208 & -1.069201 & $\mathrm{H}$ & 5.304877 & -2.605199 & 0.382085 \\
\hline C & -3.495663 & 1.985792 & -1.241662 & H & 3.344455 & -3.742238 & -2.662997 \\
\hline$N$ & -2.398049 & 1.976863 & -0.482242 & $\mathrm{H}$ & 1.868751 & -2.880409 & -2.197216 \\
\hline C & -2.297184 & 1.067474 & 0.490118 & $\mathrm{H}$ & 3.302035 & -1.971465 & -2.745110 \\
\hline C & -3.278398 & 0.132927 & 0.753538 & $\mathrm{H}$ & 0.398489 & -0.939580 & -1.336329 \\
\hline c & -4.453962 & 0.117713 & -0.042838 & $\mathrm{H}$ & -1.157469 & -2.758245 & -1.934556 \\
\hline $\mathrm{N}$ & -5.440388 & -0.786097 & 0.164221 & $\mathrm{H}$ & -2.190950 & -4.153707 & -0.156969 \\
\hline c & -5.297686 & -1.787220 & 1.209433 & $\mathrm{H}$ & -1.675647 & -3.700107 & 2.231497 \\
\hline C & -6.638502 & -0.758232 & -0.659427 & H & -0.149169 & -1.830048 & 2.834240 \\
\hline 0 & 2.847883 & -1.713006 & 0.009740 & TS2 & & & \\
\hline C & 3.468717 & -2.812353 & -0.740121 & C & 1.817687 & -3.080023 & -1.645569 \\
\hline C & 2.980305 & -4.038173 & 0.020336 & C & 0.743540 & -3.800972 & -1.125967 \\
\hline C & 4.984223 & -2.680237 & -0.661655 & C & -0.402972 & -3.129477 & -0.693240 \\
\hline C & 2.962271 & -2.839037 & -2.177581 & C & -0.467054 & -1.744143 & -0.798583 \\
\hline C & 2.896774 & -0.457499 & -0.422564 & C & 0.590480 & -0.989199 & -1.361867 \\
\hline 0 & 3.581058 & -0.029738 & -1.325153 & C & 1.738027 & -1.692526 & -1.765668 \\
\hline c & 0.231682 & -1.281125 & 0.793014 & $\mathrm{~N}$ & -1.538218 & -0.964779 & -0.270192 \\
\hline C & -0.051930 & -1.541640 & -0.551029 & C & -1.117809 & 0.225920 & 0.491673 \\
\hline C & -0.929484 & -2.568165 & -0.890121 & 0 & -0.447820 & 0.055602 & 1.501515 \\
\hline C & -1.512330 & -3.348785 & 0.109880 & C & 0.385168 & 0.451991 & -1.434796 \\
\hline C & -1.225013 & -3.093354 & 1.451787 & C & 1.352709 & 1.464074 & -1.254957 \\
\hline C & -0.365444 & -2.051638 & 1.793640 & C & 1.258179 & 2.797589 & -1.531895 \\
\hline H & 3.269240 & 5.500578 & 0.838805 & C & 4.967539 & 0.899140 & -0.585852 \\
\hline $\mathrm{H}$ & 4.866223 & 3.765583 & 1.656993 & C & 3.792856 & 1.296979 & -1.165256 \\
\hline
\end{tabular}




\begin{tabular}{|c|c|c|c|c|c|c|c|}
\hline $\mathrm{N}$ & 2.591850 & 1.049533 & -0.591315 & $\mathrm{H}$ & -5.381873 & 0.325502 & -0.782414 \\
\hline C & 2.536552 & 0.386279 & 0.589105 & $\mathrm{H}$ & -5.433213 & -1.429801 & -1.093267 \\
\hline C & 3.668911 & -0.040032 & 1.228753 & H & -2.961980 & 0.826033 & -1.494939 \\
\hline C & 4.950731 & 0.199235 & 0.655504 & H & -3.989667 & 3.022507 & -1.934971 \\
\hline $\mathrm{N}$ & 6.078956 & -0.215286 & 1.248273 & $\mathrm{H}$ & -3.379744 & 4.993798 & -0.544089 \\
\hline C & 6.016346 & -0.941503 & 2.511947 & H & -1.718959 & 4.741038 & 1.287372 \\
\hline C & 7.371979 & 0.044254 & 0.625746 & $\mathrm{H}$ & -0.701376 & 2.516495 & 1.741339 \\
\hline 0 & -3.489807 & -0.733224 & 0.775481 & TS2p & & & \\
\hline C & -4.932635 & -0.882893 & 0.954777 & C & -2.303145 & -1.519183 & 3.178231 \\
\hline C & -5.257976 & 0.228720 & 1.944936 & C & -1.491632 & -2.586062 & 2.792184 \\
\hline C & -5.243844 & -2.250023 & 1.553341 & C & -0.315251 & -2.358232 & 2.080647 \\
\hline c & -5.658796 & -0.648382 & -0.365573 & C & 0.040360 & -1.050115 & 1.744073 \\
\hline C & -2.811611 & -1.467762 & -0.116822 & C & -0.742554 & 0.051753 & 2.153317 \\
\hline 0 & -3.250559 & -2.431354 & -0.718704 & C & -1.918679 & -0.215392 & 2.865737 \\
\hline C & -1.773139 & 1.525182 & 0.169737 & $\mathrm{~N}$ & 1.188743 & -0.729898 & 0.970929 \\
\hline C & -2.696233 & 1.678170 & -0.875204 & C & 1.867291 & 0.511949 & 1.348585 \\
\hline C & -3.270448 & 2.917963 & -1.127734 & 0 & 2.334716 & 0.590980 & 2.479391 \\
\hline C & -2.927479 & 4.026693 & -0.345536 & c & -0.303709 & 1.406065 & 1.742477 \\
\hline C & -1.998750 & 3.883995 & 0.681940 & C & -1.016337 & 2.174183 & 0.794055 \\
\hline C & -1.421685 & 2.638457 & 0.938436 & C & -0.839218 & 3.472026 & 0.406524 \\
\hline $\mathrm{H}$ & 2.713280 & -3.598581 & -1.976201 & C & -2.749132 & -0.425424 & -1.235493 \\
\hline $\mathrm{H}$ & 0.796160 & -4.881851 & -1.038905 & C & -1.781813 & 0.309244 & -0.605221 \\
\hline $\mathrm{H}$ & -1.231132 & -3.678842 & -0.260839 & $\mathrm{~N}$ & -2.066143 & 1.450452 & 0.065663 \\
\hline $\mathrm{H}$ & 2.564760 & -1.143235 & -2.209918 & C & -3.348384 & 1.879387 & 0.129807 \\
\hline $\mathrm{H}$ & -0.531359 & 0.782050 & -1.908375 & C & -4.372346 & 1.201207 & -0.475335 \\
\hline $\mathrm{H}$ & 2.010250 & 3.498816 & -1.188837 & C & -4.108506 & -0.001744 & -1.191794 \\
\hline $\mathrm{H}$ & 0.398290 & 3.176365 & -2.073987 & $\mathrm{~N}$ & -5.086214 & -0.699683 & -1.785823 \\
\hline $\mathrm{H}$ & 5.891947 & 1.120655 & -1.101857 & C & -6.466914 & -0.236787 & -1.709561 \\
\hline H & 3.761999 & 1.814217 & -2.116647 & C & -4.779254 & -1.943742 & -2.482886 \\
\hline $\mathrm{H}$ & 1.542341 & 0.220777 & 0.994586 & 0 & 3.031965 & -1.257775 & -0.161693 \\
\hline $\mathrm{H}$ & 3.554299 & -0.558172 & 2.171136 & C & 3.819246 & -1.901282 & -1.213417 \\
\hline H & 7.028845 & -1.186414 & 2.826104 & C & 5.088516 & -1.058838 & -1.233490 \\
\hline $\mathrm{H}$ & 5.547137 & -0.330535 & 3.290033 & c & 3.099771 & -1.809154 & -2.554993 \\
\hline $\mathrm{H}$ & 5.449572 & -1.871609 & 2.399279 & C & 4.127234 & -3.341180 & -0.819023 \\
\hline H & 7.427937 & -0.417398 & -0.365752 & C & 1.776245 & -1.630213 & 0.103054 \\
\hline $\mathrm{H}$ & 7.550488 & 1.120408 & 0.528456 & 0 & 1.219311 & -2.613383 & -0.352278 \\
\hline H & 8.154327 & -0.381884 & 1.250731 & C & 2.213991 & 1.480871 & 0.267820 \\
\hline $\mathrm{H}$ & -4.984975 & 1.203180 & 1.526844 & C & 1.786858 & 1.357382 & -1.059716 \\
\hline $\mathrm{H}$ & -6.329474 & 0.227450 & 2.164531 & C & 2.167246 & 2.294930 & -2.016255 \\
\hline H & -4.708041 & 0.082985 & 2.879559 & C & 2.971404 & 3.379907 & -1.660394 \\
\hline $\mathrm{H}$ & -5.039169 & -3.051348 & 0.841669 & C & 3.380680 & 3.522646 & -0.335197 \\
\hline $\mathrm{H}$ & -6.301786 & -2.286693 & 1.831830 & c & 3.005614 & 2.579625 & 0.621364 \\
\hline $\mathrm{H}$ & -4.645668 & -2.411335 & 2.455827 & H & -3.220737 & -1.700561 & 3.730209 \\
\hline H & -6.737488 & -0.645272 & -0.180263 & $\mathrm{H}$ & -1.770095 & -3.604822 & 3.045502 \\
\hline
\end{tabular}




\begin{tabular}{|c|c|c|c|c|c|c|c|}
\hline $\mathrm{H}$ & 0.306309 & -3.189535 & 1.771538 & $\mathrm{~N}$ & 1.661453 & -1.594364 & -0.395554 \\
\hline $\mathrm{H}$ & -2.536200 & 0.623515 & 3.178096 & C & 2.895095 & -1.646922 & 0.170900 \\
\hline H & 0.350043 & 1.970172 & 2.397649 & c & 3.933495 & -0.884026 & -0.282520 \\
\hline H & -1.383659 & 3.887205 & -0.433613 & $\mathrm{C}$ & 3.739351 & 0.008903 & -1.378169 \\
\hline $\mathrm{H}$ & -0.125391 & 4.099289 & 0.929201 & $N$ & 4.721459 & 0.800410 & -1.823383 \\
\hline $\mathrm{H}$ & -2.448125 & -1.326188 & -1.753411 & C & 6.023624 & 0.795869 & -1.164120 \\
\hline $\mathrm{H}$ & -0.740716 & 0.012137 & -0.610143 & C & 4.489513 & 1.690636 & -2.956389 \\
\hline $\mathrm{H}$ & -3.511825 & 2.784743 & 0.702049 & 0 & -2.326026 & 1.528053 & -0.238933 \\
\hline $\mathrm{H}$ & -5.374587 & 1.595499 & -0.376256 & C & -3.318135 & 2.559997 & -0.458311 \\
\hline H & -6.570643 & 0.756650 & -2.158037 & C & -4.430333 & 1.804860 & -1.181142 \\
\hline $\mathrm{H}$ & -7.099724 & -0.932458 & -2.256663 & C & -2.768683 & 3.668264 & -1.353859 \\
\hline $\mathrm{H}$ & -6.809422 & -0.195741 & -0.670191 & C & -3.828842 & 3.100103 & 0.874943 \\
\hline $\mathrm{H}$ & -4.082726 & -1.766649 & -3.308846 & C & -1.182746 & 1.771314 & 0.443243 \\
\hline $\mathrm{H}$ & -4.340343 & -2.676923 & -1.798058 & 0 & -0.841375 & 2.903600 & 0.778864 \\
\hline $\mathrm{H}$ & -5.701752 & -2.353760 & -2.889374 & C & -2.292585 & -1.468548 & 0.019185 \\
\hline $\mathrm{H}$ & 5.586119 & -1.091839 & -0.259712 & C & -2.117721 & -1.097215 & -1.315495 \\
\hline $\mathrm{H}$ & 5.776186 & -1.442893 & -1.992334 & C & -2.873686 & -1.688507 & -2.326022 \\
\hline $\mathrm{H}$ & 4.849106 & -0.016596 & -1.468976 & C & -3.822869 & -2.665529 & -2.018115 \\
\hline $\mathrm{H}$ & 2.182732 & -2.400752 & -2.562399 & C & -4.017627 & -3.033021 & -0.687779 \\
\hline $\mathrm{H}$ & 3.765127 & -2.188283 & -3.336964 & C & -3.259328 & -2.434242 & 0.320111 \\
\hline $\mathrm{H}$ & 2.862146 & -0.766053 & -2.787354 & $\mathrm{H}$ & 3.383738 & -0.043547 & 4.169565 \\
\hline $\mathrm{H}$ & 4.844451 & -3.761960 & -1.530770 & $\mathrm{H}$ & 3.076667 & 2.205721 & 3.161508 \\
\hline $\mathrm{H}$ & 4.575970 & -3.371085 & 0.178881 & $\mathrm{H}$ & 1.273276 & 2.627659 & 1.529001 \\
\hline $\mathrm{H}$ & 3.225449 & -3.955740 & -0.823458 & H & 1.912796 & -1.926924 & 3.427327 \\
\hline $\mathrm{H}$ & 1.169861 & 0.516434 & -1.362255 & H & -0.330178 & -2.551663 & 2.119738 \\
\hline $\mathrm{H}$ & 1.835635 & 2.175949 & -3.043961 & H & 0.743054 & -3.868356 & -1.239038 \\
\hline $\mathrm{H}$ & 3.267380 & 4.109657 & -2.407991 & H & -0.592681 & -4.083969 & 0.046095 \\
\hline $\mathrm{H}$ & 3.999732 & 4.366256 & -0.043792 & H & 2.212763 & 0.617212 & -2.836443 \\
\hline $\mathrm{H}$ & 3.331561 & 2.676698 & 1.652075 & $\mathrm{H}$ & 0.462249 & -0.815087 & -1.889952 \\
\hline TS3p & & & & $\mathrm{H}$ & 3.005890 & -2.335809 & 0.998814 \\
\hline C & 2.609300 & 0.123382 & 3.427091 & H & 4.889767 & -0.977210 & 0.213894 \\
\hline C & 2.429418 & 1.385278 & 2.862022 & H & 6.500689 & -0.186384 & -1.246318 \\
\hline C & 1.415559 & 1.634091 & 1.931271 & H & 6.661712 & 1.534241 & -1.645133 \\
\hline C & 0.565169 & 0.587558 & 1.536118 & $\mathrm{H}$ & 5.922436 & 1.057552 & -0.105944 \\
\hline$C$ & 0.792831 & -0.699151 & 2.072805 & $\mathrm{H}$ & 4.221463 & 1.119537 & -3.851220 \\
\hline C & 1.780240 & -0.927130 & 3.018481 & H & 3.688750 & 2.403108 & -2.733675 \\
\hline $\mathrm{N}$ & -0.517018 & 0.604107 & 0.658545 & $\mathrm{H}$ & 5.403512 & 2.244744 & -3.159675 \\
\hline C & -1.474512 & -0.982561 & 1.210139 & H & -4.783560 & 0.968714 & -0.569061 \\
\hline 0 & -2.093501 & -0.713475 & 2.259714 & $\mathrm{H}$ & -5.270907 & 2.475832 & -1.382632 \\
\hline$C$ & -0.095257 & -1.729749 & 1.435646 & $\mathrm{H}$ & -4.065551 & 1.405347 & -2.133014 \\
\hline C & 0.559829 & -2.340031 & 0.204781 & H & -2.002183 & 4.249405 & -0.840035 \\
\hline C & 0.224381 & -3.495512 & -0.360858 & $\mathrm{H}$ & -3.586156 & 4.335900 & -1.645986 \\
\hline C & 2.447563 & 0.000070 & -1.980048 & $\mathrm{H}$ & -2.338761 & 3.236950 & -2.264493 \\
\hline C & 1.456293 & -0.789544 & -1.466272 & $\mathrm{H}$ & -4.686304 & 3.757189 & 0.696093 \\
\hline
\end{tabular}




\begin{tabular}{|c|c|c|c|c|c|c|c|}
\hline $\mathrm{H}$ & -4.154476 & 2.271971 & 1.512824 & $\mathrm{H}$ & -3.909509 & 2.023675 & -1.572868 \\
\hline $\mathrm{H}$ & -3.054570 & 3.664976 & 1.396517 & $\mathrm{H}$ & -2.711877 & -2.805029 & -1.914572 \\
\hline $\mathrm{H}$ & -1.423103 & -0.301399 & -1.553137 & $\mathrm{H}$ & -0.651405 & 0.115047 & -0.316165 \\
\hline $\mathrm{H}$ & -2.732443 & -1.374845 & -3.357020 & $\mathrm{H}$ & 1.124287 & -1.070164 & -3.778925 \\
\hline $\mathrm{H}$ & -4.412274 & -3.124644 & -2.806593 & $\mathrm{H}$ & -0.713049 & -1.328879 & -3.588949 \\
\hline $\mathrm{H}$ & -4.761573 & -3.782019 & -0.431098 & $\mathrm{H}$ & 3.448032 & 1.124387 & 0.653977 \\
\hline $\mathrm{H}$ & -3.414086 & -2.712514 & 1.358854 & $\mathrm{H}$ & 1.236059 & 0.804274 & -0.339680 \\
\hline TS4 & & & & $\mathrm{H}$ & 2.354286 & -2.781835 & -2.103247 \\
\hline$C$ & -4.221439 & -1.302884 & -2.305301 & $\mathrm{H}$ & 4.642076 & -2.623862 & -1.223933 \\
\hline C & -4.539992 & 0.050977 & -2.212163 & $\mathrm{H}$ & 6.742850 & -1.693677 & -0.978626 \\
\hline c & -3.649075 & 0.975742 & -1.656419 & $\mathrm{H}$ & 7.448722 & -1.328087 & 0.606019 \\
\hline c & -2.405173 & 0.529247 & -1.193751 & $\mathrm{H}$ & 6.210275 & -2.589277 & 0.468757 \\
\hline C & -2.070168 & -0.852513 & -1.302078 & $\mathrm{H}$ & 5.723913 & 1.484642 & 0.648826 \\
\hline c & -2.975713 & -1.751465 & -1.846149 & $\mathrm{H}$ & 5.184292 & 0.567127 & 2.079422 \\
\hline $\mathrm{N}$ & -1.384511 & 1.228353 & -0.577268 & $\mathrm{H}$ & 6.867665 & 0.456616 & 1.531344 \\
\hline c & -0.533593 & -2.198853 & 0.248668 & $\mathrm{H}$ & 2.153767 & 3.814105 & 0.628198 \\
\hline 0 & 0.409741 & -2.994287 & 0.246404 & $\mathrm{H}$ & 1.743306 & 5.070646 & 1.815027 \\
\hline C & -0.692180 & -1.155911 & -0.777011 & $\mathrm{H}$ & 1.460901 & 3.359071 & 2.203185 \\
\hline c & 0.377950 & -1.151622 & -1.803482 & $\mathrm{H}$ & -1.974222 & 4.692038 & 1.494701 \\
\hline c & 0.260632 & -1.190629 & -3.132288 & $\mathrm{H}$ & -0.669827 & 5.545639 & 2.349004 \\
\hline C & 3.269958 & 0.241795 & 0.054885 & $\mathrm{H}$ & -0.974438 & 3.831143 & 2.689700 \\
\hline C & 2.025920 & 0.072997 & -0.487060 & $\mathrm{H}$ & 0.389988 & 6.173290 & 0.007592 \\
\hline $\mathrm{N}$ & 1.724546 & -1.000825 & -1.260020 & $\mathrm{H}$ & 0.695491 & 4.856638 & -1.141568 \\
\hline C & 2.670899 & -1.938021 & -1.503072 & $\mathrm{H}$ & -0.976082 & 5.328415 & -0.756322 \\
\hline C & 3.938084 & -1.834407 & -0.998861 & $\mathrm{H}$ & -1.187502 & -4.379312 & 1.626690 \\
\hline C & 4.292098 & -0.724455 & -0.178338 & $\mathrm{H}$ & -2.822372 & -4.612066 & 3.490263 \\
\hline $\mathrm{N}$ & 5.516767 & -0.597029 & 0.347965 & $\mathrm{H}$ & -4.070624 & -2.618844 & 4.292652 \\
\hline C & 6.532461 & -1.612586 & 0.092915 & $\mathrm{H}$ & -3.684434 & -0.407293 & 3.229334 \\
\hline c & 5.835190 & 0.544573 & 1.199229 & $\mathrm{H}$ & -2.083693 & -0.186759 & 1.364211 \\
\hline 0 & -0.219604 & 2.860744 & 0.340503 & TS5 & & & \\
\hline C & 0.032827 & 4.208874 & 0.813085 & C & 2.722111 & 3.370153 & -1.972232 \\
\hline C & 1.436362 & 4.105119 & 1.402490 & C & 3.836214 & 2.562730 & -1.712847 \\
\hline C & -0.967012 & 4.591565 & 1.901573 & C & 3.673181 & 1.268869 & -1.240960 \\
\hline c & 0.026632 & 5.202868 & -0.346363 & C & 2.388156 & 0.738289 & -0.985259 \\
\hline c & -1.398014 & 2.535284 & -0.269404 & C & 1.251081 & 1.543178 & -1.281247 \\
\hline 0 & -2.289943 & 3.353182 & -0.484436 & C & 1.453358 & 2.851089 & -1.760905 \\
\hline c & -1.542375 & -2.280078 & 1.363553 & $\mathrm{~N}$ & 2.156661 & -0.545875 & -0.514095 \\
\hline c & -1.747828 & -3.518900 & 1.980082 & C & -1.110686 & 2.035618 & -0.461200 \\
\hline C & -2.659588 & -3.644063 & 3.025609 & 0 & -2.278105 & 2.107441 & -0.835209 \\
\hline c & -3.361136 & -2.524443 & 3.475729 & C & -0.138752 & 1.081273 & -1.061185 \\
\hline c & -3.147905 & -1.282715 & 2.875966 & C & -0.559930 & -0.155052 & -1.490078 \\
\hline c & -2.247890 & -1.160253 & 1.818658 & C & 0.233051 & -1.112012 & -2.203220 \\
\hline $\mathrm{H}$ & -4.931340 & -2.005101 & -2.731587 & c & -3.294483 & -1.125697 & 0.823475 \\
\hline $\mathrm{H}$ & -5.504289 & 0.401373 & -2.571191 & C & -2.0 & -0.701577 & 0.334737 \\
\hline
\end{tabular}




\begin{tabular}{|c|c|c|c|c|c|c|c|}
\hline $\mathrm{N}$ & -1.837310 & -0.645218 & -0.996005 & $\mathrm{H}$ & 4.670925 & -3.956671 & -0.798367 \\
\hline C & -2.790746 & -1.039428 & -1.875158 & $\mathrm{H}$ & 5.434999 & -2.903924 & 0.415902 \\
\hline C & -4.019977 & -1.470572 & -1.463072 & $\mathrm{H}$ & -2.124363 & 4.414483 & 0.213518 \\
\hline C & -4.331111 & -1.521184 & -0.071575 & $\mathrm{H}$ & -1.465572 & 5.894284 & 2.105117 \\
\hline $\mathrm{N}$ & -5.527452 & -1.925146 & 0.370685 & $\mathrm{H}$ & 0.360577 & 5.197837 & 3.637903 \\
\hline C & -6.566025 & -2.319447 & -0.575590 & $\mathrm{H}$ & 1.530361 & 3.037546 & 3.272697 \\
\hline C & -5.802417 & -1.969707 & 1.803422 & $\mathrm{H}$ & 0.902651 & 1.593132 & 1.363675 \\
\hline 0 & 2.658769 & -2.567274 & 0.220615 & TS6 & & & \\
\hline C & 3.428392 & -3.570901 & 0.929427 & C & -4.308858 & 2.351914 & -0.635380 \\
\hline C & 2.580363 & -4.828872 & 0.765367 & C & -3.615524 & 3.301971 & 0.113919 \\
\hline C & 3.551366 & -3.214266 & 2.409404 & C & -2.252043 & 3.156292 & 0.384748 \\
\hline C & 4.793128 & -3.774192 & 0.274598 & C & -1.549563 & 2.043649 & -0.105510 \\
\hline C & 3.089017 & -1.275254 & 0.138309 & C & -2.273911 & 1.053154 & -0.848518 \\
\hline 0 & 4.146599 & -0.898709 & 0.637620 & C & -3.628497 & 1.228748 & -1.114658 \\
\hline C & -0.650578 & 2.920173 & 0.664027 & $\mathrm{~N}$ & -0.218583 & 1.742869 & 0.078677 \\
\hline C & -1.320372 & 4.128217 & 0.885046 & C & -1.868635 & -1.505373 & -0.812673 \\
\hline C & -0.952584 & 4.950415 & 1.946686 & 0 & -1.276219 & -2.499891 & -1.253871 \\
\hline C & 0.074671 & 4.558773 & 2.807598 & C & -1.465005 & -0.146206 & -1.139960 \\
\hline C & 0.734787 & 3.346659 & 2.601735 & C & -0.136572 & 0.184930 & -1.403760 \\
\hline C & 0.380716 & 2.532563 & 1.527576 & C & 0.303621 & 1.160749 & -2.456338 \\
\hline $\mathrm{H}$ & 2.845517 & 4.383570 & -2.341483 & C & 1.843733 & -1.971545 & 0.824868 \\
\hline $\mathrm{H}$ & 4.838777 & 2.946716 & -1.881103 & C & 0.910343 & -1.105279 & 0.336147 \\
\hline $\mathrm{H}$ & 4.538678 & 0.652056 & -1.032726 & $\mathrm{~N}$ & 0.897384 & -0.720296 & -0.966999 \\
\hline $\mathrm{H}$ & 0.582275 & 3.466265 & -1.978672 & C & 1.862109 & -1.177764 & -1.805200 \\
\hline $\mathrm{H}$ & 1.226056 & -1.140125 & -1.305988 & C & 2.829422 & -2.045986 & -1.387998 \\
\hline $\mathrm{H}$ & 0.783353 & -0.703650 & -3.054198 & C & 2.857329 & -2.492135 & -0.032632 \\
\hline $\mathrm{H}$ & -0.246743 & -2.066943 & -2.407653 & $\mathrm{~N}$ & 3.791785 & -3.337616 & 0.412421 \\
\hline $\mathrm{H}$ & -3.428032 & -1.153763 & 1.896144 & c & 4.831568 & -3.825696 & -0.488154 \\
\hline $\mathrm{H}$ & -1.276339 & -0.397664 & 0.983141 & C & 3.773588 & -3.786878 & 1.801454 \\
\hline H & -2.522116 & -0.972594 & -2.923028 & 0 & 1.944015 & 1.978972 & 0.390870 \\
\hline $\mathrm{H}$ & -4.738549 & -1.759441 & -2.217902 & C & 3.177590 & 2.681104 & 0.665241 \\
\hline H & -6.248496 & -3.185871 & -1.164976 & c & 4.223639 & 1.572661 & 0.577376 \\
\hline $\mathrm{H}$ & -7.462827 & -2.585992 & -0.020164 & C & 3.165374 & 3.277575 & 2.071404 \\
\hline $\mathrm{H}$ & -6.807513 & -1.494212 & -1.252935 & C & 3.449965 & 3.741238 & -0.400262 \\
\hline H & -5.112988 & -2.652530 & 2.310507 & C & 0.734717 & 2.632352 & 0.372492 \\
\hline H & -5.711001 & -0.973709 & 2.248663 & 0 & 0.636018 & 3.842514 & 0.590990 \\
\hline $\mathrm{H}$ & -6.819108 & -2.326821 & 1.953331 & C & -3.071919 & -1.739157 & 0.065239 \\
\hline $\mathrm{H}$ & 2.458855 & -5.072145 & -0.294762 & C & -3.932657 & -2.797407 & -0.241849 \\
\hline $\mathrm{H}$ & 3.062105 & -5.674431 & 1.265164 & C & -5.020809 & -3.082852 & 0.580793 \\
\hline H & 1.588685 & -4.681602 & 1.204565 & C & -5.238482 & -2.328700 & 1.734852 \\
\hline $\mathrm{H}$ & 4.183821 & -2.337698 & 2.555410 & C & -4.367905 & -1.287409 & 2.060462 \\
\hline H & 3.987610 & -4.060035 & 2.951048 & C & -3.295150 & -0.985995 & 1.223522 \\
\hline $\mathrm{H}$ & 2.560472 & -3.013468 & 2.830758 & H & -5.365621 & 2.481974 & -0.847657 \\
\hline H & 5.280026 & -4.649636 & 0.716841 & $\mathrm{H}$ & -4.135831 & 4.180919 & 0.485985 \\
\hline
\end{tabular}




\begin{tabular}{|c|c|c|c|c|c|c|c|}
\hline $\mathrm{H}$ & -1.717256 & 3.905698 & 0.956223 & $\mathrm{~N}$ & -0.883046 & 0.789949 & -0.425171 \\
\hline $\mathrm{H}$ & -4.159304 & 0.473122 & -1.688957 & $\mathrm{C}$ & -0.497442 & 1.502112 & 0.640301 \\
\hline $\mathrm{H}$ & 0.394098 & 0.641824 & -3.419106 & $\mathrm{C}$ & -1.192230 & 2.595800 & 1.110803 \\
\hline $\mathrm{H}$ & -0.457127 & 1.932345 & -2.576334 & $\mathrm{C}$ & -2.370774 & 3.017141 & 0.440964 \\
\hline $\mathrm{H}$ & 1.804747 & -2.222210 & 1.876117 & $N$ & -3.089736 & 4.080167 & 0.863271 \\
\hline $\mathrm{H}$ & 0.148439 & -0.650064 & 0.956891 & $\mathrm{C}$ & -2.666176 & 4.822074 & 2.041329 \\
\hline $\mathrm{H}$ & 1.812547 & -0.841549 & -2.832301 & $\mathrm{C}$ & -4.283840 & 4.486330 & 0.138045 \\
\hline $\mathrm{H}$ & 3.556542 & -2.384134 & -2.113555 & 0 & -2.346361 & -1.802317 & -0.597552 \\
\hline $\mathrm{H}$ & 5.403878 & -2.992310 & -0.907487 & C & -3.665675 & -2.423284 & -0.789811 \\
\hline $\mathrm{H}$ & 5.509967 & -4.463977 & 0.073954 & $\mathrm{C}$ & -4.312685 & -1.519527 & -1.831570 \\
\hline $\mathrm{H}$ & 4.396818 & -4.409285 & -1.306139 & C & -4.454474 & -2.383100 & 0.513499 \\
\hline $\mathrm{H}$ & 3.916485 & -2.944190 & 2.485947 & C & -3.499313 & -3.836051 & -1.337090 \\
\hline $\mathrm{H}$ & 2.825806 & -4.281400 & 2.035643 & $\mathrm{C}$ & -1.448368 & -2.354867 & 0.213942 \\
\hline $\mathrm{H}$ & 4.582870 & -4.498913 & 1.949075 & 0 & -1.647576 & -3.298393 & 0.951034 \\
\hline $\mathrm{H}$ & 4.206496 & 1.112196 & -0.416376 & C & 3.780065 & 0.675318 & -0.989784 \\
\hline $\mathrm{H}$ & 5.223553 & 1.978998 & 0.757187 & C & 4.598531 & -0.458328 & -0.992177 \\
\hline $\mathrm{H}$ & 4.021144 & 0.796989 & 1.323386 & C & 5.978112 & -0.328882 & -0.839467 \\
\hline $\mathrm{H}$ & 2.448387 & 4.096177 & 2.146113 & $\mathrm{C}$ & 6.546021 & 0.933921 & -0.662418 \\
\hline $\mathrm{H}$ & 4.163495 & 3.655602 & 2.316517 & C & 5.732792 & 2.068595 & -0.659949 \\
\hline $\mathrm{H}$ & 2.902104 & 2.506376 & 2.803303 & C & 4.356234 & 1.939644 & -0.838421 \\
\hline $\mathrm{H}$ & 4.454562 & 4.153226 & -0.257814 & $\mathrm{H}$ & 3.721877 & -1.528986 & 3.605169 \\
\hline $\mathrm{H}$ & 3.404059 & 3.291968 & -1.398465 & $\mathrm{H}$ & 1.780738 & -2.964237 & 4.178599 \\
\hline $\mathrm{H}$ & 2.723131 & 4.552589 & -0.342990 & $\mathrm{H}$ & -0.150450 & -3.134361 & 2.622815 \\
\hline $\mathrm{H}$ & -3.741431 & -3.389830 & -1.131960 & $\mathrm{H}$ & 3.774646 & -0.265838 & 1.493850 \\
\hline $\mathrm{H}$ & -5.694697 & -3.895455 & 0.325886 & $\mathrm{H}$ & -1.233328 & -1.111157 & -2.435411 \\
\hline $\mathrm{H}$ & -6.082641 & -2.553309 & 2.380274 & $\mathrm{H}$ & 0.342832 & -1.890468 & -2.583137 \\
\hline $\mathrm{H}$ & -4.528194 & -0.704739 & 2.962651 & $\mathrm{H}$ & 0.204929 & -0.140035 & -2.859374 \\
\hline $\mathrm{H}$ & -2.628038 & -0.165213 & 1.473950 & $\mathrm{H}$ & -3.621809 & 2.513030 & -1.285857 \\
\hline $\mathrm{H}$ & 1.261587 & 1.621358 & -2.200320 & $\mathrm{H}$ & -2.273069 & 0.587161 & -1.945044 \\
\hline TS7 & & & & $\mathrm{H}$ & 0.420648 & 1.177072 & 1.123581 \\
\hline$C$ & 2.886413 & -1.610623 & 2.915667 & $\mathrm{H}$ & -0.816731 & 3.117207 & 1.981561 \\
\hline$C$ & 1.793976 & -2.414428 & 3.242708 & $\mathrm{H}$ & -1.672552 & 5.261479 & 1.897035 \\
\hline$C$ & 0.702206 & -2.518535 & 2.373134 & $\mathrm{H}$ & -3.375852 & 5.626995 & 2.224718 \\
\hline C & 0.754261 & -1.812814 & 1.177754 & $\mathrm{H}$ & -2.638677 & 4.175715 & 2.925868 \\
\hline$C$ & 1.855836 & -1.007246 & 0.811704 & $\mathrm{H}$ & -5.029633 & 3.683207 & 0.123776 \\
\hline$C$ & 2.923267 & -0.899924 & 1.714321 & $\mathrm{H}$ & -4.720158 & 5.352335 & 0.633167 \\
\hline $\mathrm{N}$ & -0.222735 & -1.699858 & 0.150155 & $\mathrm{H}$ & -4.045202 & 4.762050 & -0.895575 \\
\hline$C$ & 2.295411 & 0.563399 & -1.224220 & $\mathrm{H}$ & -3.711130 & -1.489750 & -2.745893 \\
\hline 0 & 1.791250 & 1.313236 & -2.080534 & $\mathrm{H}$ & -5.304487 & -1.905205 & -2.082967 \\
\hline$C$ & 1.545555 & -0.388272 & -0.466281 & $\mathrm{H}$ & -4.424168 & -0.502256 & -1.444406 \\
\hline$C$ & 0.193661 & -0.742580 & -0.821654 & $\mathrm{H}$ & -4.039093 & -3.063548 & 1.257509 \\
\hline$C$ & -0.168241 & -0.974717 & -2.267813 & $\mathrm{H}$ & -5.489414 & -2.674472 & 0.309206 \\
\hline$C$ & -2.747710 & 2.260519 & -0.699329 & $\mathrm{H}$ & -4.458832 & -1.366061 & 0.918986 \\
\hline$C$ & -1.986802 & 1.173844 & -1.079202 & $\mathrm{H}$ & -4.482837 & -4.221536 & -1.622285 \\
\hline
\end{tabular}




\begin{tabular}{|c|c|c|c|c|c|c|c|}
\hline $\mathrm{H}$ & -2.864848 & -3.824935 & -2.229620 & H & -3.555793 & 3.332529 & -0.197612 \\
\hline $\mathrm{H}$ & -3.064463 & -4.508388 & -0.596301 & $\mathrm{H}$ & -3.140309 & -1.293187 & -1.896035 \\
\hline $\mathrm{H}$ & 4.151382 & -1.442022 & -1.113278 & $\mathrm{H}$ & -0.741211 & -0.359750 & 0.873742 \\
\hline $\mathrm{H}$ & 6.609256 & -1.212662 & -0.853312 & $\mathrm{H}$ & 1.189614 & 1.227380 & -2.488629 \\
\hline $\mathrm{H}$ & 7.619600 & 1.033938 & -0.531739 & $\mathrm{H}$ & -0.660497 & 1.393595 & -2.381127 \\
\hline $\mathrm{H}$ & 6.172348 & 3.052678 & -0.525522 & H & 3.433050 & -1.299669 & 1.830249 \\
\hline H & 3.716921 & 2.817947 & -0.857383 & $\mathrm{H}$ & 1.275274 & -0.298760 & 1.225552 \\
\hline TS8 & & & & $\mathrm{H}$ & 1.792973 & -1.235203 & -2.787950 \\
\hline C & -4.356208 & 0.470953 & -1.847419 & H & 3.971982 & -2.284267 & -2.378843 \\
\hline C & -4.477269 & 1.779485 & -1.380770 & $\mathrm{H}$ & 6.197727 & -2.316216 & -1.754400 \\
\hline C & -3.480423 & 2.316299 & -0.571674 & $\mathrm{H}$ & 6.841399 & -3.460935 & -0.563556 \\
\hline C & -2.358936 & 1.558733 & -0.223970 & H & 5.381178 & -3.877246 & -1.478646 \\
\hline C & -2.220240 & 0.234148 & -0.689415 & $\mathrm{H}$ & 5.713244 & -1.483410 & 1.847191 \\
\hline C & -3.235407 & -0.282460 & -1.506078 & H & 4.929254 & -3.067248 & 2.077990 \\
\hline $\mathrm{N}$ & -1.353004 & 2.128322 & 0.591671 & H & 6.588899 & -2.974015 & 1.456900 \\
\hline C & -1.130794 & -2.048933 & -0.469612 & $\mathrm{H}$ & 2.739267 & 3.292226 & 2.009288 \\
\hline 0 & -0.371099 & -2.747834 & -1.135720 & $\mathrm{H}$ & 3.164427 & 5.011193 & 1.842564 \\
\hline C & -0.977139 & -0.566799 & -0.375060 & H & 1.805875 & 4.527319 & 2.881441 \\
\hline C & 0.210273 & -0.069210 & -1.139955 & H & 0.142134 & 5.964225 & -0.157966 \\
\hline C & 0.248384 & 0.898834 & -2.058534 & H & 1.589068 & 6.573749 & 0.677101 \\
\hline C & 3.131811 & -1.307765 & 0.791398 & $\mathrm{H}$ & 0.194186 & 6.015895 & 1.619762 \\
\hline C & 1.929132 & -0.736940 & 0.470628 & H & 2.969154 & 4.753346 & -0.669523 \\
\hline $\mathrm{N}$ & 1.482047 & -0.701897 & -0.810612 & $\mathrm{H}$ & 2.500082 & 3.051914 & -0.477777 \\
\hline C & 2.225874 & -1.262657 & -1.795976 & $\mathrm{H}$ & 1.459287 & 4.165878 & -1.399872 \\
\hline C & 3.436787 & -1.846053 & -1.547445 & $\mathrm{H}$ & -1.915825 & -4.574598 & -0.690657 \\
\hline C & 3.949473 & -1.889910 & -0.218408 & H & -3.655774 & -5.792916 & 0.605789 \\
\hline$N$ & 5.130807 & -2.455118 & 0.064587 & H & -4.914686 & -4.612208 & 2.394254 \\
\hline C & 5.927670 & -3.059459 & -0.997014 & $\mathrm{H}$ & -4.435514 & -2.221947 & 2.870607 \\
\hline C & 5.612057 & -2.494996 & 1.441176 & $\mathrm{H}$ & -2.730295 & -1.013241 & 1.566341 \\
\hline 0 & 0.371124 & 3.436089 & 1.045260 & $\mathrm{H}$ & -0.939678 & 1.508702 & 1.329508 \\
\hline C & 1.390100 & 4.434348 & 0.758376 & 0 & -0.441719 & 0.125565 & 2.121492 \\
\hline C & 2.334144 & 4.307011 & 1.948848 & H & -0.956709 & -0.264373 & 2.836679 \\
\hline C & 0.782946 & 5.833929 & 0.714651 & TS9 & & & \\
\hline C & 2.118576 & 4.077470 & -0.534510 & C & -2.468587 & -3.391135 & -2.241505 \\
\hline C & -0.639973 & 3.210994 & 0.179116 & C & -3.522473 & -2.482211 & -2.341441 \\
\hline 0 & -0.873294 & 3.887049 & -0.811267 & C & -3.333477 & -1.157516 & -1.963211 \\
\hline C & -2.205035 & -2.721058 & 0.348142 & C & -2.098133 & -0.712082 & -1.475070 \\
\hline C & -2.476873 & -4.069572 & 0.089335 & C & -1.028871 & -1.625546 & -1.371379 \\
\hline C & -3.449207 & -4.748327 & 0.818738 & C & -1.237114 & -2.955954 & -1.761889 \\
\hline C & -4.156308 & -4.084905 & 1.822903 & $\mathrm{~N}$ & -1.935003 & 0.638906 & -1.084612 \\
\hline C & -3.888712 & -2.742080 & 2.089998 & C & 0.763123 & -1.842265 & 0.453695 \\
\hline C & -2.921888 & -2.060163 & 1.353450 & 0 & 1.943515 & -2.089111 & 0.688779 \\
\hline H & -5.124000 & 0.040240 & -2.483065 & C & 0.316070 & -1.249232 & -0.838003 \\
\hline $\mathrm{H}$ & -5.343720 & 2.379401 & -1.642456 & C & 1.175954 & -0.562021 & -1.644815 \\
\hline
\end{tabular}




\begin{tabular}{|c|c|c|c|c|c|c|c|}
\hline C & 0.956702 & -0.102802 & -2.998753 & $\mathrm{H}$ & -3.503182 & 3.658595 & 2.918096 \\
\hline C & 3.512309 & 1.220593 & 0.609646 & $\mathrm{H}$ & -2.021906 & 2.800142 & 2.453699 \\
\hline C & 2.372665 & 0.763499 & 0.010950 & $\mathrm{H}$ & -5.255684 & 4.213599 & 1.001431 \\
\hline N & 2.411961 & -0.072390 & -1.055438 & $\mathrm{H}$ & -4.847833 & 3.727008 & -0.655037 \\
\hline C & 3.607206 & -0.466098 & -1.557691 & $\mathrm{H}$ & -5.249047 & 2.490888 & 0.560983 \\
\hline C & 4.788979 & -0.059365 & -1.006554 & $\mathrm{H}$ & 0.858873 & -3.914272 & 2.135507 \\
\hline C & 4.788969 & 0.811635 & 0.123617 & $\mathrm{H}$ & -0.765104 & -4.529821 & 3.918197 \\
\hline $\mathrm{N}$ & 5.924928 & 1.227120 & 0.694136 & $\mathrm{H}$ & -2.782535 & -3.128825 & 4.288624 \\
\hline C & 7.214776 & 0.801742 & 0.160528 & H & -3.177032 & -1.123437 & 2.869162 \\
\hline C & 5.881939 & 2.080840 & 1.877164 & $\mathrm{H}$ & -1.581060 & -0.538972 & 1.084978 \\
\hline 0 & -2.538437 & 2.539394 & -0.124559 & 0 & -0.465032 & 2.079621 & -2.622156 \\
\hline C & -3.280192 & 3.385936 & 0.794322 & H & 0.003459 & 2.800535 & -2.183112 \\
\hline C & -2.626673 & 4.750295 & 0.599944 & $\mathrm{H}$ & 0.348891 & 1.020111 & -2.863830 \\
\hline C & -3.089140 & 2.911642 & 2.233062 & TS10 & & & \\
\hline C & -4.753418 & 3.449016 & 0.399879 & C & 3.848558 & -3.200403 & -1.742891 \\
\hline C & -2.815632 & 1.218281 & -0.232237 & C & 4.464243 & -1.964346 & -1.939050 \\
\hline 0 & -3.707357 & 0.653048 & 0.391019 & C & 3.916121 & -0.783043 & -1.431049 \\
\hline C & -0.263850 & -2.200620 & 1.487979 & C & 2.720558 & -0.876807 & -0.716394 \\
\hline C & -0.032362 & -3.316170 & 2.300669 & C & 2.100479 & -2.110879 & -0.512105 \\
\hline C & -0.940354 & -3.654161 & 3.300431 & C & 2.653818 & -3.274993 & -1.022550 \\
\hline C & -2.074693 & -2.866063 & 3.507955 & $\mathrm{~N}$ & 1.963993 & 0.144599 & -0.102967 \\
\hline c & -2.299133 & -1.742431 & 2.712237 & C & -0.406431 & -2.472327 & -0.366617 \\
\hline C & -1.399935 & -1.414247 & 1.699605 & 0 & -0.394390 & -2.823752 & -1.530820 \\
\hline $\mathrm{H}$ & -2.604236 & -4.427985 & -2.533658 & C & 0.862997 & -1.955577 & 0.324204 \\
\hline $\mathrm{H}$ & -4.490340 & -2.803066 & -2.715295 & c & 0.848842 & -0.418400 & 0.702357 \\
\hline H & -4.148931 & -0.444630 & -2.033593 & C & 1.074710 & -0.246243 & 2.171566 \\
\hline $\mathrm{H}$ & -0.410172 & -3.657461 & -1.676694 & C & -2.588782 & 1.161001 & 0.515864 \\
\hline $\mathrm{H}$ & -1.287441 & 1.310144 & -1.686562 & C & -1.402937 & 0.654560 & 0.977926 \\
\hline $\mathrm{H}$ & 0.287244 & -0.746903 & -3.571415 & $\mathrm{~N}$ & -0.429720 & 0.226721 & 0.146538 \\
\hline H & 1.884189 & 0.107306 & -3.534889 & c & -0.611338 & 0.336656 & -1.191908 \\
\hline $\mathrm{H}$ & 3.412243 & 1.897245 & 1.447275 & C & -1.765397 & 0.830683 & -1.734183 \\
\hline H & 1.382645 & 1.048616 & 0.350639 & C & -2.832807 & 1.245418 & -0.884107 \\
\hline $\mathrm{H}$ & 3.566506 & -1.138758 & -2.406727 & $\mathrm{~N}$ & -3.997742 & 1.684862 & -1.377428 \\
\hline $\mathrm{H}$ & 5.708519 & -0.424516 & -1.443245 & C & -4.206085 & 1.750407 & -2.820283 \\
\hline $\mathrm{H}$ & 7.307695 & 1.079361 & -0.893796 & c & -5.063147 & 2.104769 & -0.473565 \\
\hline H & 8.005494 & 1.298288 & 0.719179 & 0 & 1.386383 & 2.215176 & 0.497946 \\
\hline $\mathrm{H}$ & 7.341223 & -0.281812 & 0.258599 & C & 1.563187 & 3.655227 & 0.688980 \\
\hline $\mathrm{H}$ & 5.410727 & 3.042349 & 1.648249 & C & 0.303863 & 4.037551 & 1.456940 \\
\hline $\mathrm{H}$ & 5.327807 & 1.594164 & 2.685894 & C & 1.602393 & 4.363223 & -0.660617 \\
\hline H & 6.900524 & 2.262075 & 2.213703 & C & 2.808024 & 3.921086 & 1.527281 \\
\hline $\mathrm{H}$ & -2.722380 & 5.074905 & -0.440662 & c & 2.316857 & 1.475689 & -0.113084 \\
\hline $\mathrm{H}$ & -3.109216 & 5.491116 & 1.244072 & 0 & 3.322774 & 1.903940 & -0.648630 \\
\hline $\mathrm{H}$ & -1.563098 & 4.705444 & 0.854533 & C & -1.682816 & -2.491238 & 0.416421 \\
\hline H & -3.589497 & 1.958154 & 2.407631 & C & -1.711704 & -2.598150 & 1.811581 \\
\hline
\end{tabular}




\begin{tabular}{|c|c|c|c|c|c|c|c|}
\hline C & -2.930079 & -2.556223 & 2.488155 & C & 2.107446 & -0.389530 & 1.017759 \\
\hline C & -4.119566 & -2.391317 & 1.778691 & C & 2.501732 & 1.403952 & -0.694983 \\
\hline $\mathrm{C}$ & -4.095441 & -2.291105 & 0.385717 & C & 1.565496 & 2.274209 & -0.233398 \\
\hline C & -2.882367 & -2.349881 & -0.293309 & c & 1.309257 & 3.513363 & 0.177165 \\
\hline $\mathrm{H}$ & 4.298119 & -4.102827 & -2.144734 & C & -1.579001 & -0.285882 & -1.133504 \\
\hline $\mathrm{H}$ & 5.395679 & -1.909668 & -2.494815 & C & -0.419217 & 0.461254 & -1.112470 \\
\hline $\mathrm{H}$ & 4.404888 & 0.168705 & -1.580225 & $\mathrm{~N}$ & -0.172272 & 1.395532 & -0.192867 \\
\hline $\mathrm{H}$ & 2.164465 & -4.230479 & -0.856743 & C & -1.074734 & 1.607971 & 0.768217 \\
\hline $\mathrm{H}$ & 0.982046 & -2.501624 & 1.265645 & C & -2.266419 & 0.915405 & 0.846609 \\
\hline $\mathrm{H}$ & 1.062022 & 0.807849 & 2.462945 & C & -2.561971 & -0.073189 & -0.130202 \\
\hline $\mathrm{H}$ & 0.316270 & -0.795105 & 2.740937 & $\mathrm{~N}$ & -3.714972 & -0.779681 & -0.101227 \\
\hline $\mathrm{H}$ & -3.323704 & 1.479355 & 1.243136 & C & -4.672813 & -0.566413 & 0.972515 \\
\hline $\mathrm{H}$ & -1.194031 & 0.570184 & 2.036423 & C & -3.975169 & -1.790591 & -1.114531 \\
\hline $\mathrm{H}$ & 0.208798 & 0.005702 & -1.819771 & $\mathrm{H}$ & 1.828238 & -2.004085 & 2.403642 \\
\hline $\mathrm{H}$ & -1.841483 & 0.885457 & -2.811915 & $\mathrm{H}$ & 3.306978 & -3.577688 & 1.162645 \\
\hline $\mathrm{H}$ & -4.089174 & 0.761293 & -3.274981 & $\mathrm{H}$ & 4.426691 & -2.802650 & -0.925203 \\
\hline $\mathrm{H}$ & -5.217339 & 2.103411 & -3.011980 & H & 1.474897 & 0.289624 & 1.583519 \\
\hline $\mathrm{H}$ & -3.498656 & 2.443348 & -3.287369 & $\mathrm{H}$ & 3.080182 & 1.711347 & -1.562944 \\
\hline $\mathrm{H}$ & -5.356753 & 1.283388 & 0.188593 & H & 0.317728 & 3.953170 & 0.135343 \\
\hline $\mathrm{H}$ & -4.746009 & 2.957854 & 0.135460 & $\mathrm{H}$ & 2.127800 & 4.124992 & 0.545468 \\
\hline $\mathrm{H}$ & -5.927477 & 2.401230 & -1.064299 & H & -1.712180 & -1.028508 & -1.909506 \\
\hline $\mathrm{H}$ & 0.250570 & 3.490442 & 2.403522 & $\mathrm{H}$ & 0.367445 & 0.314755 & -1.852064 \\
\hline $\mathrm{H}$ & 0.312797 & 5.109649 & 1.672666 & H & -0.814513 & 2.362897 & 1.508645 \\
\hline $\mathrm{H}$ & -0.588502 & 3.806800 & 0.865795 & H & -2.950721 & 1.135392 & 1.655894 \\
\hline $\mathrm{H}$ & 2.511752 & 4.122648 & -1.212719 & H & -5.049811 & 0.462675 & 0.969099 \\
\hline $\mathrm{H}$ & 1.566427 & 5.444671 & -0.495955 & H & -5.514811 & -1.242259 & 0.831592 \\
\hline $\mathrm{H}$ & 0.731752 & 4.079213 & -1.261438 & $\mathrm{H}$ & -4.223830 & -0.772108 & 1.951271 \\
\hline $\mathrm{H}$ & 2.831279 & 4.979646 & 1.803973 & $\mathrm{H}$ & -3.961890 & -1.353265 & -2.119034 \\
\hline $\mathrm{H}$ & 2.780160 & 3.325335 & 2.445342 & H & -3.233160 & -2.596934 & -1.073571 \\
\hline $\mathrm{H}$ & 3.719819 & 3.683611 & 0.977323 & $\mathrm{H}$ & -4.961423 & -2.217703 & -0.940130 \\
\hline $\mathrm{H}$ & -0.794270 & -2.733050 & 2.375267 & $\mathrm{H}$ & 4.048894 & -0.516273 & -1.766957 \\
\hline $\mathrm{H}$ & -2.948297 & -2.652971 & 3.569221 & TS12 & & & \\
\hline $\mathrm{H}$ & -5.065723 & -2.348036 & 2.310004 & C & -3.719308 & 1.181085 & 0.513526 \\
\hline $\mathrm{H}$ & -5.021319 & -2.167671 & -0.168339 & C & -3.339861 & 0.000002 & 0.000001 \\
\hline $\mathrm{H}$ & -2.847720 & -2.270328 & -1.376018 & C & -3.719312 & -1.181070 & -0.513544 \\
\hline 0 & 3.355230 & -1.486344 & 2.614142 & C & 0.650273 & 1.194382 & -0.182034 \\
\hline $\mathrm{H}$ & 3.832808 & -1.554600 & 1.777309 & C & -0.728620 & 1.136302 & -0.172367 \\
\hline $\mathrm{H}$ & 2.260585 & -0.840896 & 2.399800 & $\mathrm{~N}$ & -1.406259 & -0.000016 & 0.000020 \\
\hline TS11 & & & & C & -0.728606 & -1.136327 & 0.172394 \\
\hline C & 2.314206 & -1.685340 & 1.485058 & C & 0.650288 & -1.194396 & 0.182034 \\
\hline C & 3.144689 & -2.569541 & 0.793820 & C & 1.397726 & -0.000003 & -0.000006 \\
\hline C & 3.770992 & -2.131519 & -0.376577 & $\mathrm{~N}$ & 2.750569 & 0.000004 & -0.000017 \\
\hline C & 3.559948 & -0.841027 & -0.851030 & c & 3.477860 & -1.246976 & 0.178705 \\
\hline C & 2.717923 & 0.064490 & -0.170957 & c & 3.477842 & 1.246999 & -0.178707 \\
\hline
\end{tabular}




\begin{tabular}{|c|c|c|c|c|c|c|c|}
\hline $\mathrm{H}$ & -4.623887 & 1.651729 & 0.142652 & H & 2.698333 & -3.064731 & 0.720950 \\
\hline $\mathrm{H}$ & -3.164807 & -1.679358 & -1.302506 & H & 4. 322455 & -3.343936 & 0.024838 \\
\hline $\mathrm{H}$ & -4.623932 & -1.651681 & -0.142729 & $\mathrm{H}$ & 4.137370 & -2.396990 & 1.531241 \\
\hline $\mathrm{H}$ & 1.137130 & 2.149130 & -0.333951 & TS-1-3 & & & \\
\hline $\mathrm{H}$ & -1.338123 & 2.028703 & -0.310961 & C & 3.100695 & -2.472364 & 2.356752 \\
\hline $\mathrm{H}$ & -1.338097 & -2.028735 & 0.310999 & c & 1.984200 & -3.260496 & 2.614951 \\
\hline $\mathrm{H}$ & 1.137156 & -2.149139 & 0.333942 & C & 0.794569 & -3.075865 & 1.898049 \\
\hline $\mathrm{H}$ & 3.231553 & -1.965592 & -0.611501 & C & 0.766000 & -2.090271 & 0.917298 \\
\hline $\mathrm{H}$ & 4.546190 & -1.041480 & 0.135306 & c & 1.894864 & -1.297299 & 0.623448 \\
\hline $\mathrm{H}$ & 3.252054 & -1.703084 & 1.149570 & C & 3.061061 & -1.487857 & 1.361734 \\
\hline $\mathrm{H}$ & 3.252002 & 1.703145 & -1.149546 & $\mathrm{~N}$ & -0.323345 & -1.683860 & 0.107869 \\
\hline $\mathrm{H}$ & 3.231550 & 1.965581 & 0.611536 & C & 2.182461 & 0.907043 & -0.758946 \\
\hline $\mathrm{H}$ & 4.546175 & 1.041512 & -0.135351 & 0 & 1.554573 & 1.915793 & -1.096613 \\
\hline $\mathrm{H}$ & -3.164833 & 1.679356 & 1.302520 & C & 1.554432 & -0.383634 & -0.494264 \\
\hline TS13 & & & & c & 0.038629 & -0.550386 & -0.769063 \\
\hline C & 2.868475 & 0.687506 & -0.660438 & c & 0.059015 & -0.888530 & -2.238954 \\
\hline C & 2.107433 & 1.773620 & -0.384702 & c & -2.355453 & 2.362733 & -0.761317 \\
\hline C & 1.986570 & 3.070699 & -0.184248 & C & -1.614883 & 1.277098 & -1.152530 \\
\hline C & -1.383826 & -0.583976 & -0.917358 & $\mathrm{~N}$ & -0.798511 & 0.625918 & -0.305339 \\
\hline C & -0.152922 & 0.040210 & -0.982230 & c & -0.701487 & 1.044269 & 0.976551 \\
\hline$N$ & 0.142148 & 1.156176 & -0.316526 & C & -1.404668 & 2.118719 & 1.448534 \\
\hline C & -0.791452 & 1.680314 & 0.481960 & C & -2.273138 & 2.837965 & 0.576598 \\
\hline C & -2.054774 & 1.139698 & 0.630111 & $N$ & -2.974626 & 3.901611 & 0.997025 \\
\hline C & -2.397930 & -0.033177 & -0.091484 & C & -2.872013 & 4.348526 & 2.381569 \\
\hline $\mathrm{N}$ & -3.623437 & -0.601785 & 0.009927 & C & -3.835814 & 4.621355 & 0.066358 \\
\hline C & -4.618171 & -0.031460 & 0.903995 & 0 & -2.408542 & -1.609929 & -0.678551 \\
\hline c & -3.912884 & -1.832898 & -0.707230 & c & -3.775669 & -2.084350 & -0.893493 \\
\hline $\mathrm{H}$ & 3.380615 & 0.612712 & -1.613722 & C & -4.318717 & -1.081546 & -1.904342 \\
\hline $\mathrm{H}$ & 1.043664 & 3.599251 & -0.263860 & c & -4.565673 & -2.012418 & 0.408500 \\
\hline $\mathrm{H}$ & 2.879560 & 3.638611 & 0.063371 & C & -3.758111 & -3.486977 & -1.490960 \\
\hline $\mathrm{H}$ & -1.548477 & -1.487028 & -1.491048 & C & -1.565726 & -2.268321 & 0.127092 \\
\hline $\mathrm{H}$ & 0.652973 & -0.372557 & -1.590057 & 0 & -1.851295 & -3.239791 & 0.805140 \\
\hline $\mathrm{H}$ & -0.506735 & 2.571194 & 1.038675 & c & 3.684003 & 0.967737 & -0.738335 \\
\hline $\mathrm{H}$ & -2.754707 & 1.616390 & 1.304350 & c & 4.464400 & -0.091772 & -1.213476 \\
\hline $\mathrm{H}$ & -4.847610 & 1.004118 & 0.628836 & c & 5.853931 & 0.016813 & -1.234128 \\
\hline $\mathrm{H}$ & -5.534429 & -0.615553 & 0.830883 & C & 6.471768 & 1.176634 & -0.764641 \\
\hline $\mathrm{H}$ & -4.277040 & -0.049062 & 1.946267 & C & 5.696464 & 2.236506 & -0.290014 \\
\hline $\mathrm{H}$ & -3.795946 & -1.696422 & -1.788190 & C & 4.307007 & 2.137237 & -0.290438 \\
\hline $\mathrm{H}$ & -3.254238 & -2.648391 & -0.384434 & H & 4.014027 & -2.618076 & 2.925679 \\
\hline $\mathrm{H}$ & -4.943519 & -2.122427 & -0.508319 & H & 2.023592 & -4.027492 & 3.382492 \\
\hline C & 2.879204 & -0.449200 & 0.234025 & $\mathrm{H}$ & -0.078321 & -3.679610 & 2.101263 \\
\hline 0 & 2.306387 & -0.533875 & 1.311047 & $\mathrm{H}$ & 3.940671 & -0.882447 & 1.174882 \\
\hline 0 & 3.617358 & -1.475649 & -0.262676 & $\mathrm{H}$ & 1.531936 & -1.035443 & -1.631896 \\
\hline $\mathrm{C}$ & 3.691409 & -2.636291 & 0.562506 & H & -0.836802 & -1.377242 & -2.634813 \\
\hline
\end{tabular}




\begin{tabular}{|c|c|c|c|c|c|c|c|}
\hline $\mathrm{H}$ & 0.300196 & 0.009434 & -2.819026 & $\mathrm{~N}$ & 3.837552 & -3.458592 & 0.629768 \\
\hline $\mathrm{H}$ & -2.994034 & 2.836119 & -1.494679 & C & 5.082018 & -3.738264 & -0.068845 \\
\hline $\mathrm{H}$ & -1.651147 & 0.885885 & -2.162001 & C & 3.512642 & -4.178466 & 1.851152 \\
\hline $\mathrm{H}$ & -0.032453 & 0.481272 & 1.618562 & 0 & 1.977094 & 2.070443 & 0.723484 \\
\hline $\mathrm{H}$ & -1.274773 & 2.402397 & 2.484067 & C & 3.258917 & 2.709293 & 0.441428 \\
\hline $\mathrm{H}$ & -1.845554 & 4.644297 & 2.622877 & C & 4.263350 & 1.639503 & 0.851839 \\
\hline $\mathrm{H}$ & -3.523502 & 5.209082 & 2.520974 & C & 3.437917 & 3.962571 & 1.292605 \\
\hline $\mathrm{H}$ & -3.186751 & 3.558394 & 3.071294 & C & 3.366077 & 2.997825 & -1.051658 \\
\hline $\mathrm{H}$ & -3.258111 & 5.007464 & -0.780026 & C & 0.815577 & 2.705223 & 0.486730 \\
\hline $\mathrm{H}$ & -4.632321 & 3.972307 & -0.313228 & 0 & 0.688198 & 3.871558 & 0.166619 \\
\hline $\mathrm{H}$ & -4.290780 & 5.461304 & 0.587429 & C & -3.198978 & -1.696404 & -0.228639 \\
\hline $\mathrm{H}$ & -3.716068 & -1.093476 & -2.818057 & C & -4.183049 & -2.598932 & -0.644340 \\
\hline $\mathrm{H}$ & -5.349718 & -1.339469 & -2.162478 & C & -5.130853 & -3.073632 & 0.259606 \\
\hline $\mathrm{H}$ & -4.306203 & -0.069977 & -1.486524 & C & -5.085498 & -2.668796 & 1.594515 \\
\hline $\mathrm{H}$ & -4.209069 & -2.745166 & 1.133658 & C & -4.092117 & -1.786183 & 2.020716 \\
\hline $\mathrm{H}$ & -5.621093 & -2.210916 & 0.196998 & C & -3.158142 & -1.293847 & 1.111139 \\
\hline $\mathrm{H}$ & -4.486027 & -1.009792 & 0.842192 & $\mathrm{H}$ & -5.331274 & 2.776853 & -0.228629 \\
\hline $\mathrm{H}$ & -4.773587 & -3.753825 & -1.799684 & $\mathrm{H}$ & -4.012321 & 4.325094 & 1.215644 \\
\hline $\mathrm{H}$ & -3.112920 & -3.512876 & -2.375192 & $\mathrm{H}$ & -1.603623 & 3.863931 & 1.628522 \\
\hline $\mathrm{H}$ & -3.406104 & -4.226425 & -0.770479 & $\mathrm{H}$ & -4.219389 & 0.843505 & -1.294973 \\
\hline $\mathrm{H}$ & 3.983007 & -0.998155 & -1.571920 & $\mathrm{H}$ & 0.061297 & 0.850349 & 0.678320 \\
\hline $\mathrm{H}$ & 6.453747 & -0.804174 & -1.615423 & $\mathrm{H}$ & 1.255553 & 1.190616 & -2.735519 \\
\hline $\mathrm{H}$ & 7.554820 & 1.256859 & -0.772925 & $\mathrm{H}$ & -0.388530 & 1.650150 & -3.486238 \\
\hline $\mathrm{H}$ & 6.175333 & 3.140570 & 0.074235 & $\mathrm{H}$ & 1.380334 & -2.858387 & 1.611173 \\
\hline $\mathrm{H}$ & 3.692617 & 2.961619 & 0.059869 & $\mathrm{H}$ & -0.183459 & -1.304070 & 0.539117 \\
\hline TS-L & & & & $\mathrm{H}$ & 2.392693 & -0.577360 & -2.596810 \\
\hline C & -4.275585 & 2.595997 & -0.050725 & $\mathrm{H}$ & 4.090098 & -2.094833 & -1.701447 \\
\hline C & -3.537477 & 3.463901 & 0.755782 & $\mathrm{H}$ & 5.656867 & -2.819590 & -0.230058 \\
\hline C & -2.187819 & 3.214836 & 0.984316 & $\mathrm{H}$ & 5.683015 & -4.414758 & 0.536807 \\
\hline C & -1.566600 & 2.110610 & 0.396930 & $\mathrm{H}$ & 4.898268 & -4.211643 & -1.041223 \\
\hline C & -2.287069 & 1.242661 & -0.446127 & $\mathrm{H}$ & 3.277535 & -3.483715 & 2.664648 \\
\hline C & -3.650877 & 1.503547 & -0.644551 & $\mathrm{H}$ & 2.657378 & -4.849845 & 1.705726 \\
\hline $\mathrm{N}$ & -0.214051 & 1.825066 & 0.695270 & $\mathrm{H}$ & 4.373855 & -4.774362 & 2.149959 \\
\hline C & -2.169545 & -1.247775 & -1.233357 & $\mathrm{H}$ & 4.087856 & 0.716708 & 0.289273 \\
\hline 0 & -1.774683 & -2.058120 & -2.072467 & $\mathrm{H}$ & 5.280062 & 1.987773 & 0.648458 \\
\hline C & -1.630863 & 0.112919 & -1.163371 & $\mathrm{H}$ & 4.175875 & 1.419982 & 1.920365 \\
\hline C & -0.500074 & 0.387054 & -1.864202 & $\mathrm{H}$ & 2.779042 & 4.768044 & 0.966805 \\
\hline C & 0.175370 & 1.102899 & -2.733635 & $\mathrm{H}$ & 4.476005 & 4.300438 & 1.213271 \\
\hline C & 1.673370 & -2.368489 & 0.691591 & $\mathrm{H}$ & 3.231990 & 3.736228 & 2.343854 \\
\hline C & 0.794653 & -1.488218 & 0.089833 & $\mathrm{H}$ & 4.358116 & 3.404451 & -1.271666 \\
\hline $\mathrm{N}$ & 1.052408 & -0.834475 & -1.043526 & $\mathrm{H}$ & 3.241691 & 2.070742 & -1.621840 \\
\hline C & 2.217118 & -1.084212 & -1.649996 & $\mathrm{H}$ & 2.614091 & 3.721442 & -1.373199 \\
\hline C & 3.173448 & -1.945611 & -1.145247 & $\mathrm{H}$ & -4.197771 & -2.919746 & -1.681785 \\
\hline $\mathrm{C}$ & 2.928783 & -2.618274 & 0.080236 & $\mathrm{H}$ & -5.901106 & -3.762048 & -0.075005 \\
\hline
\end{tabular}



$\begin{array}{llll}\text { H } & -5.820112 & -3.042467 & 2.301715\end{array}$
$\begin{array}{llll}\mathrm{H} & -4.046606 & -1.477353 & 3.060681\end{array}$
$\begin{array}{llll}\text { H } & -2.391814 & -0.601587 & 1.450032\end{array}$ 


\section{References}

1. Nicolaou, K. C.; Roecker, A. J.; Hughes, R.; Summeren, R. v.; Pfefferkorna, J. A.; Winssinger, N. Novel Strategies for the Solid Phase Synthesis of Substituted Indolines and Indoles. Bioorg. Med. Chem. 2003, 11, 465-476.

2. Bhaskar, G.; Saikumar, C.; Perumal, P. T. Indium(III) Bromide-Catalyzed Hydroarylation of Alkynes with Indoles. Tetrahedron Lett. 2010, 51, 3141-3145.

3. Sharma, P.; Liu, R. S. [3 + 2]-Annulations of N-Hydroxy Allenylamines with Nitrosoarenes: One-Pot Synthesis of Substituted Indole Products. Org. Lett. 2016, $18,412-415$.

4. Mennie, K. M.; Banik, S. M.; Reichert, E. C.; Jacobsen, E. N. Catalytic Diastereo- and Enantioselective Fluoroamination of Alkenes. J. Am. Chem. Soc. 2018, 140, 4797-4802.

5. Jana, S.; Verma, A.; Kadu, R.; Kumar, S. Visible-Light-Induced Oxidant and Metal-Free Dehydrogenative Cascade Trifluoromethylation and Oxidation of 1,6-Enynes with Water. Chem. Sci. 2017, 8, 6633-6644.

6. Frisch, M. J.; Trucks, G. W.; Schlegel, H. B.; Scuseria, G. E.; Robb, M. A.; Cheeseman, J. R.; Scalmani, G.; Barone, V.; Mennucci, B.; Petersson, G. A.; Nakatsuji, H.; Caricato, M.; Li, X.; Hratchian, H. P.; Izmaylov, A. F.; Bloino, J.; Zheng, G.; Sonnenberg, J. L.; Hada, M.; Ehara, M.; Toyota, K.; Fukuda, R.; Hasegawa, J.; Ishida, M.; Nakajima, T.; Honda, Y.; Kitao, O.; Nakai, H.; Vreven, T.; Montgomery, J. A.; Peralta, Jr., J. E.; Ogliaro, F.; Bearpark, M.; Heyd, J. J.; Brothers, E.; Kudin, K. N.; Staroverov, V. N.; Keith, T.; Kobayashi, R.; Normand, J.; Raghavachari, K.; Rendell, A.; Burant, J. C.; Iyengar, S. S.; Tomasi, J.; Cossi, M.; Rega, N.; Millam, J. M.; Klene, M.; Knox, J. E.; Cross, J. B.; Bakken, V.; Adamo, C.; Jaramillo, J.; Gomperts, R.; Stratmann, R. E.; Yazyev, O.; Austin, A. J.; Cammi, R.; Pomelli, C.; Ochterski, J. W.; Martin, R. L.; Morokuma, K.; Zakrzewski, V. G.; Voth, G. A.; Salvador ,P.; Dannenberg, J. J.; Dapprich, S.; Daniels, A. D.; Farkas, Ö.; Foresman, J. B.; Ortiz, J. V.; Cioslowski J.; Fox, D. J. Gaussian 09, Revision E.01, Gaussian, Inc., Wallingford, CT, 2013.

7. Zhao, Y.; Truhlar, D. G. Density Functionals with Broad Applicability in Chemistry. Acc. Chem. Res. 2008, 41, 157-167.

8. Marenich,A. V.; Cramer,C. J.; Truhlar, D. G. Universal Solvation Model Based on Solute Electron Density and on a Continuum Model of the Solvent Defined by the Bulk Dielectric Constant and Atomic Surface Tensions. J. Phys. Chem. B, 2009, 113, 6378-6396.

9. (a) Zhao, Y.; Truhlar, D. G. Computational Characterization and Modeling of Buckyball Tweezers: Density Functional Study of Concave-Convex $\pi \cdots \pi$ Interactions. Phys. Chem. Chem. Phys. 2008, 10, 2813-2818; (b) Ribeiro, R. F.; Marenich, A. V.; Cramer,C. J.; Truhlar, D. G. Use of Solution-Phase Vibrational Frequencies in Continuum Models for the Free Energy of Solvation. J. Phys. Chem. B, 2011, 115, 14556-14562. 


\section{NMR Spectra}

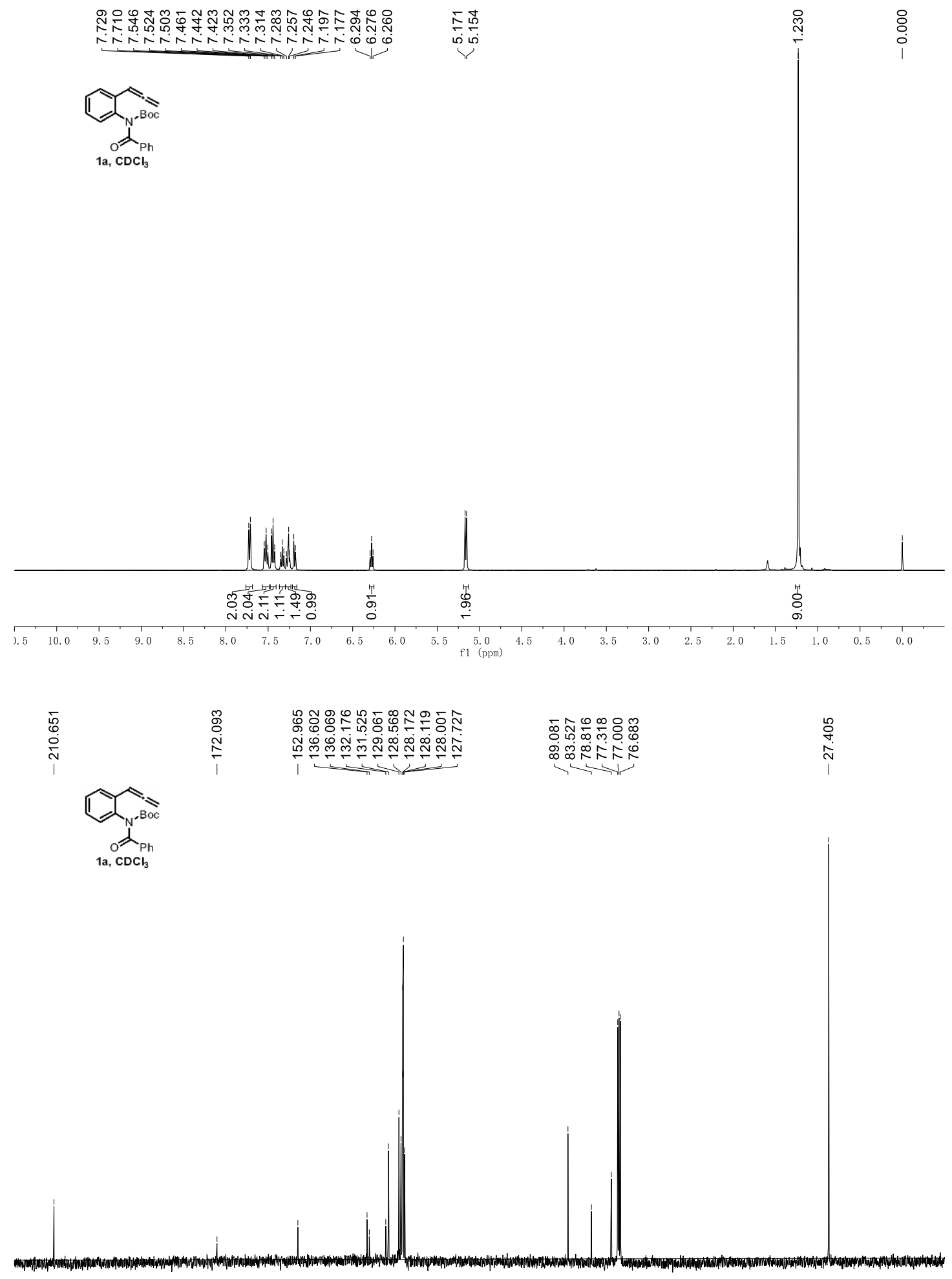

(10.0)

\begin{tabular}{lllllllllllll}
\hline 20 & 210 & 200 & 190 & 180 & 170 & 160 & 150 & 140 & 130 & 120 & 110 & 100
\end{tabular} 


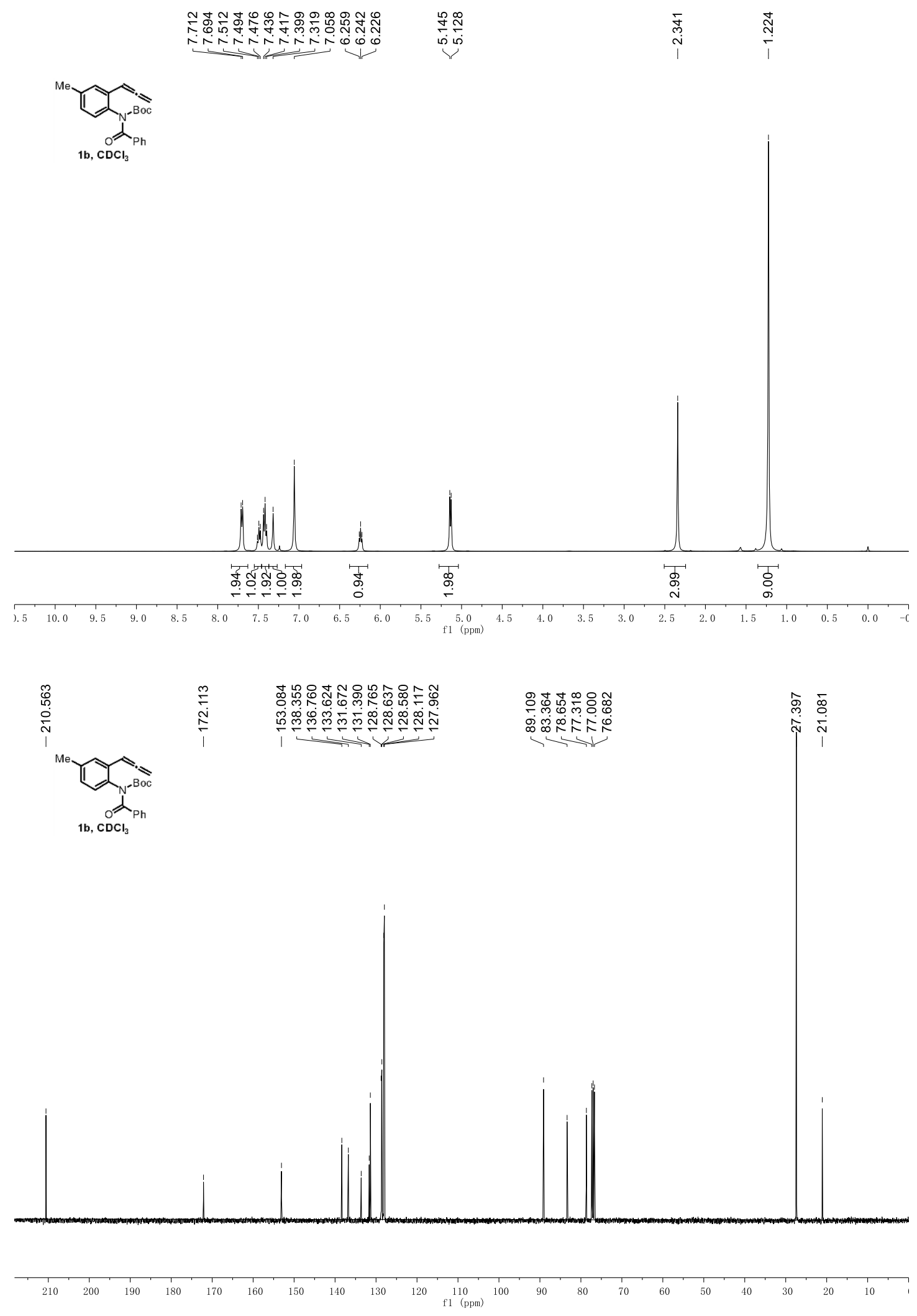




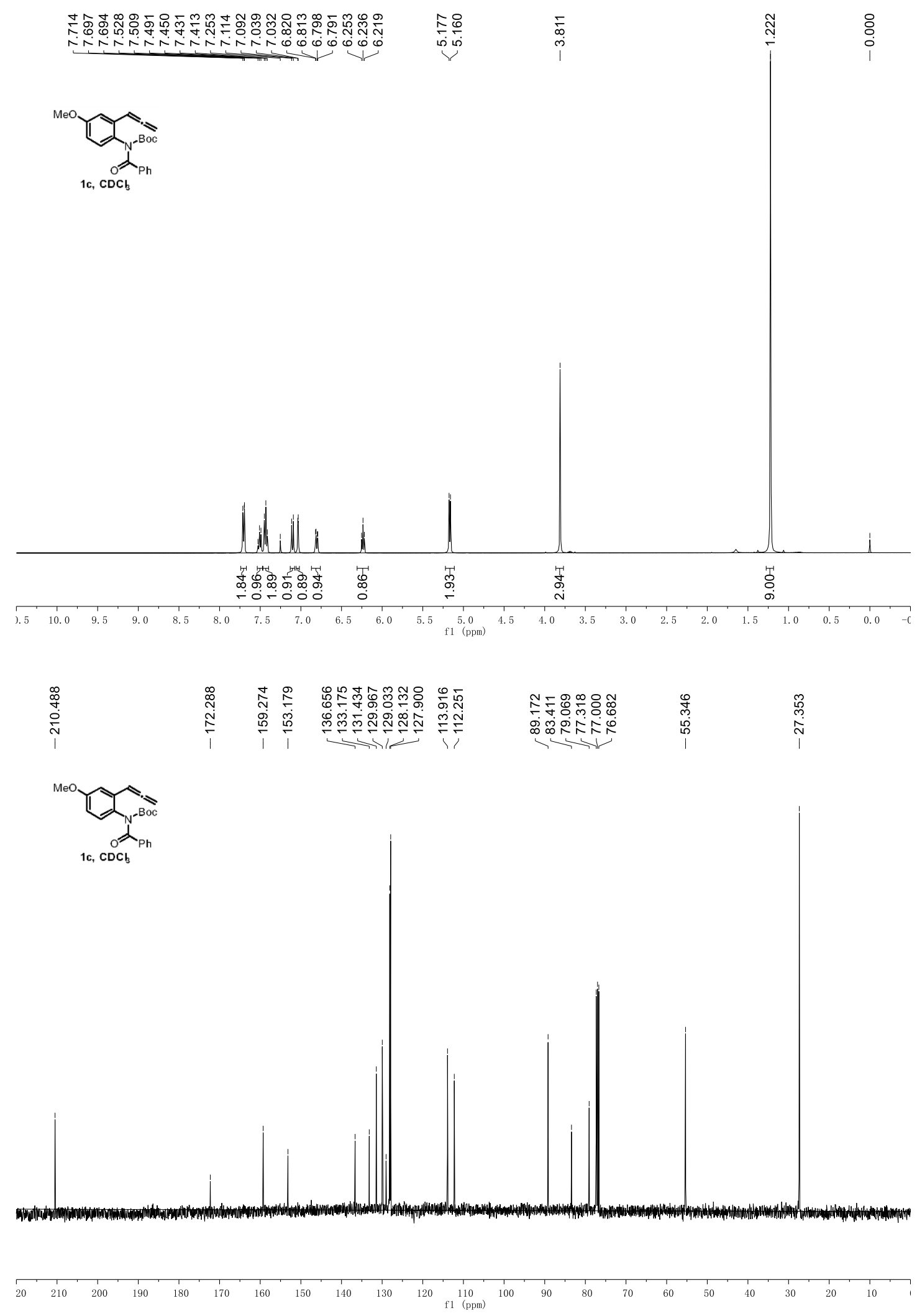



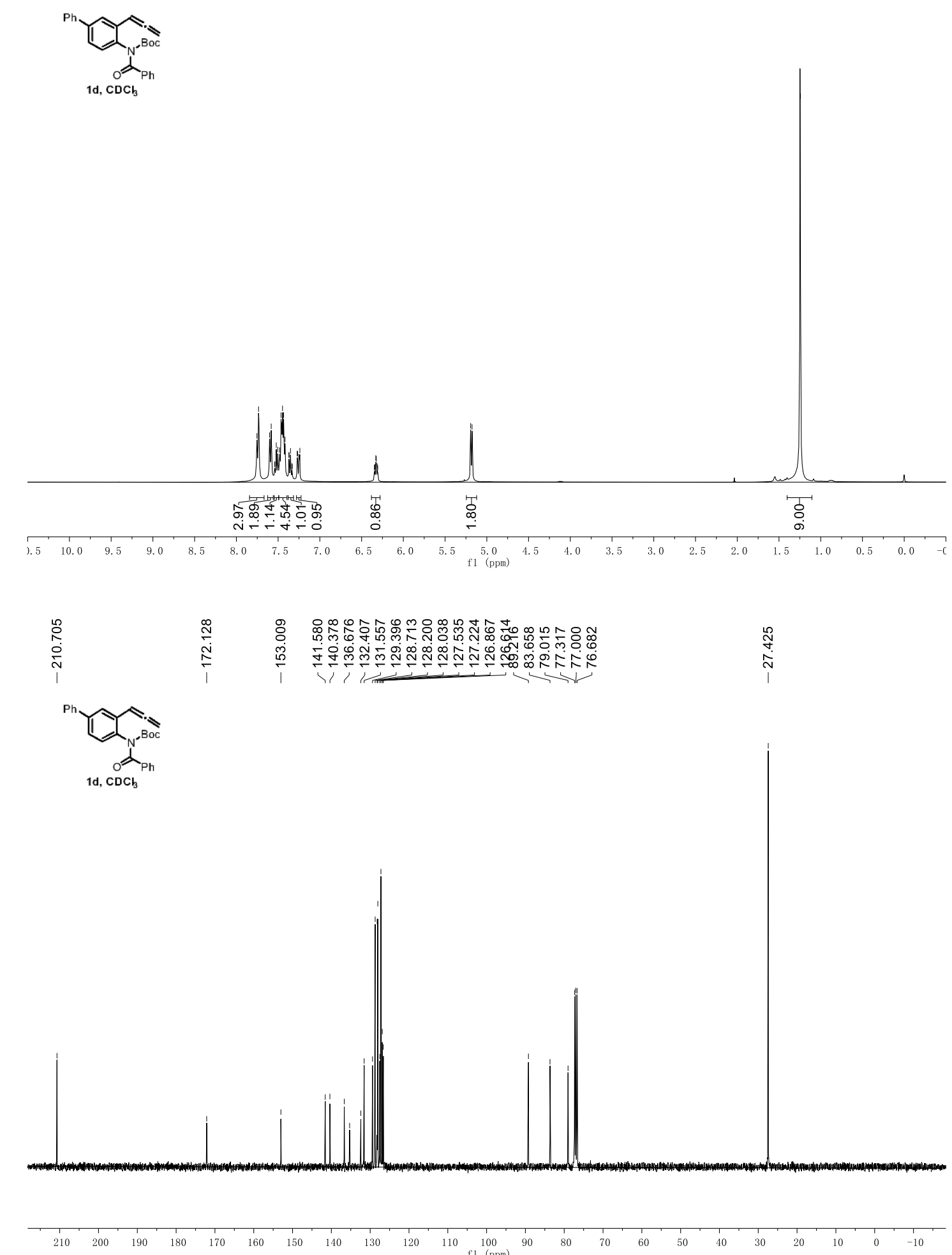

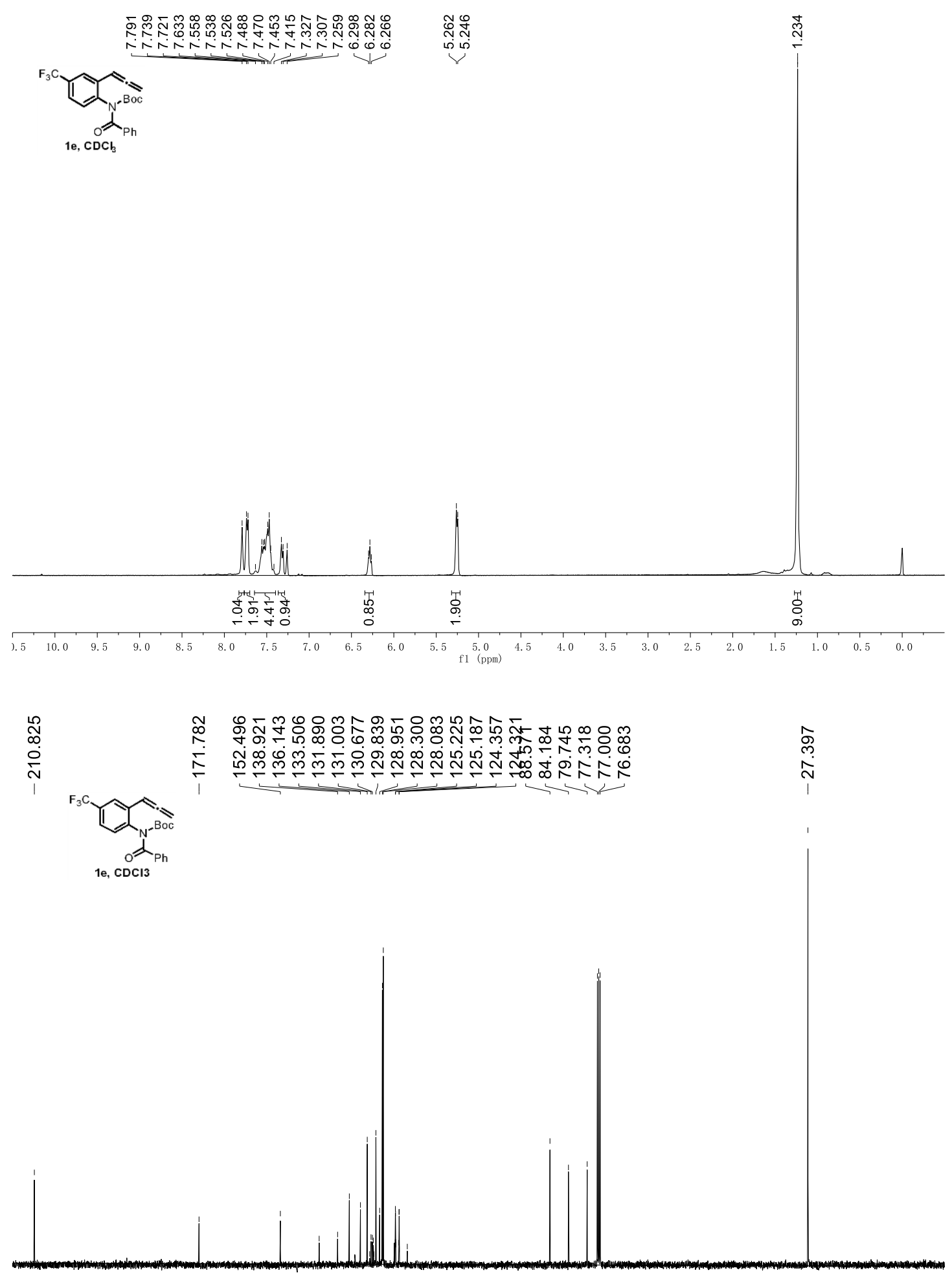

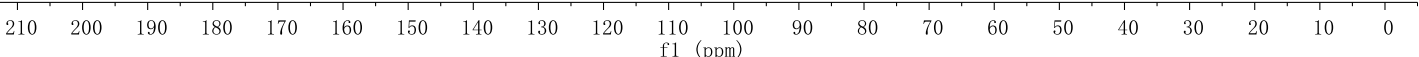



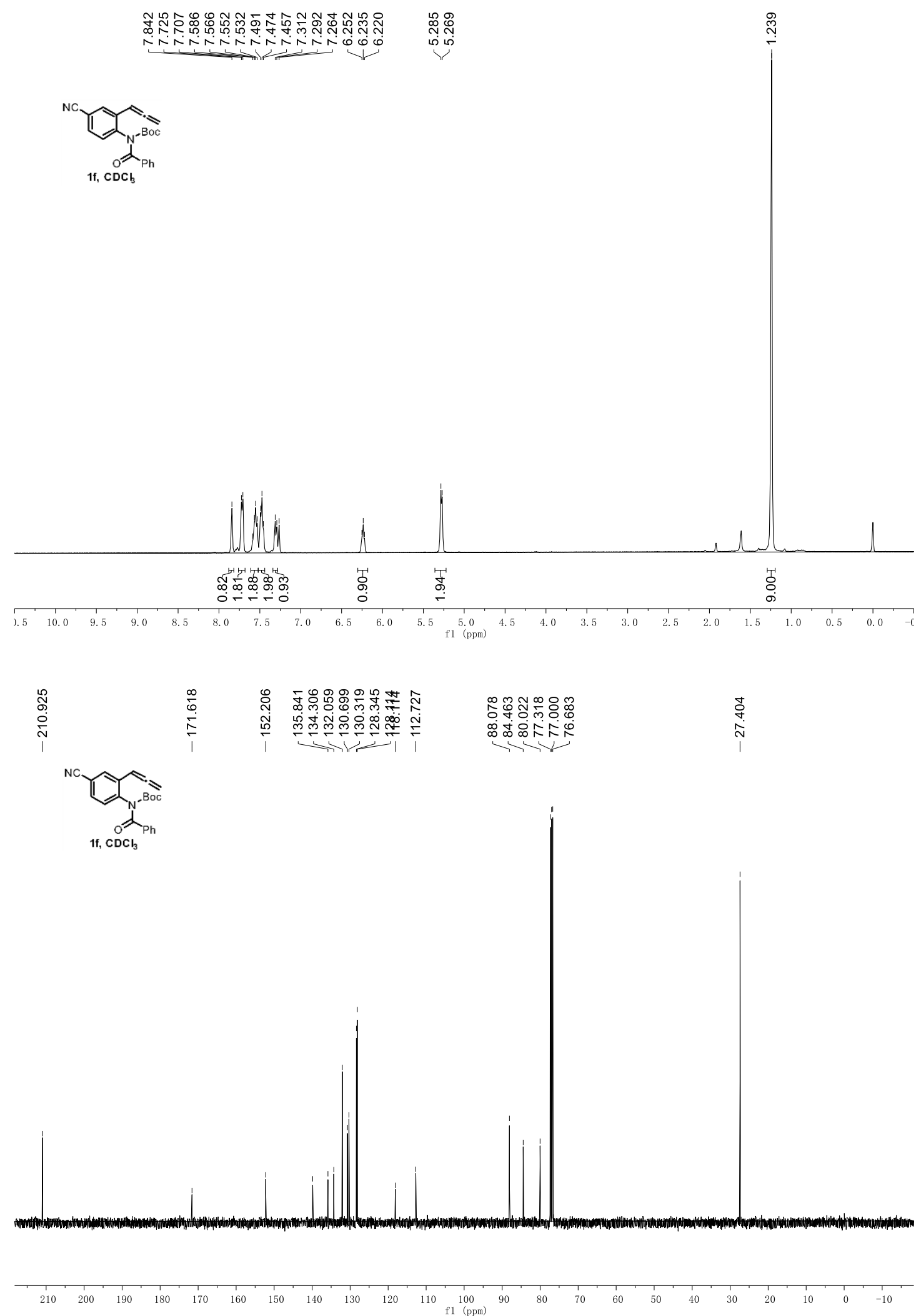

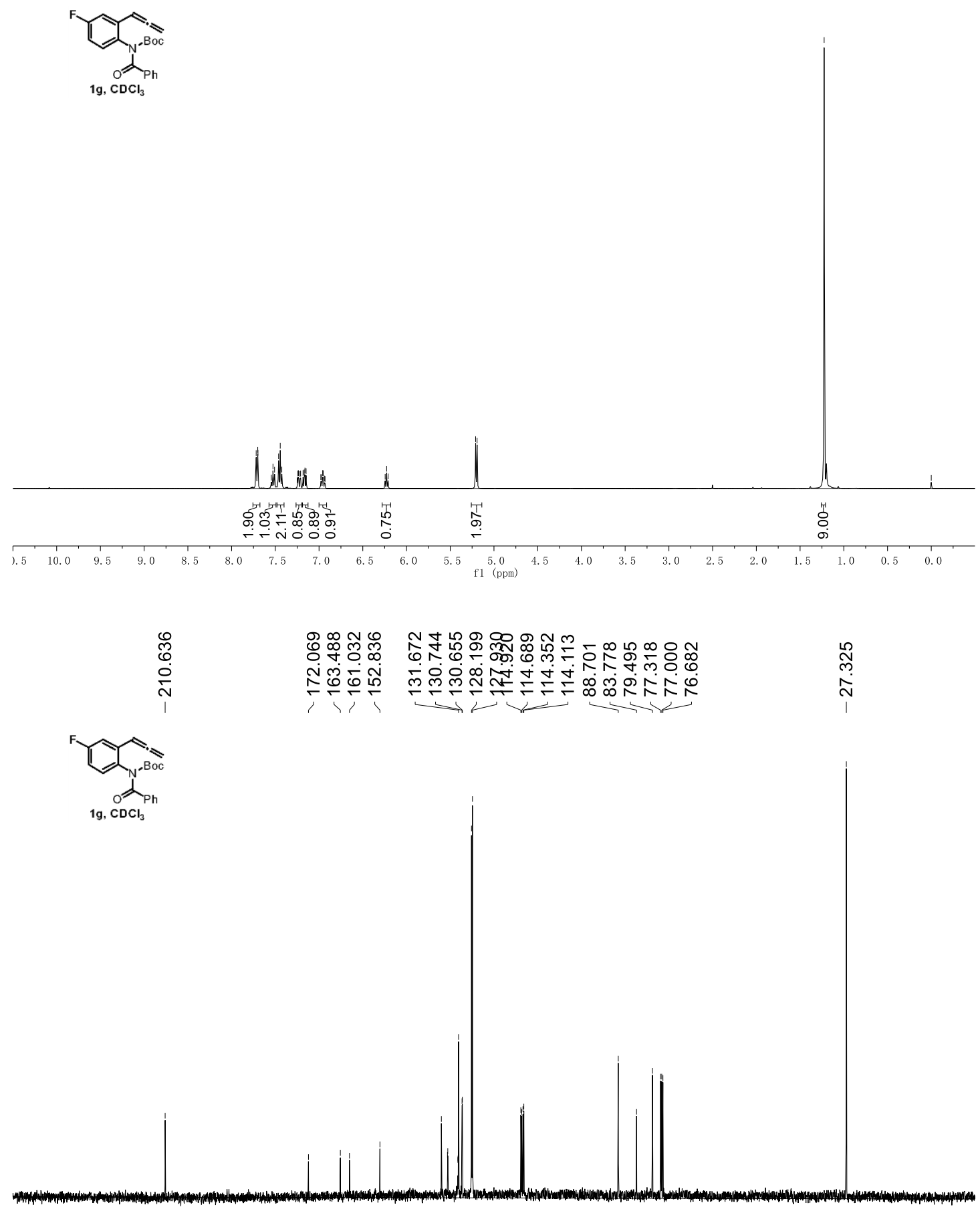

$\begin{array}{lllllllllllllllllllllllllllll}250 & 240 & 230 & 220 & 210 & 200 & 190 & 180 & 170 & 160 & 150 & 140 & 130 & 120 & 110 & 100 & 90 & 80 & 70 & 60 & 50 & 40 & 30 & 20 & 10 & 0\end{array}$ f1 (ppm) 


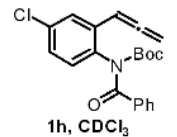

1h, $\mathrm{CDCl}_{3}$

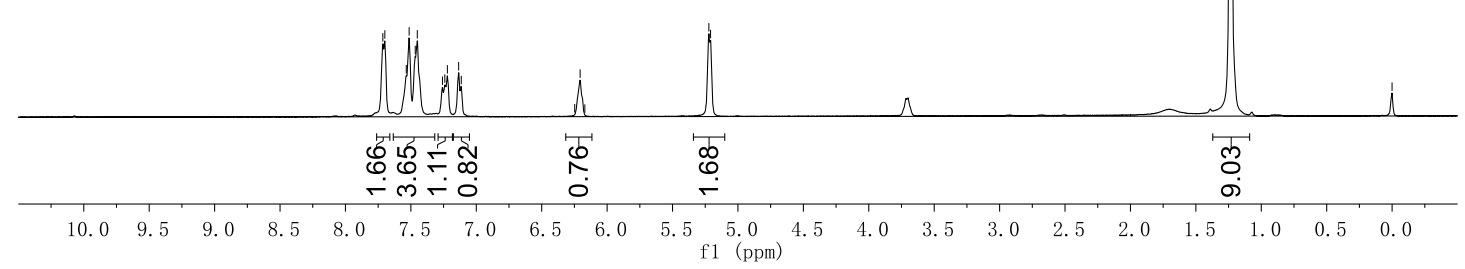

\begin{tabular}{|c|c|c|}
\hline 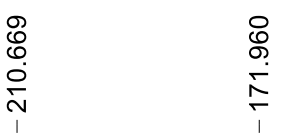 & 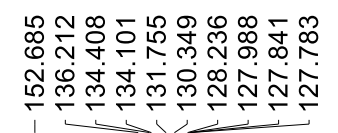 & 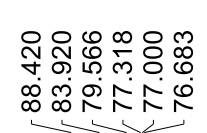 \\
\hline
\end{tabular}

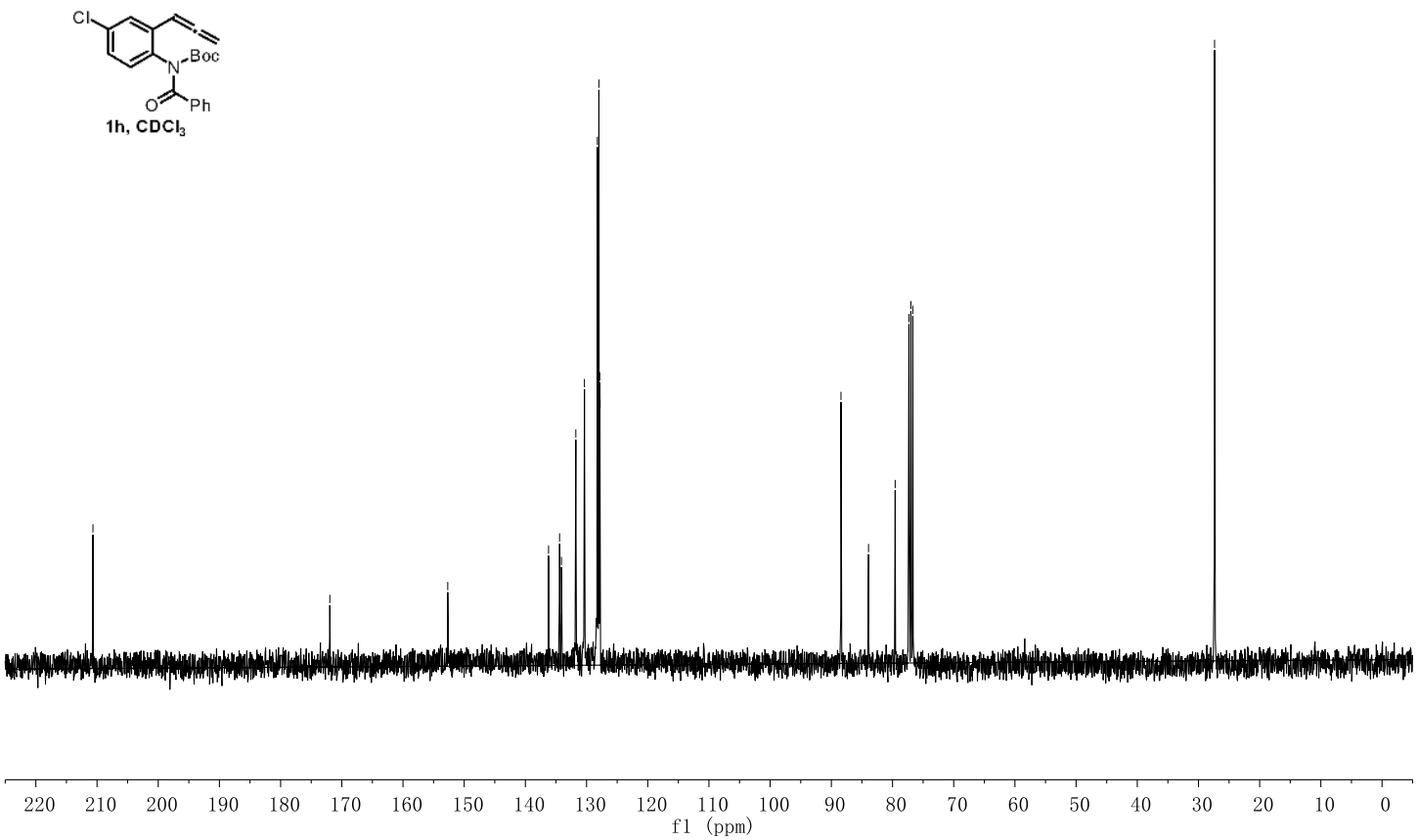



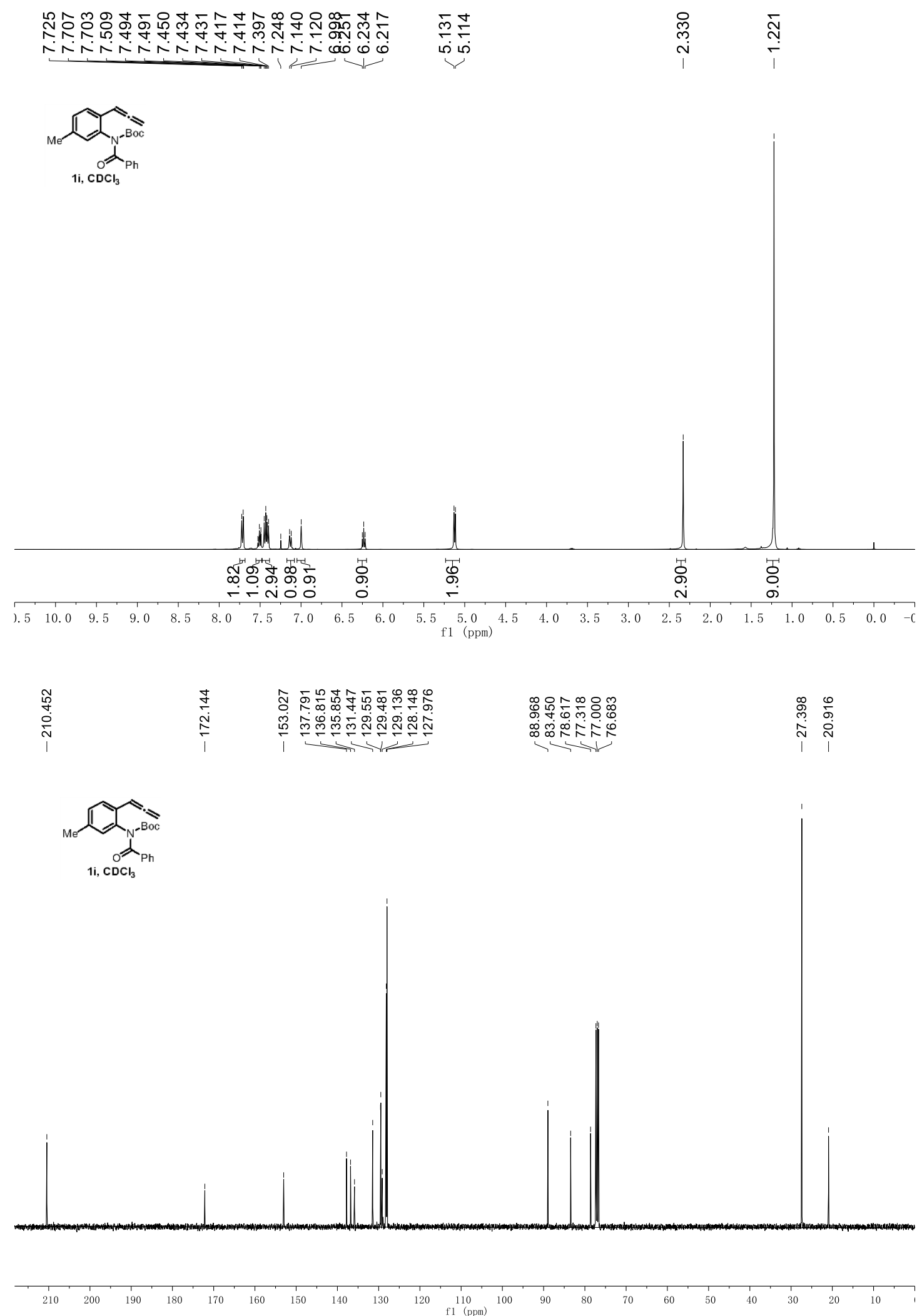


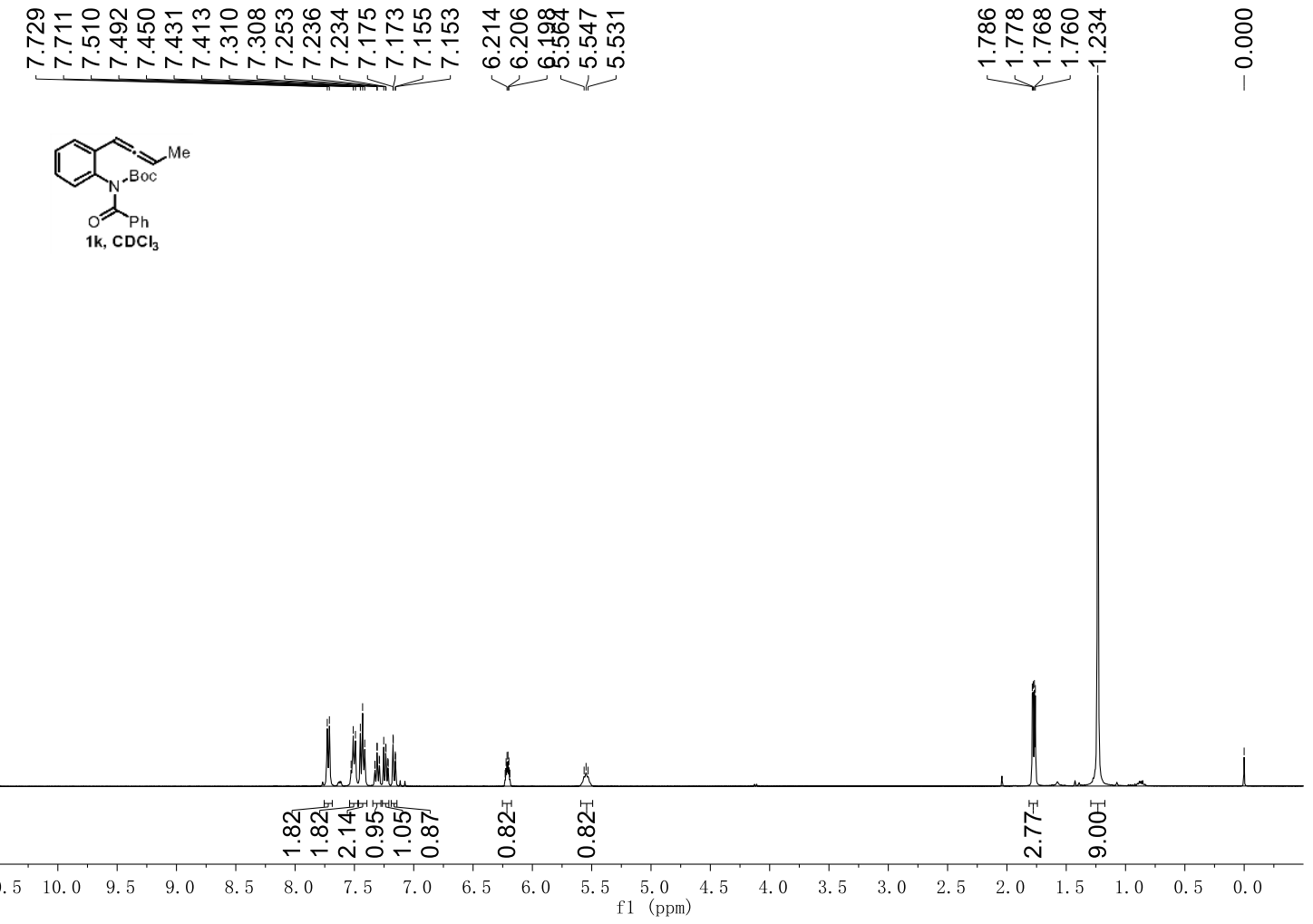

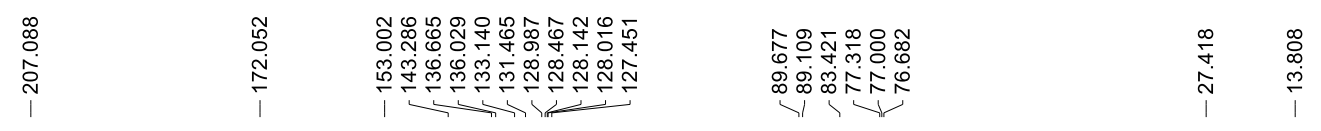

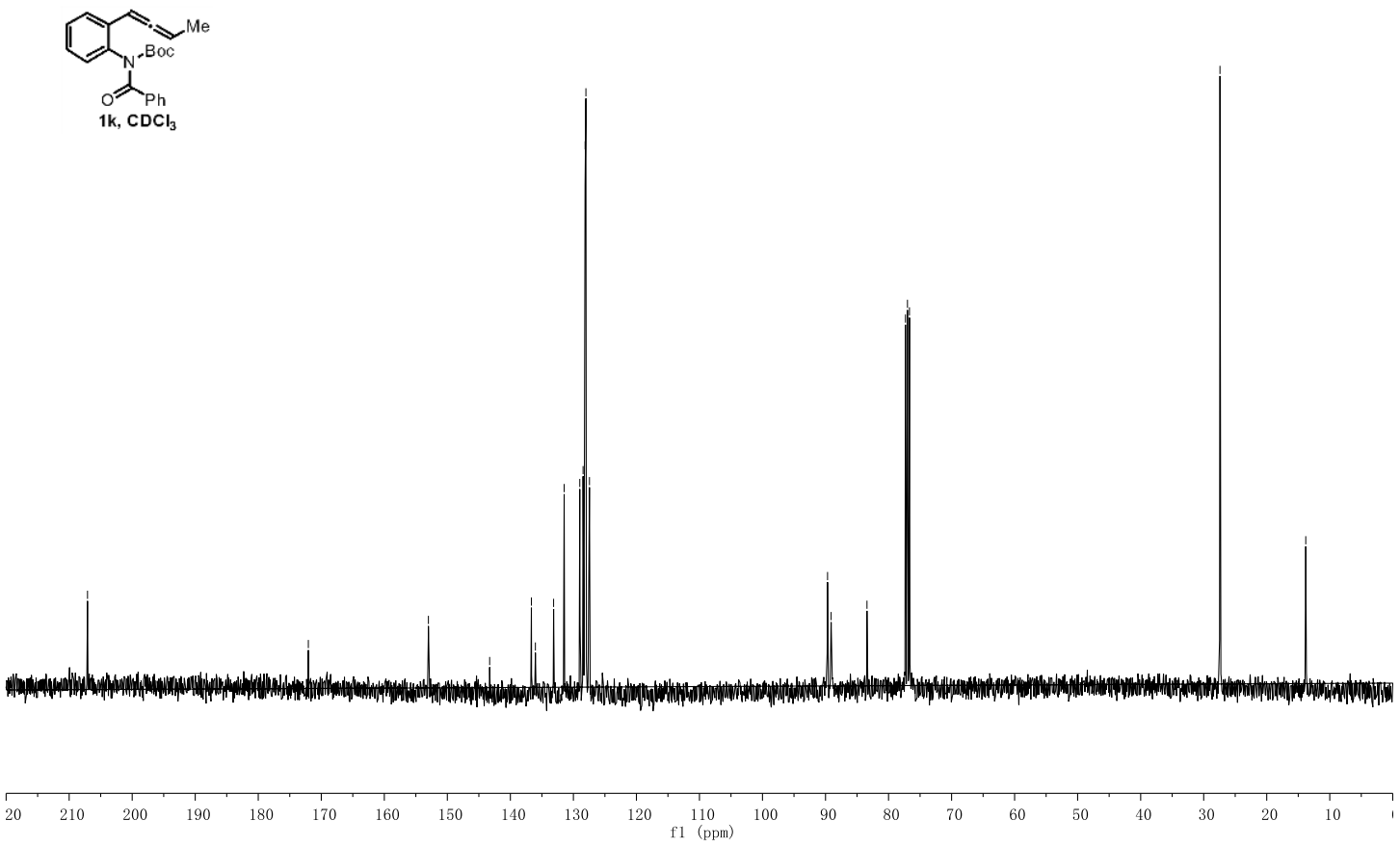



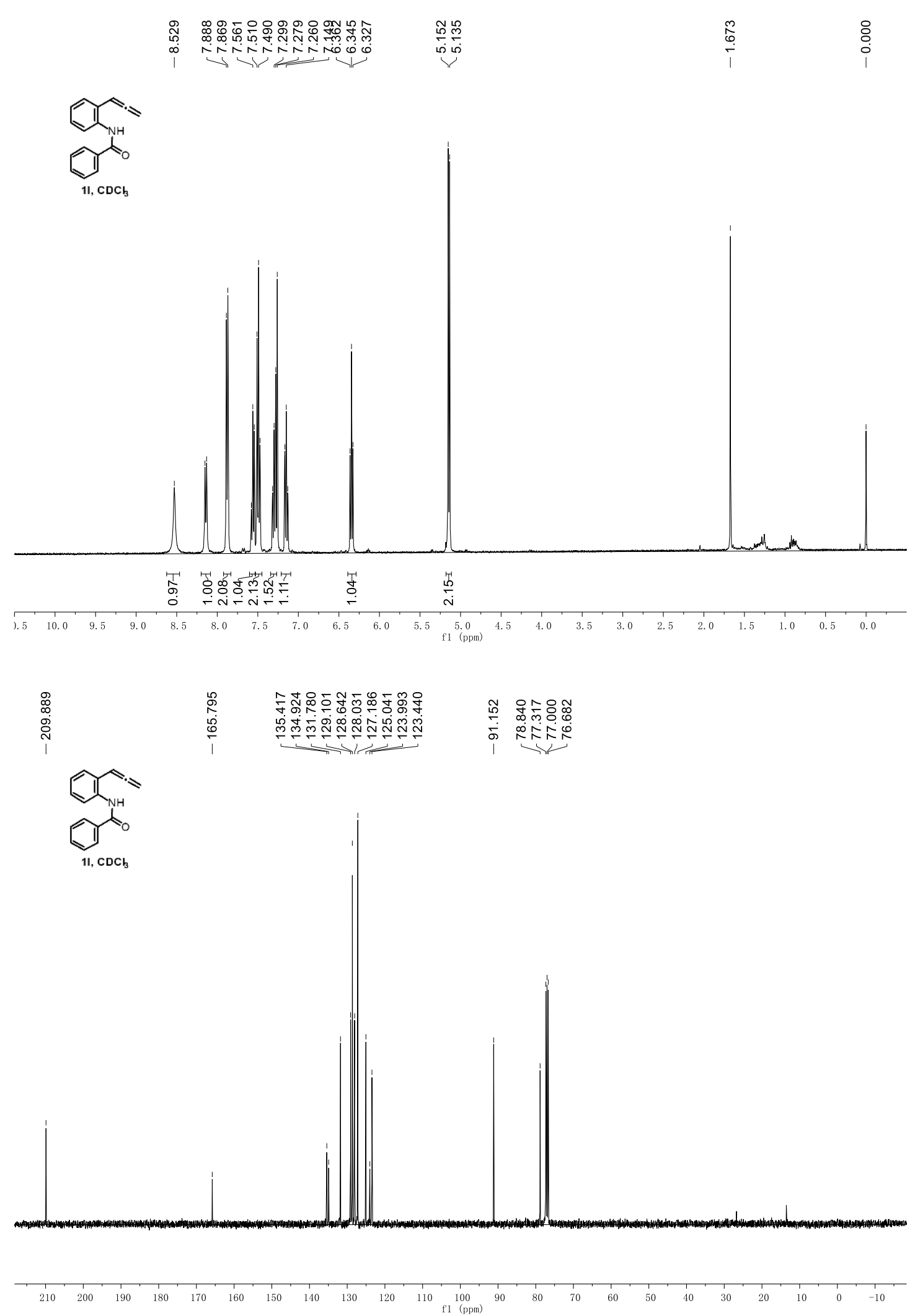


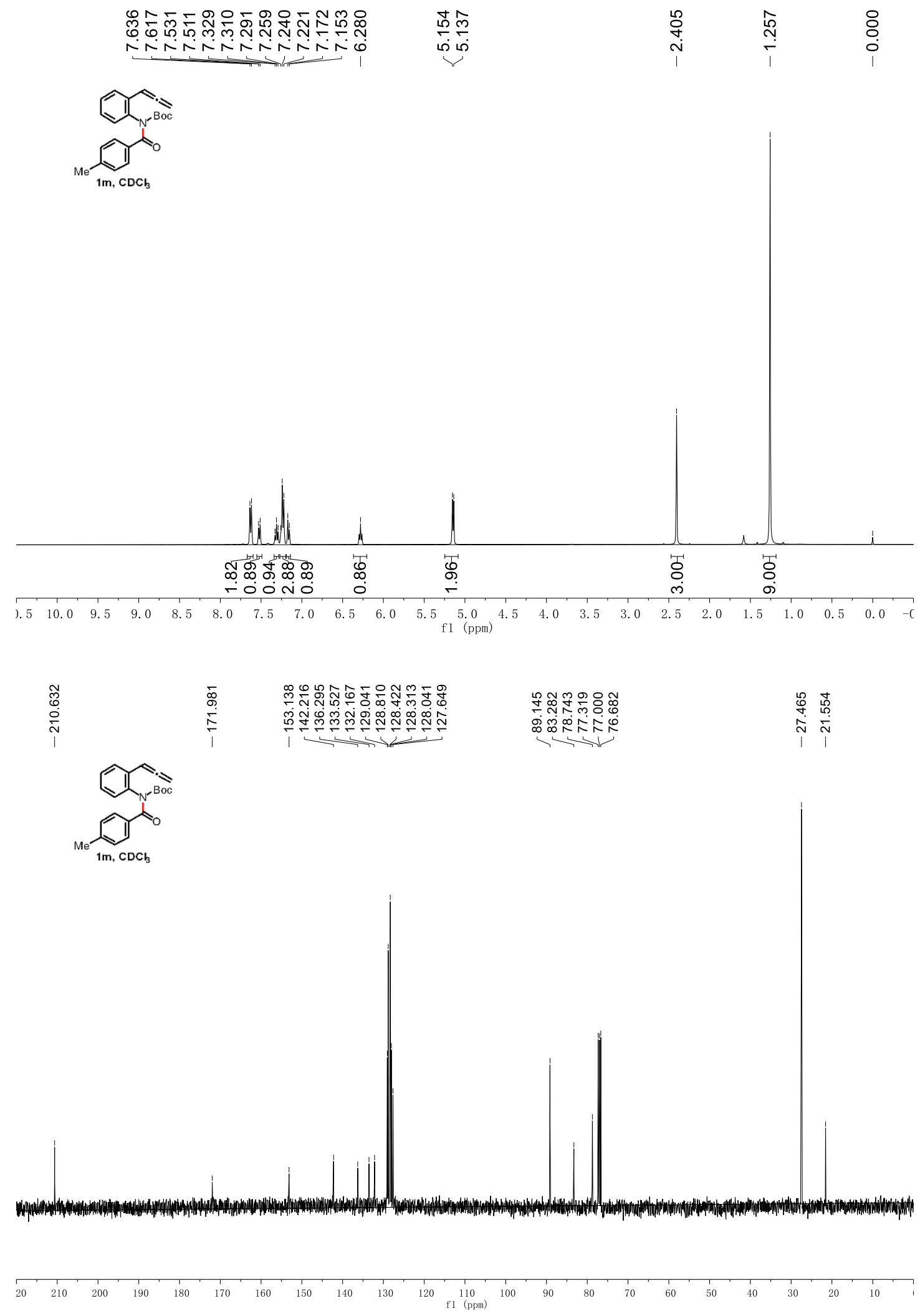



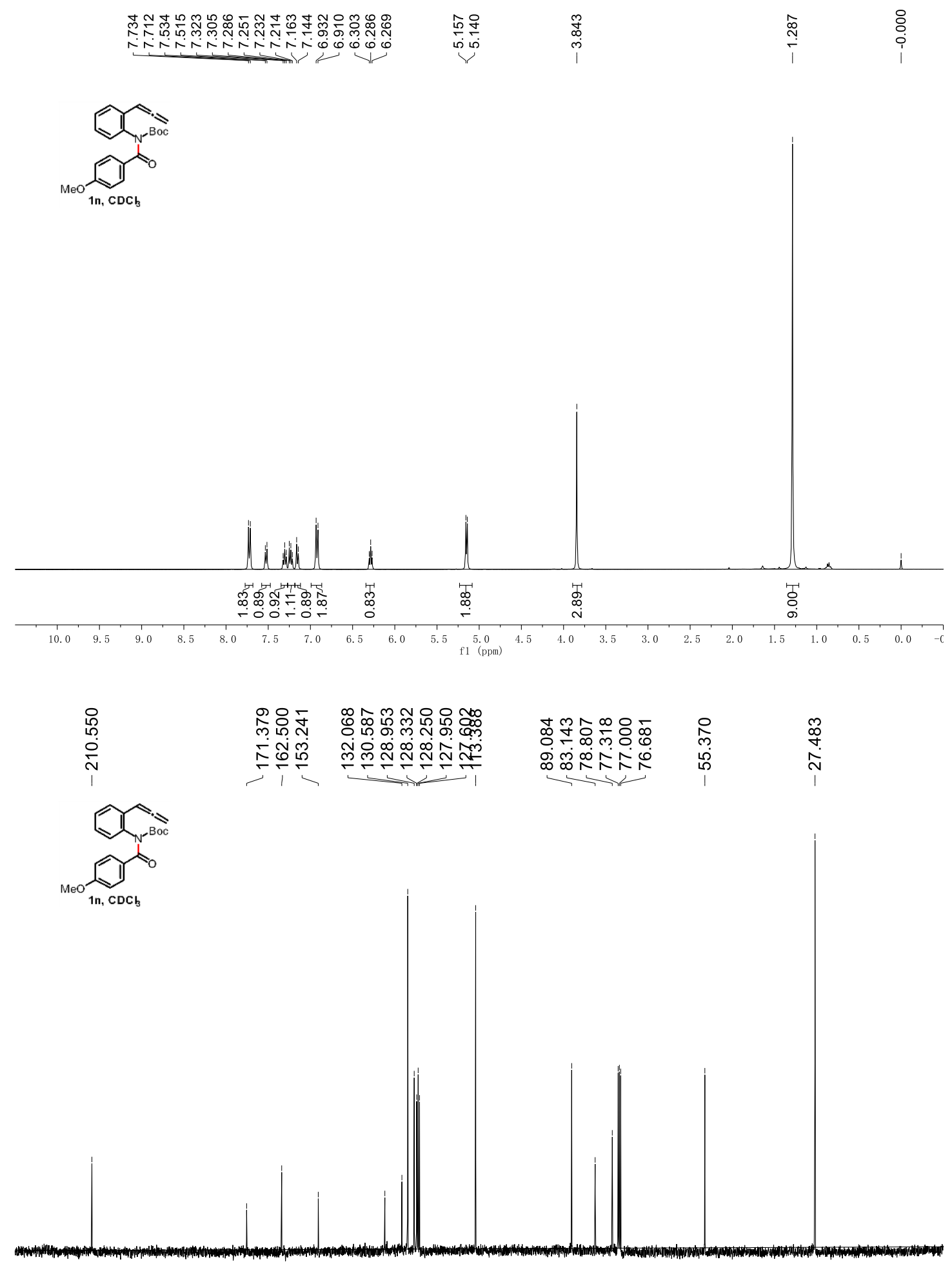

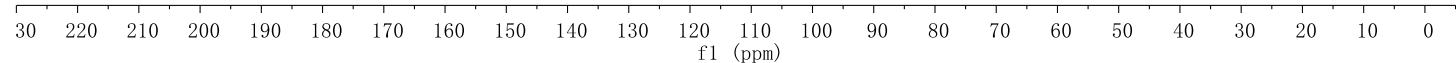




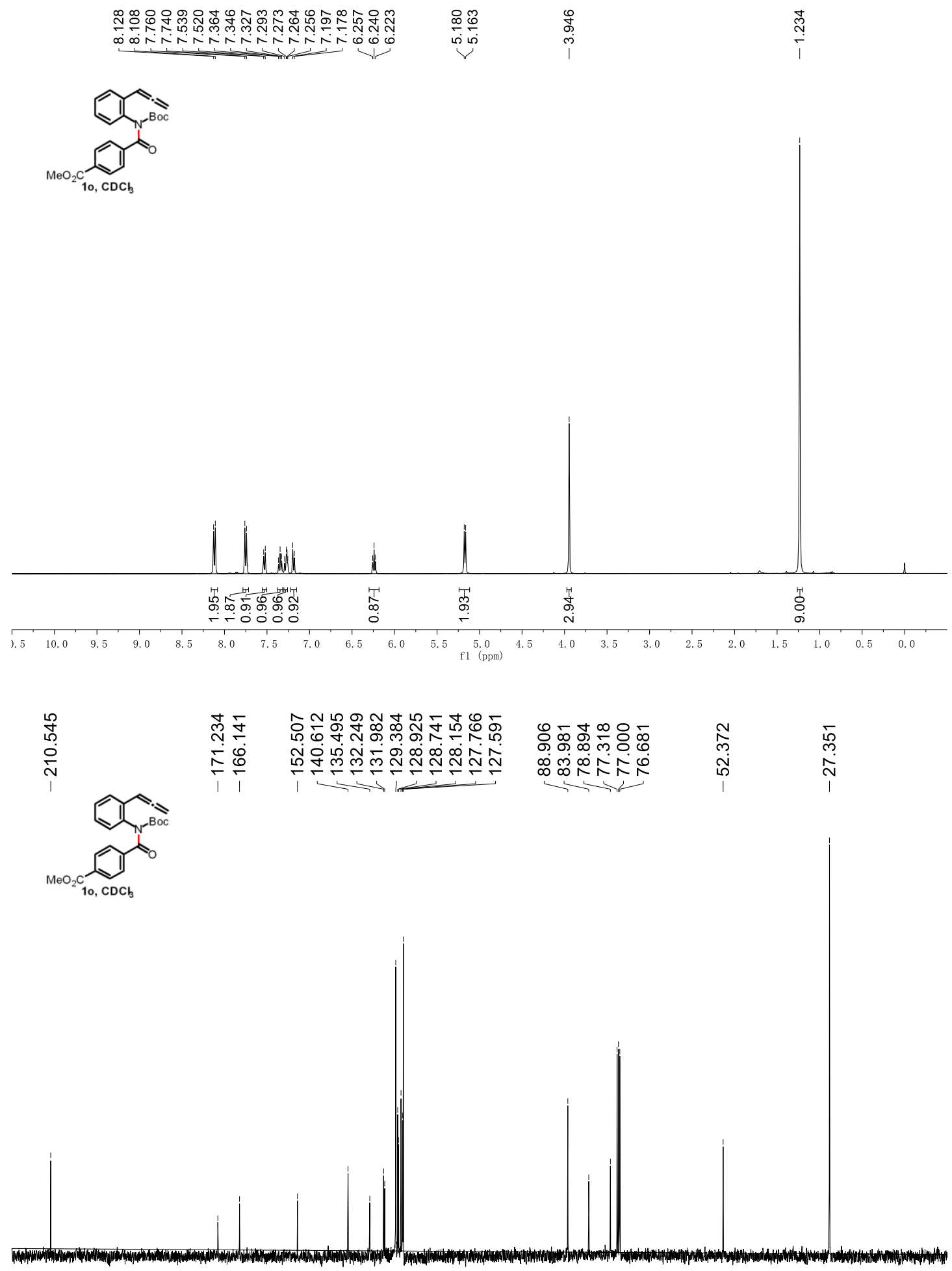

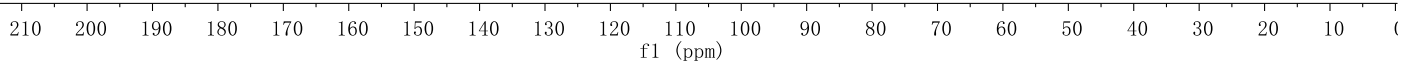




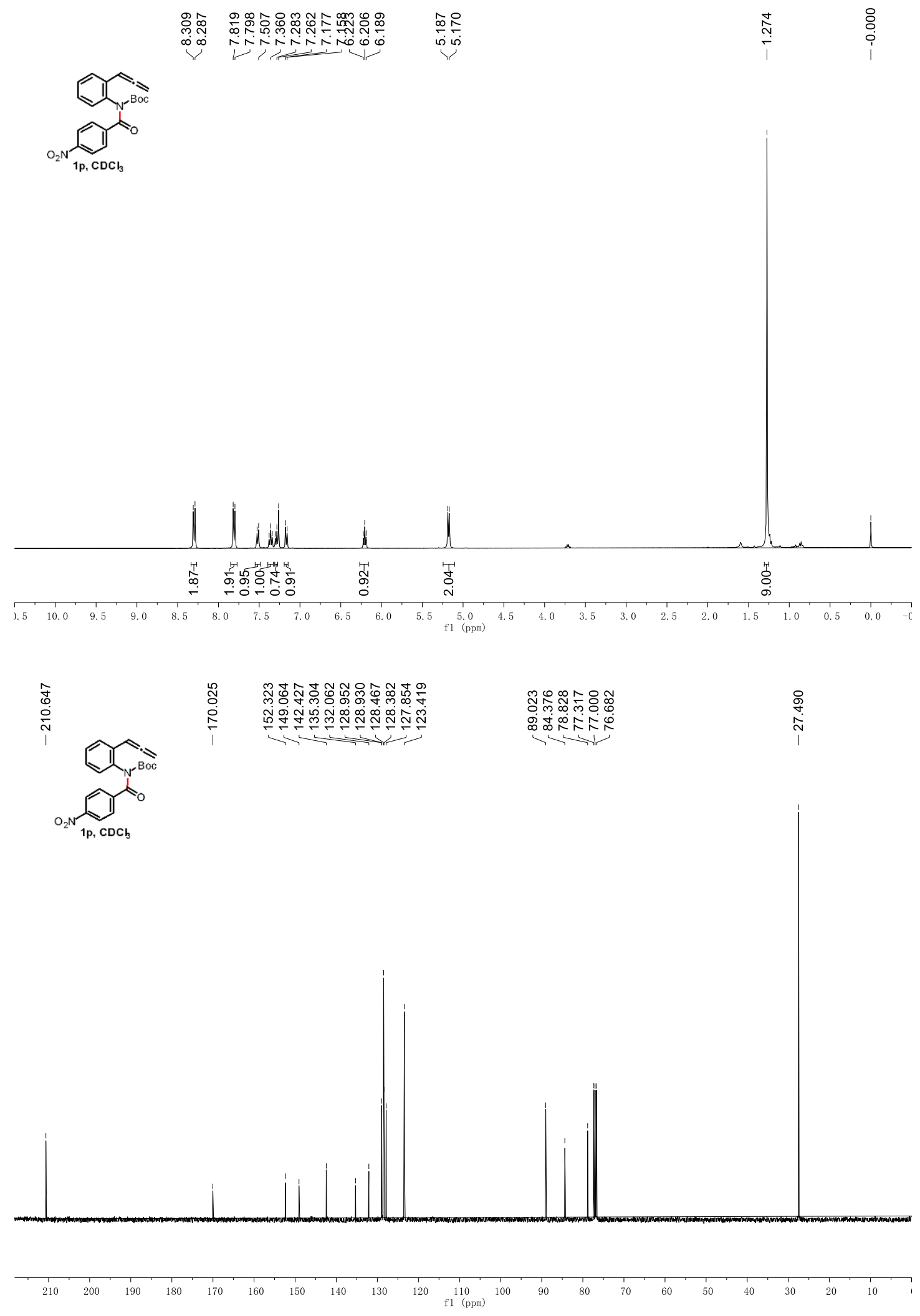




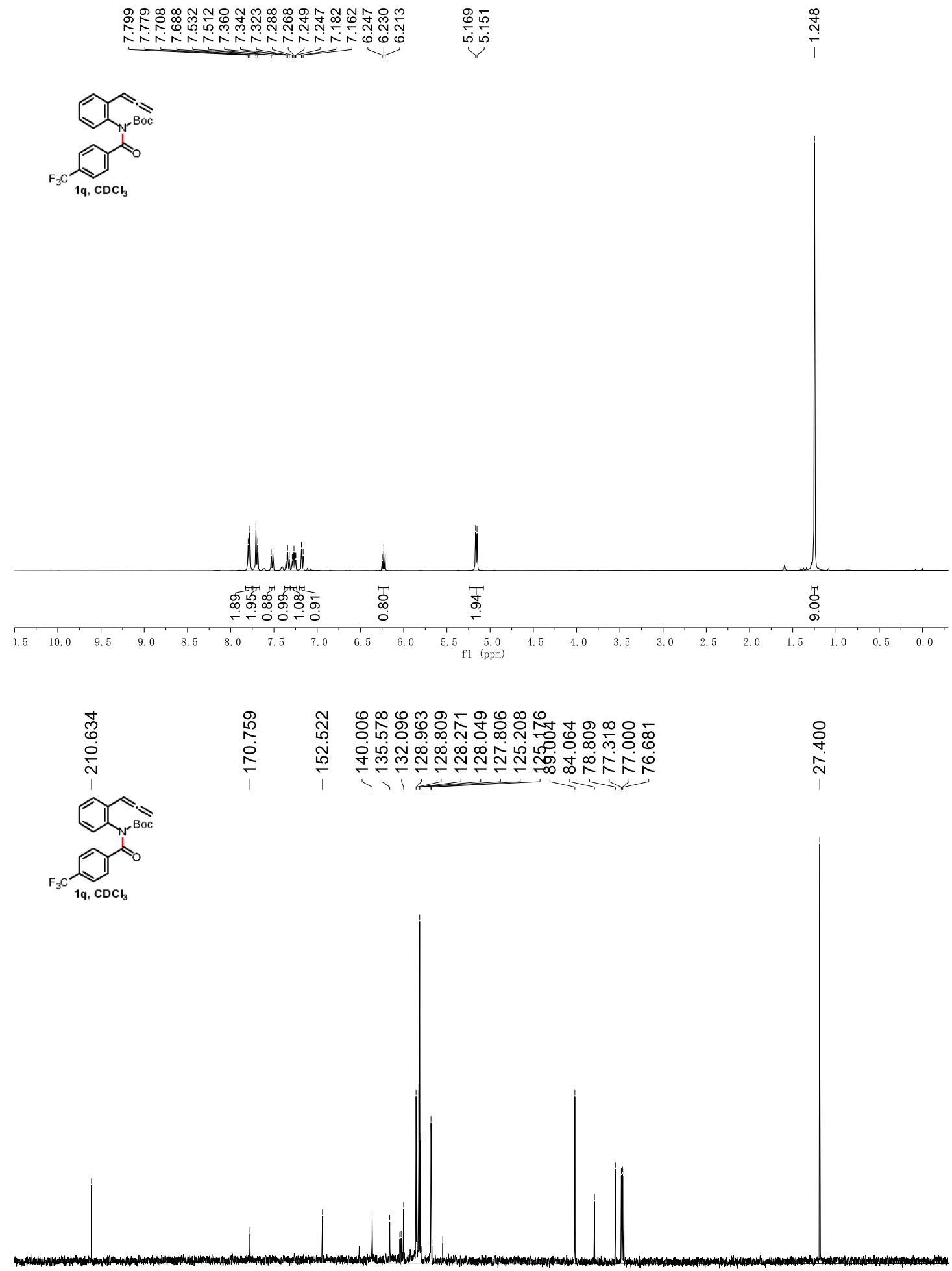

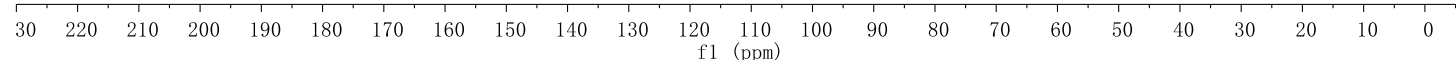




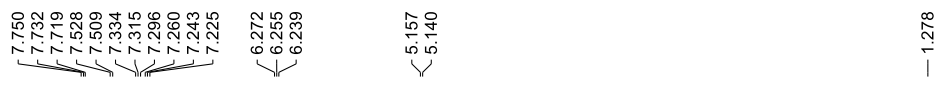
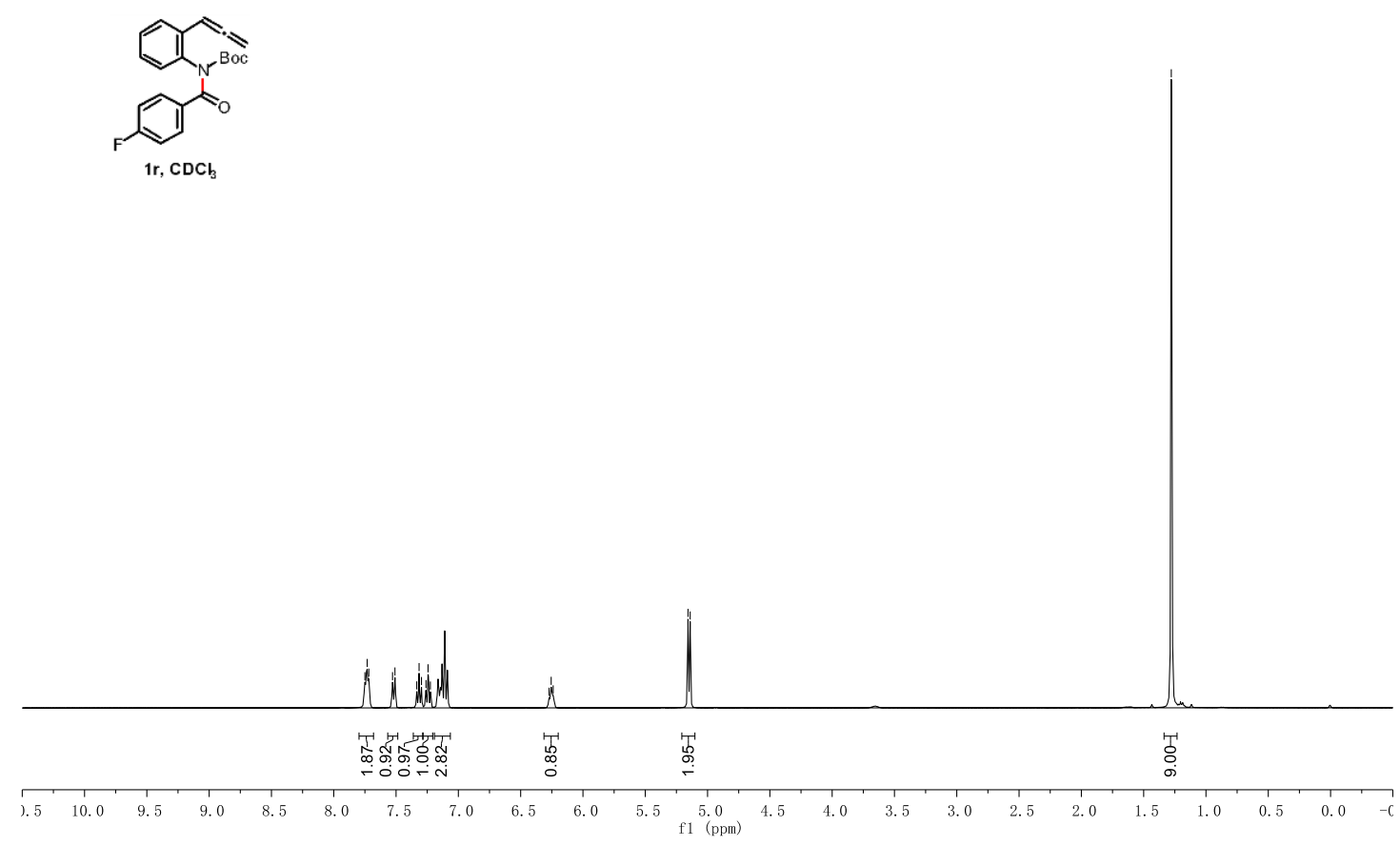

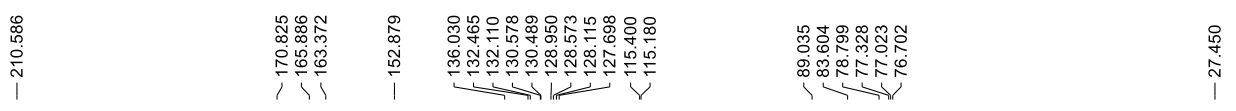
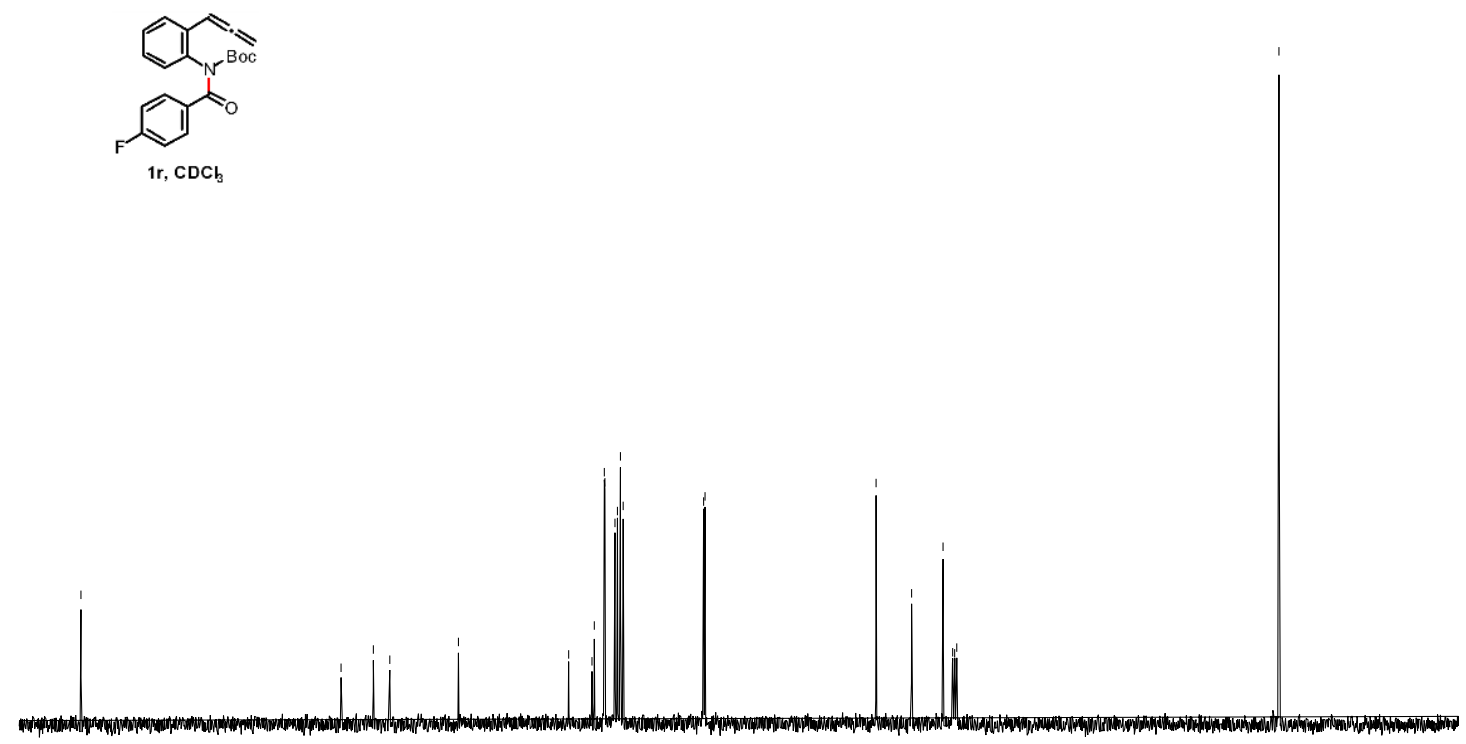

\begin{tabular}{|lllllllllllllllllllll}
1 & 1 & 1 & 1 & 1 & 1 & 1 & 1 & 1 & 1 & 1 & 1 & 1 & 1 & 1 & 1 & 1 & 1 & 1 & 1 & 1 \\
\hline
\end{tabular} 


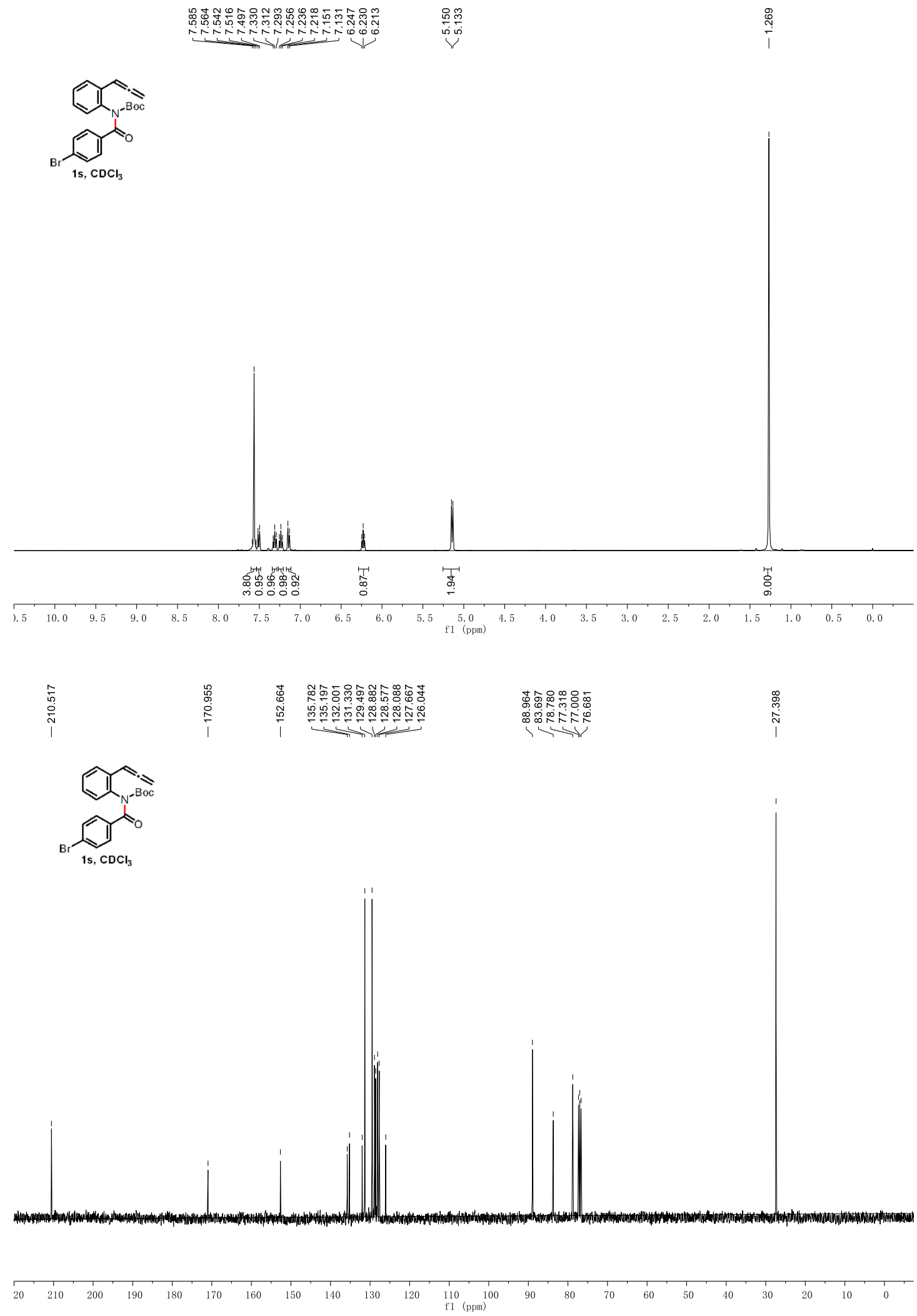




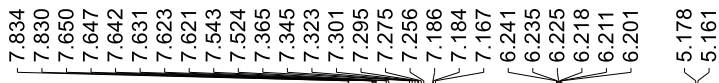

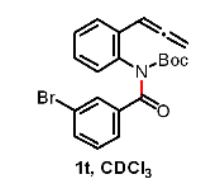

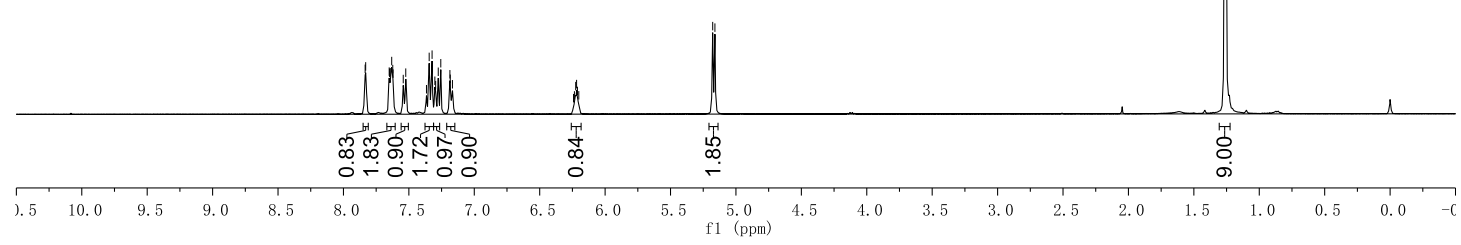

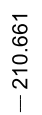

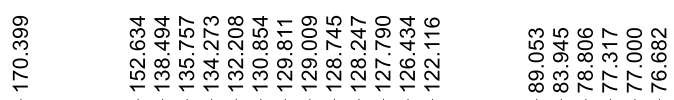
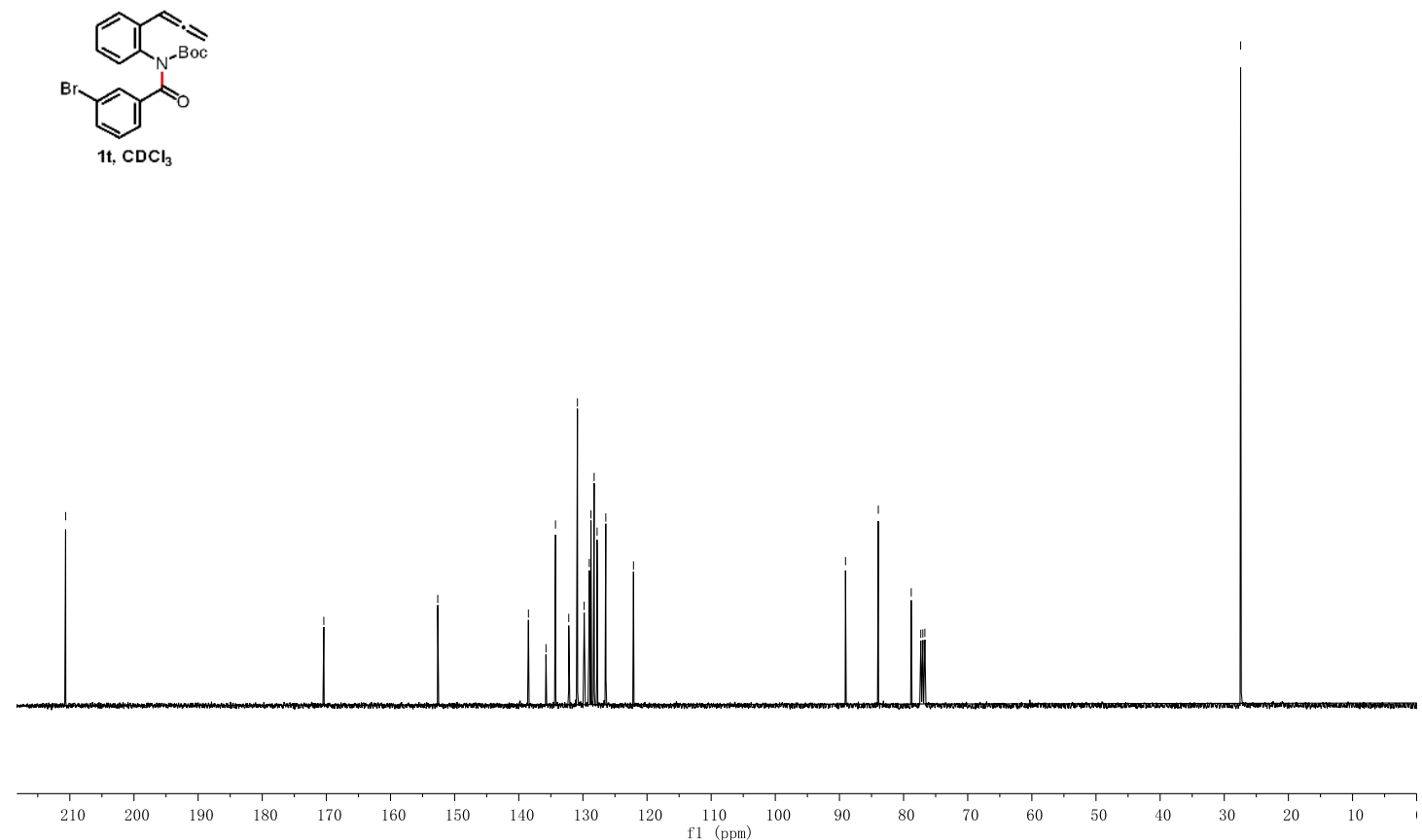

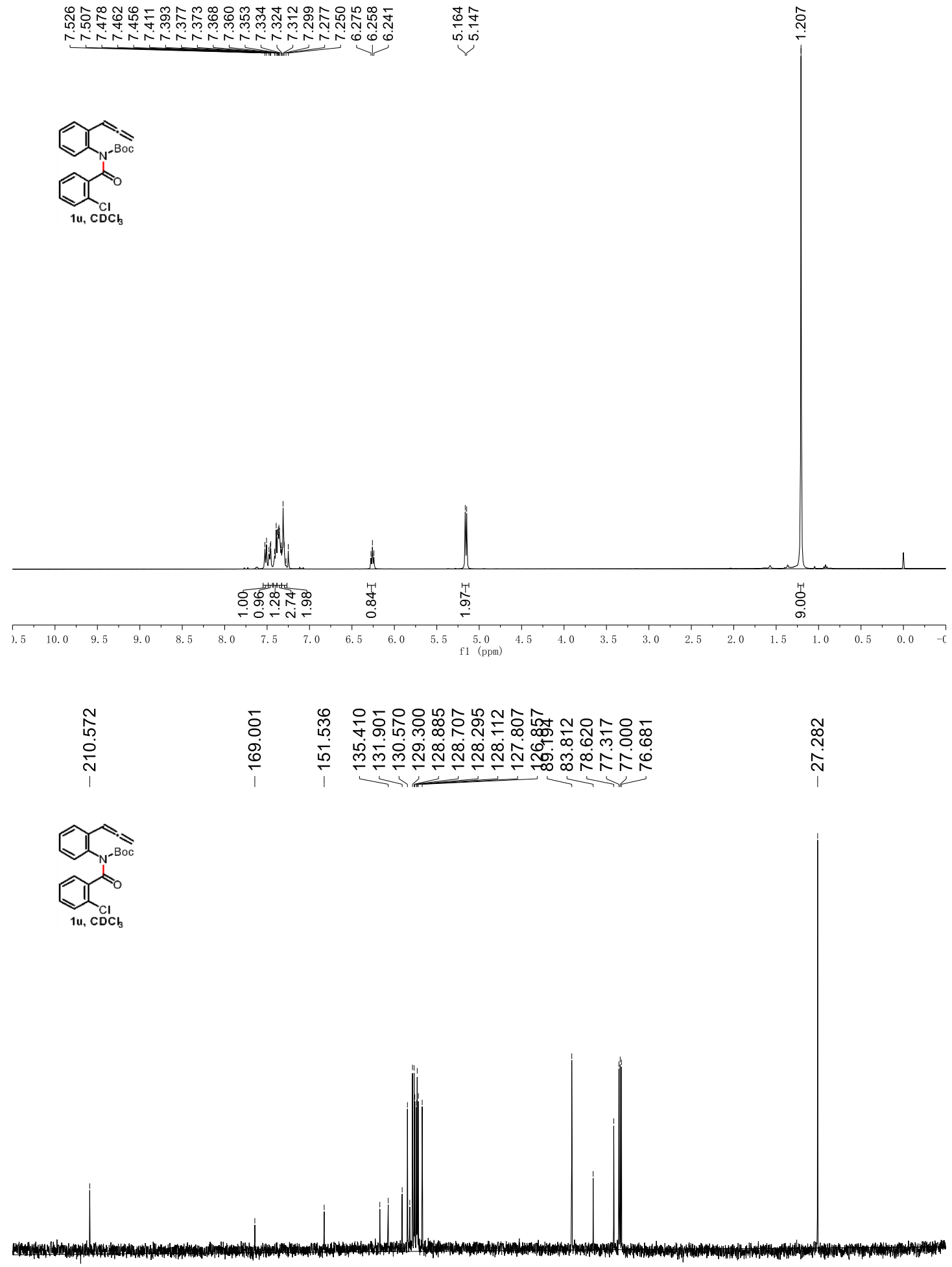

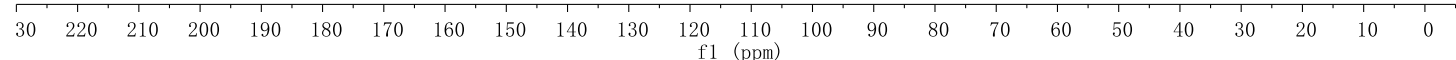




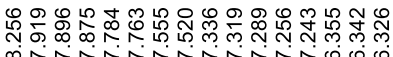

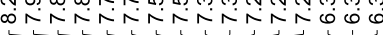
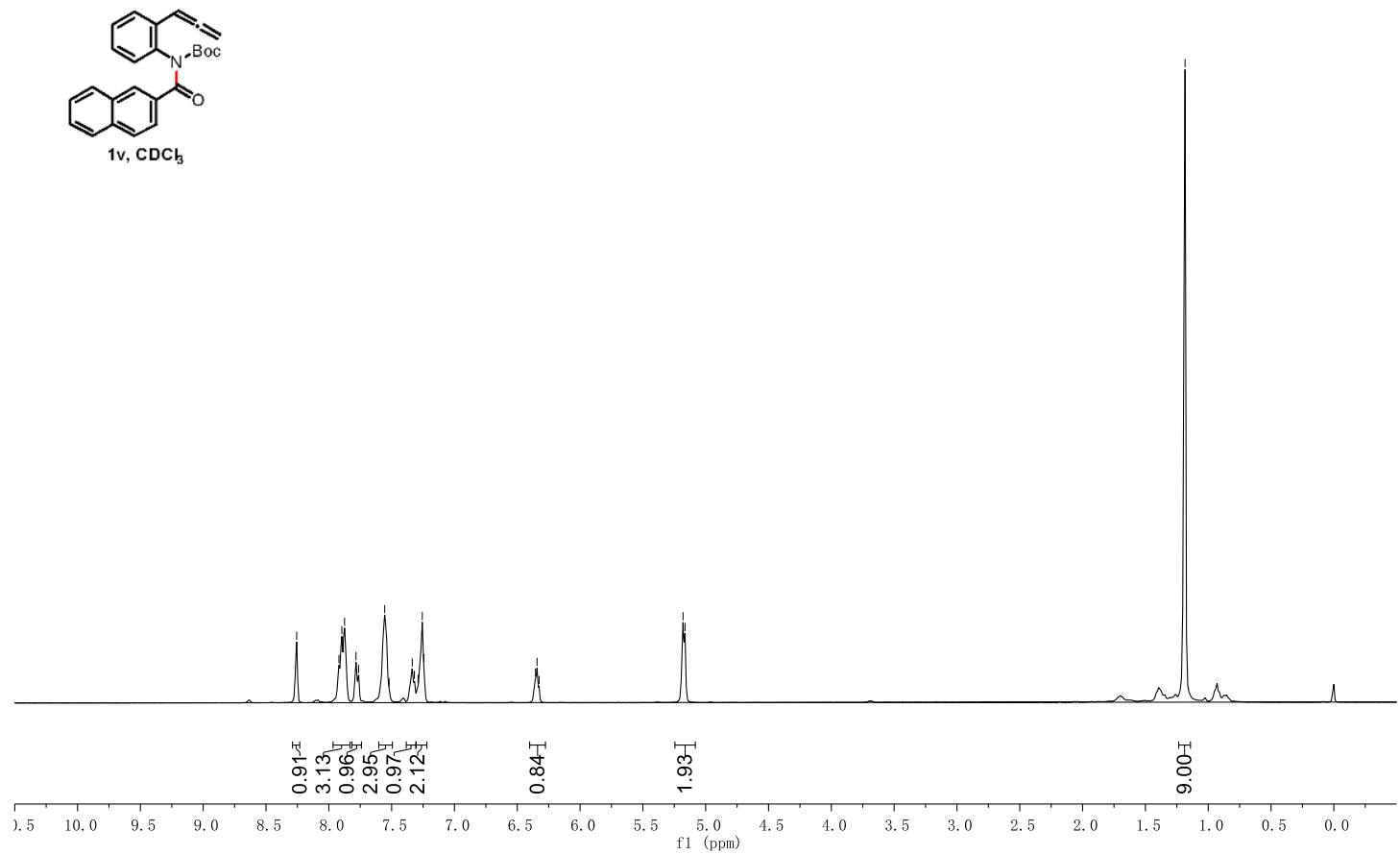

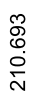

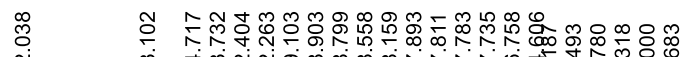

总

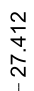
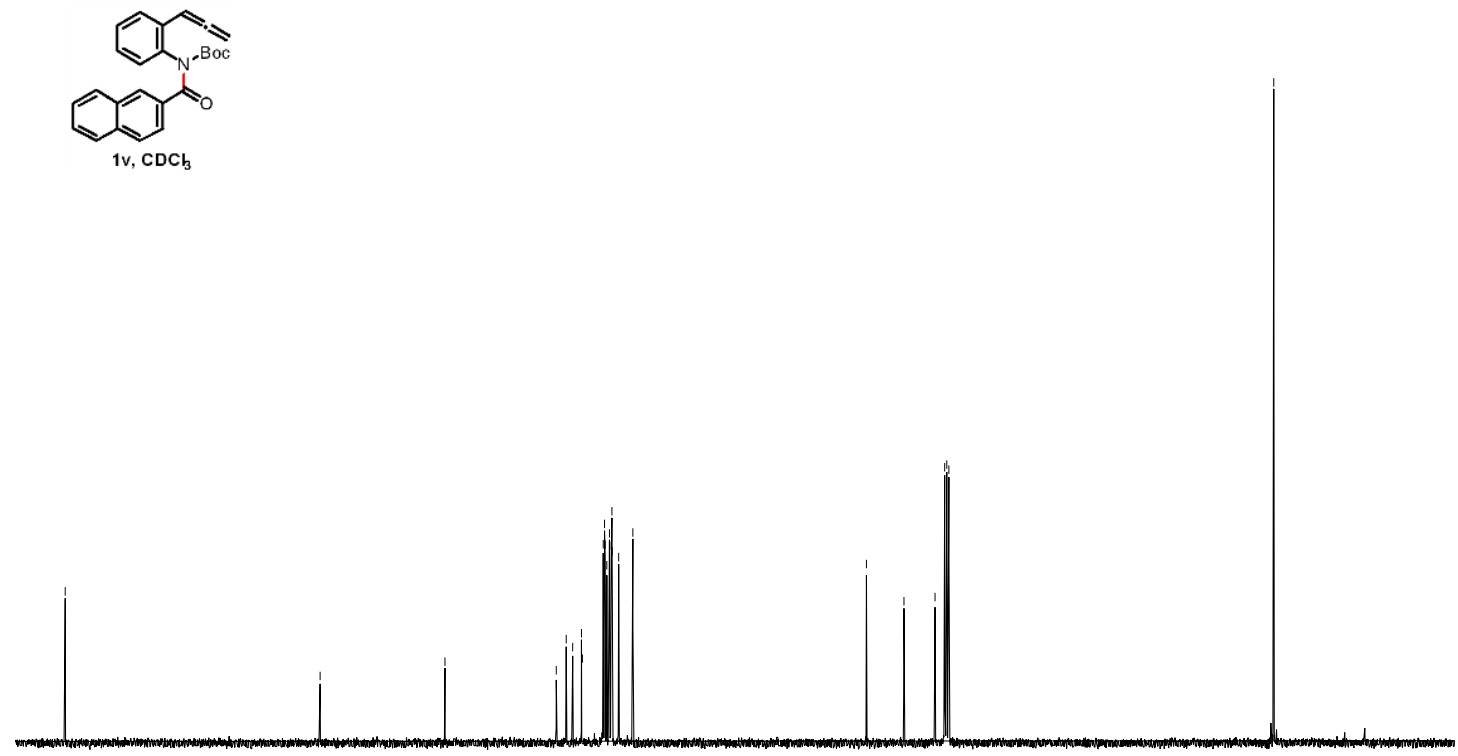

$210 \quad 200 \quad 190$

170

150

$20 \underset{f 1(\mathrm{ppm})}{110} 100$

90

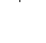

40

20 


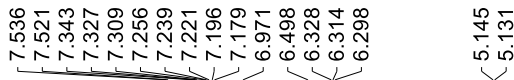

$\overbrace{\mathrm{NB} B \mathrm{OC}}^{\longrightarrow}$

iilo

1w, $\mathrm{CDCl}_{3}$

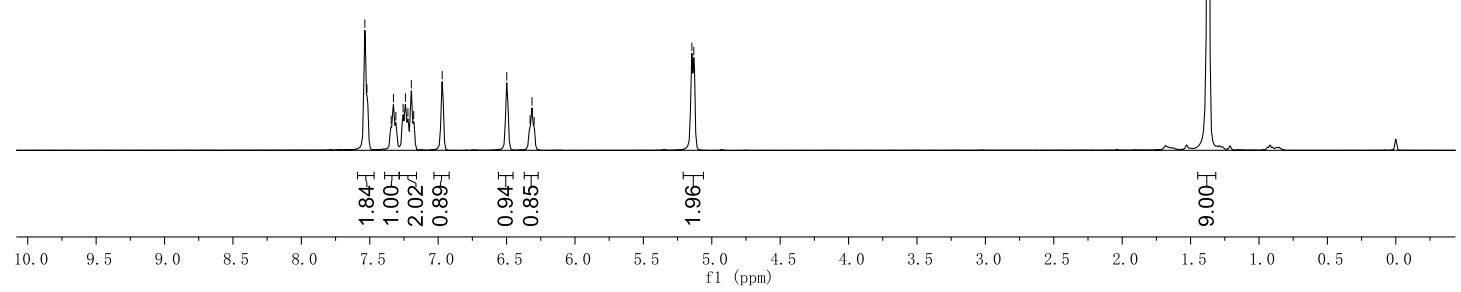

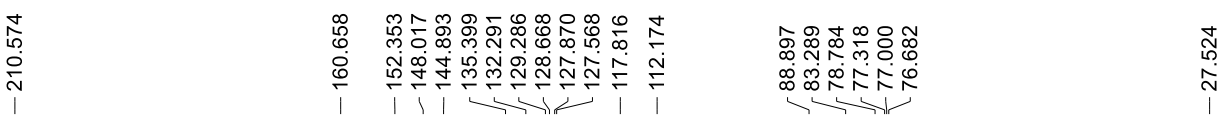

$\mathrm{Sl}_{\mathrm{N}^{-B O C}}^{\mathrm{B}}$

i1

$1 \mathrm{w}, \mathrm{CDCl}_{3}$

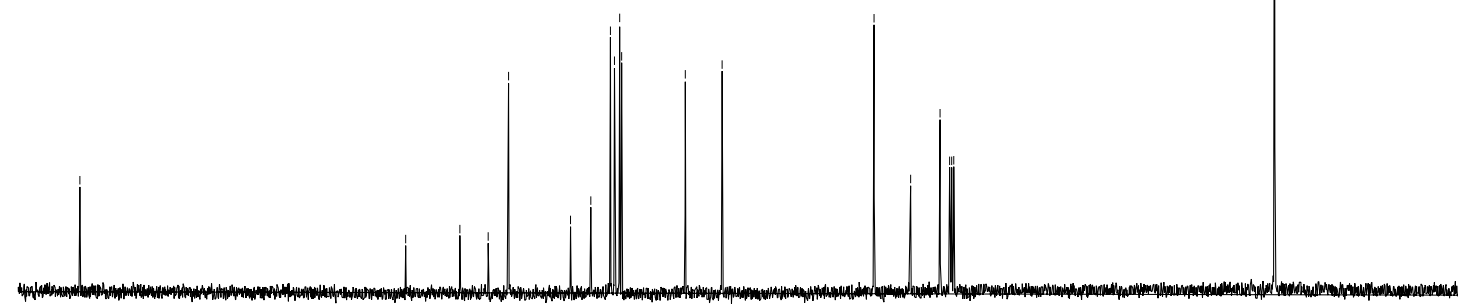

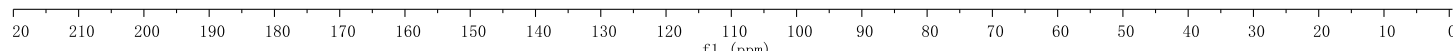




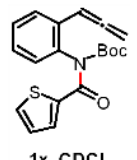

$1 \mathrm{x}, \mathrm{CDCl}_{3}$
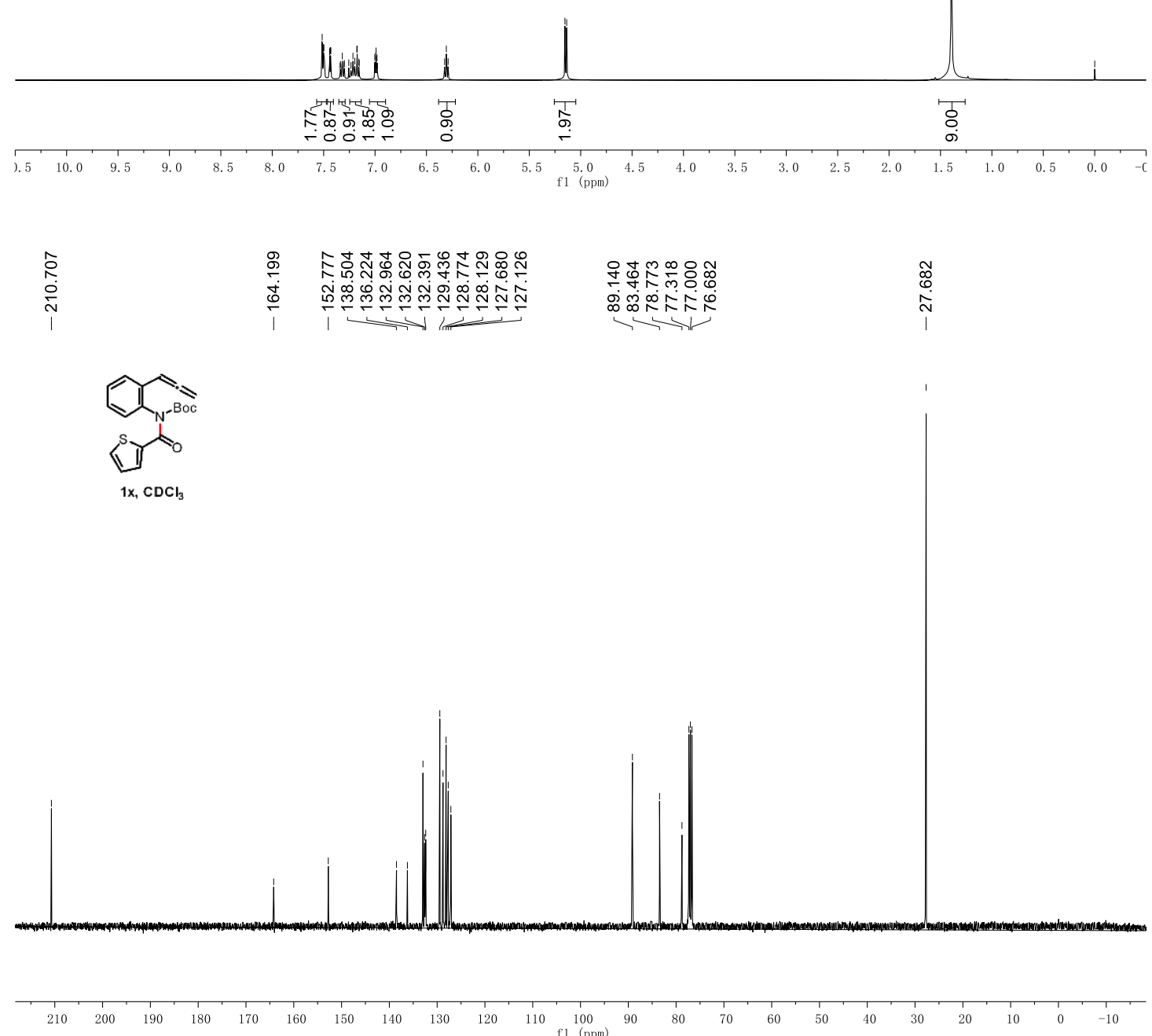


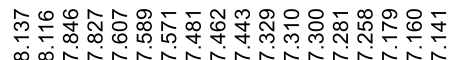

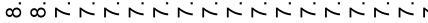

$N_{M e}^{\substack{n \\ B o c}}$

$\begin{array}{lll}\stackrel{0}{0} & \stackrel{0}{0} & \stackrel{0}{0} \\ \stackrel{1}{i} & 0\end{array}$

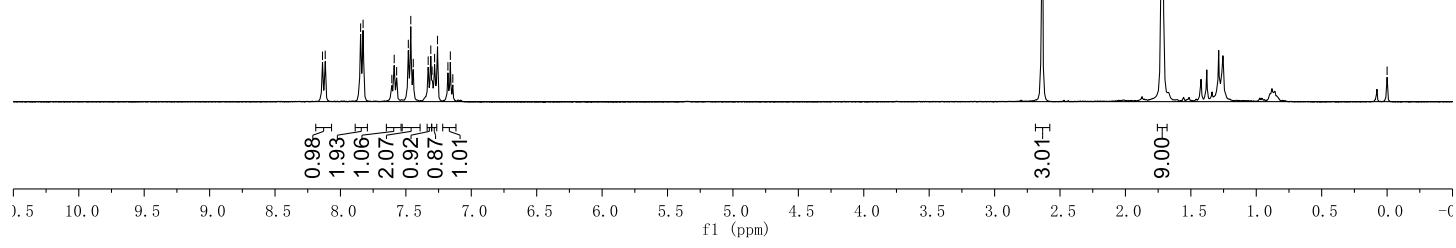

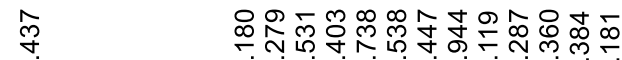

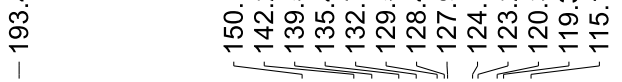

ลิ่า

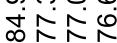

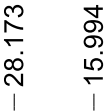

$\underbrace{i N / p h}_{\substack{\text { Boc } \\ \text { Me }}}$

2a, $\mathrm{CDCl}_{3}$

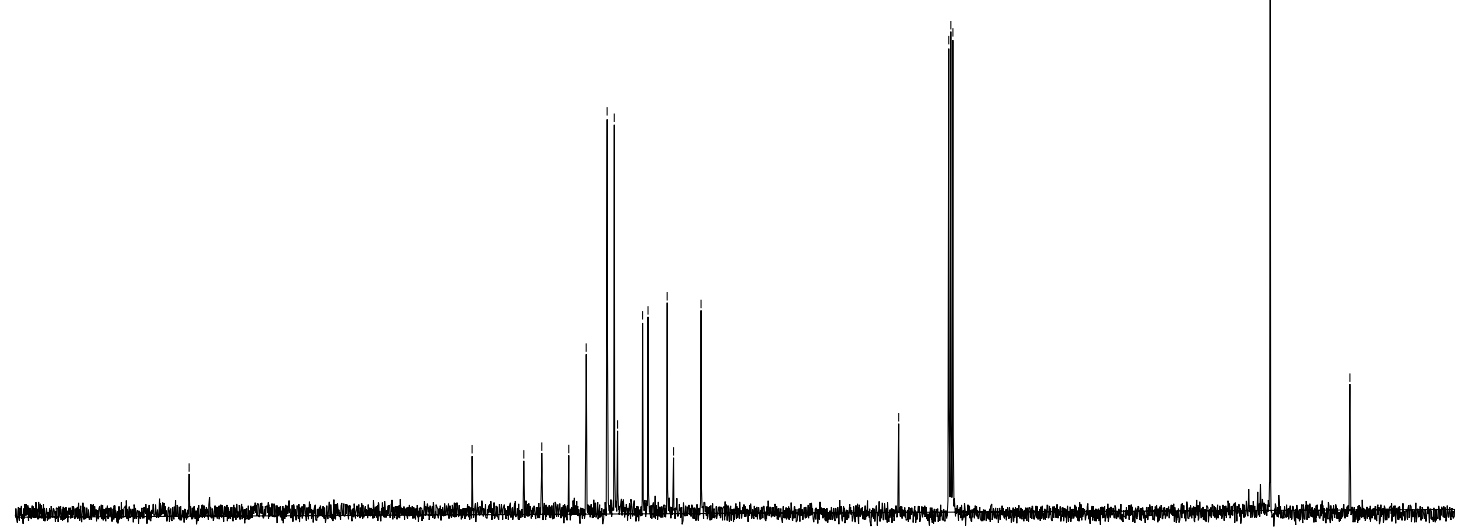

$\begin{array}{llllllllllllllllllllll}20 & 210 & 200 & 190 & 180 & 170 & 160 & 150 & 140 & 130 & 120 & 110 & 100 & 90 & 80 & 70 & 60 & 50 & 40 & 30 & 20 & 10\end{array}$ 


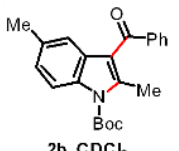

2b, $\mathrm{CDCl}_{3}$

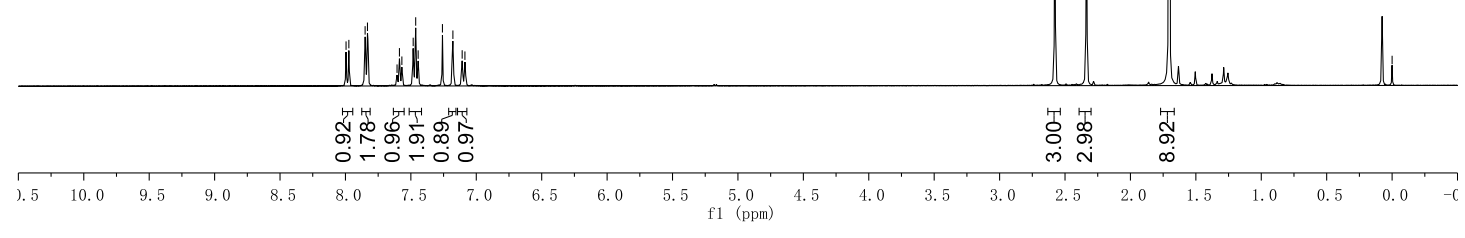

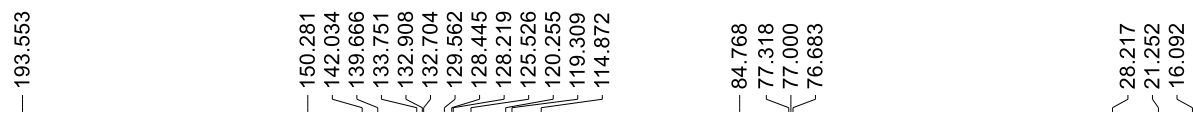
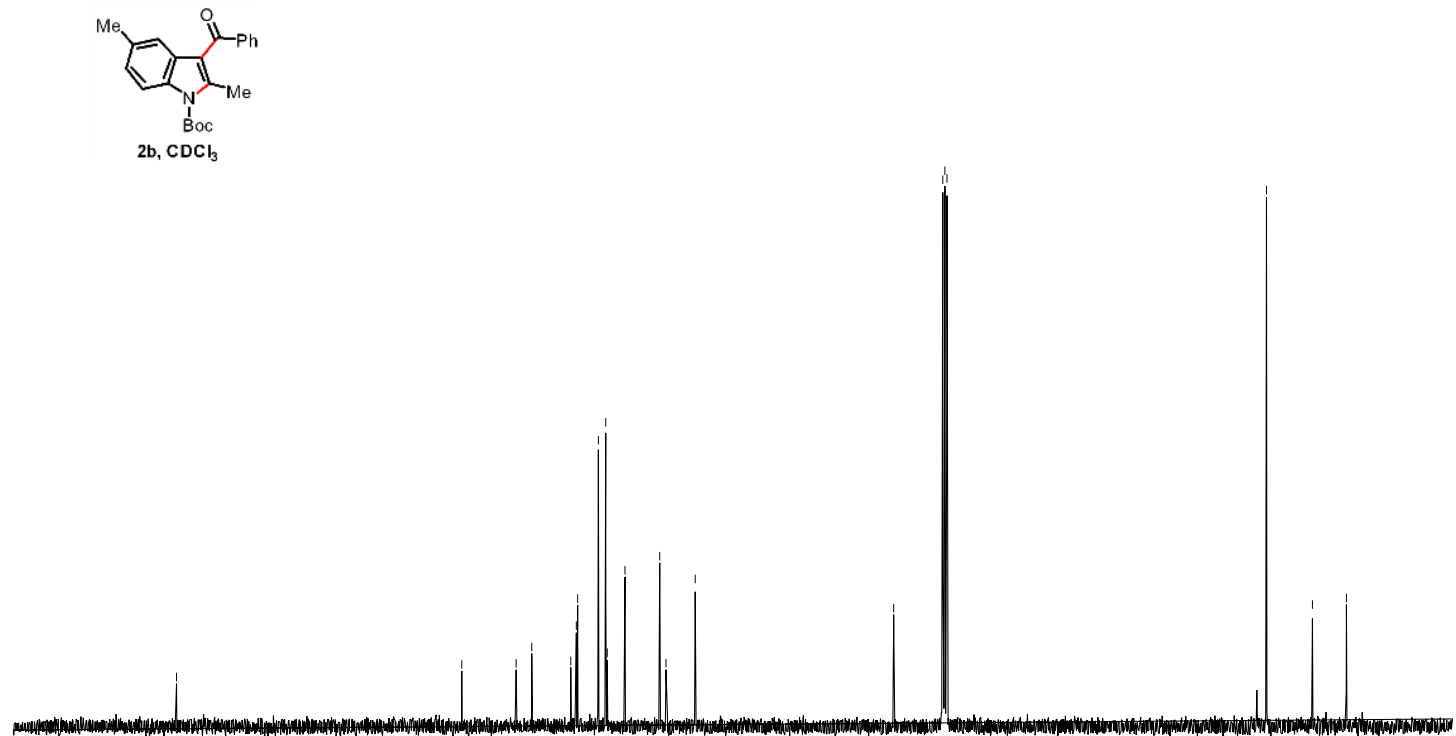

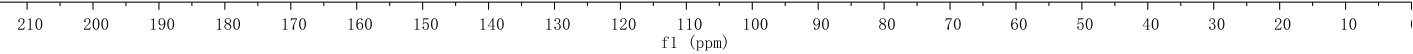



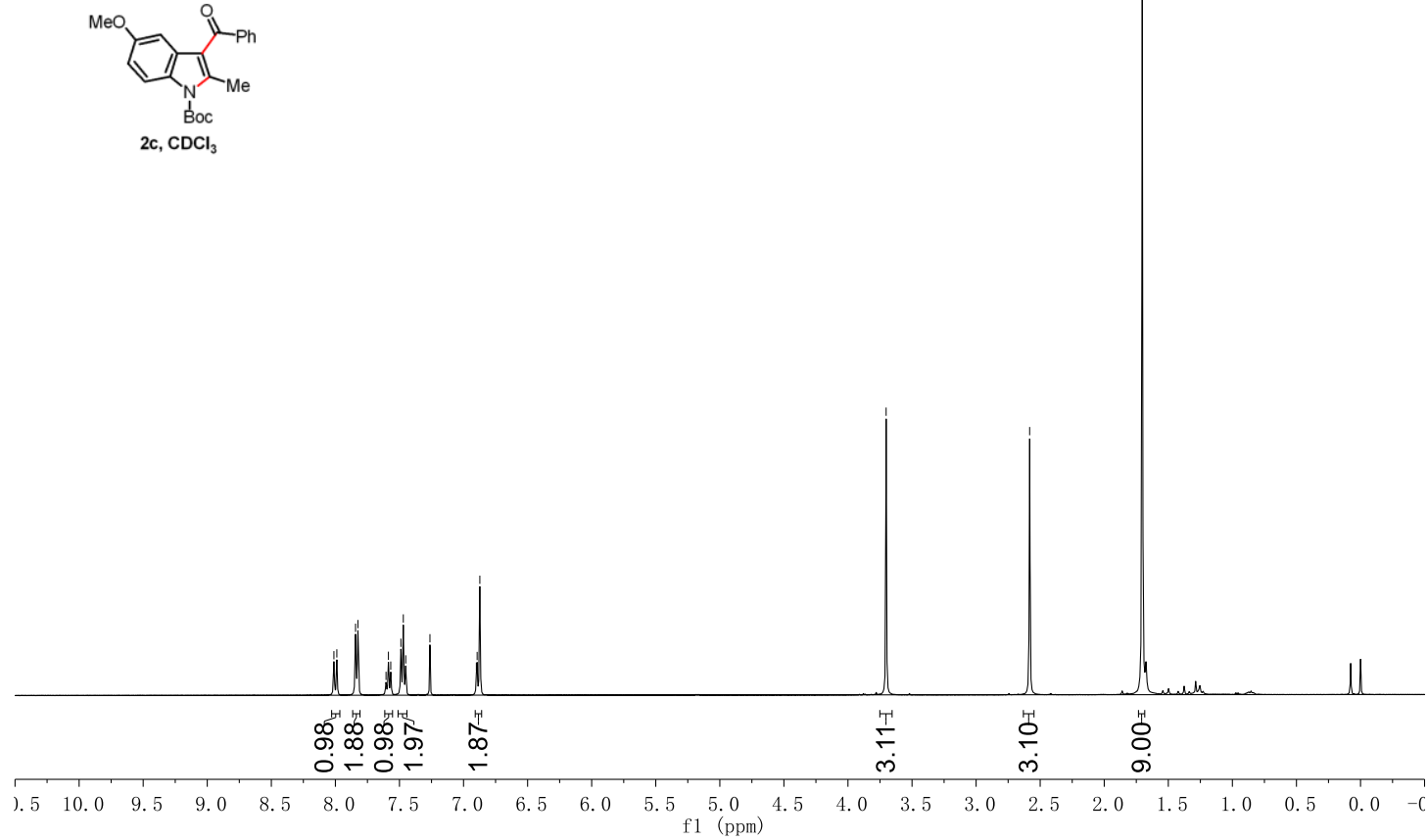

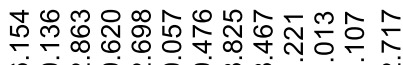
ம்

꾸용

赫余

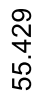

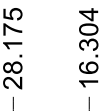

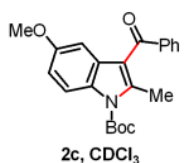

2c, $\mathrm{CDCl}_{3}$

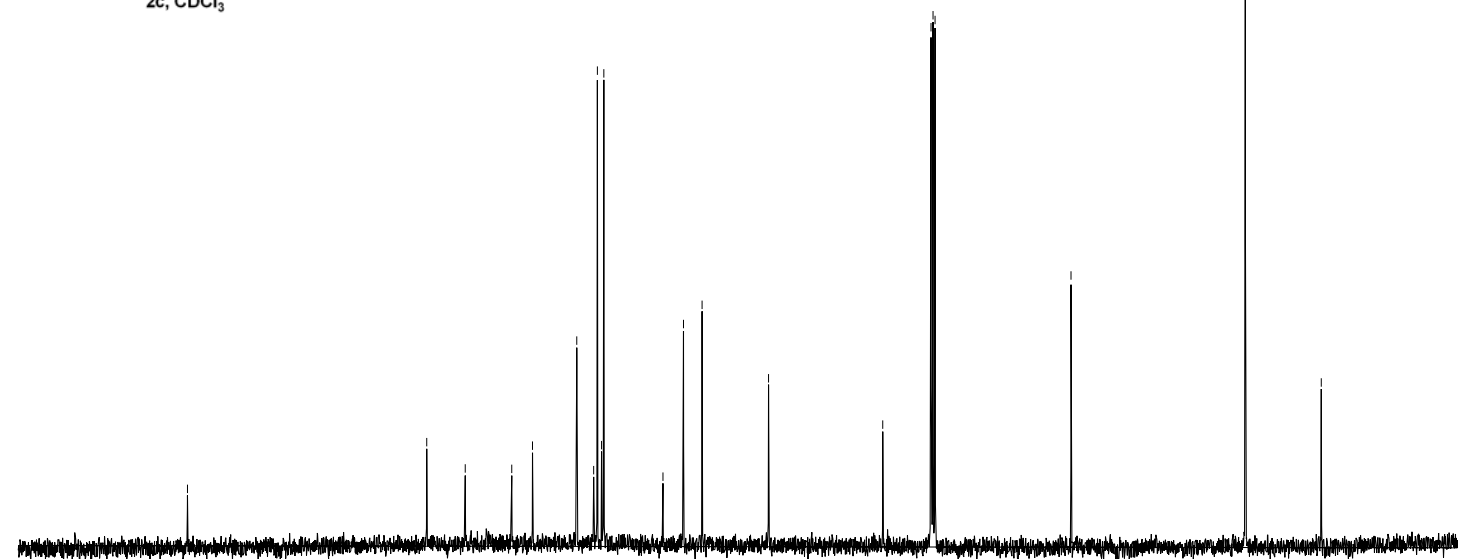

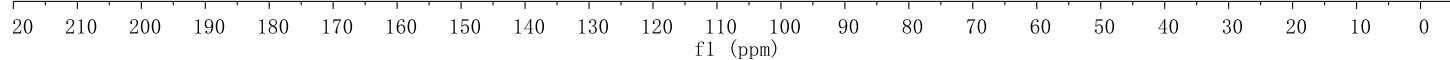



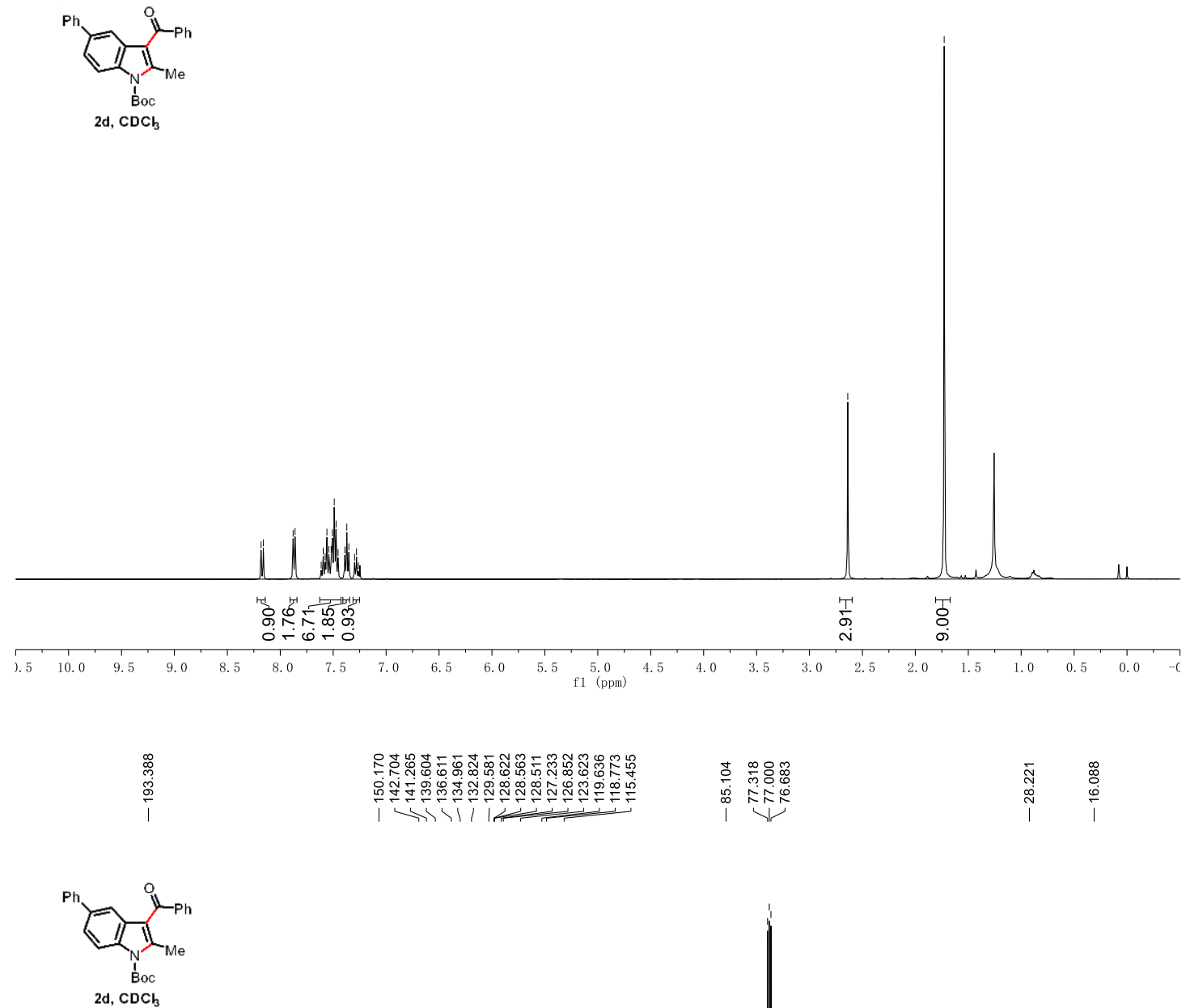

2d, $\mathrm{CDCl}_{3}$
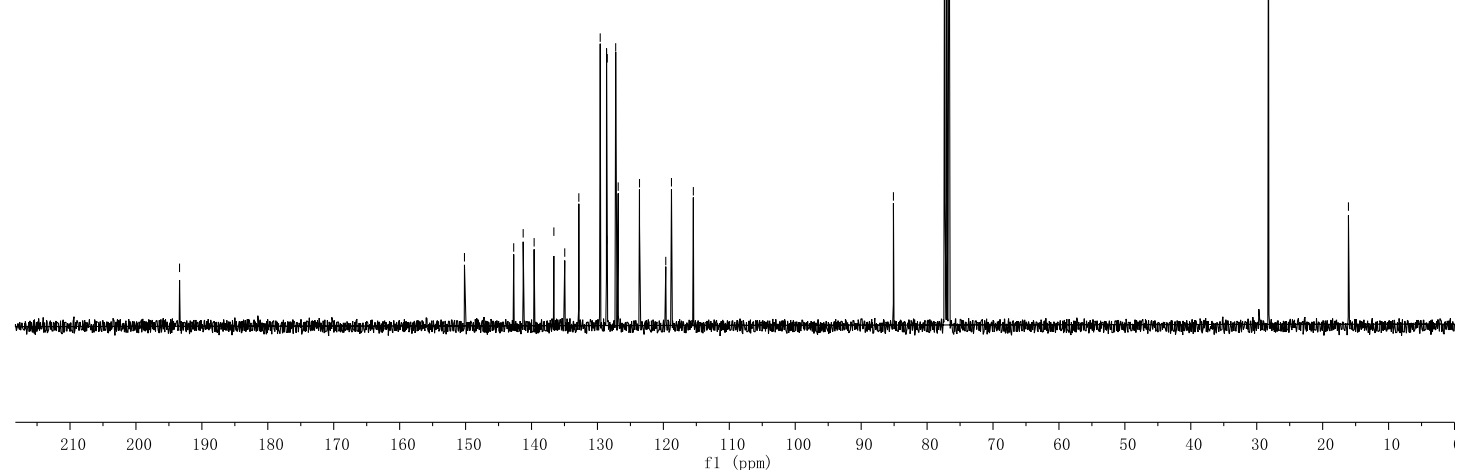


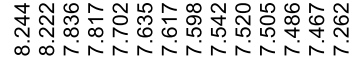

$\underset{\substack{i\\}}{\stackrel{i}{N}}$

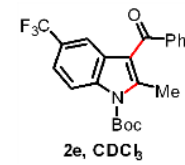

$\mathrm{CDC}$

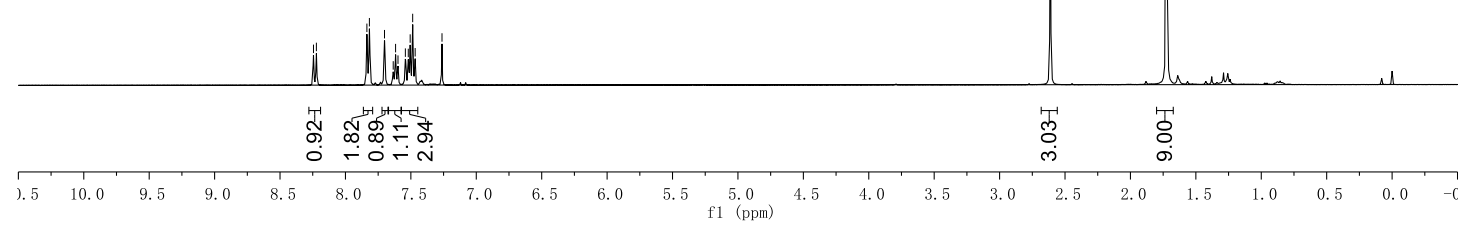

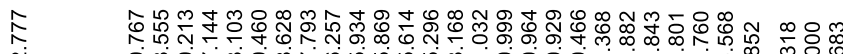

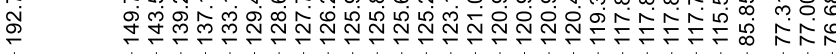

$\begin{array}{ll}m \\ \stackrel{0}{0} & \stackrel{0}{0} \\ \stackrel{\infty}{\infty} & \stackrel{0}{0} \\ 1 & 1\end{array}$
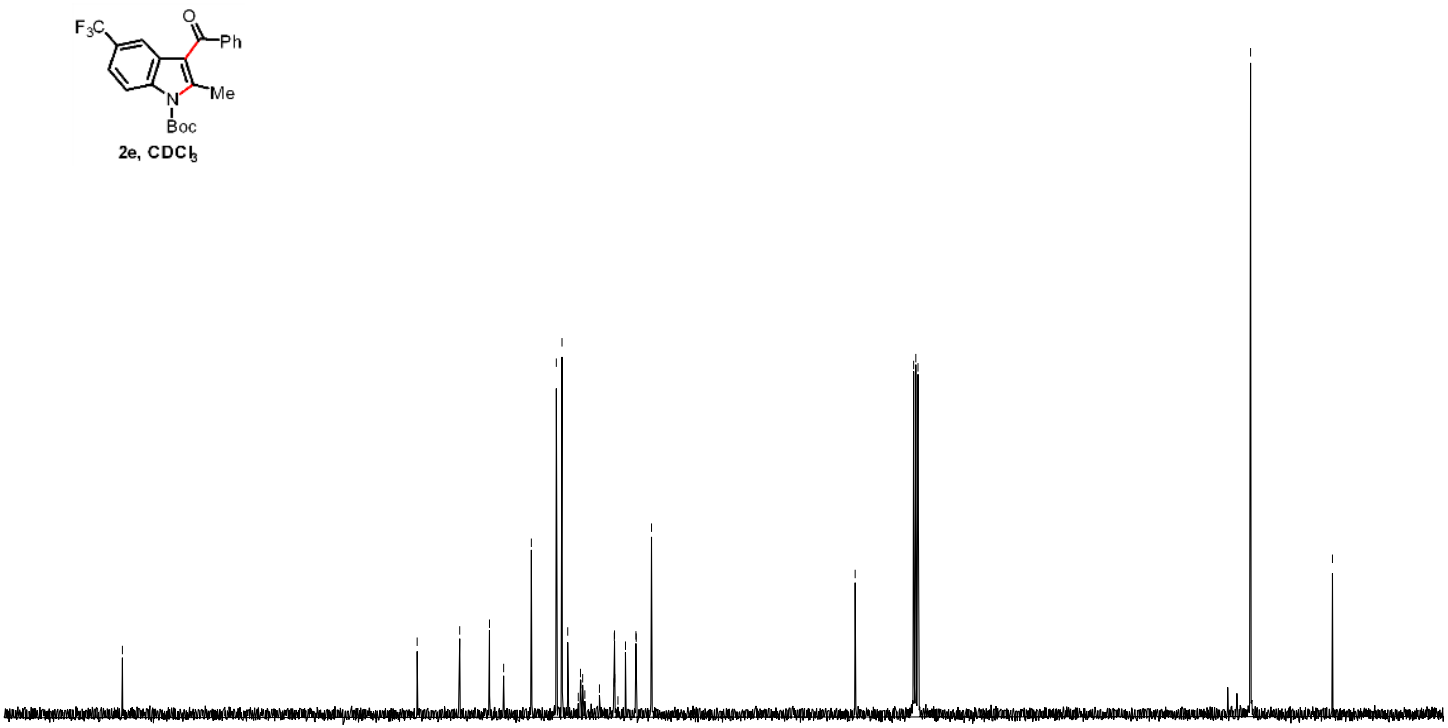

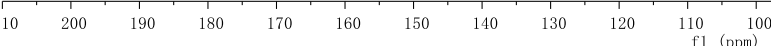




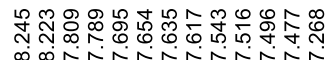

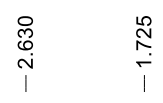

acc
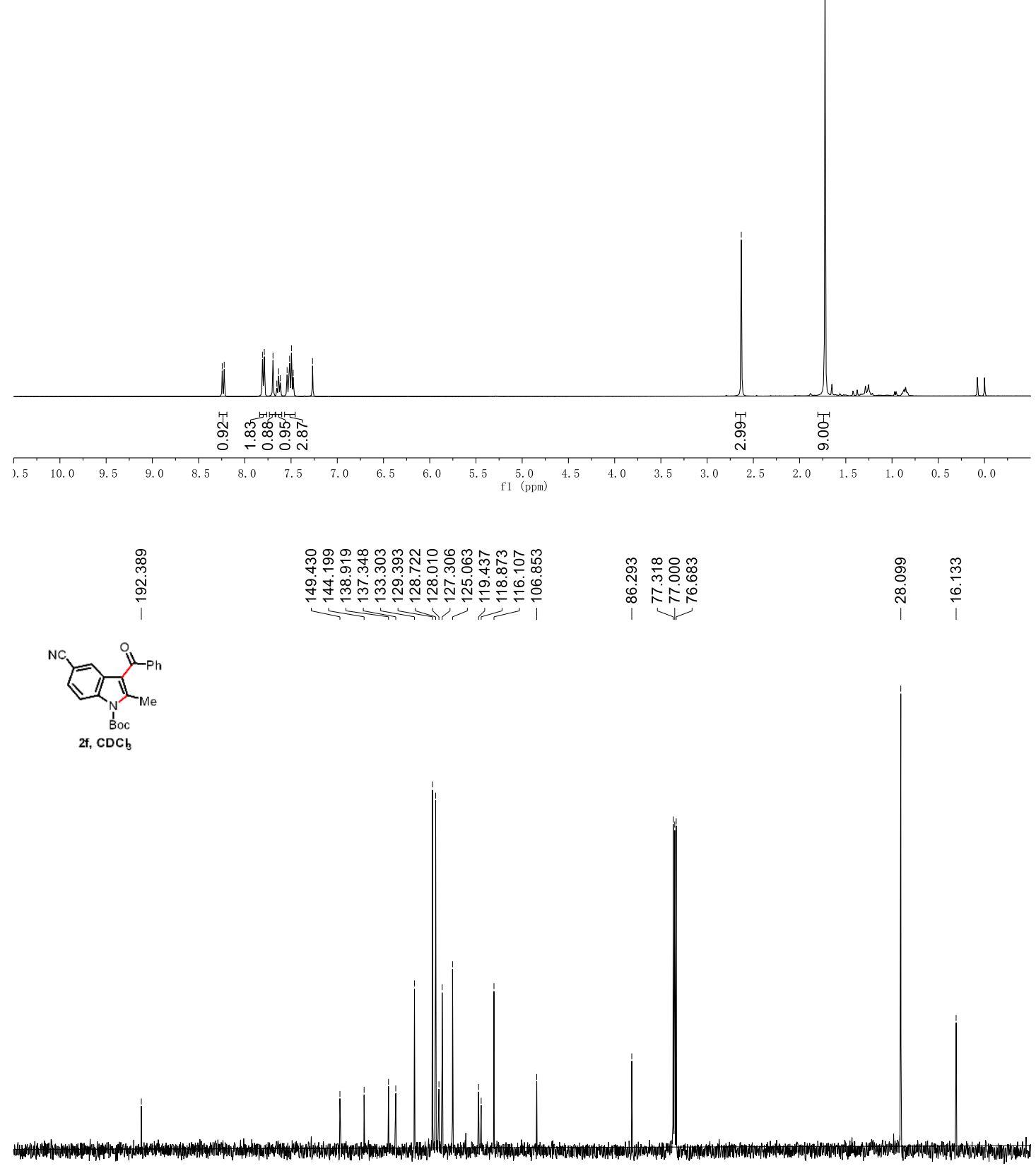

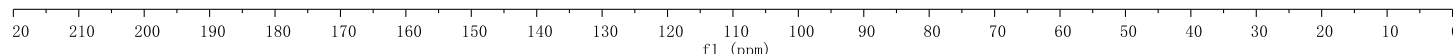




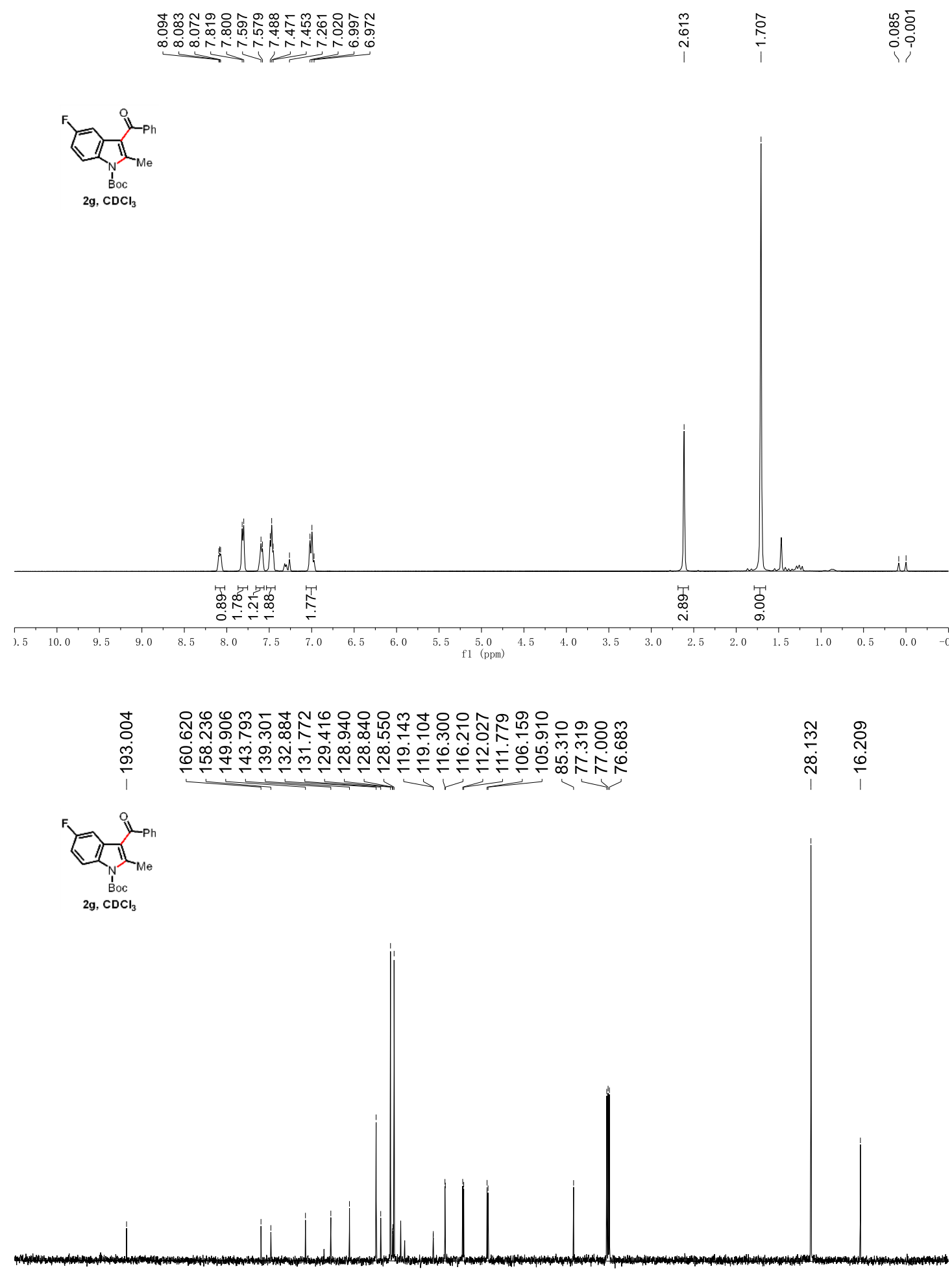

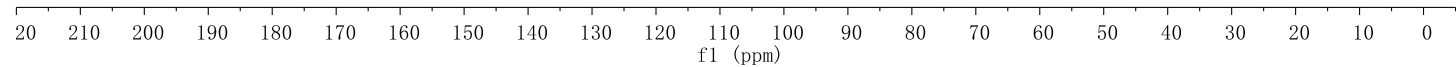




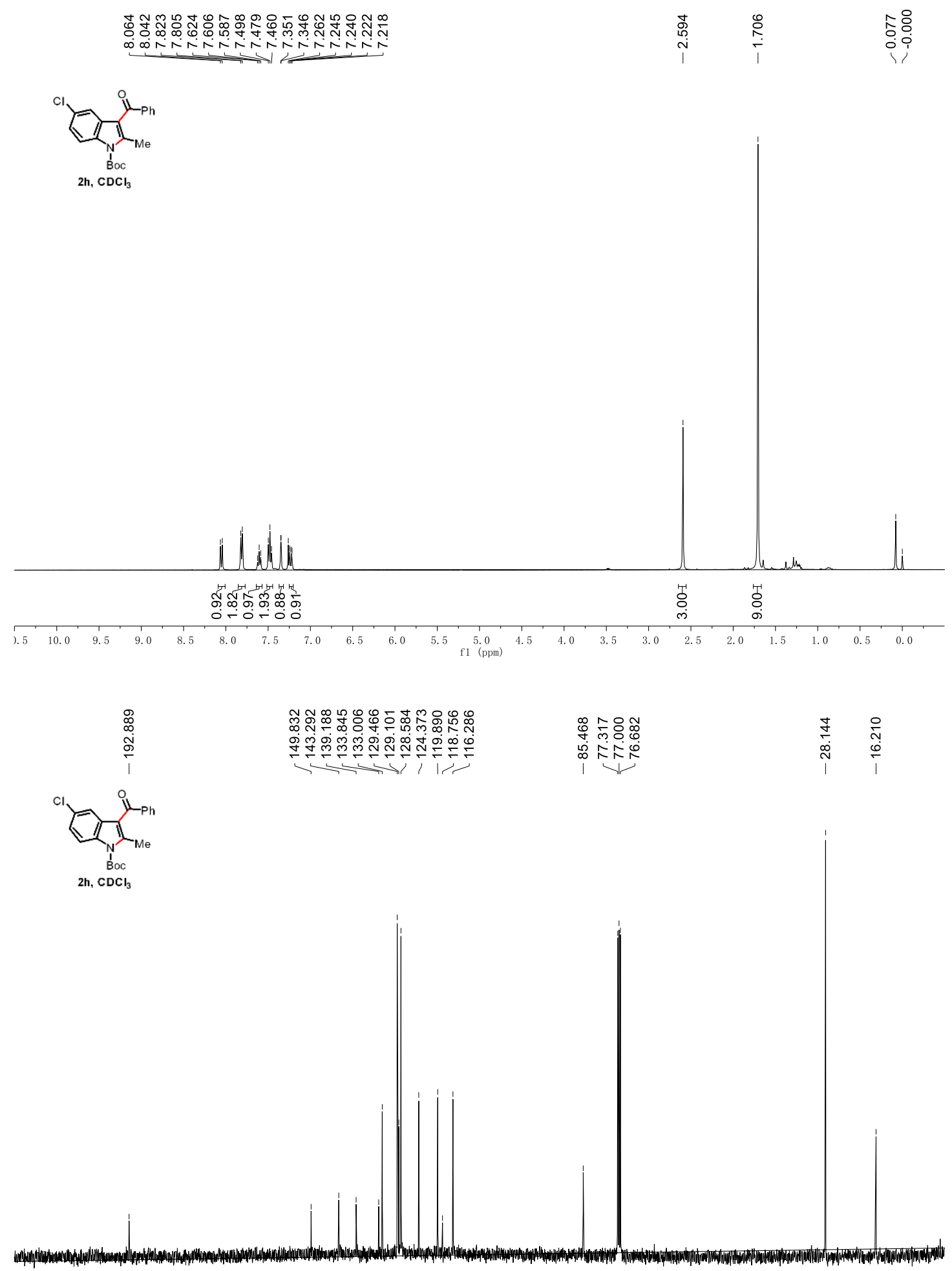

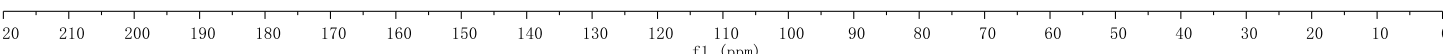



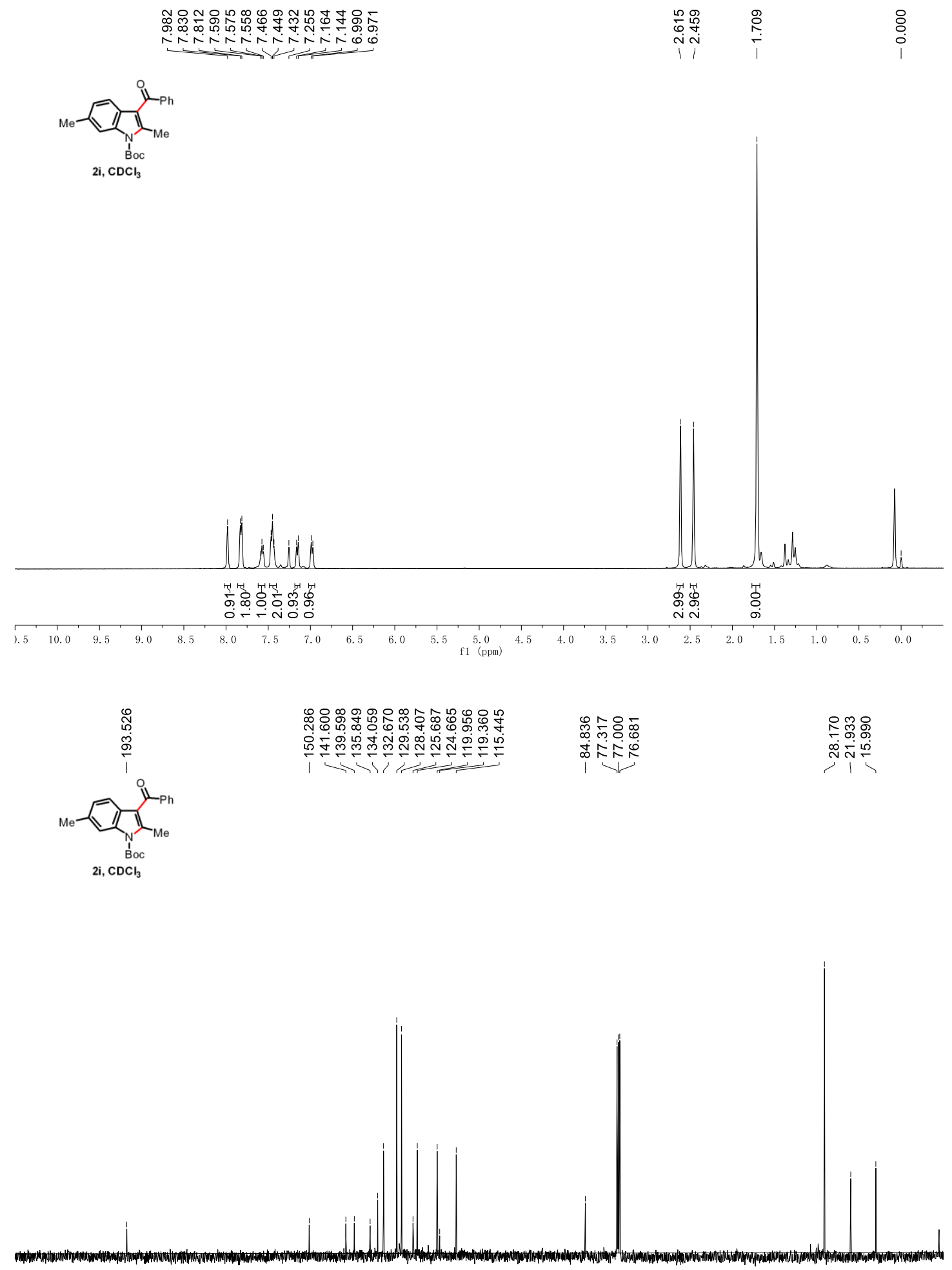

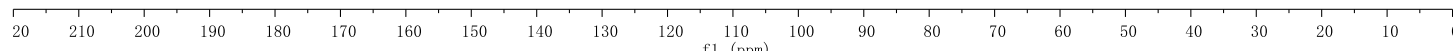



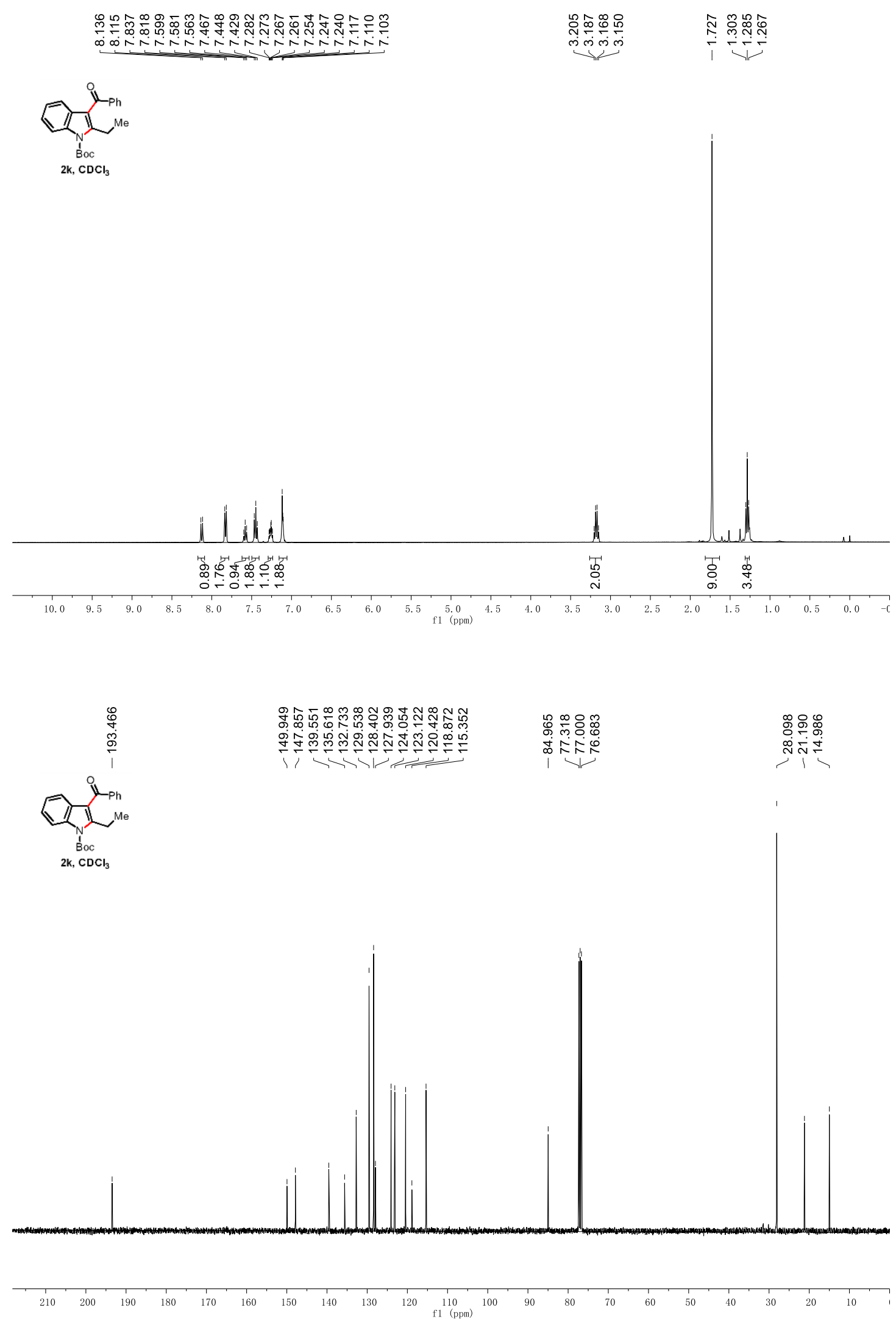


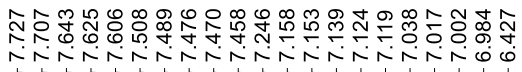

ঙำ

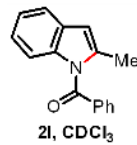

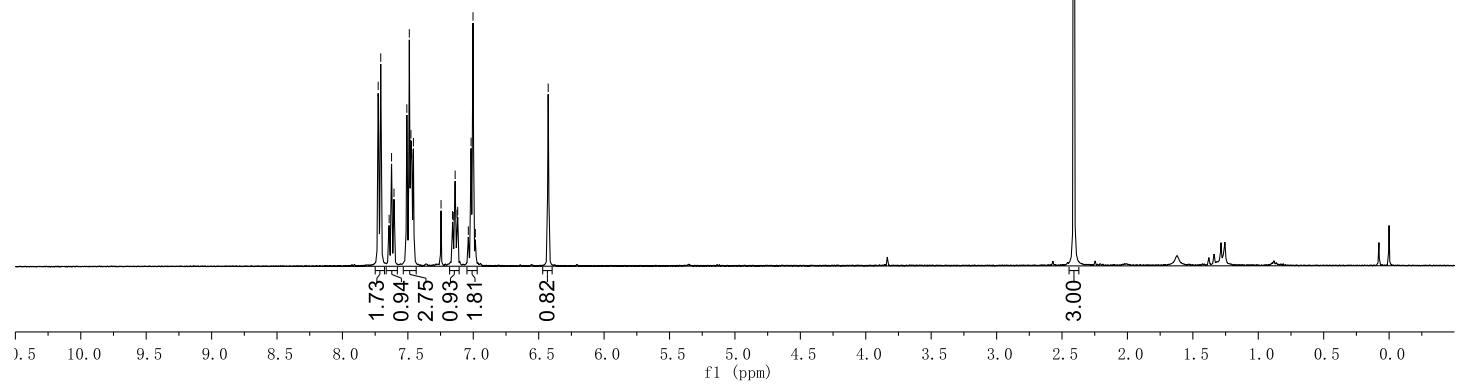




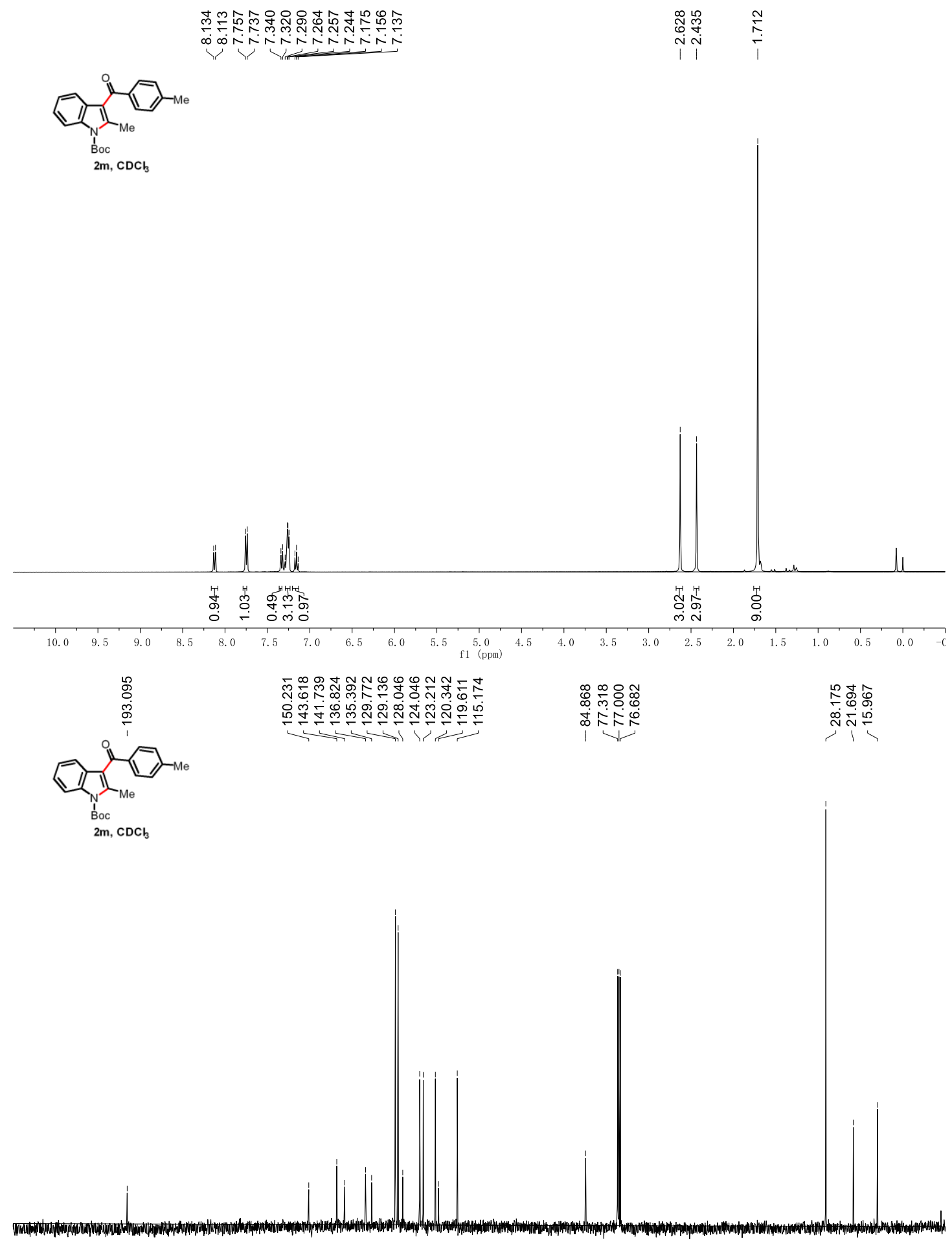

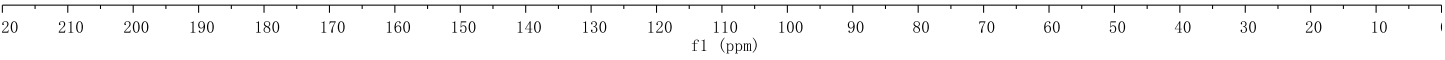




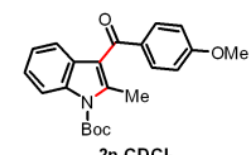

$2 \mathrm{n} \mathrm{CDCl}_{3}$
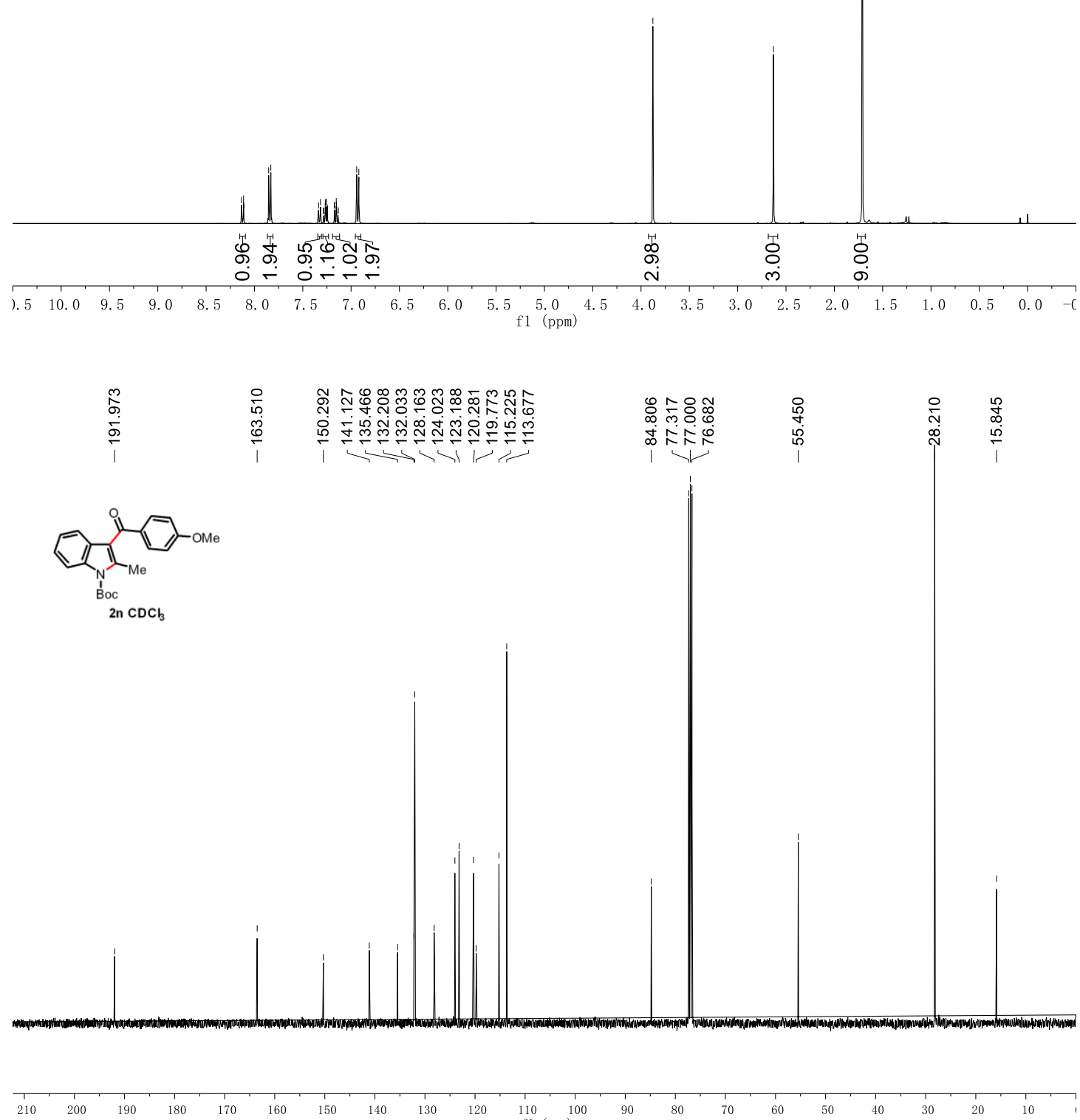

${ }_{\mathrm{f} 1}^{110}(\mathrm{ppm})$ 

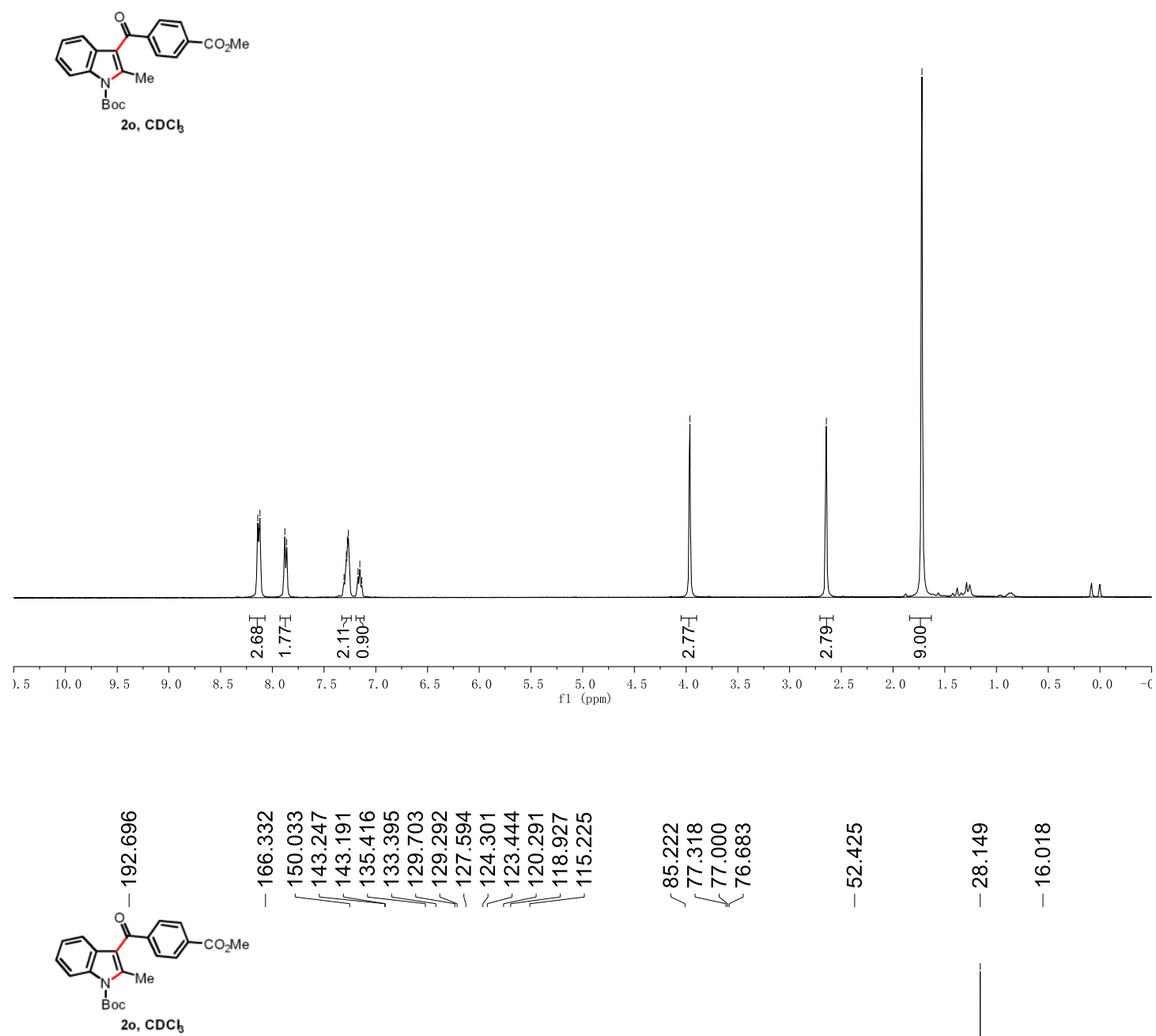

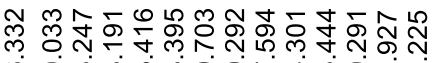

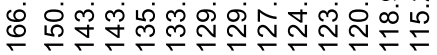

ฟิ๊

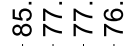

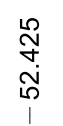

$\begin{array}{ll}\stackrel{g}{+} & \infty \\ \infty & 0 \\ \sim & 0 \\ 1 & 0\end{array}$

2o, $\mathrm{CDCb}$

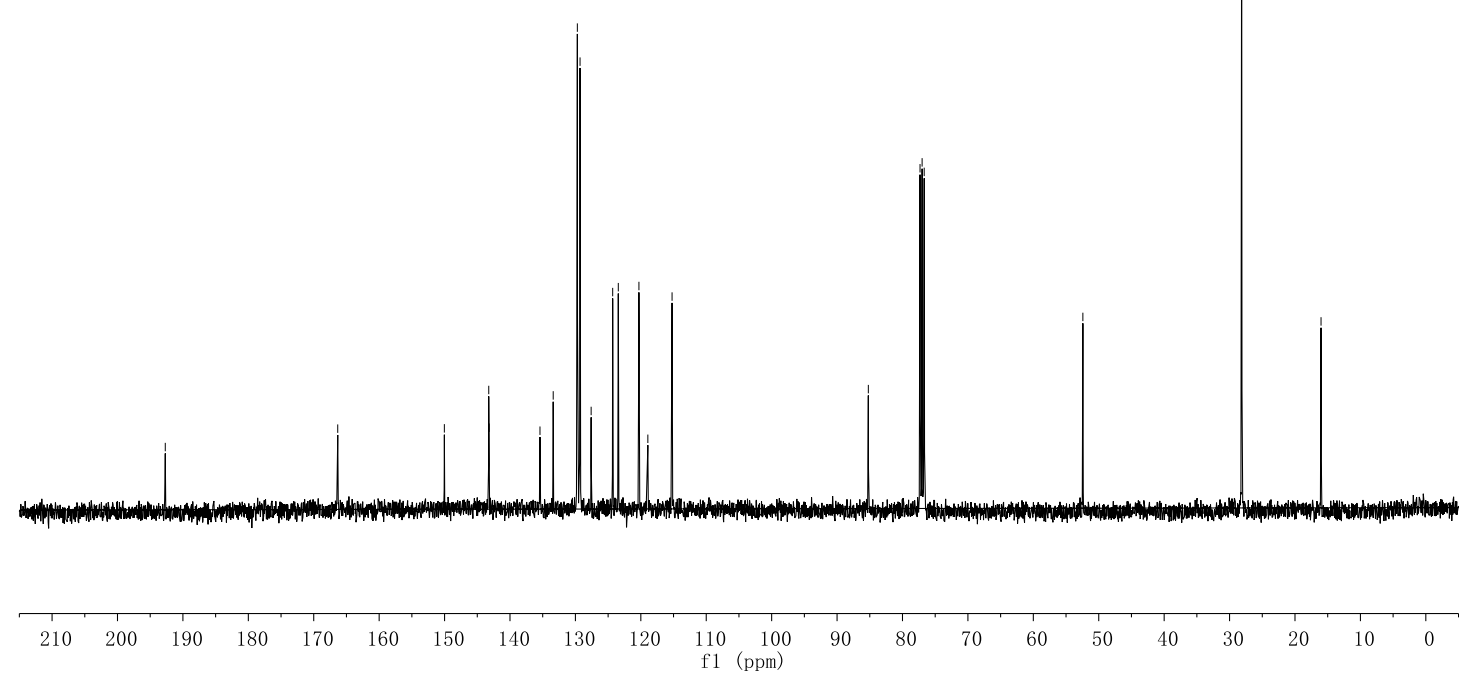




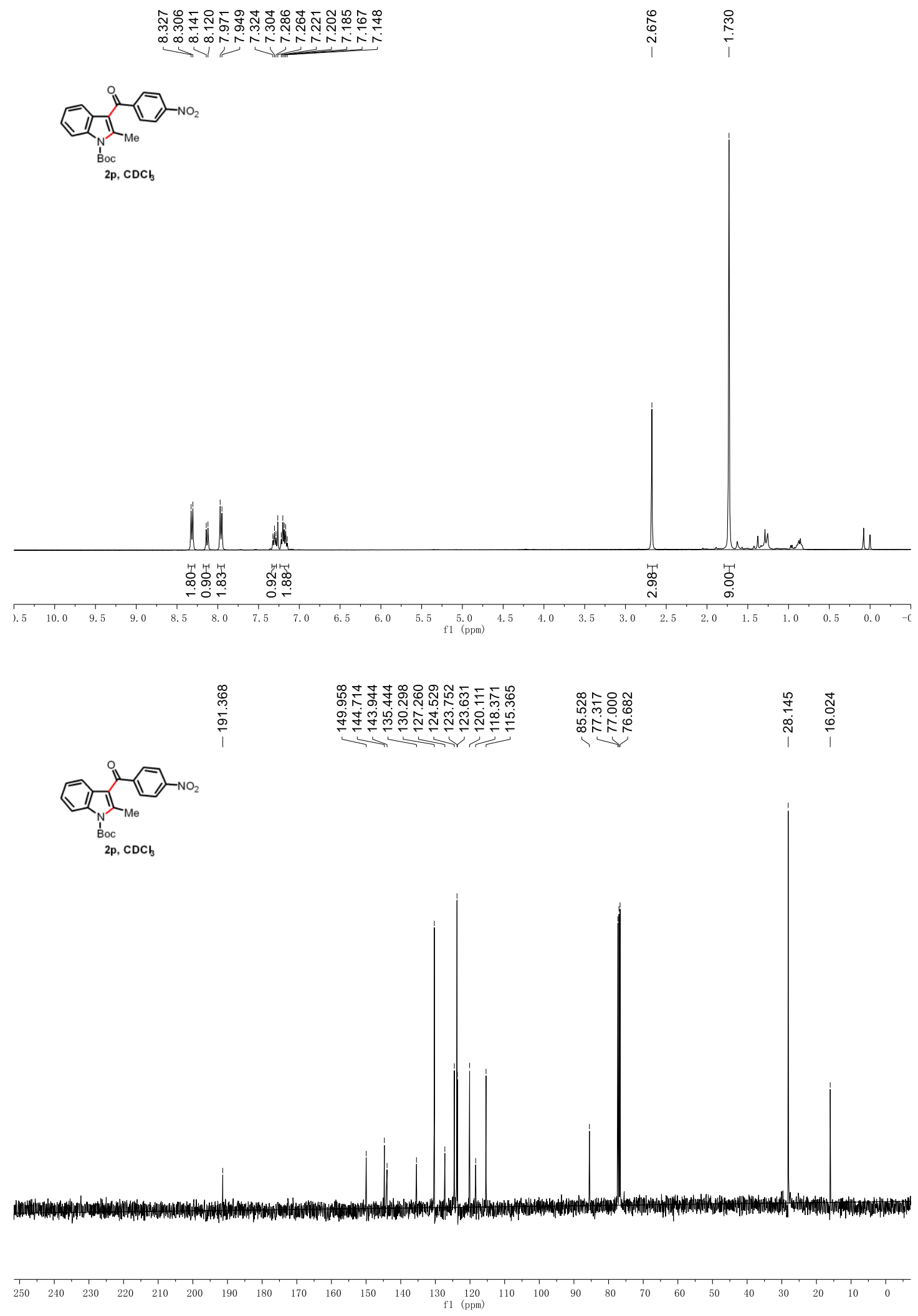




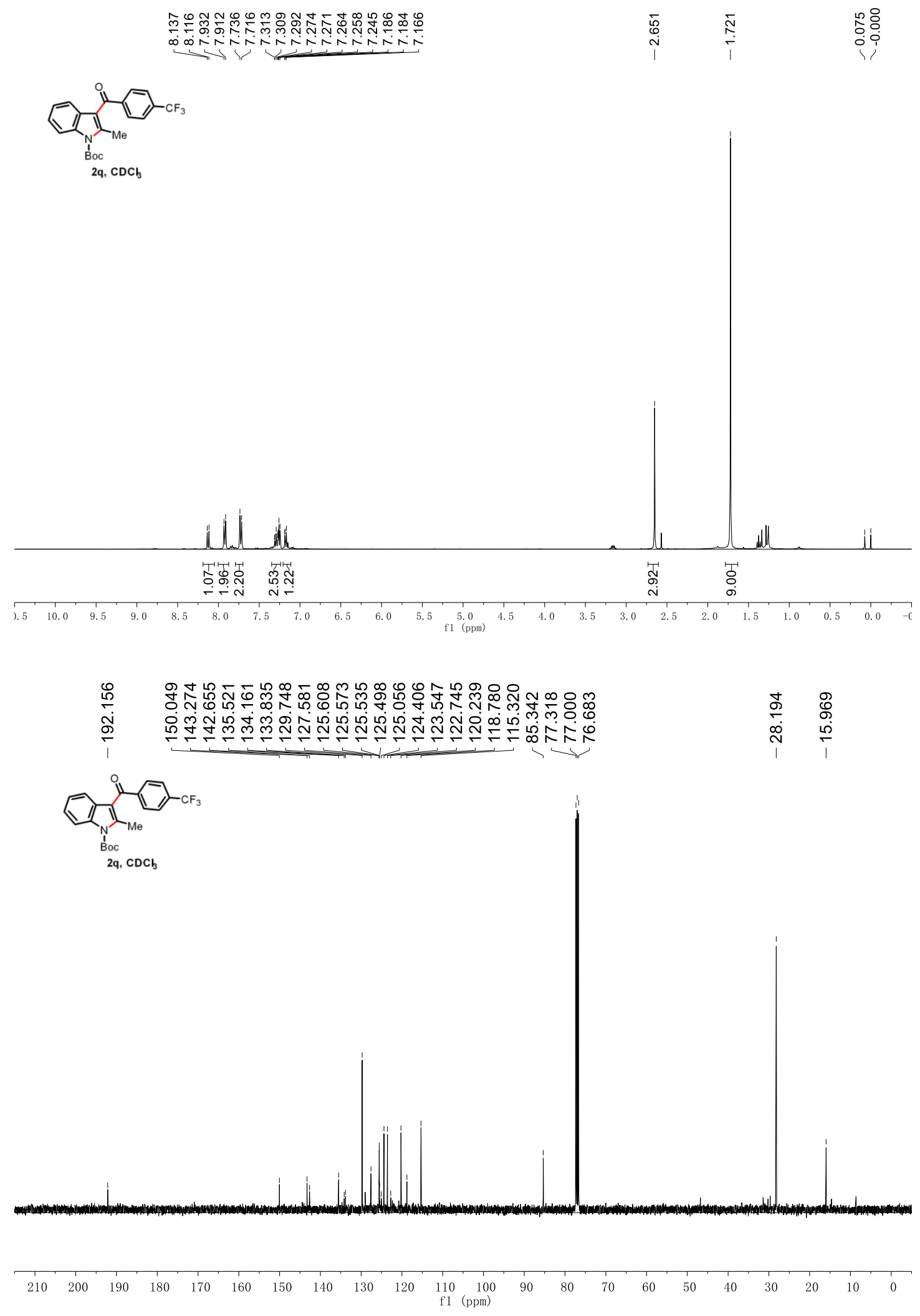



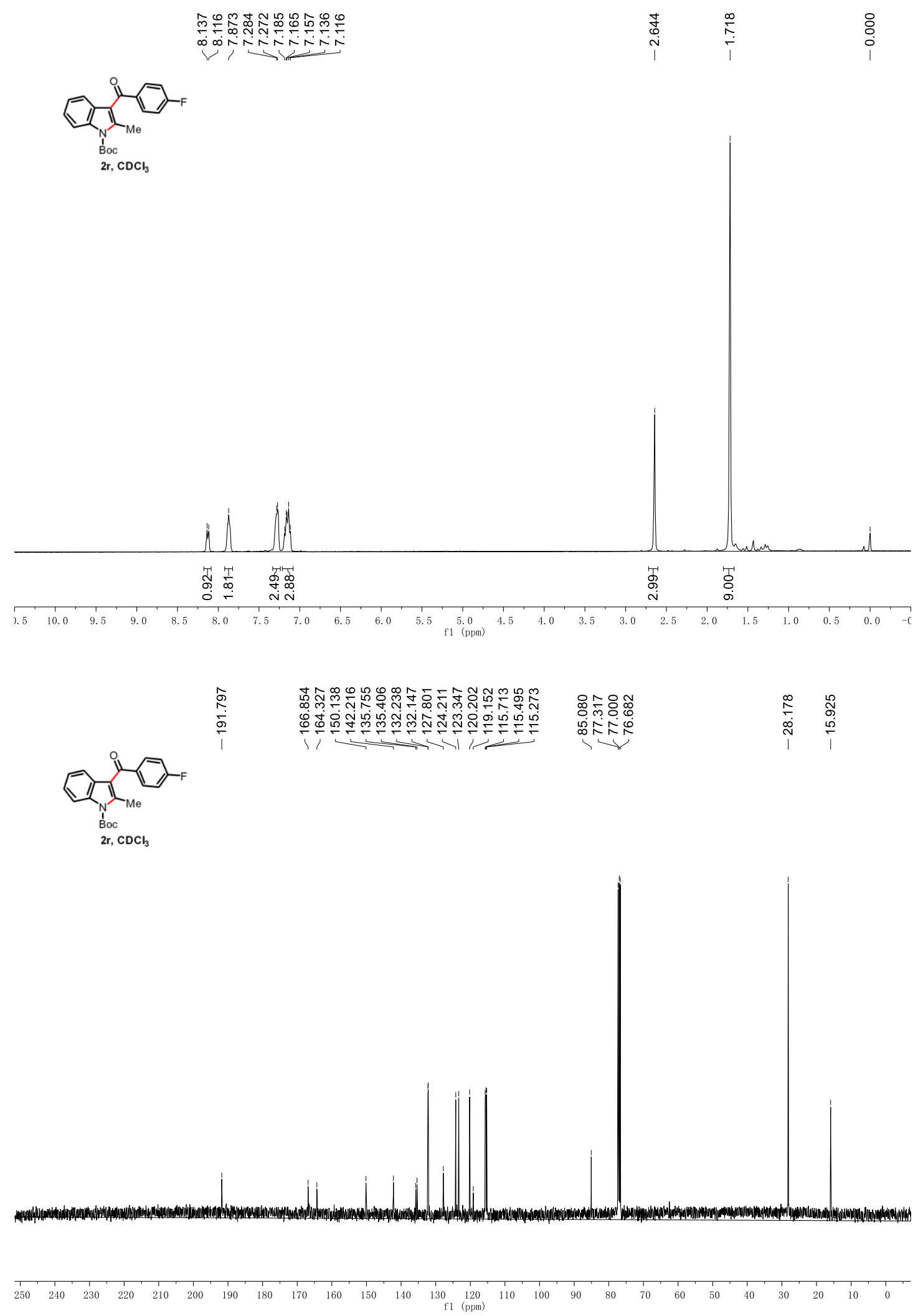


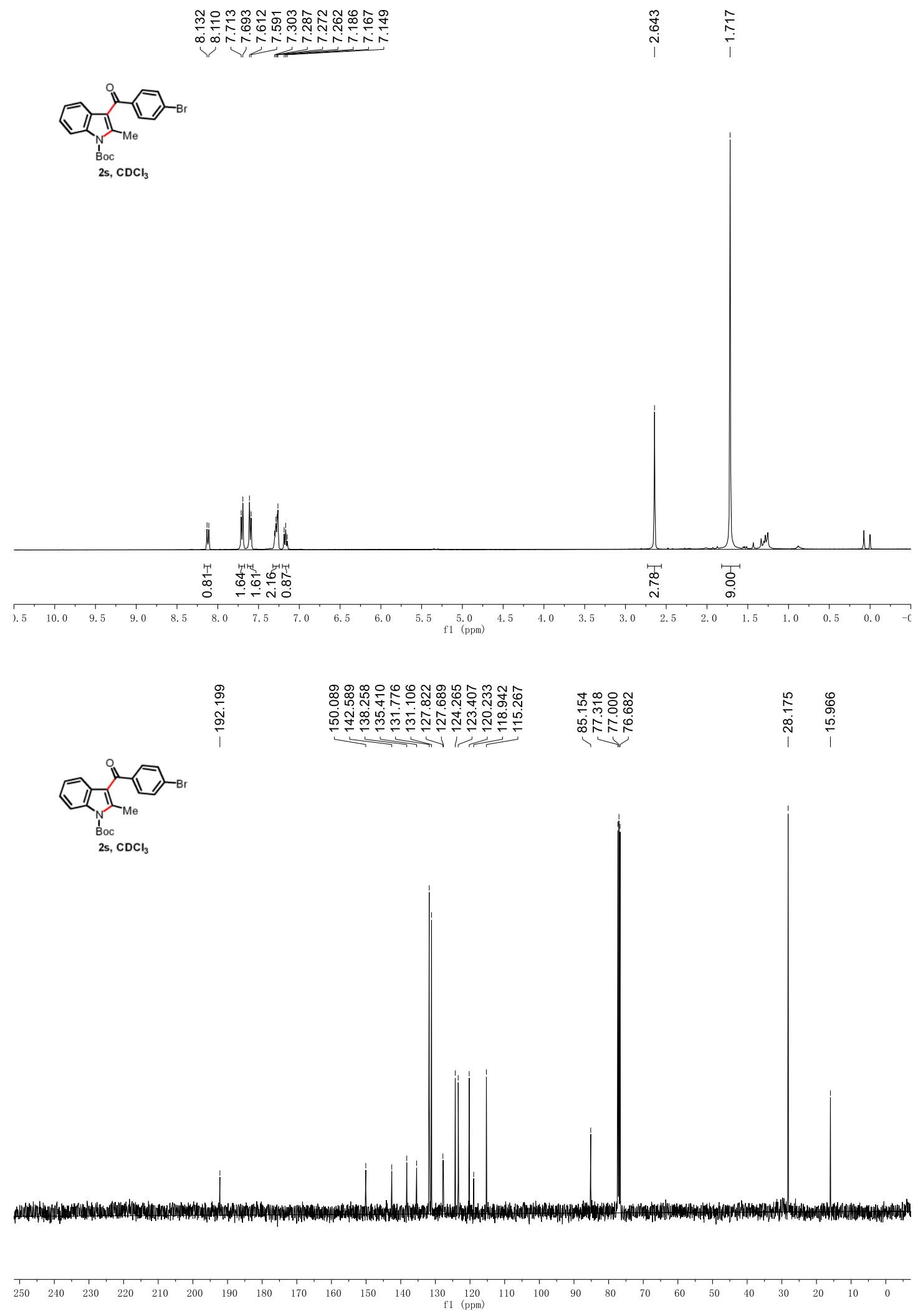




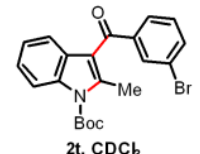

$$
\text { 2t, } \mathrm{CDCl}_{3}
$$
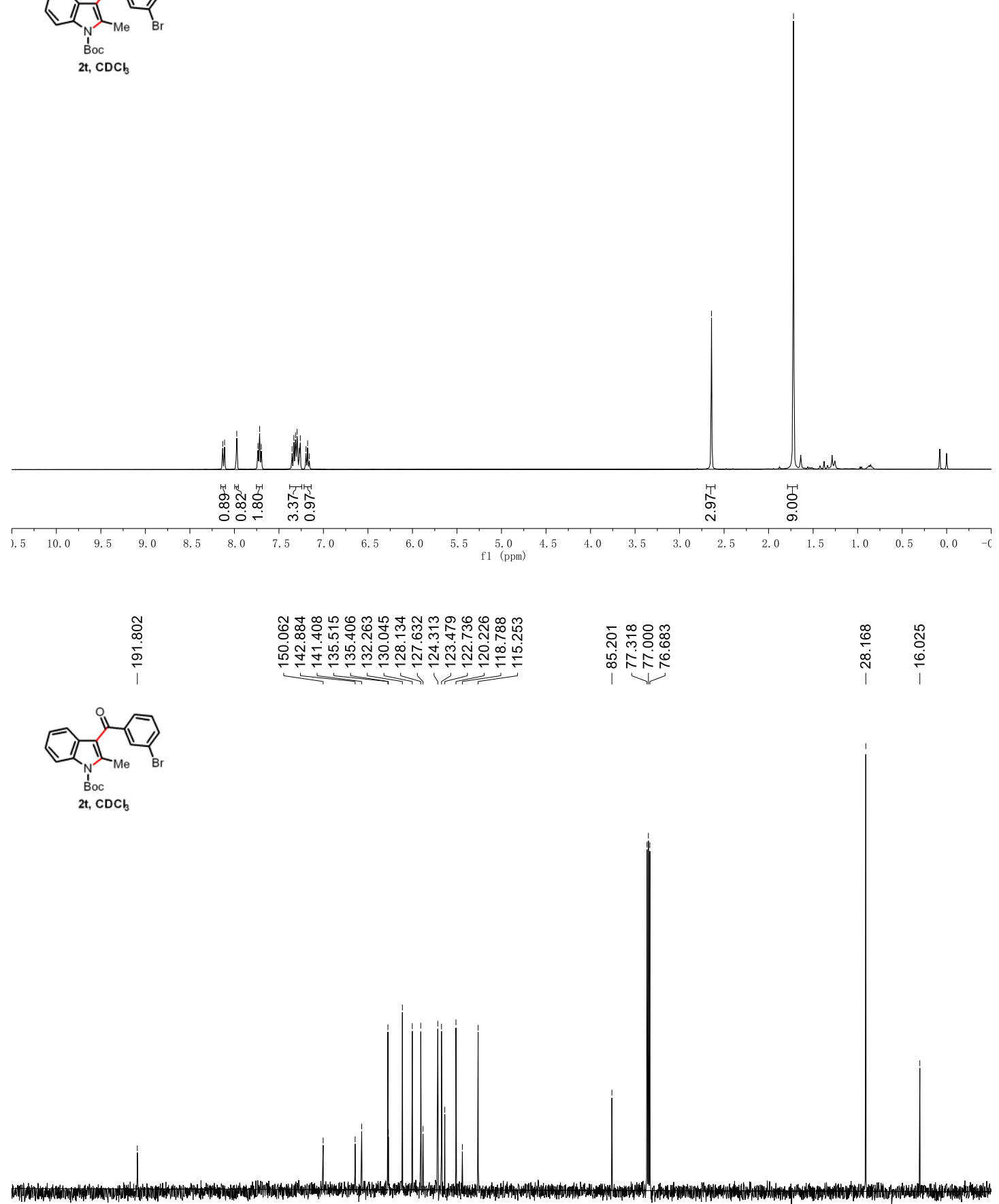

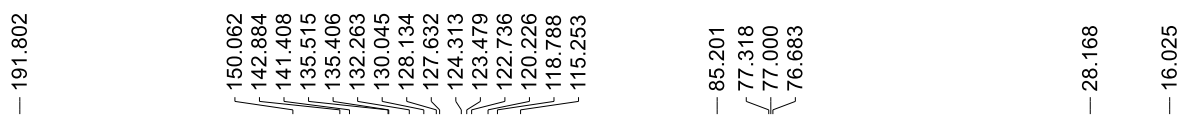

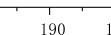

$170 \quad 170$

$150 \quad 140$

$130 \quad 120$

$\stackrel{110}{\mathrm{f} 1}(\mathrm{ppm})$ 


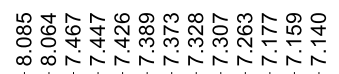

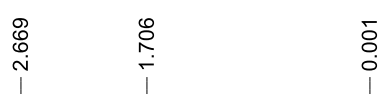

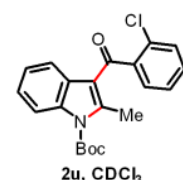

$\mathrm{2u}, \mathrm{CDCl}_{3}$

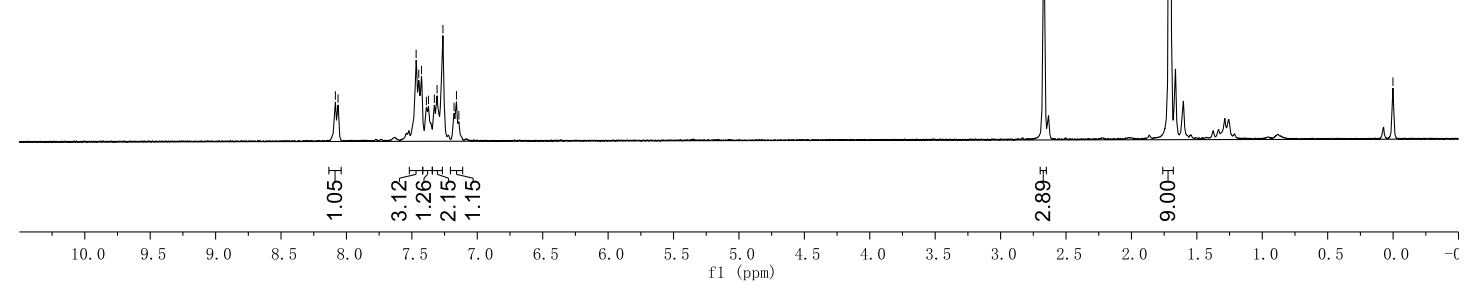

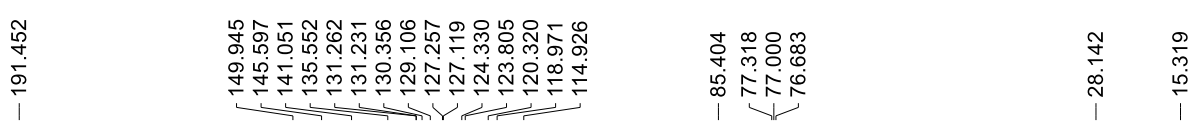
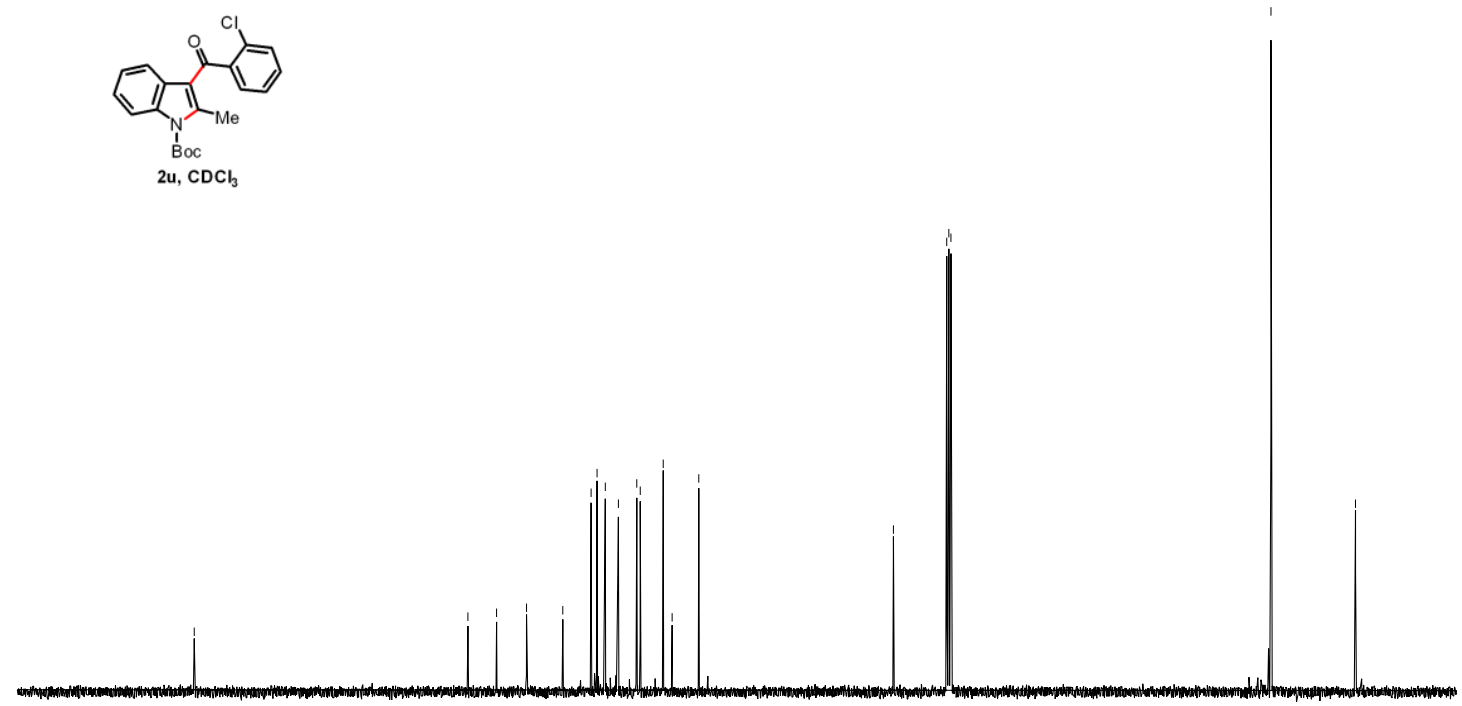

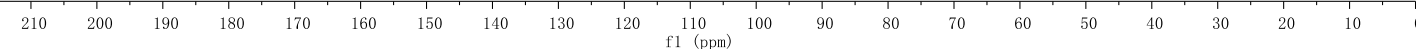



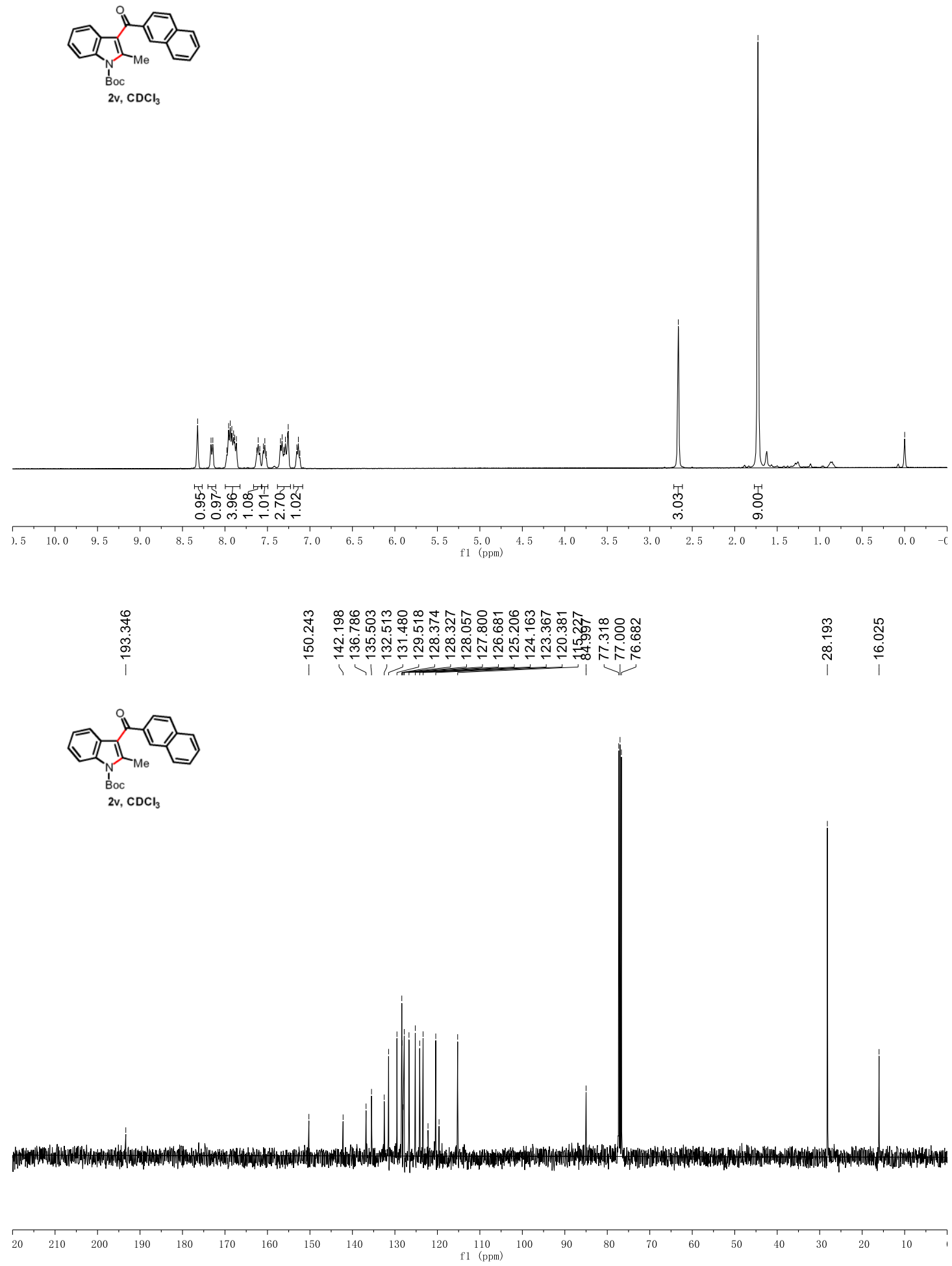


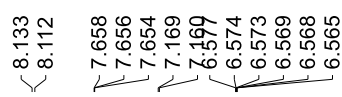

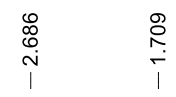
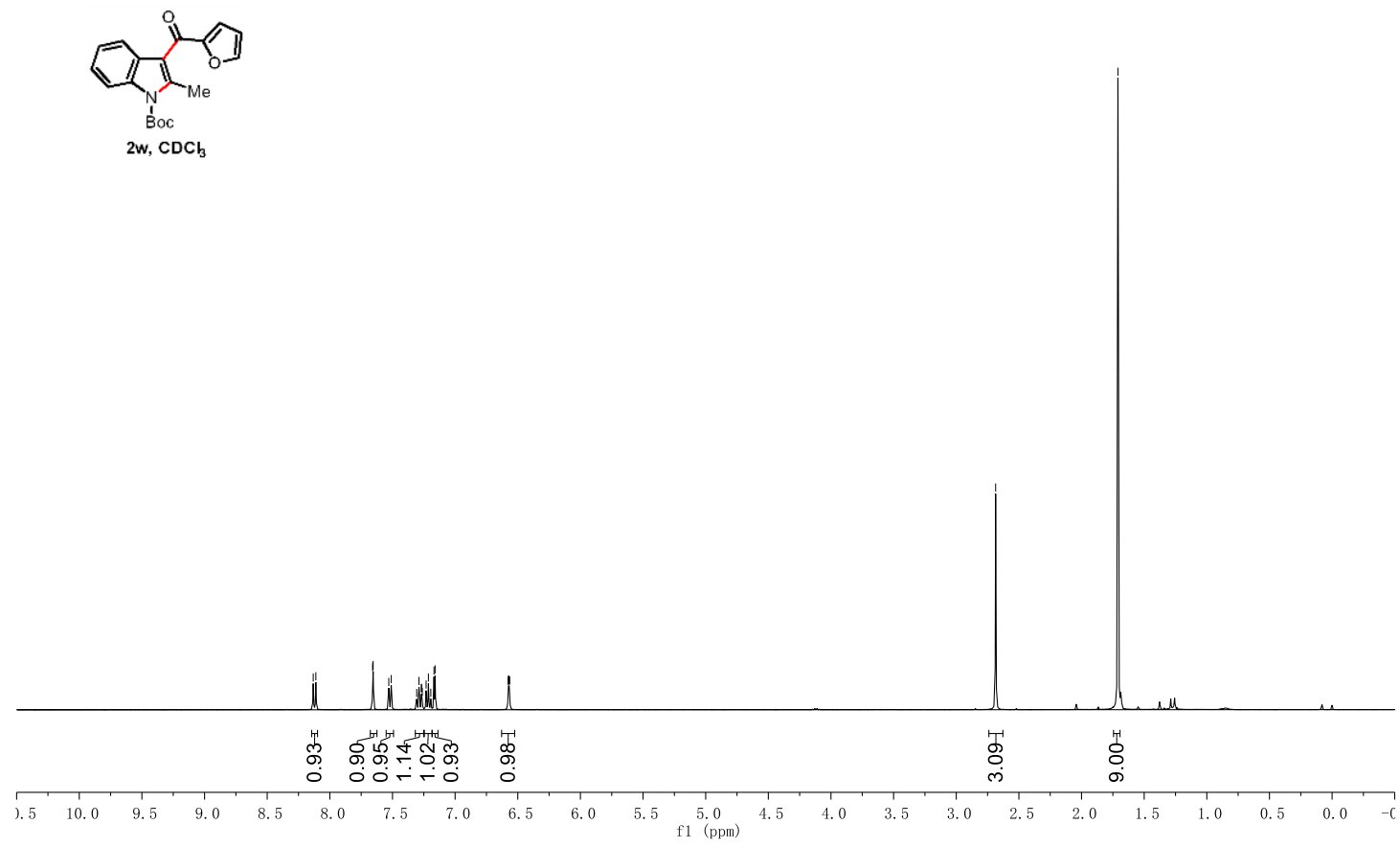

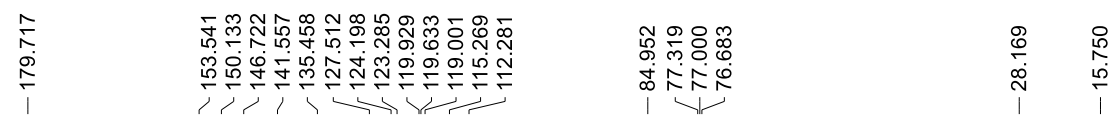
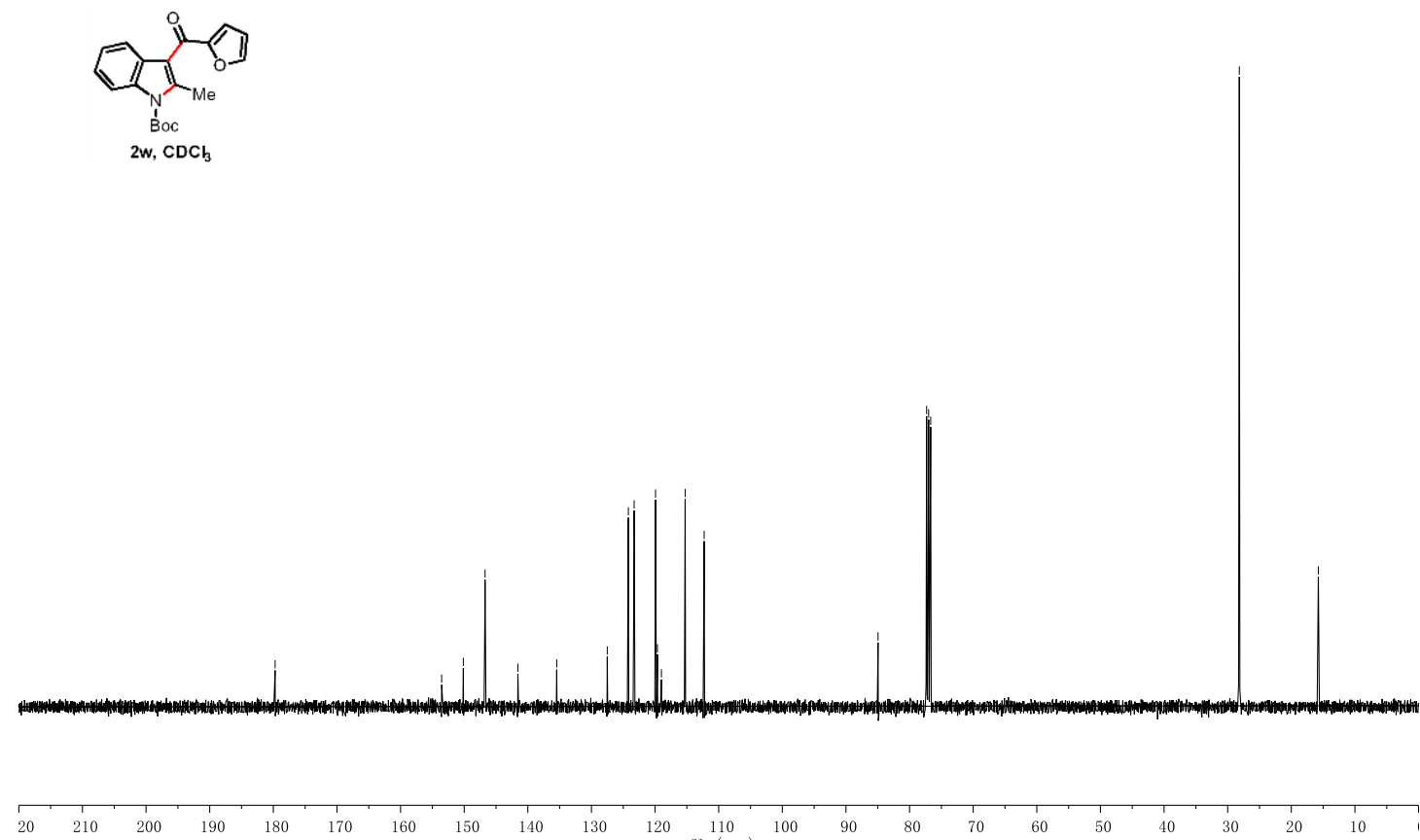

$170 \quad 160$

$150 \quad 140$

$130 \quad 120$

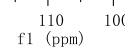




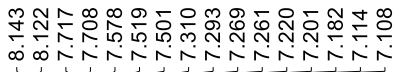

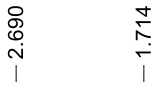
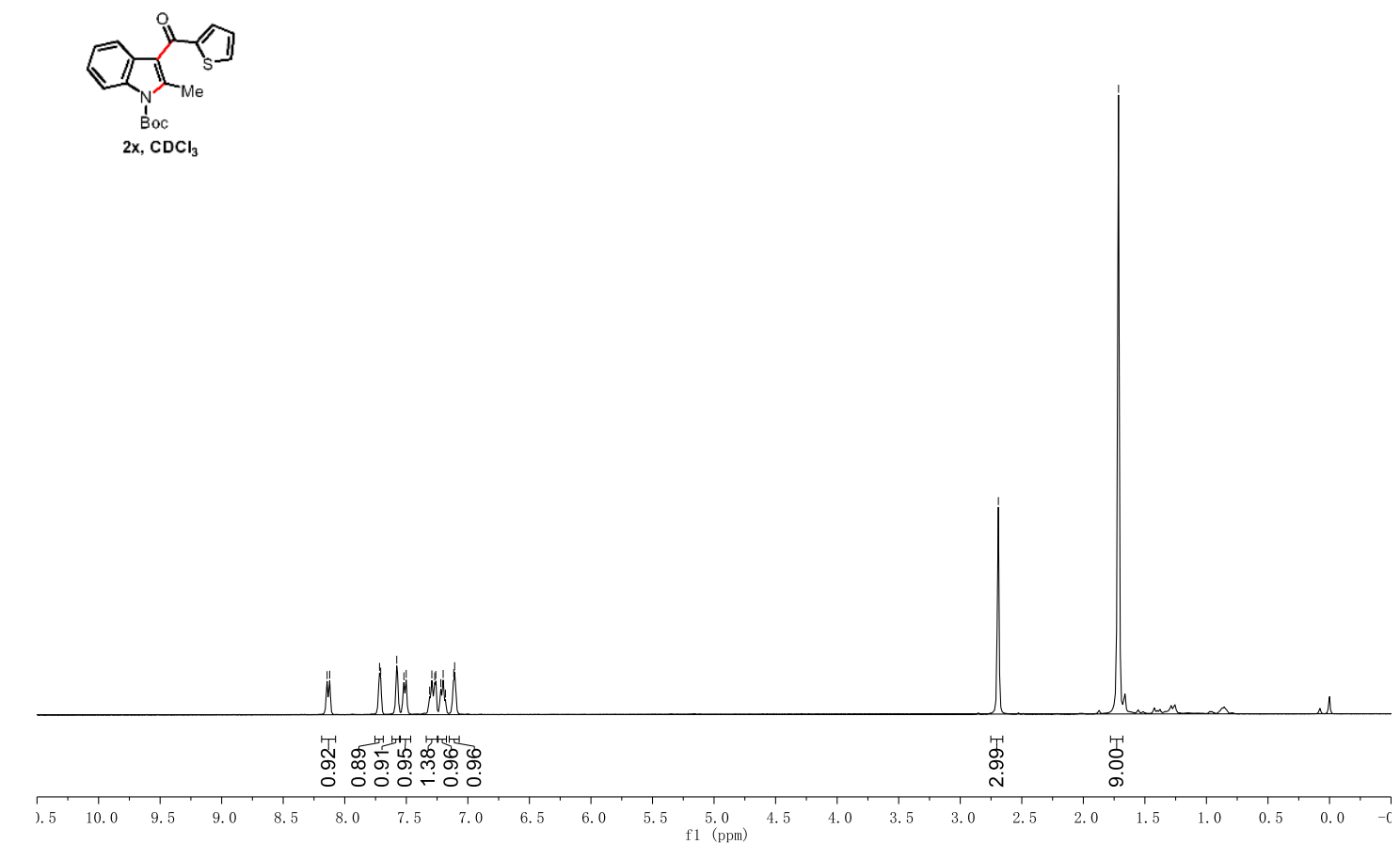

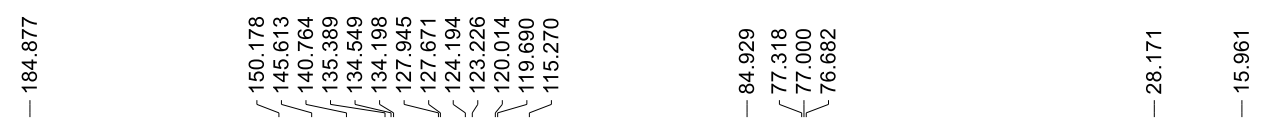

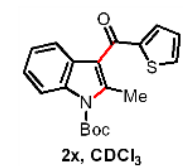

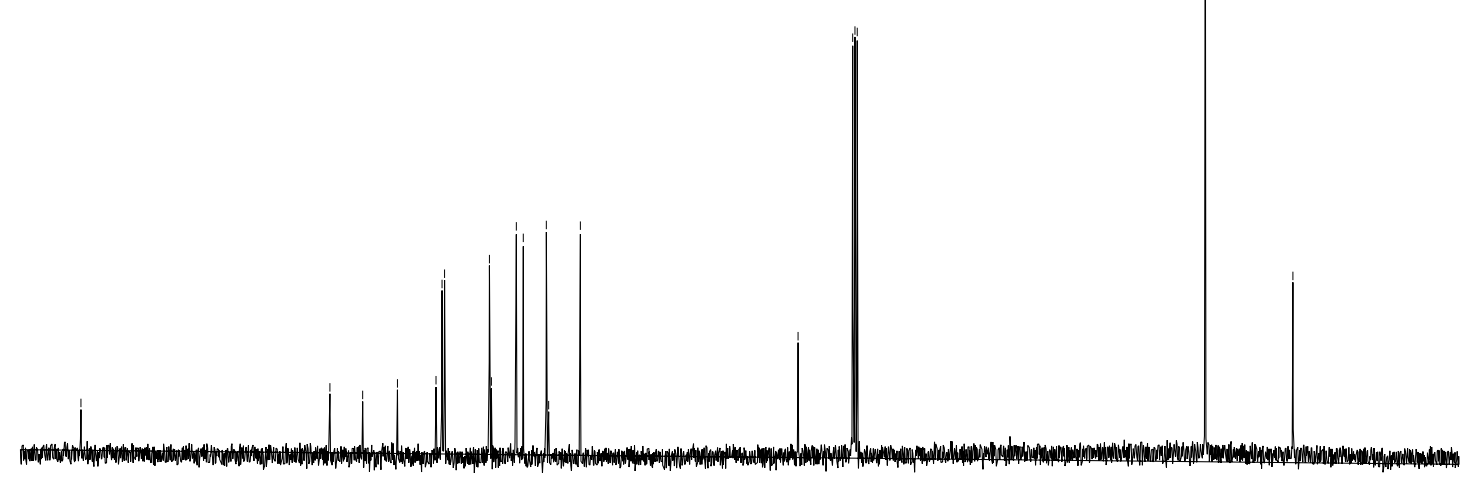

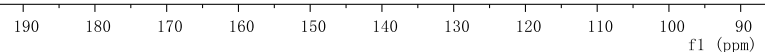




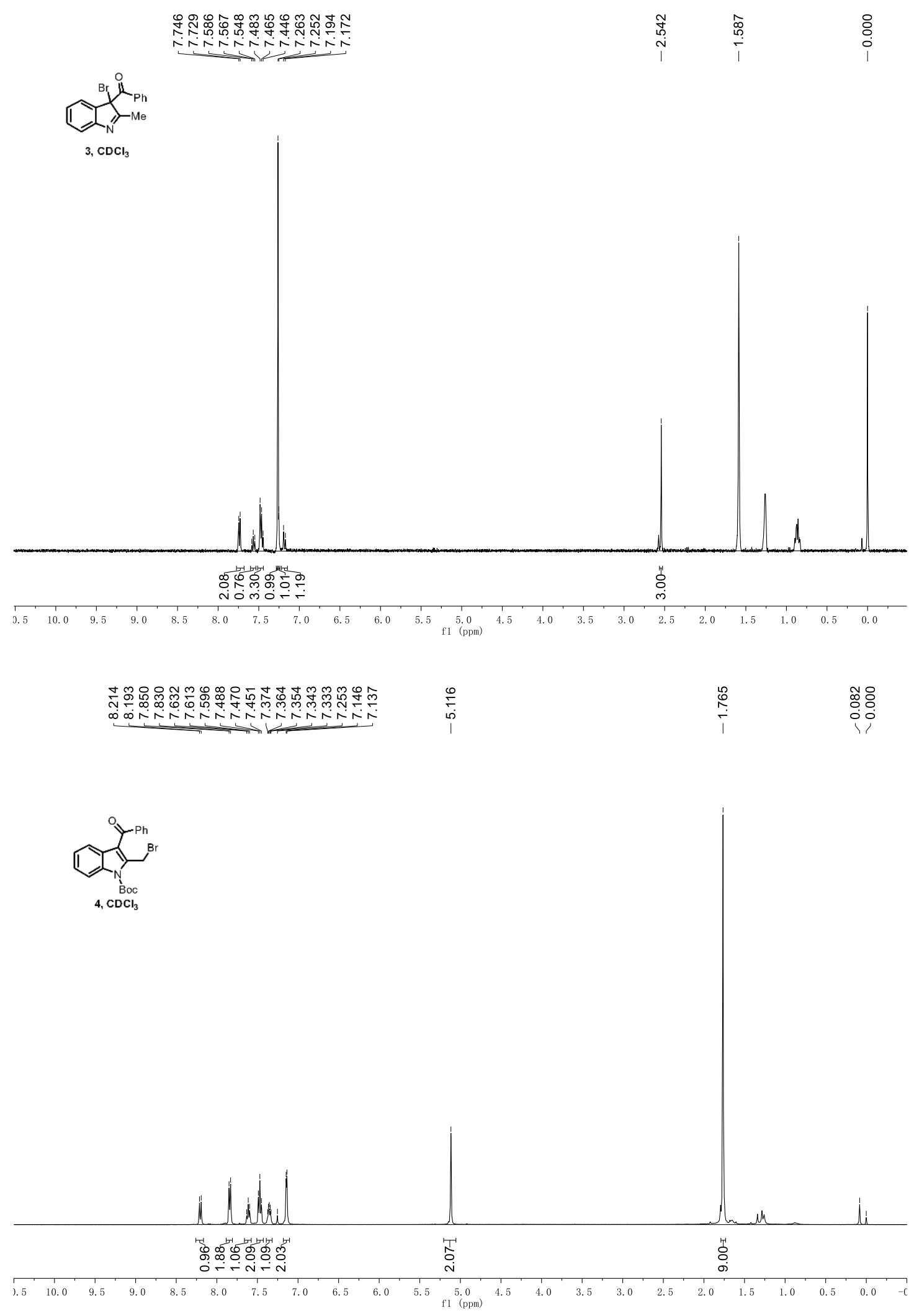




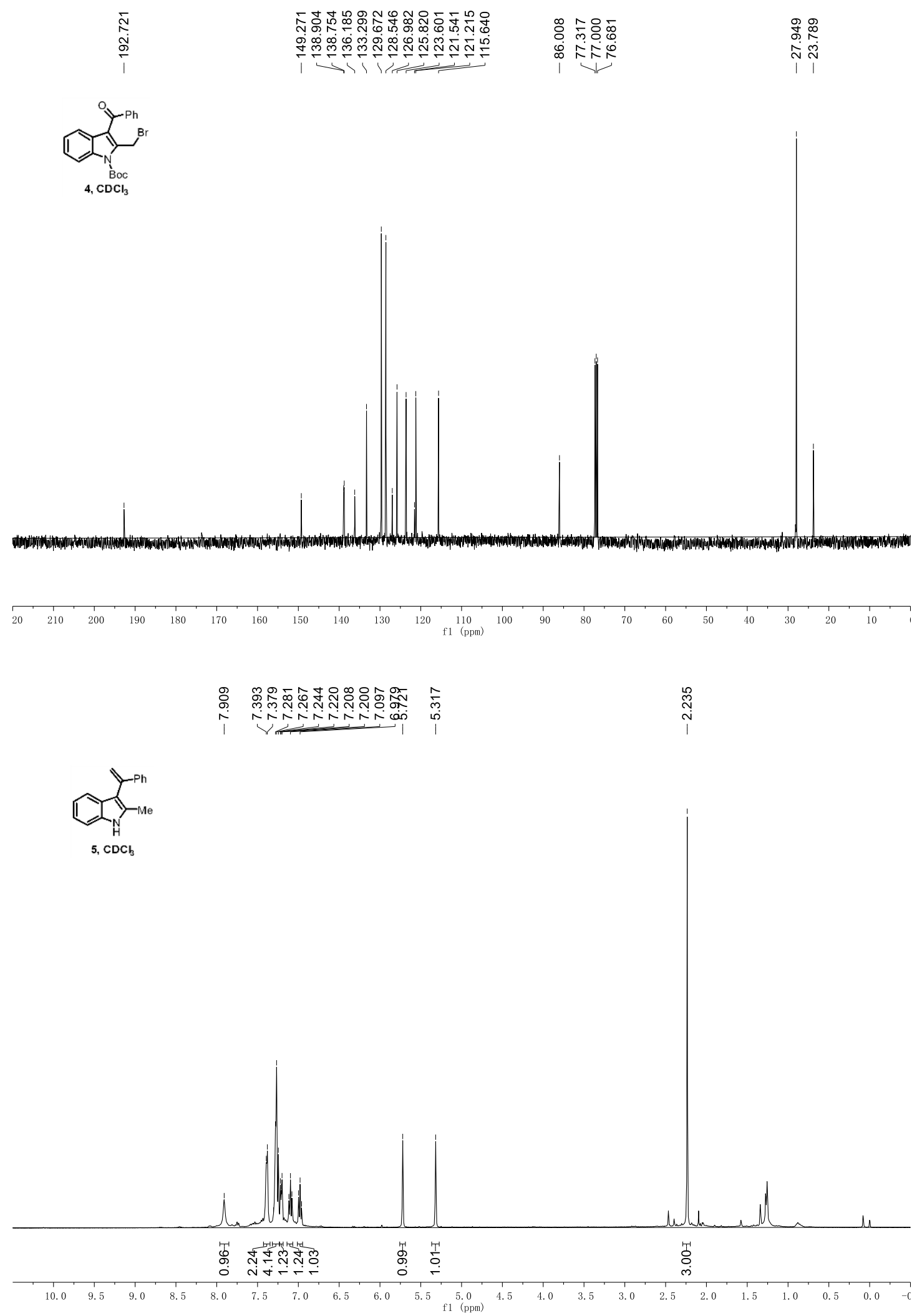




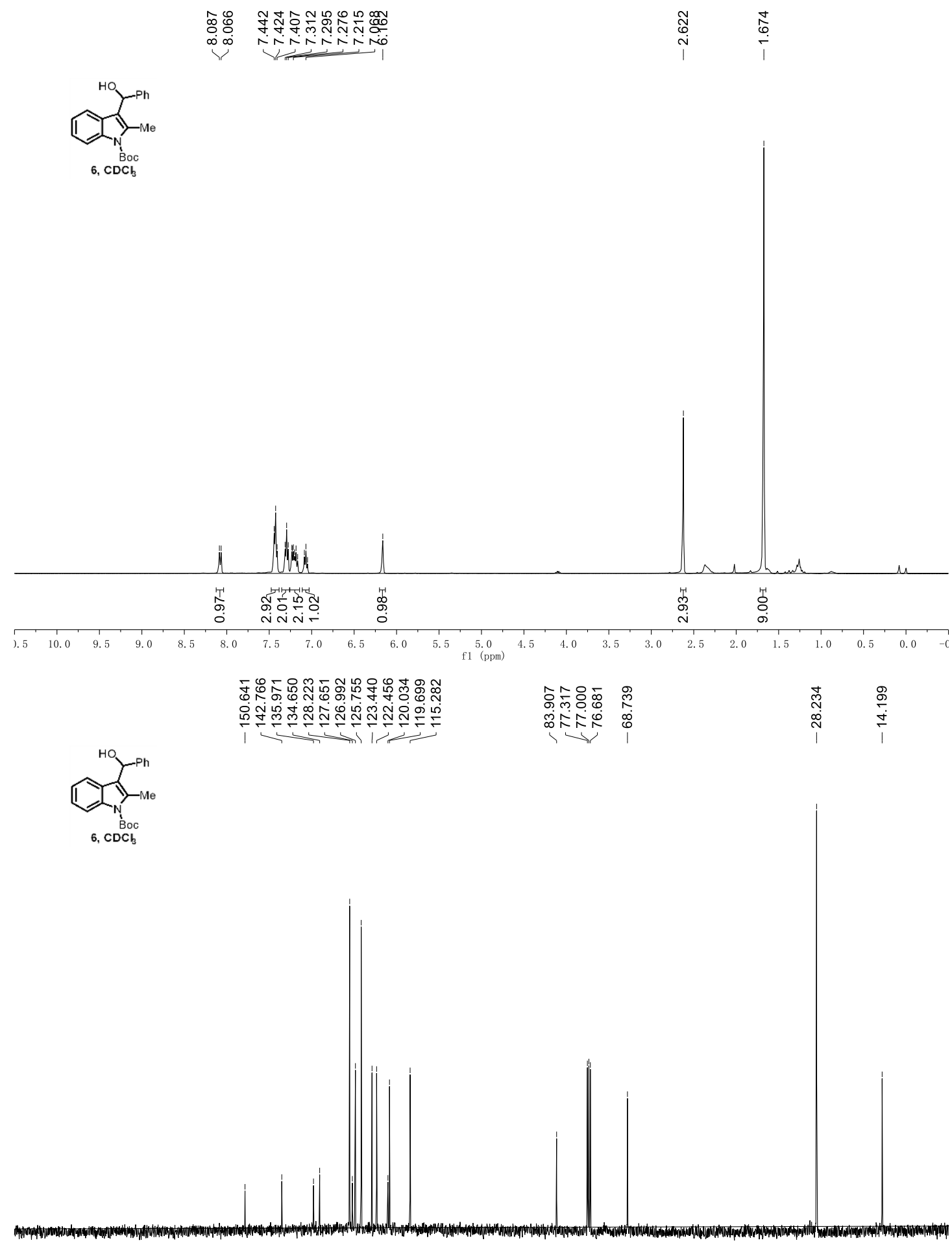

(10.0

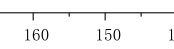

$\begin{array}{lllll}130 & 120 & 110 & 100 \\ \mathrm{f} 1(\mathrm{ppm})\end{array}$ 


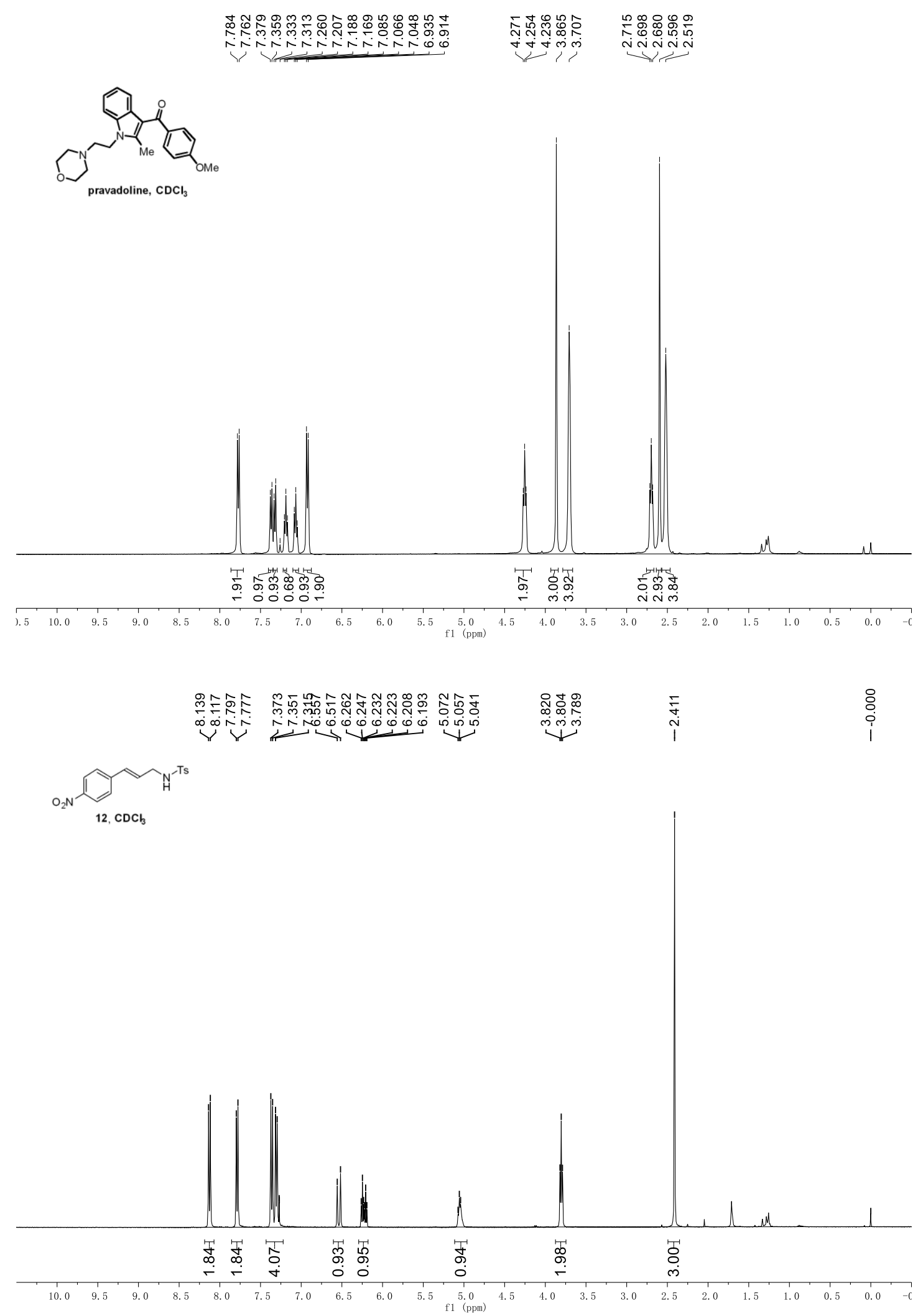



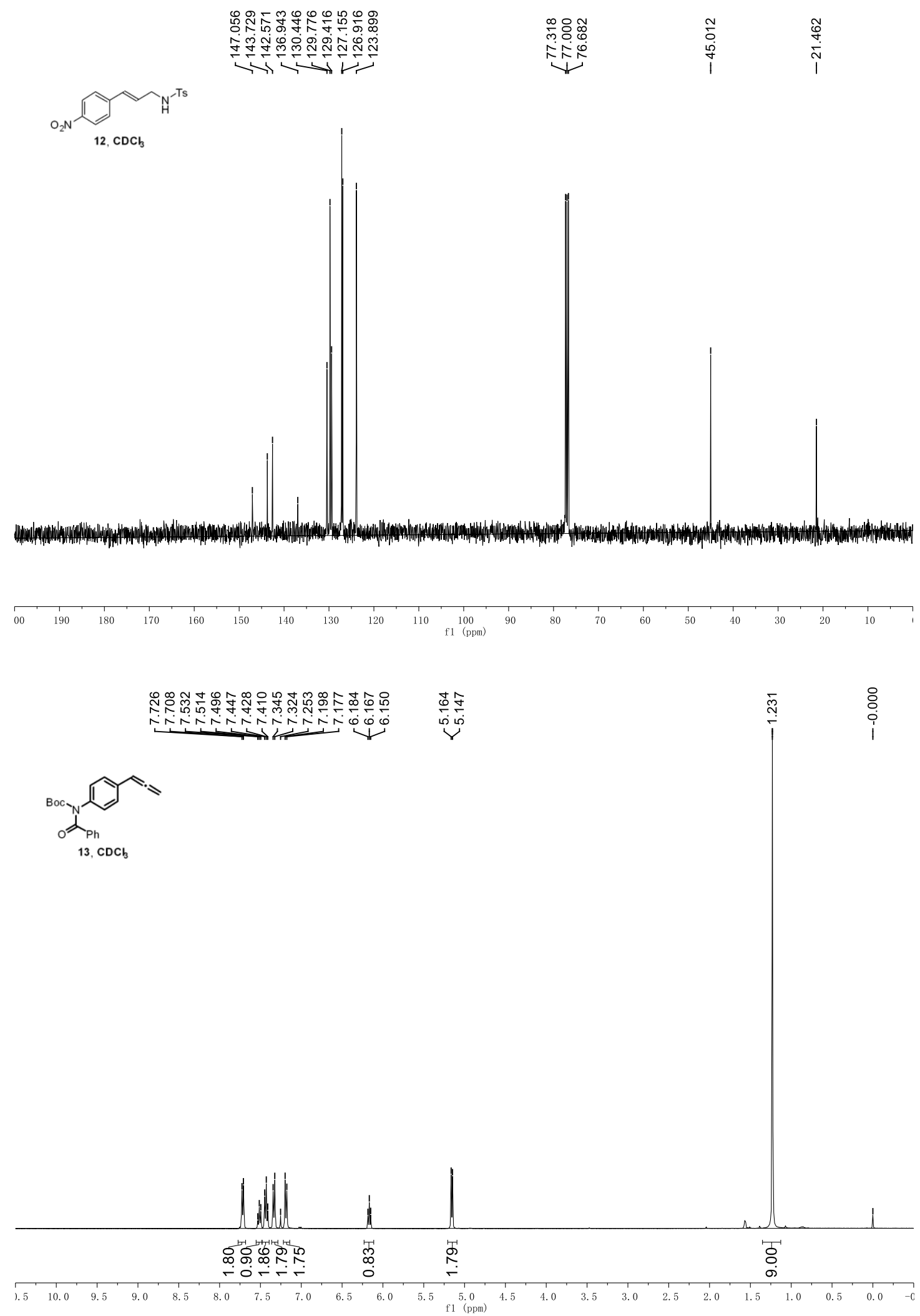


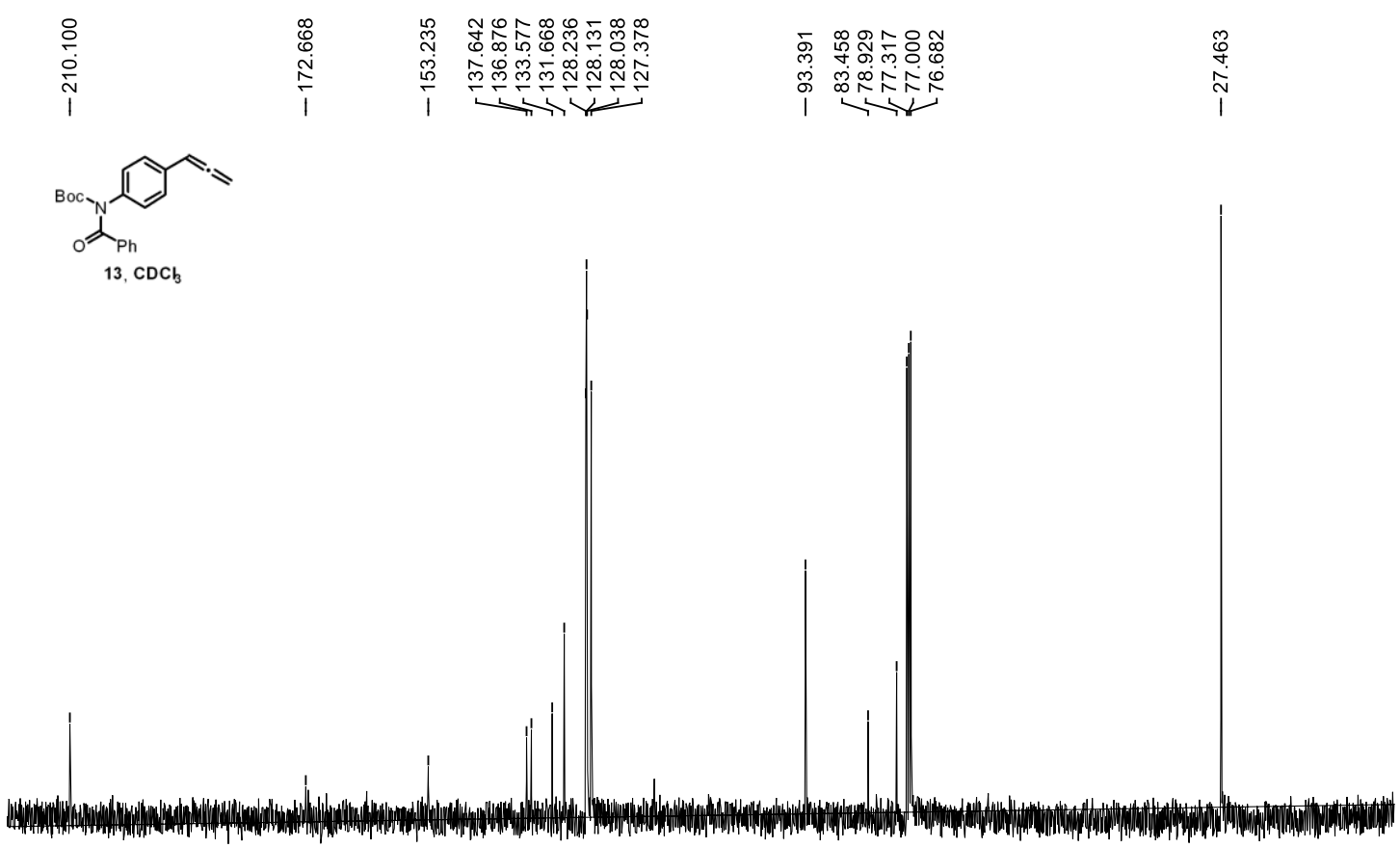

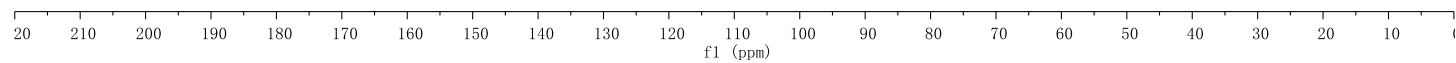

